\title{
Genetic causes of fatal ventricular arrhythmias : the long QT syndrome and familial hypertrophic cardiomyopathy
}

Citation for published version (APA):

Jongbloed, R. J. E. (2003). Genetic causes of fatal ventricular arrhythmias : the long QT syndrome and familial hypertrophic cardiomyopathy. [Doctoral Thesis, Maastricht University]. Universiteit Maastricht. https://doi.org/10.26481/dis.20031001rj

Document status and date:

Published: 01/01/2003

DOI:

10.26481/dis.20031001rj

Document Version:

Publisher's PDF, also known as Version of record

\section{Please check the document version of this publication:}

- A submitted manuscript is the version of the article upon submission and before peer-review. There can be important differences between the submitted version and the official published version of record. People interested in the research are advised to contact the author for the final version of the publication, or visit the DOI to the publisher's website.

- The final author version and the galley proof are versions of the publication after peer review.

- The final published version features the final layout of the paper including the volume, issue and page numbers.

Link to publication

\footnotetext{
General rights rights.

- You may freely distribute the URL identifying the publication in the public portal. please follow below link for the End User Agreement:

www.umlib.nl/taverne-license

Take down policy

If you believe that this document breaches copyright please contact us at:

repository@maastrichtuniversity.nl

providing details and we will investigate your claim.
}

Copyright and moral rights for the publications made accessible in the public portal are retained by the authors and/or other copyright owners and it is a condition of accessing publications that users recognise and abide by the legal requirements associated with these

- Users may download and print one copy of any publication from the public portal for the purpose of private study or research.

- You may not further distribute the material or use it for any profit-making activity or commercial gain

If the publication is distributed under the terms of Article $25 \mathrm{fa}$ of the Dutch Copyright Act, indicated by the "Taverne" license above, 
GENETIC CAUSES OF FATAL VENRTICULAR ARRHYTHMIAS 
(C) Rosaline JE Jongbloed, Maastricht 2003

ISBN 90-9017134-7

Omslag illustratie: Graphics adapted from St Luke's-Roosevelt Hospital with permission Vormgeving en druk: Datawyse/ Universitaire Pers Maastricht 


\section{GENETIC CAUSES OF FATAL VENTRICULAR ARRHYTHMIAS}

the long QT syndrome and familial hypertrophic cardiomyopathy

\section{Proefschrift}

ter verkrijging van de graad van doctor

aan de Universiteit Maastricht,

op gezag van de Rector Magnificus,

Prof. dr. A. C. Nieuwenhuijzen Kruseman

volgens het besluit van het College van Decanen,

in het openbaar te verdedigen

op woensdag 01 oktober 2003 om 14.00 uur

door

Rosaline José Elly Jongbloed

geboren te Heerlen 


\section{Promotor}

Prof. dr. J. P. M. Geraedts

\section{Co-promotores}

Dr. H. J. M. Smeets

Dr. P. A. F. M. Doevendans

\section{Beoordelingscommissie/Committee of assessment}

Prof. dr. H. A. J. Struijker Boudier (voorzitter)

Dr. A. P. M. Gorgels

Prof. dr. R. N. W. Hauer (Universiteit Utrecht)

Dr. M. M. A. M. Mannens (Universiteit van Amsterdam)

Prof. dr. R. F. M. Vlietinck

Publication of this thesis was financially supported by the Stichting Klinische Genetica Zuid-Oost Nederland (SKGZON)

Financial support by the Netherlands Heart Foundation for the publication of this thesis is gratefully acknowledged 
"zoekt en gij zult vinden"
Matteüs 



\section{Contents}

\section{Chapter 1 Introduction}

Arrhythmia \& Inherited Cardiac Diseases

Aims of the study

Chapter 2 The Long QT syndrome

Chapter 3 Genetic background in LQTS patients

Novel KCNQ1 and HERG missense mutations in Dutch Long-QT families

Chapter 4 Genetic analysis of LQTS related genes

DHPLC Analysis of Potassium lon Channel Genes in Congenital Long QT Syndrome

\section{Chapter 5 Gene specific triggers in LQTS}

5-1 Auditory stimuli as a trigger for arrhythmic events differentiate HERG related (LQTS2) patients from KvLQT1-related patients (LQTS1)

5-2 Gene specific distribution of cardiac events in LQTS1 and LQTS2

\section{Chapter 6 Effect of medical treatment in genotyped LQTS patients}

Gender differences in the long QT syndrome: effects of $\beta$-adrenoceptor blockade

Chapter 7 Familial Hypertrophic Cardiomyopathy

Chapter 8 Genotype-phenotype correlation in FHC

8-1 Efficient screening of the MYH7 gene in Familial Hypertrophic Cardiomyopathy associated with Sudden Cardiac Death

8-2 Variable clinical manifestation of a novel missense mutation in the alpha-Tropomyosin (TPM1) gene in Familial Hypertrophic Cardiomyopathy

Chapter 9 General Discussion

Summary

Samenvatting

Dankwoord

Curriculum vitae

Publications 

1

INTRODUCTION 


\section{Cardiac arrhythmia}

Sequential contraction of the heart provides adequate blood supply in all parts of the human body. This contraction is regulated by synchronized electric activation generated by the specific architecture and composition of the cardiac conduction system, and by the properties of the cardiac myocytes which are constructed to generate and transmit force. Uncoordinated contraction of the heart, due to abnormal heart rhythms (arrhythmia / dysrhythmia) or due to conduction defects, may lead to clinical symptoms as seizures, syncope or sudden cardiac death. Cardiac arrhythmias account for more than $10 \%$ of all natural death [1]. They can be divided in two major groups: tachycardia (too fast heart rate) and bradycardia (too slow heart rate). Arrhythmias can originate in the sinoatrial (SA) node, atria, atrioventricular (AV) node, His-Purkinje system, and ventricles. Except for the last two, they are grouped as supraventricular arrhythmias, because they originate above the ventricles. Arrhythmias which originate in the His-Purkinje system or ventricles are described as ventricular arrhythmias. Depending on their origin in the heart, cardiac rhythm disturbances or fibrillation can be divided in atrial and ventricular fibrillation. While atrial fibrillation is not dangerous though difficult to treat, ventricular fibrillation is most serious and can be the cause of sudden death and has to be treated by electrical shock therapy. During the last decade many researcher have focussed on uncovering the mechanism and etiology of the various forms of familial ventricular fibrillation. The arrhythmias described in this thesis are inherited forms of ventricular fibrillation (VF) and ventricular tachycardia (VT), caused by electrical disturbances or electric instability in the heart.

In 2002 it was exactly 100 years ago that the Dutch professor Einthoven, a physiologist at the University of Leiden reported the recordings of the human electrocardiogram with the string galvanometer in a festschrift to Professor S. Rosenstein entitled "Galvanometrische registratie van het menschelijk electrocardiogram" [2]. Hundred years later we are beginning to understand which proteins and genes are involved in (ab)normal human electrocardiographic (ECG) recordings. These ECG recordings are a valuable tool for physicians and have become a hallmark for clinical diagnosis and treatment of cardiac diseases like congenital Long QT syndrome (LQTS) and familial hypertrophic cardiomyopathy (FHC). Although the etiology of the inherited cardiac disorders LQTS and HCM is different, both present with similar clinical features like cardiac arrhythmia and sudden cardiac death at a young age.

In 1992, the Department of Genetics and Cellbiology of the University of Maastricht and the Department of Cardiology of the Academic Hospital in Maastricht, initiated a program to identify the genetic basis of LQTS and other unexplained arrhythmogenic disorders, in particular hypertrophic cardiomyopathy (HCM), dilated cardiomyopathy (DCM) and arrhythmogenic right ventricular dysplasia (ARVD or ARVC). At that time 
only one gene, the cardiac beta-myosin heavy chain gene, located on chromosome 14924, had been shown to be involved in the autosomal dominant form of HCM [3] and no genes were identified yet for LQTS, DCM or ARVD. Since then, numerous genes have been identified while 10 sarcomeric genes have been associated with HCM thereby classifying this disorder as "sarcomeropathy".

The initial breakthrough for genetic analysis of LQTS came in 1995, when within 9 months (between March 1995 and January 1996), mutations in three genes encoding potassium- and sodium ion channels were reported as disease causing defects in families with LQTS $[4,5]$. Initially, two genes, encoding a cardiac potassium channel on chromosome $7 q 35$ and a cardiac sodium channel on chromosome $3 p 21$, were identified by using a candidate gene approach while the third ion channel gene finally could be identified on chromosome 11p15.5 by positional cloning [6]. Based on the similar function of the LQTS gene products, the disorder has been classified as a "channelopathy".

Today, the DNA laboratory of the Department of Clinical Genetics of the Academic Hospital Maastricht is one of the two leading centers in the Netherlands that are specialized in diagnostic genetic analysis in families with LQTS, HCM and other inherited cardiac diseases. Genetic testing allows confirmation of the diagnosis of a farrilirai 'neart daisease. in these tamilies individuals at risk can be genotyped and carriership can be unequivocally identified. Subsequent follow-up studies of carriers enables the determination of genotype-phenotype relations which can be used for predicting possible clinical manifestations of asymptomatic carriers. Today, genetic analysis has become extremely useful for clinicians to select individuals, being at risk of sudden cardiac death, for aggressive treatment. In these individuals, who may be asymptomatic at the time of investigation, the prophylactic use of anti-arrhythmic agents should be considered. This thesis covers the molecular genetic background of two distinct familial cardiac diseases LQTS and HCM, the genetic and phenotypic complexity and the development of a protocol for diagnostic DNA testing. The arrhythmias caused by defective ion channels, within a morphological and histological normal heart, are described in the section on "the Long QT Syndrome (LQTS)", whereas arrhythmias as part of a disease complex, dominated by morphological changes in the heart, are described in the section on "Familial Hypertrophic Cardiomyopathy (FHC)".

\section{The aims of this thesis were}

A) To resolve the genetic basis for two cardiac diseases LQTS and FHC, associated with arrhythmia and sudden death in young individuals. The genetic basis will be outlined in Chapter 2 for LQTS and in Chapter 7 for FHC. 
B) To investigate the prevalence of the genetic defects in families diagnosed with LQTS or FHC. The results are integrated with the results of the chapters referred under section $\mathrm{A}$.

C) To correlate the genetic defect with a gene-specific phenotype (Chapters 3 and 5) and pharmacological treatment (Chapter 6). These data were compared with data from literature. This has been predominantly done for LQTS and has led to a gene directed screening protocol.

\section{References}

1. Ackerman MJ. The long QT syndrome: ion channel disease of the heart. Mayo Clin Proc. 1998;73:250-69.

2. Einthoven W. Galvanometrische registratie van het menschelijk electrocardiogram. In: Herinneringsbundel prof. S. S. Rosenstein. Leiden: Eduard Udo. 1902;101-106.

3. Geisterfer-Lowance AAT, Kass S, Tanigawa G, et al. A molecular basis for familial hypertrophic cardiomyopathy: a B cardiac myosin heavy chain gene missense mutation. Cell. 1990;62:999-1006.

4. Curran ME, Splawski I, Timothy KW, Vincent GM, Green ED, Keating MT. A molecular basis for cariac arrhythmia: HERG mutations cause long QT syndrome. Cell. 1995;80:795-803.

5. Wang Q Shen J, Splawski I, Atkinson D, Li Zhizhong, Robinson IL, Moss AJ, Towbin JA, Keating MT. SCN5A mutations associated with an inherited cardiac arrhythmia, long QT syndrome. Cell. 1995;80:805-811.

6. Wang Q Curran ME, Splawski I, Burn TC, Millholland JM, VanRaay TJ, Shen J, Timothy KW, Vincent GM, de Jager T, Schwartz PJ, Towbin JA, Moss AJ, Atkinson DL, Landes GM, Connors TD, Keating MT. Positional cloning of a novel potassium channel gene: KVLQT1 mutations cause cardiac arrhythmias. Nat Genet. 1996;12:17-23. 



\section{2}

THE LONG QT SYNDROME 


\section{THE LONG QT SYNDROME}

The Long QT syndrome (LQTS) has been referred to as Romano-Ward syndrome, as it has been described independently in 1963 and 1964 by the cardiologists Romano and Ward $[1,2]$. They both reported a specific congenital arrhythmia with a history of sudden death in young and apparently healthy children. LQTS associated with bilateral deafness, is referred to as Jervell and Lange-Nielsen syndrome, after an initial description of the disease by Jervell and Lange-Nielsen in 1957 [3]. Actually the JLNS was already described by Meissner et al in 1856, who reported the collaps and sudden death of a deaf girl, while two of her brothers died after a terrible fright and violent rage [4]. The first electrographic registration of LQTS has been reported by Herrlin and Möller in 1953 [5].

\section{2-1 Clinical features of Long QT Syndrome}

Syncope and seizures are the main clinical features of LQTS, which result directly from cardiac arrhythmia and circulatory arrest. These arrhythmias can be triggered by adrenergic stimuli such as physical exercise, intense emotion (fright, anger or pain) or by a loud noise.

\section{Table 1. Characteristics of the common forms of LQTS}

\begin{tabular}{llll}
\hline & LQT1 & LQT2 & LQT3 \\
\hline Gene mutated & KCNQ1 & KCNH2 & SCN5A \\
Current affected & IKs & IKr & INa \\
Estimated prevalence (\%) & 42 & 45 & $8-10$ \\
Mean QTC & $490 \pm 43$ & $495 \pm 43$ & $510 \pm 48$ \\
\% of events occurring with exercise or emotional stress & 97 & 51 & 39 \\
Exercise-related trigger & +++ & + & - \\
Other triggers & Swimming & Loud noise & Sleep/rest \\
\% with events before age 10* & 40 & 16 & 2 \\
\% with events before age $40^{\circ}$ & 63 & 46 & 18 \\
Median age at 1st event & 9 & 12 & 16 \\
QT shortening with exercise & $<$ Normal & Normal & $>$ Normal \\
Efficacy of $\beta$-blockade to prevent events & +++ & ++ & $+(?)$ \\
Efficacy of mexiletine to shorten QT & - & + & +++ \\
\hline
\end{tabular}

Clinical data are based on 112 LQT1 subjects, 72 LQT2 subjects, and 62 LQT3 subjects in the international Long QT registry, as reported by Zareba et al [6].. ${ }^{*} P<0.05$ among genotypes; $\| P<0.05$ male versus female. Adapted from Wilde AAM et al [7].

Already at young age individuals can exhibit syncope (fainting) or seizures due to cardiac arrhythmia, which is precipitated by an abnormal ventricular repolarization which is represented by the prolonged QTc time interval (Table 1). In 1979, the 
International Long QT Syndrome Registry had been initiated to investigate the epidemiological and genetic characteristics of the symptomatic probands with LQTS. From these data it has been estimated that $50 \%$ of the symptomatic probands of the LQT1 population had at least one episode of blacking out (fainting) by the age of 10. By the age of 40 the number of symptomatic patients who had experienced the first cardiac event had increased to almost $90 \%$. The majority of the individuals in the LQTS registry had one or more family members with a prolonged QT-interval [8-12].

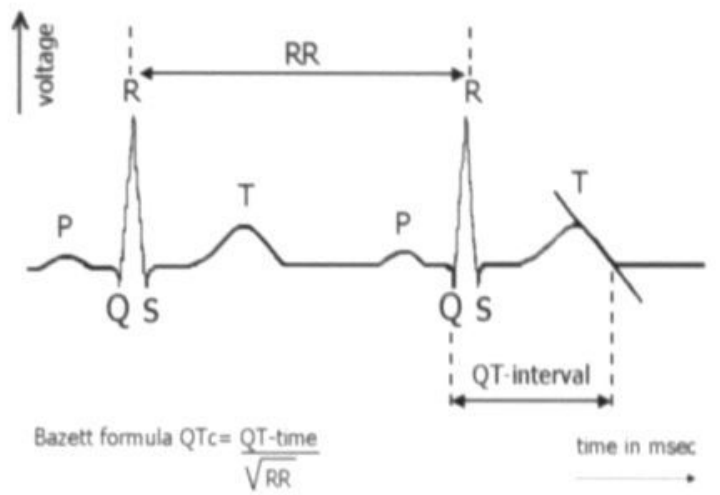

Figure 1. Schematic representation of the standard ECG. Symbol definitions: $P$ wave = depolarization of the atria; QRS complex = depolarization of the ventricles; $\mathrm{T}$-wave $=$ repolarization of the ventricles; $R R=$ rate rhythm; $Q T$ interval = time interval of the depolarization and the repolarization of the ventricular myocardium in milliseconds.

LQTS is characterized by a prolonged QT interval in lead II by standard 12 lead surface electrocardiogram ECG (Figure 1). The specific ECG pattern in LQTS is caused by abnormal lengthening of the repolarization phase of the ventricular myocardium which results in a prolongation of the QT interval. Index patients with a cardiac event are diagnosed at first on the basis of a prolonged QT interval (QTc) of \pm 440 milliseconds corrected for heart rate using the Bazett correction formula [13, 14]. However, recent studies of genotype-phenotype correlations indicated a value of \pm 460 milliseconds as more appropriate [8]. The value of the QT interval is also influenced by age and gender and QT interval duration in adult females is longer than in males [1517]. By introducing a set of diagnostic criteria for LQTS according to Schwartz, presented in Table 2, gender specific criteria were recommended to correct for the predominance of QTc prolongation in females [13]. The mechanism(s) behind this gender difference is still unclear but may be related to hormonal effects [16-19]. In LQTS patients a (sudden) change in heart rate, due to physical exercise or emotional stress may lead to malignant tachyarrhythmia or polymorphic ventricular arrhythmias 'torsade de pointes' meaning 'turning of the points' due to the alternating positive and negative major QRS complex named after a typically twisted French bread [20]. 


\section{Table 2. Criteria for diagnosis of LQTS syndrome}

\begin{tabular}{|c|c|}
\hline CHARACTERISTICS & POINTS \\
\hline \multicolumn{2}{|l|}{ Electrocardiographic findings ${ }^{\text {2) }}$} \\
\hline \multicolumn{2}{|l|}{ a. $\mathrm{QTc}^{21}$} \\
\hline$>480 \mathrm{msec}^{1,2)}$ & 3 \\
\hline $460-470 \mathrm{msec}^{1.21}$ & 2 \\
\hline $450 \mathrm{msec}$ (in males) ${ }^{1.2)}$ & 1 \\
\hline b. Torsade de pointes ${ }^{3)}$ & 2 \\
\hline c. T-wave alternans & 1 \\
\hline d. Notched T wave in the three leads & 1 \\
\hline e. Low heart rate for age ${ }^{4)}$ & 0.5 \\
\hline \multicolumn{2}{|l|}{ Clinical history } \\
\hline \multicolumn{2}{|l|}{ a. Syncope } \\
\hline With stress & 2 \\
\hline Without stress & 1 \\
\hline b. Congenital deafness & 0.5 \\
\hline \multicolumn{2}{|l|}{ Family history } \\
\hline a. Family members with LQTS & 1 \\
\hline b. Unexplained sudden death at age $<30 y$ among immediate & 0.5 \\
\hline
\end{tabular}

1. In the absence of medications or disorders known to affect these ECG features.

2. The QT value is corrected for heart rate by using the Bazett formula $Q T C=Q T / \sqrt{ } R R$, where RR indicates hart rate [14]

3. Mutually exclusive

4. Resting heart rate below the second percentile for age [26]

5. The same family cannot be counted in $a$ and $b$.

Adapted from Schwartz PJ et al [13]

In most cases the torsade de pointes is self terminating although, under certain circumstances, this arrhythmia may deteriorate in live threatening ventricular fibrillation and sudden cardiac death (SCD) caused by circulatory arrest [21-24]. This phenomenon classifies the LQTS as a malignant life threatening cardiac disorder. Therefore, abnormal ECG findings, a positive family history of unexplained syncope or sudden death of a young family member are very suspect for LQTS. A set of selection criteria, as proposed by Schwartz et al [13], is used to diagnose LQTS (Table 2). By allocating numeric points to the clinical features the possibility of LQT may be divided into low probability (score < 1 point), intermediate probability (score 2-3 points) or high probability (score > 4 points). In 1999 these criteria were modified by Priori et al [25]. They concluded that in some families, LQTS may appear with very low penetrance of $25 \%$, which has important clinical implications. The asymptomatic family members are considered to be normal but in fact, are silent gene carriers and are at risk of 
developing TdP if exposed to either drugs that block potassium channels. They are also unexpectedly at risk of generating affected offspring. Therefore it was no longer possible to exclude carrier-ship of LQTS in family members of affected patients on purely clinical grounds and molecular diagnosis should be performed to include or exclude individuals at risk [25]. Specialized laboratories nowadays offer molecular diagnostic tests to confirm the clinical diagnosis, and to genotype individuals at risk for carrier-ship (see also Chapter 4 of this thesis).

\section{2-2 The ventricular action potential}

The ventricular cardiac action potential is a reflection of subtle interactions of various cardiac ion channel proteins. In this section, only the channels that are involved in LQTS will be discussed. Cardiac ion channel proteins are located within the cellular membrane, creating a barrier between the intracellular and the extra-cellular compartment of the representation time and voltage dependant openings and closings [27].

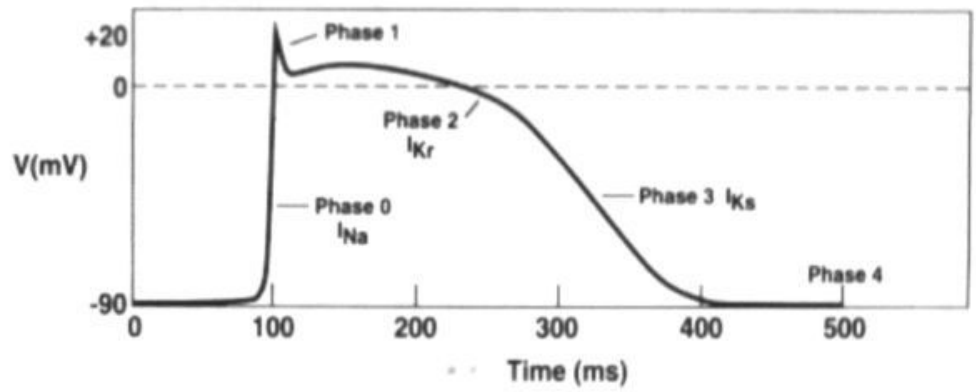

Figure 2. Overview of the ventricular action potential duration. Involvement of ion channels in cardiac action potential (phase 0-4). See text for further details. Modified from Towbin JA et al [28].

In a schematic overview (Figure 2), the four main phases of the ventricular action potential cell are indicated. By precise orchestrating, a number of voltage-gated ion channels selectively passes ions across the cell membrane. At rest, the cardiac cells have a negatively charged membrane potential with a Nernst potential equation of $-85 \mathrm{mV}$. The electric signal, is initiated by pacemaker cells, starting within the sinoatrial node (SA node) and is transmitted throughout the atria, atrioventricular node (AV node), the His-Purkinje system and the ventricles. In the initial phase of the action potential duration (phase 0 ), the voltage-gated sodium ( $\mathrm{Na}^{+}$) channels are rapidly activated and the cell membrane depolarizes. By briefly opening the ion channel, sodium ions are allowed to pass through the ion selective pores into the cell. During the inward sodium current $\left(I_{N a}\right)$, the membrane potential becomes less negatively charged and the sodium ion channels are closed by voltage dependent fast 
inactivation [29]. Early repolarization is initiated, immediately after inactivation of the sodium channels by the potassium transient outward current $\left(I_{\text {xto }}\right)$ in phase 1 , followed by a characteristic plateau phase. During this phase, the action potential is maintained by various small in- and outward currents such as calcium currents, ion exchangers and other voltage-gated ion channels. During the early plateau phase 2, the action potential is maintained by distinct calcium currents followed by the repolarization of the cell membrane in the late phase 2 and early phase 3 . The repolarization process begins when net outward current exceeds inward current. This phase is controlled by opening, inactivating and closing of three important delayed rectifying potassium channel currents $\left(I_{k}\right)$. Two potassium currents have been associated with LQTS, the rapidly activating delayed rectifier current $\left(I_{K_{k}}\right)$ and the slowly activating delayed rectifier current $\left(I_{\mathrm{K}_{\mathrm{s}}}\right)$. Finally, the membrane potential is brought back to the resting potential (phase 4). One should note that if the sodium channels are open, the potassium channels are closed.

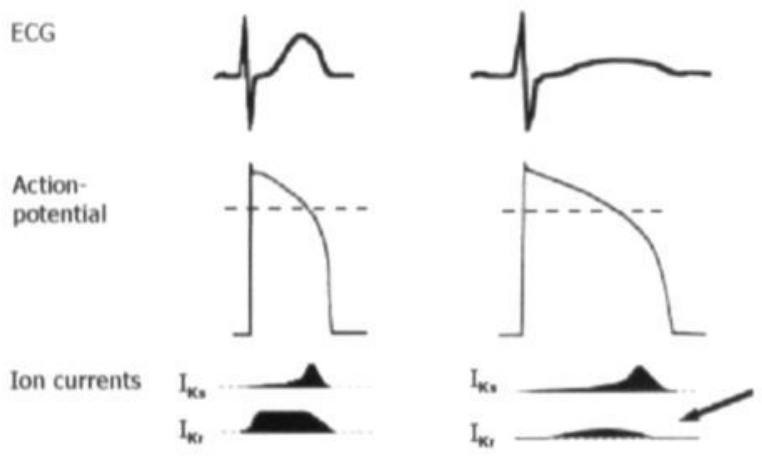

Figure 3. Schematic representation of action potential duration (APD) of two inward rectifying potassium ion channel currents $I_{\mathrm{k} s}$ and $\mathrm{I}_{\mathrm{k}, \mathrm{r}}$. At the left side the normal situation is represented, the right side represents the prolonged APD situation in LQTS. Note that the amplitude of the current $\mathrm{I}_{\mathrm{ks}}$ is delayed while the current $\mathrm{I}_{\mathrm{kr}}$ is decreased [30].

Mutations in genes, encoding these voltage gated ion channels, may lead to lower current amplitudes or influence the kinetics of these channels and cause improper gating behavior or altered openings or closings. As a result of this gating defect the membrane potential may be disturbed and the repolarization process can be delayed (Figure 3). The increase in action potential duration is reflected by a prolonged QT interval on the surface ECG. The delayed repolarization process predisposes individuals with LQTS to develop early after depolarizations (EAD) and promote reentrant excitation which is a common trigger for cardiac arrhythmias [31]. 


\section{2-3 Genetics of Long QT syndrome}

Congenital long QT syndrome (LQTS) is estimated to occur in 1 of 10.000-15.000 live births in the Caucasian population and is inherited as an autosomal dominant trait in the Romano Ward syndrome (RWS) or as a recessive trait in Jervell and Lange-Nielsen syndrome (JLNS) [32]. The JLNS is, in addition to a prolonged QT interval, associated with bilateral sensorineural hearing loss and the International Registry for LQTS has reported that congenital deafness is present in approximately $7 \%$ of the LQTS patients [12]. At present seven loci and genes (Table 3) including KCNQ1, KCNH2, SCN5A, KCNE1 and KCNE2 have been identified in LQTS [33-38]. The genetic defect on locus LQT4 finally has been identified as the AnkB gene which encodes an ankyrin-B isoform, a member of a family of versatile membrane adapters $[39,40]$.

Table 3. Chromosomal loci of LQTS, the corresponding genes, proteins and currents

\begin{tabular}{lcccc}
\hline Locus & Chromosome & Gene & Current & MIM $^{*}$ \\
\hline LQT1 & $11 p 15.5$ & KCNQ1 & $I_{\text {ss }}$ subunit & 192500 \\
LQT2 & $7 q 35-36$ & KCNH2 & $I_{\text {ks }}$ subunit & 152427 \\
LQT3 & $3 p 21-23$ & SCN5A & $I_{\text {Na }}$ subunit & 603830 \\
LQT4 & $4 q 25-27$ & AnkB & - & 600919 \\
LQT5 & $21 q 22.1-22.2$ & KCNE1 & beta-subunit & 176261 \\
LQT6 & $21 q 21.1-22.2$ & KCNE2 & beta-subunit & 603796 \\
LQT7 & $17 q 23-24$ & KCNJ2 & $I_{\text {K1 }}$ subunit & 170390 \\
& & & & \\
JLNS1 & $11 p 15.5$ & KCNQ1 & $I_{k s}$ subunit & 220400 \\
JLNS2 & $21 q 22.1-22.2$ & KCNE1 & beta-subunit & - \\
\hline
\end{tabular}

-MIM: Mendelian Inheritance in Man (http:www.ncbi.nlm.nih.gov/omim)

Recently, the KCNJ2 gene was added to the list as LQT7. Mutations in this gene are related to Andersen syndrome (AS) which is, besides a prolonged QT interval in a significant number of cases, associated with periodic paralysis, polymorphic ventricular tachcardia and dysmorphic features [41-43]. The two genes, KCNQ1 and KCNE1 have been identified to be involved in both JLNS (JLNS1-2) and RWS [44-46]. In a mouse model it has been demonstrated that both genes are abundantly expressed in cardiac tissue and in the stria vascularis of the cochlea $[47,48]$. At present, it is thought that mutations in the potassium channels impair the production of endolymph (impaired $\mathrm{K}+$ homeostasis) in the stria vascularis. The lack of endolymph supply accounts for deafness in JLNS patients [47]. In LQTS the majority of the mutations have been identified in two genes, KCNQ1 and KCNH2. The results of the genotyping effort in a group of Dutch LQTS families are in line with the results of an international large cohort reported by Splawski et al [38]. The KCNQ1 gene (LQT1) accounts for approximately $42-45 \%$ of the LQTS families, while the KCNH2 gene (LQT2) 
accounts for $40-45 \%$ and the SCN5A gene (LQT3) for $8-10 \%$ of the reported cases [7, 38, 49]. Mutations in the two regulatory potassium $\alpha$-subunits MinK (LQT5; KCNE1) and MiRP1 (LQT6; KCNE2) represent a very low percentage (2\%-3\%) of remainder LQTS families [38]. Besides the most frequently observed "loss-of-function" missense mutations, nonsense mutations, insertions and deletions have been reported as well $[38,50,51]$. Recently, in the KCNQ1 gene, also a "gain-of-function" mutation has been reported in a family with atrial fibrillation [52]. A list of the mutations ordered according to the nature of DNA substitution is presented in Table 4. Several investigators have also reported 'de novo' mutations in the KCNQ1 and KCNH2 genes. In this study we were able to identify 5 families with a 'de novo' mutation in one of the potassium channels. This was confirmed by haplotyping and mutation detection analysis (Chapter 3, this thesis).

Table 4. Overview of the mutations identified in LQTS genes

\begin{tabular}{llccccccc}
\hline Locus & Gene & Missense & Nonsense & Insertion & Deletion & Splicing & Total & $\%$ \\
\hline LQT1 & KCNQ1 & 72 & 3 & 3 & 13 & 7 & 98 & $37 \%$ \\
LQT2 & KCNH2 & 77 & 7 & 11 & 15 & 3 & 113 & $43 \%$ \\
LQT3 & SCN5A & 25 & - & 1 & 3 & - & 29 & $11 \%$ \\
LQT4 & ANK2 & 1 & - & - & - & - & & \\
LQT5 & KCNE1 & 14 & - & 1 & 2 & - & 17 & $6 \%$ \\
LQT6 & KCNE2 & 5 & - & - & - & - & 5 & $2 \%$ \\
LQT7 & KCNJ2 & 10 & - & - & 2 & - & 7 & \\
& Total & 203 & 10 & 16 & 35 & 10 & 262 & \\
\hline
\end{tabular}

The mutations were derived from the LQT database www.http://pc4.fsm.it:81/cardmoc

\section{2-4 Cardiac ion channels involved in LQTS}

In this section only the cardiac ion channel known to be related to the LQTS will be presented. These ion channels are expressed by genes encoding the pore forming $\alpha$ subunits and function-modifying accessory $\beta$-subunits [31].

\section{The cardiac potassium channels (LQT1 and LQT2)}

The molecular architecture and the pore forming structure of cardiac voltage-gated $\mathrm{K}^{+}$ channels is formed by tetramerization of four individual $\alpha$-subunits [53]. Each $\alpha$ subunit consists of six trans-membrane spanning regions (S1-S6). A putative voltage sensor is found in the S4 segment (Figure 4) while the pore forming loop is between the S5 and S6 segments [27, 54]. One of the cardiac potassium channel proteins is encoded by the KCNQ1 gene (LQT1) which is the $\alpha$-subunit component of the slowly 
activating delayed rectifier current $\left(I_{K_{3}}\right)$. The $\alpha$-subunit component of the rapidly activating delayed rectifier current ( $\left.I_{\mathrm{K}_{1}}\right)$ is encoded by the $\mathrm{KCNH} 2$ gene (LQT2) [34]. The KCNQ1 (KVLQT1) gene expresses alternatively spliced variants, the main isoform 1 and isoform 2. The $\mathbf{N}$-terminal splice variant (isoform 2) is expressed in the heart and is highest in the midmyocardium [55]. However, if expressed alone, no current is generated by isoform 2, but coexpression of both isoforms results in a dominant negative suppression of the $\mathrm{I}_{\mathrm{ks}}$ current generated by KCNQ1. In KCNH2 (HERG), two $\mathrm{N}$ terminal splice variants (HERG-A, HERG-B) and one C-terminal splice variant (HERGuso) have been identified. The HERG-A isoform is not cardiac specific and is also expressed in the brain while the HERG-B isoform is cardiac specific. HERG- $B$ is, despite a high RNA

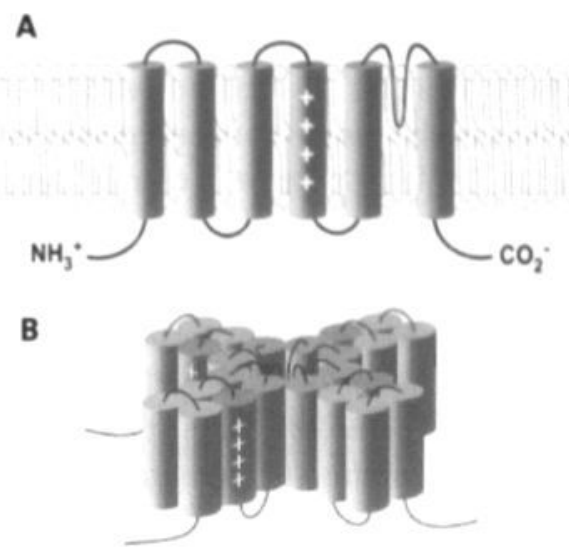

Figure 4. Structure of a voltage gated potassium channel. (Kv) $\alpha$ subunits are integral membrane proteins with six transmembrane domains (S1-S6), intracellular $\mathrm{N}$ - and C-termini and a the voltage sensor indicated by a positively charged $\mathrm{S} 4$ region (4A). Kv-potassium ion channels are constructed by assembly of four $\alpha$-subunits (4B). Adapted from Pond AL et al [54].

level in the heart, only in low amounts present as a protein. In heterologous expression the HERG-B isoform displays deactivation kinetics that resembles the $I_{k,}$ current [ 56 , 57]. The C-terminal variant HERGuso is present at $\approx 2$-fold higher levels in the human heart than the HERG-A isoform and does not itself generate $I_{k,}$ current [58]. However, it has a dominant negative effect on $I_{k r}$ when coexpressed in Ltk cells as it modifies the $\mathrm{I}_{\mathrm{k},}$ current by decreasing its amplitude, accelerating its activation and shifts the voltage dependent activation. Up to now it is still unknown whether the functional potassium ion channel $\mathrm{KCNH} 2$ is composed of alternatively spliced gene products (isoforms) or consists of homotetrameric $\alpha$-subunits. 


\section{Auxiliary subunits (LQT5 and LQT6)}

Voltage gated ion channels often include one or more ancillary proteins called auxiliary subunits or $\beta$-subunits that play a modulatory, structural, or stabilizing role [59]. A family of $\mathrm{K}^{+}$channel regulatory subunits are encoded by KCNE genes [60]. Two genes, KCNE1 and KCNE2, encoding the minimal potassium ion channel or minK (KCNE1) and the minK-related peptide 1 or MiRP1 (KCNE2), have been associated with LQT5 and LQT6 respectively $[36,37]$. Both proteins consist of a single transmembrane spanning region. The native currents $I_{\mathrm{ks}}$ and $\mathrm{I}_{\mathrm{k} r}$ are generated by co-expression of the KCNQ1 and $\mathrm{KCNH} 2$ protein with their corresponding auxiliary $\beta$-subunit, encoded by KCNE1 (LQT5) and KCNE2 (LQT6) which shows the heterogeneous composition of the functional ion channel $[37,61,62]$. To investigate the underlying mechanism for action potential prolongation and LQTS in KCNE2 associated mutations, it has been demonstrated that the kinetic changes, associated with coexpression of KCNE2 to $\mathrm{KCNH} 2$, have little effect whereas changes in channel conduction have large effects on action potential repolarization The large change in current density makes the affected patients susceptible to arrhythmias [63].

\section{The cardiac sodium channel (LQT3)}

The cardiac voltage-gated $\mathrm{Na}^{\prime}$ ion channel is encoded by the SCN5A gene and is highly expressed in human myocardium. The protein consists of four internally homologous domains (D1-DIV), each of which contains six membrane-spanning segments (S1-S6), similar to the structure of the potassium channel alpha-subunits. Segment S4 functions as the voltage sensor, important for voltage dependent activation (Figure 5). The four domains of the channel fold around a central ion-conducting pore, which is lined by the S5-S6 linker (referred to as the P-segment or P-loop) from each domain [28]. In addition to LQTS, mutations in the SCN5A gene have been associated with the Brugada syndrome (BS) which also may present as a familial form of cardiac electric instability and which is correlated with a high mortality rate [64]. The BS is characterized by unique ECG features of ST-segment elevations in leads V1 and V3 and is associated with or without right bundle branch block (RBBB) and ventricular fibrillation [65]. The distinct clinical presentation of LQT3 patients and BS patients was explained by expressing mutant sodium channels in a heterologous expression system. Mutations involved in BS resulted in decreased $\mathrm{Na}^{*}$ channel function by either decreased expression levels or various functional defects in activation and fast deactivation which promote reduced $\mathrm{Na}^{*}$ current density (loss-of-function) $[28,66]$. In Europe the incidence of SCN5A mutations in BS has been reported to be $15 \%$ in single cases which indicates genetic heterogeneity [67]. 
Since then, mutations in the SCN5A gene have been associated with idiopathic ventricle fibrillation (IVF) as well as in Lenegre Lev disease, a progressive form of cardiac conduction disease (PCCD) and with sudden infant death syndrome (SIDS) [68-71].

Outside

Voltage gated $\mathrm{Na}^{*}$ channel

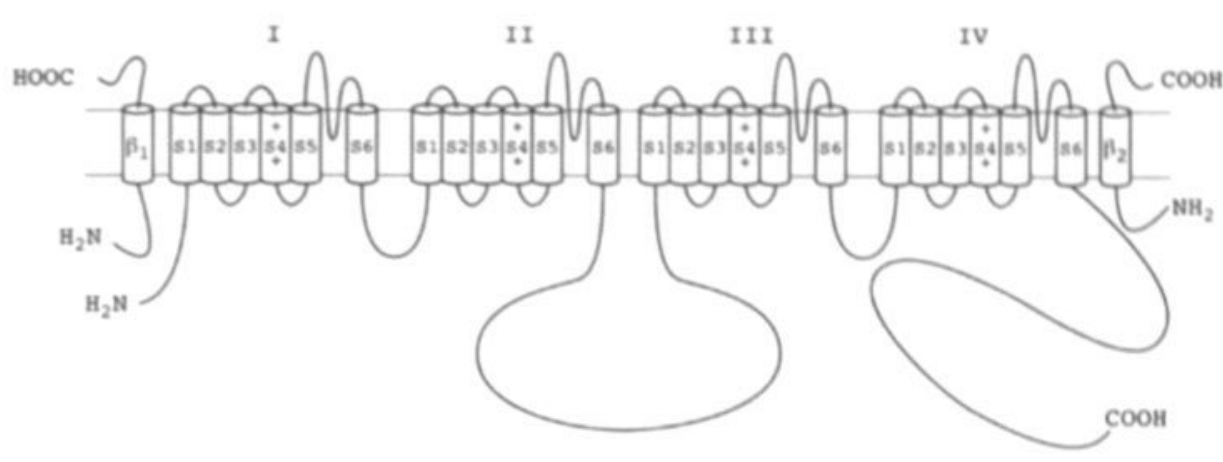

Figure 5. Structure of a voltage gated (Kv) $\alpha$-subunit sodium channel. The $\alpha$-subunit of the SCNSA gene consists of four homologous domains D1-DIV. Each domain consists of six transmembrane segments (S1-S6) and a pore forming region. The voltage sensor is indicated by a positively charged S4 region. On the outer left and right side two single transmembrane spanning auxiliary subunits are represented as well. The $\mathrm{N}$ - and C-terminal ends of the protein are located in the cytoplasm. Adapted from Felix R et al [72].

\section{2-5 Mutations in ion channel genes are causative for cardiac events in LQTS}

The dominant negative effect of mutated ion channel proteins has been demonstrated by measuring the current in Xenopus laevis oocytes or mammalian cells by heterologeous expression of mutated and wild type alleles [73, 74]. These functional tests demonstrated that mutations identified in the SCN5A gene (phase 1) caused delayed inactivation (improper, late closing), and a persistent opening of the channel which increases the time of repolarization (prolongation of the QT interval) hence explaining the long QT syndrome phenotype LQT3. In contrary mutations identified in the rapid- and slow activating rectifying potassium ion channels demonstrated premature inactivation (closing) which caused delayed repolarization and prolonged action potential duration explaining the long QT phenotypes involved in LQT1 and LQT2. According to these observations two mechanism have been proposed. The mechanism 'loss or gain of function' has been proposed to indicate the dominant effect of missense mutations in most cases. A second mechanism is haploinsufficiency and has been suggested in case of trafficking defects of the misfolded protein, or severely disrupted subunits unable to associate with normal subunits. These mutations will lead to a reduced number of functional ion channels. In either case, the 
currents are expected to be reduced by 50\% (haploinsufficiency) or more (dominant negative effect) [27].

In mutated potassium ion channels, the loss of function may result in reduced gating properties by modification of the ion channel kinetics due to incorporation of a mutated $\alpha$ - or $\beta$-subunit $[27,75]$. As potassium channels are assembled into tetramers, mutated proteins may be incorporated by chance. If the mutant freely and at random associates with wild type subunits into a tetramer and if the mutant is completely dominant, the current would be reduced to $1 / 16$ (fraction of wild type $=0.5$; tetramer $=4$; the contribution is $0.5^{4}=1 / 16$ ) and finally result in an overall reduced $\mathrm{K}^{+}$current (loss of function) indicating that the defective protein is capable of blocking the entire current by interaction with the wild type protein $[50,76]$. Reduced $\mathrm{K}^{+}$currents prolong action potential duration, a phenomenon which has been observed in individuals with a KCNQ1 (LQT1) or a KCNH2 (LQT2) mutation. An identical mechanism has been proposed in SCN5A mutations which resulted in a sustained opening (gain of function) of the $\mathrm{Na}^{\prime}$ ion channel in case of LQT3 mutations. The protein defect will be present in at least $50 \%$ of the expressed sodium ion channels.

Insufficient or loss of functional ion channels (haploinsufficiency) may be the result of inefficient co-assembly of subunits (i.e. potassium channels) or trafficking deficiency from the endoplasmic reticulum to the plasma membrane as a result of (posttranslational) modification or misfolding of the ion channel protein. In KCNQ1 and also in $\mathrm{KCNH} 2$ C-terminal mutations (missense, nonsense or frame shift inducing mutations) have been reported that caused a forme fruste of LQTS by misprocessing or trafficking defects due to post-translational processes [77-83].

In families with JLNS the disease is transmitted in an autosomal recessive pattern. Patients with JLNS have severe prolonged QTC values and cardiac events appears earlier in life than in RWS patients [47]. Up to now two loci for JLNS have been identified. Homozygous and compound heterozygous mutations in both the KCNQ1 gene and KCNE1 gene represent JLNS1 and JLNS2 respectively $[46,84,85]$. In JLNS homozygous mutations (the human knock-out) or compound heterozygous mutations lead to complete loss of the functional cardiac potassium current $I_{\mathrm{ks}}$ explaining the severe cardio-auditory syndrome $[45,46,86]$. Parents of these patients carry a single mutation in either the KCNQ1 or KCNE1 gene, which may lead to a mild cardiac phenotype without hearing loss. Heterozygotes of a specific KCNE1 mutation showed prolonged QTC values however, QTc prolongation was not always present in case of a KCNQ1 mutation and gene carriers were phenotypically normal $[45,85,86]$. 


\section{2-6 Gene specific triggers in LQTS}

By the initiation of the International LQTS Registry it has become possible to study retrospectively a large genotyped population expressing various clinical characteristics like the QTc-value, the trigger of the events, the frequency of the events and the age of onset of symptoms. In the LQTS registry about $1 / 3$ of the individuals had recurrent syncope, 1/3 had problems during adolescence and 1/3 had no symptoms. Reports have indicated that these episodes of syncope and seizures are related to gene specific triggers [87, 88](Chapter 5 this thesis). Additional studies in a larger population indicated that the number of incidents was highest in LQT1 patients and lowest in LQT3 patients (LQT1 $>$ LQT2>LQT3). The majority of LQT1 patients experienced events during exercise and exercise related stress (in particular swimming or diving), LQT2 patients showed cardiac events after a loud noise (by arousal) or an emotional trigger, while LQT3 patients mainly presented cardiac events during sleep. According to Schwartz [8] the median age at onset for the first major cardiac event is before the age of 10 years in $50 \%$ of the LQT1 patients. In contrary, mostpart of the LQT2 and LQT3 patients were still asymptomatic at age 16. Although the events in the LQT3 patients were less frequent, the risk for sudden death was higher in LQT3 than LQT2 and LQT1 $[8,89,90]$. In addition to a gene-specific correlation, the clinical phenotype has also been correlated with the position of the genetic defect within the ion channel structure. Missense mutations in the C-terminal domain in the LQT1 locus have been associated with a forme fruste phenotype and low penetrance [25, 77]. In contrary, missense mutations which reside in the transmembrane spanning domains have been reported to be associated with a more severe clinical phenotype [91].

\section{2-7 Acquired long QT syndrome}

The acquired or drug induced form of LQTS (aLQTS) exhibits a similar form of ventricular arrhythmia or Torsade de Pointes, often occurring after administration of specific drugs. The potassium channel KCNH2 (HERG) which is responsible for the LQT2 subtype, is a medication (also cocaine and alcohol) sensitive ion channel, in particular for QT-prolonging medication like anti-arrhythmic and antidepressant drugs. In addition, the $I_{k r}$ current is sensitive to electrolyte imbalances such as low extra-cellular potassium level (hypokalemia), hypomagnesia and hypocalcemia, in particular in combination with medications mentioned above [92].

Another plausible explanation for the acquired form of LQT is the architecture of the ion selective pore domain and the amino acid composition of the S6-region [93]. However, despite extensive research only few mutations (Table 5) in ion channels have been reported in patients with drug-induced LQT (Paulussen ADC, thesis). Some mutations in $\mathrm{KCNH} 2$ have been correlated with hypokalemia-induced LQT syndrome and, under normal conditions, they present a mild clinical phenotype suggesting an aLQTS [99, 100]. One single amino acid polymorphism (Thr8Ala, freq.1.6\% in the 
general population) in the auxiliary $\alpha$-subunit KCNE2 (LQT5) has been associated with antibiotic-induced cardiac arrhythmia [98]. The genetic predisposition for aLQTS may not only depend on ion channel dysfunction but may also derive from genetic variations in drug metabolizing enzymes [101, 102]. Finally, sinus bradycardia, left ventricular cardiomyopathy and female sex predispose individuals to the acquired form of LQT [24, 30]. The female predisposition for aLQTS is probably correlated with the longer QT intervals among females as the acquired LQT syndrome occurs more often in this group $[18,103,104]$. A list of QT-interval prolonging drugs is available at www.qtdrugs.org.

Table 5. DNA variants in drug-induced long QT

\begin{tabular}{|c|c|c|c|c|}
\hline Channel & Variant & Drug & Usage & Reference \\
\hline$K C N Q 1 / I_{\mathrm{ks}}$ & $\mathrm{R} 583 \mathrm{C}$ & Dofetilide & Anti-arrhythmic & Yang et al [94] \\
\hline $\mathrm{KCNQ} 1 / \mathrm{I}_{\mathrm{Ks}}$ & Y315C & Cisapride & $\begin{array}{l}\text { Cholinergic } \\
\text { antagonist }\end{array}$ & Napolitano et al [95] \\
\hline $\mathrm{KCNH} 2 / \mathrm{I}_{\mathrm{Kr}}$ & R328C & $\begin{array}{l}\text { Meta-iodobenzyl- } \\
\text { guanidine, a } \\
\text { norepinephrine and } \\
\text { guanethidine analogue }\end{array}$ & $\begin{array}{l}\text { Vasconstrictor, } \\
\text { Inotrope }\end{array}$ & Chevalier et al [96] \\
\hline $\mathrm{KCNH} 2 / I_{K r}$ & R784W & Amiodarone & Anti-arrhythmic & Yang et al [94] \\
\hline SCN5A/I & G615E & Quinidine & Anti-arrhythmic & Yang et al [94] \\
\hline SCN5A/I & L618F & Quinidine & Anti-arrhythmic & Yang et al [94] \\
\hline SCN5A/I & F1250L & Sotalol & Anti-arrhythmic & Yang et al [94] \\
\hline SCN5A/I & L1825P & Cisapride & Prokinetic & Makita et al [97] \\
\hline MiRP1 & Q9E & Chlarithromycine & Antibiotic & Abbott et al [37] \\
\hline MiRP1 & $\mathrm{A} 116 \mathrm{~V}$ & Quinidine & Anti-arrhythmic & Sesti et al [98] \\
\hline MiRP1 & T8A & Sulfametoxazole & Antibiotic & Sesti et al [98] \\
\hline MiRP1 & M54T & Procainamide & Anti-arrhythmic & Sesti et al [98] \\
\hline MiRP1 & $157 \mathrm{~T}$ & Oxatomide & Antihistamine & Sesti et al [98] \\
\hline
\end{tabular}

These drugs have been reported to provoke ventricular tachycardia in the presence of a specific mutation in one of the LQTS genes

\section{2-8 Gene-based medical therapy in LQTS patients}

Syncope and sudden death in the congenital as well as in the acquired form of Long QT syndrome, is caused by specific arrhythmia known as polymorphous ventricular tachycardia, or Torsade de Pointes. The goal of the medical treatment is, to protect these individuals against this dangerous arrhythmic event. Untreated symptomatic individuals have a 10 -year mortality of $50 \%$ and a mortality rate from $1 \%$ to $2 \%$ per year $[24,105]$. In the past 10 years we have gained better insight in the pathogenetic en pathophysiologic aspects of the LQTS. Different genes are involved in the 
repolarization defect and treatment will thus depend on the type of the ion channel involved. Therefore identification of the genetic defect is essential. Currently, the standard therapeutic approach in LQTS is the initiation of $\beta$-blockers at the time of diagnosis. In LQT1 and LQT2 patients medical treatment mainly includes drug administration by using antiarrhythmics i.e. propranolol [106].

In case of a LQT3 mutation, patients may benefit from treatment with a sodium channel blocking agent (Class IB antiarrhythmics i.e. mexilitin). The group of LQT3 patients that suffer from severe sinus bradycardy, may benefit from pacemaker therapy or in combination with an implantable defibrillator [107]. In the group of LQT2 patients medical treatment was improved by a supplement treatment of exogenous potassium therapy [108]. The effect of beta-blocker therapy in the LQTS population has been reported in a retrospective study by Itoh et al [109]. In this study, physicians reported that patients who carry a mutation in the KCNQ1 gene responded better to beta-adrenergic blocking agents than those with a mutation in the $\mathrm{KCNH}_{2}$ gene. Besides a gene specific response to medical therapy a gender effect on betaadrenoceptor blockade treatment has been reported as well by Conrath et al. This study was performed in a Dutch group of genotyped patients having a mutation in either locus LQT1 or LQT2 [110]. The question has been raised whether presymptomatic carriers of a genetic defect should be treated by medication. Vincent et al recommended medical treatment of asymptomatic patients if they were under age 40 at the time of clinical diagnosis [111]. If therapy fails, a less frequent used therapy is left stellate ganglion block or ablation. This treatment was based on the Sympathetic Imbalance Theory [112]. Adrenergic stimulation increases the heart rate and by blocking the autonomic nervous system by left cardiac sympathectomy (left stellate ganglionectomy) this arrhythmogenic substrate may be circumvented [113]. Nowadays the application of an implantable defibrillator may be indicated if patients maintain symptoms despite medication [24].

The influence of pregnancy among patients with LQTS was investigated in a large study by Rashba et al. They showed that the postpartum interval ( \pm 40 weeks) was associated with a significant increase in risk for cardiac events and they proposed that during pregnancy and postpartum intervals the prophylactic treatment should be continued [114].

\section{References}

1. Romano C. Aritmie cardiache rare dell' eta pediatrica. II. Accessi sincopali per fibrillazione ventricolare parossistica. Clin Pediat. 1963:45:656-683.

2. Ward OC. A new familial cardiac syndrome in children. J Irish Med Assoc. 1964;54:103-106.

3. Jervell A, Lange-Nielsen F. Congenital deaf-mutism, functional heart disease with prolongation of the QT interval and sudden death. Am Heart J. 1957:54:59-68.

4. Meissner FL. Taubstummheit und taubstummheitsbildung. Leipzip/ Heidelberg: C.F. Winter'sche Verlagshandlung 1856. 
5. Herrlin KM, Moller T. A case of cardiac syncope. Acta Paediatrica 1953;42:467-75.

6. Zareba W, Moss AJ, Schwartz PJ, Vincent GM, Robinson JL, Priori SG, Benhorin J, Locati EH, Towbin JA, Keating MT, Lehmann MH, Hall WJ. Influence of genotype on the clinical course of the long-QT syndrome. International Long-QT Syndrome Registry Research Group. N Engl J Med. 1998;339:960-965.

7. Wilde AAM, Roden DM. Predicting the Long-QT Genotype From Clinical Data. From Sense to Science. Circulation. 2000;102:2796-2798.

8. Schwartz PJ, Priori SG, Spazzolini C, Moss AJ, Vincent M, Napolitano C, Denjoy, Guicheney P, Breithard G, Keating MT, Towbin JA, Beggs AH, Brink P, Wilde AAM, Toivonen L, Zareba W, Robinson JL, Timothy KW, Corfield V, Wattanasirichaigoon D, Corbett C, Haverkamp W, SchulzeBahr E, Lehmann MH. Schwartz K, Coumel P, Bloise R. Genotype-phenotype correlation in the long-QT syndrome: Gene-specific triggers for life-threatening arrhythmias. Circulation. 2001;103:89-95.

9. Schwartz PJ, Moss A. Prolonged Q-T interval: what does it mean? J Cardiovasc Med. 1982;7:1317-1330.

10. Schwartz PJ. The idiopathic long QT syndrome: the need for a prospective registry. Eur Heart J. 1983:4:529-531.

11. Moss AJ, Schwartz PJ, Crampton RS, Locati E, Carleen E. The long QT syndrome: a prospective international study. Circulation. 1985;71:17-21.

12. Moss AJ, Schwartz PJ, Crampton RS, Tzivoni D, Locati EH, MacCluer J, Hall WJ, Weitkamp L, Vincent GM, Garson A, et al. The long QT syndrome Prospective longitudinal study of 328 families. Circulation. 1991;84:1136-1144.

13. Schwartz PJ, Moss AJ, Vincent GM, Crampton RS. Diagnostic criteria for the long QT syndrome. An update. Circulation. 1993;88:782-784.

14. Bazett HC. An analysis of the time-relations of electrocardiograms. Heart. 1920;7:353-370.

15. Rautaharju PM, Zhou SH, Wong S, Calhoun HP, Berenson GS, Prineas R, Davignon A. Sex differences in the evolution of the electrocardiographic QT-interval with age. Can J Cardiol. 1992;8:690-695.

16. Lehmann MH, Timothy KW, Frankovich D, Fromm BS, Keating M, Locati EH, Taggart RT, Towbin JA, Moss AJ, Schwartz PJ, Vincent GM. Age-gender influence on the rate-corrected QT interval and the QT-heart rate relation in families with genotypically characterized long QT syndrome. J Am Coll Cardiol. 1997;29:93-99.

17. Locati EH, Zareba W, Moss AJ, Schwartz PJ, Vincent GM, Lehmann MH, Towbin JA, Priori SG, Napolitano C, Robinson J, Andrews M, Timothy K, Hall WJ. Age- and sex-related differences in clinical manifestations in patients with congenital long-QT syndrome. Circulation. 1998;97:2237-2244.

18. Wolbrette D, Patel H. Arrhythmias and women. Curr Opin Cardiol. 1999:14:36-43.

19. Wolbrette D, Naccarelli G, Curtis A, Lehmann M, Kadish A. Gender differences in arrhythmias. Clin Cardiol. 2002;25:49-56.

20. Dessertenne F. La Tachycardy ventriculaire a deux foyers opposes variables. Ventricular tachycardia with 2 variable opposing foci. Arch Mal Coeur Vaiss. 1966;59:263-272.

21. Roden DM, Lazzara R, Rosen M, Schwartz PJ, Towbin J, Vincent GM. Multiple mechanisms in the long-QT syndrome. Current knowledge, gaps, and future directions. The SADS Foundation Task Force on LQTS. Circulation. 1996:8:1996-2012.

22. Lazarra R. Twisting of the points. J Am Coll C ard. 1997;29:843-845.

23. el-Sherif N, Turitto G. The long QT syndrome and torsade de pointes. Pacing Clin Electrophysiol. 1999;22:91-110.

24. Khan IA. Clinical and therapeutic aspects of congenital and acquired long QT syndrome. Am J Med. 2002;112:58-66.

25. Priori SG, Napolitano C, Schwartz PJ. Low penetrance in the long-QT syndrome: clinical impact. Circulation. 1999:99:529-533. 
26. Davignon A, Rautaharju B, Boiselle E, Soumis F, Megelas M, Choquette A. Normal ECG standards for infants and children. Pediatr Cardiol. 1980;1:123-130.

27. Snyders DJ. Structure and function of cardiac potassium channels. Cardiovasc Res. 1999:42:377-390.

28. Towbin JA, Vatta M. Molecular Biology and the Prolonged QT Syndromes. Am J Med. 2001;110:385-398.

29. Bezzina CR, Rook MB, Wilde AA. Cardiac sodium channel and inherited arrhythmia syndromes. Cardiovasc Res. 2001:49:257-271.

30. Wilde AA. Geneesmiddelen en het lange QT-interval. Gebu. 2002:36:27-32.

31. Roden DM, Balser JR, George Jr AL, Anderson ME. Cardiac Ion Channels. Annu Rev Physiol. 2002;64:431-475.

32. Ackerman M. The long QT syndrome: ion channel disease of the heart. Mayo Clin Proc. 1998;73: 250-269.

33. Wang Q, Curran ME, Splawski I, Burn TC, Millholland JM, VanRaay TJ, Shen J, Timothy KW, Vincent GM, de Jager T, Schwartz PJ, Towbin JA, Moss AJ, Atkinson DL, Landes GM, Connors TD, Keating MT. Positional cloning of a novel potassium channel gene: KVLQT1 mutations cause cardiac arrhythmias. Nature Genet. 1996;12:17-23.

34. Curran ME, Splawski I, Timothy KW, Vincent GM, Green ED, Keating MT. A molecular basis for cariac arrhythmia: HERG mutations cause long QT syndrome. Cell. 1995:80:795-803.

35. Wang Q, Shen J, Splawski I, Atkinson D, Li Zhizhong, Robinson JL, Moss AJ, Towbin JA, Keating MT. SCNSA mutations associated with an inherited cardiac arrhythmia, long QT syndrome. Cell. 1995;80:805-811.

36. Splawski I, Tristani-Firouzi M, Lehrmann MH, Sanguinetti M, Keating MT. Mutations in the hminK cause long QT syndrome and suppress Iks function. Nature Genetics. 1997:17:338-340.

37. Abbott GW, Sesti F, Splawski I, Buck ME, Lehmann MH, Timothy KW, Keating MT, Goldstein SA. MiRP1 forms IKr potassium channels with HERG and is associated with cardiac arrhythmia. Cell. 1999;97:175-187.

38. Splawski I, Shen J, Timothy KW, Lehmann MH, Priori S, Robinson JL, Moss AJ, Schwartz PJ, Towbin JA, Vincent GM, Keating MT. Spectrum of mutations in long-QT syndrome genes. KVLQT1, HERG, SCN5A, KCNE1, and KCNE2. Circulation. 2000;102:1178-1185.

39. Schott JJ, Charpentier F, Peltier S, Foley P, Druin E, Bouhour JB, Donneley P, Vergnaud G, Bachner L, Moisan JP, Le Marec H, Pascal O. Mapping of a gene for long QT syndrome to chromosome 4925 27. Am J Hum Genet. 1995;57:1114-1122.

40. Mohler PJ, Schott JJ, Gramolini AO, Dilly KW, Guatimosim S, DuBell WH, Song LS, Haurogne K, Kyndt F, Ali ME, Rogers TB, Lederer WJ, Escande D, Marec HL, Bennett V. Ankyrin-B mutation causes type 4 long-QT cardiac arrhythmia and sudden cardiac death. Nature. 2003:421:634-639.

41. Canun S, Perez N, Beirana LG. Andersen syndrome autosomal dominant in three generations. Am J Med Genet. 1999;85:147-156.

42. Plaster NM, Tawil R, Tristani-Firouzi M, Canun S, Bendahhou S, Tsunoda A, Donaldson MR, lannaccone ST, Brunt E, Barohn R, Clark J, Deymeer F, George AL Jr, Fish FA, Hahn A, Nitu A, Ozdemir C, Serdaroglu P, Subramony SH, Wolfe G, Fu YH, Ptacek U. Mutations in Kir2.1 cause the developmental and episodic electrical phenotypes of Andersen's syndrome. Cell. 2001;105:511-519.

43. Tristani-firouzi M, Jensen JL, Donaldson MR, Sansone V, Meola G, Hahn A, Bendahhou S, Kwiecinski H, Fidzianska A, Plaster N, Fu YH, Ptacek U, Tawil R. Functional and clinical characterization of KCNJ2 mutations associated with LQT7 (Andersen syndrome). I Clin Invest. 2002;110:381-388.

44. Schulze-Bahr E, Haverkamp W, Wedekind H, Rubie C, Hördt M, Borggreve M, Assmann G, Breithardt G, Funke $\mathrm{H}$. Autosomal recessive long-QT syndrome (Jervell Lange-Nielsen syndrome) is genetically heterogeneous. Hum Genet. 1997;100:573-576. 
45. Tyson J, Tranebjærg L, Bellman S, Wren C, Taylor J, Bathen J, Aslaksen B, Sørland SJ, Lund O, Malcolm S, Pembrey M, Bhattacharya S, Bitner-Glindzicz M. IsK and KvLQT1: mutation in either of the two subunits of the slow component of the delayed rectifier potassium channel can cause Jervell and Lange-Nielsen syndrome. Hum Mol Genet. 1997;12:2179-2185.

46. Schulze-Bahr E, Wang Q Wedekind H, Haverkamp W, Chen Q Sun Y. KCNE1 mutations cause Jervell and Lange-Nielsen Syndrome. Nat Genet. 1997;17:267-268.

47. Neyroud N, Tesson F, Denjoy I, Leibovici M, Donger C, Barhanin J, Fauré S, Gary F, Coumel P, Petit C, Schwartz K, Guicheney P. A novel mutation in the potassium channel gene KVLQT1 causes Jervell Lange-Nielsen cardioauditory syndrome. Nat Genet. 1997;15:186-189.

48. Nicolas M, Dememes D, Martin A, Kupershmidt S, Barhanin J. KCNQ1/KCNE1 potassium channels in mammalian vestibular dark cells. Hearing Research. 2001;153:132-145.

49. Jongbloed RJ, Wilde AA, Geelen JL, Doevendans P, Schaap C, Van Langen I, van Tintelen JP, Cobben JM, Beaufort-Krol GC, Geraedts JP, Smeets HJ. Novel KCNQ1 and HERG missense mutations in Dutch long-QT families. Hum Mut. 1999:13:301-310.

50. Geelen JL, Doevendans PA, Jongbloed RJ, Wellens HJ, Geraedts JP. Molecular genetics of inherited long QT syndromes. Eur Heart J. 1998;10:1427-33.

51. Wehrens $X \mathrm{H}$, Doevendans PA, Wellens HJ, Vos $\mathrm{M}$. Novel insights in the congenial long QT-3 syndrome. Ann Int Med. 2002;137:981-992.

52. Chen YH, Xu SJ, Bendahhou S, Wang XL, Wang Y, Xu WY, Jin HW, Sun H, Su XY, Zhuang QN, Yang YQ Li YB, Liu Y, Xu HJ, Li XF, Ma N, Mou CP, Chen Z, Barhanin J, Huang W. KCNQ1 gain-of-function mutation in familial atrial fibrillation. Science. 2003;299:251-254.

53. Mac Kinnon R. Determination of the subunit stochiometry of a voltage-activated potassium channel. Nature. 1991;350:232-235.

54. Pond AL, Nerbonne JM. ERG Proteins and Functional Cardiac IKr Channels in Rat, Mouse, and Human Heart. Trends in Cardiovasc Med. 2000;11:286-294.

55. Pereon Y, Demolombe S, Baro I, Drouin E, Charpentier F, Escande D. Differential expression of KvLQT1 isoforms across the human ventricular wall. Am J Physiol Heart Circ Physiol. 2000;278:H1908-1915.

56. London B, Trudeau MC, Newton KP, Beyer AK, Copeland NG, Gilbert DJ, Jenkins NA, Satler CA, Robertson GA. Two isoforms of the mouse ether-a-go-go-related gene coassemble to form channels with properties similar to the rapidly activating component of the cardiac delayed rectifier K+ current. Circ Res. 1997;81:870-878.

57. Lees-Miller JP, Kondo C, Wang L, Duff HJ. Electrophysiological characterization of an alternatively processed ERG K+ channel in mouse and human hearts. Circ Res. 1997;81:719-726.

58. Kupershmidt S, Snyders DJ, Raes A, Roden DM. A K+ channel splice variant common in human heart lacks a C-terminal domain required for expression of rapidly activating delayed rectifier current. J Biol Chem. 1998;273:27231-27235.

59. Catterall WA. Structure and function of voltage-gated ion channels. Annu Rev Biochem. 1995:64:493-531.

60. Sanguinetti MC. Maximal function of minimal K+ channel subunits. Trends Pharmacol Sci. 2000;21:199-201.

61. Barhanin J, Lesage F, Guillemare E, Fink M, Lazdunski M, Romey G. K(V)LQT1 and IsK (minK) proteins associate to form the I(Ks) cardiac potassium current. Nature. 1996;384:78-80.

62. Sanguinetti $M$, Curran $M$, Spector P, Keating $M$. Spectrum of HERG $K+$--channel dysfunction in an inherited cardiac arrhythmia. Proc Natl Acad Sci. 1996;93:2208-2212.

63. Mazhari R, Greenstein JL, Winslow RL, Marban E, Nuss HB. Molecular interactions between two long-QT syndrome gene products, HERG and KCNE2, rationalized by in vitro and in silico analysis. Circ Res. 2001;89:33-38. 
64. Brugada J, Brugada R, Brugada P. Right bundle-branch block and ST-segment elevation in leads VI through V3. A marker for sudden death in patients without demonstrable structural heart disease. Circulation. 1998:97:457-460.

65. Brugada P, Brugada J. Right bundle branch block, persistent ST segment elevation and sudden cardiac death: a distinct clinical and electrocardiographic syndrome. A multicenter report. I Am Coll Cardiol. 1992;20:1391-1391.

66. Chen Q, Kirsch GE, Zhang D, Brugada R, Brugada J, Brugada P, Potenza D, Moya A, Borggrefe M, Breithardt G, Ortiz-Lopez R, Wang Z, Antzelevitch C, O'Brien RE, Schulze-Bahr E, Keating MT, Towbin JA, Wang $Q$. Genetic basis and molecular mechanism for idiopathic ventricular fibrillation. Nature. 1998;392:293-296.

67. Priori SC. Clinical and genetic heterogeneity of right bundle branch block and ST-segment elevation syndrome: A prospective evaluation of 52 families. Circulation. 2000;102:2509-2015.

68. Brugada P, Brugada R, Brugada J. The brugada syndrome. Curr Cardiol Rep. 2000;2:507-514.

69. Schott JJ, Alshinawi C, Kyndt F, Probst V, Hoorntje TM, Hulsbeek M, Wilde AA, Escande D, Mannens MM, Le Marec H. Cardiac conduction defects associate with mutations in SCN5A. Nat Genet. 1999;23:20-21.

70. Tan HL, Bink-Boelens MTE, Bezzina CR, Viswanathan PC, Beaufort-Krol GCM, van Tintelen PJ, van den Berg MP, Wiide AAM, Balser JR. A sodium-channel mutation causes isolated cardiac conduction disease. Nature. 2001;409:1043-1047.

71. Ackerman MJ, Siu BL, Sturner WQ, Tester DJ, Valdivia CR, Makielski JC, Towbin JA. Postmortem molecular analysis of SCNSA defects in sudden infant death syndrome. JAMA. 2001;286:2264-2269.

72. Felix R. Channelopathies: ion channel defects linked to heritable clinical disorders. I Med Genet. 2000;37:729-740.

73. Wollnik B, Schroeder BC, Kubisch C, Esperer HD, Wieacker P, Jentsch TJ. Pathophysiological mechanisms of dominant and recessive KVLQT1 K+ channel mutations found in inherited cardiac arrhythmias. Hum Mol Genet. 1997;6:1943-1949.

74. Vatta M, Li H, Towbin JA. Molecular biology of arrhythmic syndromes. Curr Opin Cardiol. 2000;15:12-22.

75. Keating MT, Sanguinetti MC. Pathophysiology of ion channel mutations. Curr Opin Genet. 1996;6:326-333.

76. Kagan A, Yu Z, Fishman GI, McDonald TV. The dominant negative LQT2 mutation A561V reduces wild-type HERG expression. J Biol Chem. 2000;275:11241-11248.

77. Donger C, Denjoy I, Berthet M, Neyroud N, Cruaud C, Bennaceur M, Chivoret G, Schwartz K, Coumel P, Guicheney P. KVLQT1 C-Terminal Missense Mutation Causes a Forme Fruste Long QTSyndrome. Circulation. 1997; 96:2778-2781.

78. Furutani M, Trudeau MC, Hagiwara N, Seki A, Gong Q, Zhou Z, Imamura S, Nagashima H, Kasanuki H, Takao A, Momma K, January CT, Robertson GA, Matsuoka R. Novel mechanism associated with an inherited cardiac arrhythmia: defective protein trafficking by the mutant HERG (G601S) potassium channel. Circulation. 1999;99:2290-2294.

79. Zhou Z, Gong Q January CT. Correction of defective protein trafficking of a mutant HERG potassium channel in human long QT syndrome. Pharmacological and temperature effects. J Biol Chem. 1999;274:31123-31126.

80. Ficker E, Thomas D, Viswanathan PC, Dennis AT, Priori SG, Napolitano C, Memmi M, Wible BA, Kaufman ES, lyengar S, Schwartz PJ, Rudy Y, Brown AM. Novel characteristics of a misprocessed mutant HERG channel linked to hereditary long QT syndrome. Am I Physiol Heart Circ Physiol. 2000;279:H1748-1756.

81. Ficker E, Dennis AT, Obejero-Paz CA, Castaldo P, Taglialatela M, Brown AM. Retention in the endoplasmic reticulum as a mechanism of dominant-negative current suppression in human long QT syndrome. J Mol Cell Cardiol. 2000;32:2327-2337. 
82. Paulussen A, Raes A, Matthijs G, Snyders DJ, Cohen N, Aerssens J. A novel mutation (T65P) in the PAS domain of the human potassium channel HERG results in the long QT syndrome by trafficking deficiency. J Biol Chem. 2002;277: 48610-48616.

83. Paulussen AD, Jongbloed RJ, Cohen N, Raes A, Snyders DJ, Wilde AA, Smeets H, Aerssens J. Characterization of novel mutations E698X and P872fs877 in the C-terminus of the human potassium channel (HERG that cause the long QT syndrome. Manuscript in preparation.

84. Piippo K, Swan H, Pasternack M, Chapman H, Paavonen K, Viitasalo M, Toivonen L, Kontula K. A founder mutation of the potassium channel KCNQ1 in long QT syndrome: implications for estimation of disease prevalence and molecular diagnostics. J Am Coll Cardiol. 2001;37:562-568.

85. Tranebjaerg L, Bathen J, Tyson J, Bitner-Glindzicz M. Jervell and Lange-Nielsen syndrome: a Norwegian perspective. Am J Med Genet. 1999;89:137-146.

86. Duggal P, Vesely MR, Wattanasirichaigoon D, Villafane J, Kaushik V, Beggs AH. Mutation of the gene for IsK associated with both Jervell and Lange Nielsen and Romano- Ward forms of Long-QT syndrome. Circulation. 1998;97:142-146.

87. Wilde AA, Jongbloed RJ, Doevendans PA, Duren DR, Hauer RN, van Langen IM, van Tintelen JP, Smeets HJ, Meyer H, Geelen JL. Auditory stimuli as a trigger for arrhythmic events differentiate HERG-related (LQTS2) patients from KVLQT1-related patients (LQTS1). J Am Coll Cardiol. 1999;33:327-332.

88. Conrath CE, Jongbloed RJ, van Langen IM, van Tintelen JP, Hauer RN, Robles de Medina EO, Düren DR, Hoorntje TM, Lubbers U, Doevendans PA, Mannens MA, Geelen JL, Smeets HJ, Wilde AA. Genespecific distribution of cardiac events in LQTS1 and LQTS2. Cardiologie. 1999;6:254-259.

89. Zareba W, Moss AJ, Robinson J, Schwartz PJ, Vincent M, Priori SG, Benhorin J, Locati EH, Towbin JA, Keating MT, Lehmann MH, Hall J, Napolitano C, Andrews M, Zhang L, Timothy K. Lethality of Cardiac Events in LQTS Families by Genotype. PACE. 1998;21:850.

90. Zareba W, Moss AJ, Schwartz PJ, Vincent GM, Robinson JL, Priori SG, Benhorin J, Locati EH, Towbin JA, Keating MT, Lehmann MH, Hall WJ. Influence of genotype on the clinical course of the long-QT syndrome. International Long-QT Syndrome Registry Research Group. N Engl J Med. 1998;339:960-965.

91. Moss AJ, Zareba W, Kaufman ES, Gartman E, Peterson DR, Benhorin J, Towbin JA, Keating MT, Priori SG, Schwartz PJ, Vincent GM, Robinson JL, Andrews ML, Feng C, Hall WJ, Medina A, Zhang L. Wang Z. Increased risk of arrhythmic events in long-QT syndrome with mutations in the pore region of the human ether-a-go-go-related gene potassium channel. Circulation. 2002;105:794-799.

92. Tan HL, Alings M, Van Olden RW, Wilde AA. Long-term (subacute) potassium treatment in congenital HERG-related long QT syndrome (LQTS2). J Cardiovasc Electrophysiol. 1999;10:229-233.

93. Mitcheson JS, Chen J, Lin M, Culberson C, Sanguinetti MC. A structural basis for drug-induced long QT syndrome. Proc Natl Acad Sci U S A. 2000;97:12329-2333.

94. Yang P, Kanki H, Drolet B, Yang T, Wei J, Viswanathan PC, Hohnloser SH, Shimizu W, Schwartz PJ, Stanton M, Murray KT, Norris K, George AL Jr, Roden DM. Allelic variants in long-QT disease genes in patients with drug-associated torsades de pointes. Circulation. 2002;105:1943-1948.

95. Napolitano C, Schwartz PJ, Brown AM, Ronchetti E, Bianchi L, Pinnavaia A, Acquaro G, Priori SG. Evidence for a cardiac ion channel mutation underlying drug-induced QT prolongation and lifethreatening arrhythmias. J Cardiovasc Electrophysiol. 2000;11:691-696.

96. Chevalier P, Rodriguez C, Bontemps L, Miquel M, Kirkorian G, Rousson R, Potet F, Schott JJ, Baro I, Touboul P. Non-invasive testing of acquired long QT syndrome: evidence for multiple arrhythmogenic substrates. Cardiovasc Res. 2001;50:386-398.

97. Makita N, Horie M, Nakamura T, Ai T, Sasaki K, Yokoi H, Sakurai M, Sakuma I, Otani H, Sawa H, Kitabatake A. Drug-induced long-QT syndrome associated with a subclinical SCN5A mutation. Circulation. 2002;106:1269-1274. 
98. Sesti F, Abbott GW, Wei J, Murray KT, Saksena S, Schwartz PJ, Priori SG, Roden DM, George AL, Goldstein SA. A common polymorphism associated with antibiotic-induced cardiac arrhythmia. Proc Natl Acad Sci. 2000;97:10613-10618.

99. Berthet M, Denjoy I, Donger C, Demay L, Hammoude H, Klug D, Schulze-Bahr E, Richard P, Funke H, Schwartz K, Coumel P. Hainque B, Guicheney P. C-terminal HERG mutations: the role of hypokalemia and a KCNQ1-associated mutation in cardiac event occurrence. Circulation. 1999:99:1464-1470.

100. Kubota T, Shimizu W, Kamakura S, Horie M. Hypokalemia-induced long QT syndrome with an underlying novel missense mutation in S4-S5 linker of KCNQ1. I Cardiovasc Electrophysiol. 2000;11:1048-1054.

101. Roden DM. Pharmacogenetics and drug-induced arrhythmias. Cardiovasc Res. 2001:50:224-231.

102. Paulussen AD, Gilissen RHJ, Aerssens J, Doevendans PA, Verhasselt P, Schultze-Bahr E, Haverkamp W, Breithardt G, Cohen N, Armstrong M. Genetic susceptibility to acquired long QT syndrome: the impact of congenital long QT genes and drug metabolising enzyme genes. Eur Heart Journal. 2003; submitted.

103. Makkar RR, Fromm BS, Steinman RT, Meissner MD, Lehrman MH. Female gender as a risk factor for torsades de pointes associated with cardiovascular drugs. JAMA. 1993:270:2590-2597.

104. Lehmann MH, Hardy S, Archibald D, Quart B, MacNeil DJ. Sex Difference in Risk of Torsade de Pointes With d,I-Sotalol. Circulation. 1996;94:2535-2541.

105. Ackerman MJ, Clapham DE. Ion channels; Basic science and clinical disease. New Engl J Med. 1997;336:1575-1586.

106. Moss AJ, Zareba W, Hall WJ, Schwartz PJ, Crampton RS, Benhorin J, Vincent GM, Locati EH, Priori SG, Napolitano C, Medina A, Zhang L, Robinson JL, Timothy K, Towbin JA, Andrews ML. Effectiveness and limitations of beta-blocker therapy in congenital long-QT syndrome. Circulation. 2000;101:616-623.

107. Moss AJ. The long QT syndrome revisited: current understanding and implications for treatment. Pacing Clin Electrophysiol. 1997;20:2879-2881.

108. Compton SJ, Lux RL, Ramsey MR, Strelich KR, Sanguinetti MC, Green LS, Keating MT, Mason JW. Genetically defined therapy of inherited long-QT syndrome. Correction of abnormal repolarization by potassium. Circulation. 1996;94:1018-1022.

109. Itoh T, Kikuchi K, Odagawa Y, Takata S, Yano K, Okada S, Haneda N, Ogawa S, Nakano O, Kawahara Y, Kasai H, Nakayama T, Fukutomi T, Sakurada H, Shimizu A, Yazaki Y, Nagai R, Nakamura Y, Tanaka T. Correlation of genetic etiology with response to beta-adrenergic blockade among symptomatic patients with familial long-QT syndrome. J Hum Genet. 2001;46:38-40.

110. Conrath CE, Wilde AA, Jongbloed RJ, Alders M, van Langen IM, van Tintelen JP, Doevendans PA, Opthof T. Gender differences in the long QT syndrome: effects of beta-adrenoceptor blockade. Cardiovasc Res. 2002;53:770-776.

111. Vincent $\mathrm{GM}$. The molecular genetics of the long QT syndrome: genes causing fainting and sudden death. Annu Rev Med. 1998;49:263-274.

112. Crampton R. Preeminence of the left stellate ganglion in the long Q-T syndrome. Circulation. 1979;59:769-778.

113. Schwartz PJ, Locati EH, Moss AJ, Crampton RS, Trazzi R, Ruberti U. Left cardiac sympathetic denervation in the therapy of congenital long QT syndrome. A worldwide report. Circulation. 1991;84:503-511.

114. Rashba EJ, Zareba W, Moss AJ, Hall WJ, Robinson J, Locati EH, Schwartz PJ, Andrews M. Influence of pregnancy on the risk for cardiac events in patients with hereditary long QT syndrome. LQTS Investigators. Circulation. 1998;97:451-456. 



\section{GENETIC BACKGROUND IN LQTS PATIENTS}

Novel KCNQ1 and HERG missense mutations in Dutch Long-QT families

R.J.E. Jongbloed, A.A.M. Wilde, J.L.M.C. Geelen, P.A.F.M. Doevendans, C. Schaap, I. van Langen, J.P. van Tintelen, J.M. Cobben, G.C.M. Beaufort-Krol, J.P.M. Geraedts and H.J.M. Smeets

Human Mutation 13:301-310 (1999) 


\section{Abstract}

Congenital Long-QT Syndrome (cLQTS) is electrocardiographically characterized by a prolonged QT-interval and polymorphic ventricular arrhythmias (torsade de pointes). These cardiac arrhythmias may result in recurrent syncopes, seizure or sudden death. The LQTS can occur either as an autosomal dominant (Romano Ward) or as an autosomal recessive disorder (Jervell and Lange-Nielsen syndrome). Mutations in at least five genes have been associated with the LQTS. Four genes, encoding cardiac ion channels, have been identified. The most common forms of LQTS are due to mutations in the potassium channel genes KCNQ1 and HERG. We have screened 24 Dutch LQTS families for mutations in KCNQ1 and HERG. Fourteen missense mutations were identified. Eight of these missense mutations were novel: three in KCNQ1 and five in HERG. Novel missense mutations in KCNQ1 were Y184S, S373P and W392R and novel missense mutations in HERG were A558P, R582C, G604S, T613M and F640L. The KCNQ1 mutation G189R and the HERG mutation R582C were detected in two families. The pathogenicety of the mutations was based on the segregation in families, the absence in control individuals, the nature of the amino acid substitution and the localization in the protein. Genotype-phenotype studies indicated that auditory stimuli as trigger of cardiac events differentiate LQTS2 and LQTS1. In LQTS1 exercise was the predominant trigger. In addition a number of asymptomatic gene defect carriers were identified. Asymptomatic carriers are still at risk to develop life threatening arrhythmias, underlining the importance of DNA analyses for unequivocal diagnosis of patients with LQTS.

\section{Introduction}

Congenital familial Long QT syndrome (cLQTS) can occur either as an autosomal dominant or as an autosomal recessive disorder (respectively, Romano Ward and Jervell and Lange-Nielsen syndrome; OMIM 220400). Both syndromes are characterized by a prolonged QT-segment on the standard 12 lead electrocardiogram and polymorphic ventricular arrhythmias known as torsade de pointes [1-3]. These arrhythmias often occur in relation to exercise or emotional stress and may result in recurrent syncope, seizures or sudden cardiac death [4]. In addition to the prolonged QT interval the Jervell and Lange-Nielsen syndrome is associated with bilateral sensorineural deafness [5].

The Long-QT syndrome is a genetically heterogeneous disease with 5 loci mapped (LQT 1-5) and 4 genes identified. As families have been described unlinked to these loci, other chromosomal locations must exist [6]. Pathogenic mutations in the potassium channel gene KCNQ1 (previously named KVLQT1; OMIM 192500) on chromosome 11p15.5 [7], Human Eag Related Gene (HERG; OMIM 152427) on chromosome 7q35-36 
[8] and the potassium channel regulatory gene KCNE1 (minK; OMIM 176261) on chromosome 21q22.1-22.2 [9, 10] were identified in LQT1, LQT2 and LQT5 families, respectively. A sodium channel gene SCN5A (OMIM 600163) located on chromosome 3p21-24 is associated with LQT3 [11]. An as yet unidentified gene, located on chromosome 4q23-24, is associated with LQT4 (OMIM 600919) [12]. Genes involved in cLQTS encode proteins which form (part of) ion channels. These ion channels have distinct functions in the regulation of cardiac action potential duration. Mutations in the potassium channel genes KCNQ1, HERG and the accessory subunit KCNE1 lead to a loss of channel function which diminishes the $\mathrm{K}+$ current resulting in a prolonged action potential duration. Mutations in the sodium channel gene SCN5A affect the inactivation rate of the channel resulting in an increased $\mathrm{Na}+$ current and a prolonged action potential duration. Mutations in all four genes can result in the Romano Ward syndrome. The Jervell and Lange-Nielsen syndrome has only been associated with mutations in the KCNQ1 and/or KCNE1 genes [10, 13-16]. The clinical diagnosis of the LQTS can be difficult, due to the incomplete penetrance and variable clinical manifestations of the syndrome. Asymptomatic patients and gene defect carriers with normal or borderline QTc values (QTC=QT corrected for heart rate using Bazett formula) are not uncommon in LQTS families. Untreated LQTS has a 10-year mortallity of $50 \%$ [17]. Cardiac arrest can be the first symptom (in up to $10 \%$ of the affected children) $[18,19]$. Moreover cardiac arrest may occur in $4 \%$ of LQTS family members without a prolonged QT interval [17]. In addition recently a very mild mutation in KCNQ1 has been described, which only becomes manifest (Romano Ward syndrome) in the homozygous state [20]. Therefore it is of clinical importance to identify both the genetic defect and the carriers in a family.

A group of 24 Dutch Long QT index patients and families was studied to identify the genetic defects for LQT1-5. If the family was large enough we used linkage analysis to identify the locus involved or to exclude the other loci. Because the majority mapped to the LQT1 or LQT2 locus, we performed mutation analysis in the KCNQ1 and HERG genes. Here we report 7 KCNQ1 mutations, of which 3 have not been described previously and 5 novel HERG mutations, accounting for the disease in 14 of the 24 LQTS families. The pathogenicity of the mutations was established by genetic analyses. Genotype-phenotype studies were performed to analyse the impact of the mutations identified.

\section{Subjects and Methods}

\section{LQTS patients}

Patients were selected for genetic screening using criteria according to Schwartz et al [4]. All LQTS index patients had an abnormal standard electrocardiogram (ECG) with prolonged QTC values $>440 \mathrm{msec}$. Syncopes were common and sudden cardiac death 
occurred in some families, most often in relation to either physical or emotional stress and sometimes after an auditory trigger (Table 1). None of the patients had hearing problems and the segregation pattern in the familial cases was autosomal dominant. Linkage or the triggers for arrhythmias were used as criteria to select the gene most likely involved: physical stress for LQT1, acoustic trigger for LQT2 [21] and prolonged QTc without physical stress for LQT3. If no indication for the involvement of LQT1, 2 or 3 locus was found, the LQT5 gene (KCNE1) was amplified and directly analysed by sequencing.

\section{Haplotyping}

Genomic DNA was extracted from peripheral blood lymphocytes by the high salt extraction method [22]. DNA haplotyping for loci LQT1-4 was performed by using a set of 10 polymorphic microsatellite markers as described in detail by van den Berg et al. [23] and included: D11S1318, TH01, D11S860 (LQT1); D7S483 and D7S636 (LQT2); D3S1298 and D3S1100 (LQT3) and D4S193, D4S406 and D4S402 (LQT4). Primer sequences were derived from the Genome Database (GDB). For microsatellite analysis the forward primers were 5 ' labeled with fluorochromes HEX, TET or 6-FAM. DNA fragments were amplified by the PCR reaction according to procedures optimized for analysis on the ABI-377 automatic sequencer using gene-scan software 2.0 (Perkin Elmer). Two intragenic polymorphic sites in HERG were used as additional markers in linkage analysis. Primer set $3 \mathrm{~L}$ and 8 R for S3 (1489) and primer set 5L and 11R for S5 (L564) were used for SSCP polymorphism [8].

\section{Mutation screening}

Genomic fragments coding for the six transmembrane domains and the pore region of the KCNQ1 gene were amplified using the primer sets described by Wang et al [7]. The S1-S6 regions, the pore region and the nucleotide binding domain (NBD) of HERG were amplified by PCR using primer sets according to Curran et al [8]. Additional PCRs were developed to amplify the S4S5 region (primer set $4 \mathrm{~L}$ and $10 \mathrm{R}$ ), the S1S2S3 region (356 bp, primer set $1 L-9 R$ ) and the S4S5poreS6 region (449 bp, primer set 4L-12R) of HERG. Using primer set $15 \mathrm{~L}$ and $17 \mathrm{R}$ an intron, disrupting the NBD coding region in HERG, of approximately 1000 bp was amplified. An intron primer int9F (primer sequence: 5 ' CCC-CGG-GGC-TGA-GCT- CCC-TGT-C 3') was used in combination with primer $17 R$ to generate a 191 bp PCR product of the terminal part of the NBD region in HERG. PCR conditions: $100 \mathrm{ng}$ forward and reverse primer, $0.2 \mathrm{mM}$ deoxyribonucleotides, $1 \mathrm{U}$ Taq DNA polymerase (Life Technologies), $1.5 \mathrm{mM} \mathrm{MgCl}$, and $100 \mathrm{ng}$ genomic DNA (volume $50 \mathrm{ul}$ ). The coding region of KCNE1 was amplified by PCR using primer sets as described by Splawski et al [26]. 
Table 1. KCNQ1 and HERG mutations in Dutch LQTS families

\begin{tabular}{|c|c|c|c|c|c|c|c|}
\hline $\begin{array}{l}\text { Family } \\
\text { number }\end{array}$ & $\begin{array}{l}\text { Familial Sudden death } \\
\text { /trigger of syncope }\end{array}$ & Gene & Domain & $\begin{array}{l}\text { Mutation } \\
\text { codon }{ }^{1}\end{array}$ & $\begin{array}{c}\text { Family } \\
\text { Members } \\
\text { tested }\end{array}$ & Carriers & $\begin{array}{l}\text { Asympt. } \\
\text { carriers }\end{array}$ \\
\hline 2164 & $\begin{array}{l}\text { One child died at age } 6 \text { in } \\
\text { swimming pool/ } \\
\text { emotion; physical stress }\end{array}$ & KCNQ1 & $\mathrm{S}_{2} \mathrm{~S}_{3}$ & $Y_{184 S}$ & 22 & 10 & 5 \\
\hline 1597 & $\begin{array}{l}\text { One person died at age } 28 \\
\text { physical stress/ playing } \\
\text { soccer }\end{array}$ & KCNQ1 & $\mathrm{S}_{2} \mathrm{~S}_{3}$ & G189R & 37 & 17 & 2 \\
\hline 1855 & $\begin{array}{l}\text { No sudden death/ } \\
\text { physical stress }\end{array}$ & KCNQ1 & $\mathrm{S}_{2} \mathrm{~S}_{3}$ & G189R & 5 & 3 & 1 \\
\hline 2814 & $\begin{array}{l}\text { No sudden death/ } \\
\text { physical stress; } \\
\text { swimming pool }\end{array}$ & KCNQ1 & pore & G314S & 3 & 2 & - \\
\hline 2379 & $\begin{array}{l}\text { No familial history; de } \\
\text { novo mutation; physical } \\
\text { stress }\end{array}$ & KCNQ1 & pore & Y315S & 3 & 1 & - \\
\hline 1538 & $\begin{array}{l}\text { One person died at age } 6 \\
\text { /physical stress }\end{array}$ & KCNQ1 & S6 & $G_{345 R^{2}}$ & 8 & 5 & - \\
\hline 2362 & $\begin{array}{l}\text { Two children died in } \\
\text { swimming pool at age } \\
51 / 2 \text { and } 8 / \text { physical } \\
\text { stress }\end{array}$ & KCNQ1 & $\begin{array}{l}\text { distal to } \\
\mathrm{S} 6\end{array}$ & S373P & 11 & 7 & 1 \\
\hline 1669 & $\begin{array}{l}\text { No sudden death/ } \\
\text { physical stress, } \\
\text { swimming pool, } \\
\text { emotion }\end{array}$ & KCNQ1 & $\begin{array}{l}\text { distal to } \\
\text { S6 }\end{array}$ & W392R & 8 & 5 & 3 \\
\hline 1602 & $\begin{array}{l}\text { One person died before } \\
\text { age } 40 \text { after arousal/ } \\
\text { acoustic }\end{array}$ & HERG & S5 & A558P & 15 & 3 & - \\
\hline 1599 & $\begin{array}{l}\text { One person died during } \\
\text { sleep at age } 27 / \text { acoustic }\end{array}$ & HERG & $\begin{array}{l}\text { loop \$5 } \\
\text { pore }\end{array}$ & R582C & 11 & 6 & 4 \\
\hline 1656 & $\begin{array}{l}\text { No sudden death/ } \\
\text { acoustic }\end{array}$ & HERG & $\begin{array}{l}\text { loop } 55 \\
\text { pore }\end{array}$ & R582C & 8 & 4 & 2 \\
\hline 2270 & $\begin{array}{l}\text { No sudden death/ } \\
\text { acoustic }\end{array}$ & HERG & $\begin{array}{l}\text { loop \$5 } \\
\text { pore }\end{array}$ & G604S & 1 & 1 & - \\
\hline 2475 & $\begin{array}{l}\text { Father died during sleep. } \\
\text { Brother died before age } \\
\text { 40/Acoustic }\end{array}$ & HERG & pore & T613M & 1 & 1 & - \\
\hline 2148 & $\begin{array}{l}\text { Uncle +aunt died before } \\
41 . \text { Sister died at age } \\
18 / \text { acoustic }\end{array}$ & HERG & S6 & $\mathrm{F} 640 \mathrm{~L}$ & 1 & 1 & - \\
\hline
\end{tabular}

${ }^{1} \mathrm{KCNQ} 1$ codon numbering was according to sequence Yang et al [24] and Chouabe et al [25]. Genebank accession numbers: AFO00571 and U86146. HERG codon numbering was based on sequence Genebank accession number: U04270. ${ }^{2}$ published by van den Berg et al [23] 

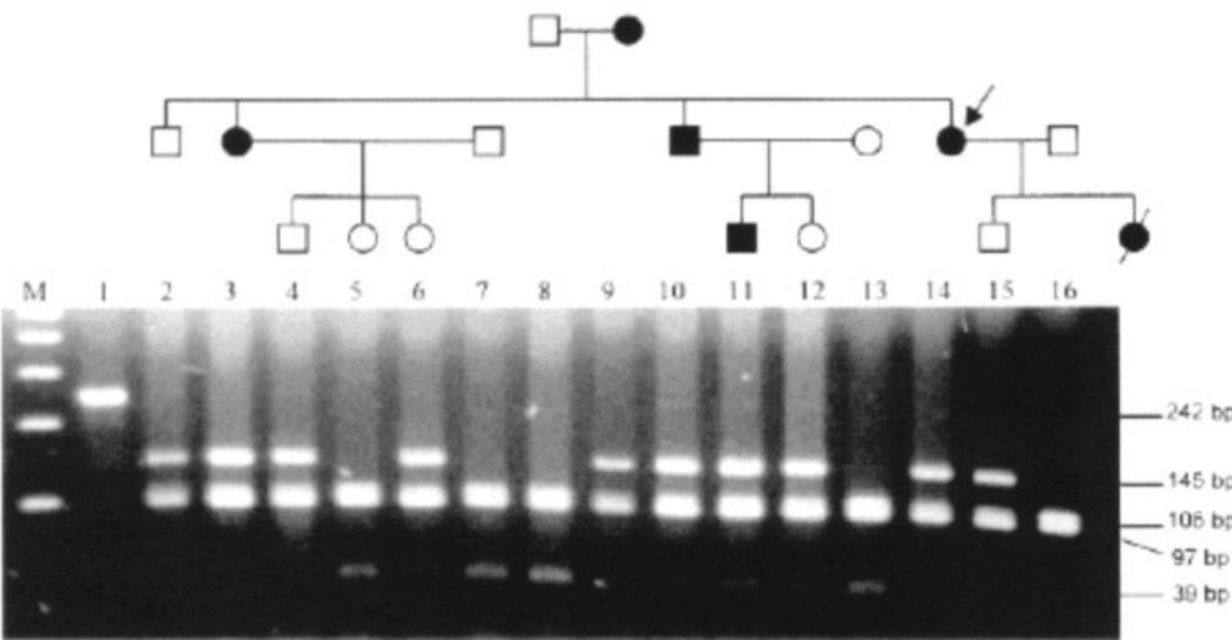

Figure 1. Rsa I restriction analysis of the $\mathrm{Y}_{1845}$ missense mutation in S2S3 region of KCNQ1. The A->C mutation results in loss of a Rsal restriction site. Mutation carriers show an additional fragment of 145 bp on Nusieve-agarose gel 2:1. Asymptomatic carriers in lane 2, 4, 6, 12 and 15 (age 44, 19, 14, 9 and 9; QTc values at rest were resp. $455,450,465,457$ and $468 \mathrm{msec}$ ). The undigested PCR product $242 \mathrm{bp}$ is

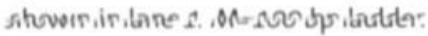

PCR fragments were screened for single-strand conformation polymorphism (SSCP) using the genePhor system (Pharmacia) and GeneGel Excell gels 12,5/24. Gels were run at $5^{\circ} \mathrm{C}$ and $15^{\circ} \mathrm{C}$ according to manufacturers recommendations. The gels were silver stained (Pharmacia PlusOne kit using an automatic stainer) and air dried. Amplified products with aberrant SSCP bands were purified with a PCR purification kit (Qiagen). The purified PCR products were sequenced with both amplification primers, forward and reversed, using the Dye Terminator Cycle sequencing Kit (Perkin Elmer) and analysed on an $\mathrm{ABI}-377$ sequencer. Some fragments were sequenced directly without prior SSCP analysis.

\section{Tests for specific mutations}

\section{R582C mutation in HERG.}

We used primer $12 R$ and mismatch primer $R 582 \mathrm{CmmF}^{2}$ (primer sequence $5^{\prime}$ GAGCAGCCACACACATGGACGCA 3') to generate a PCR product. This mismatch primer generates a Sphl restriction site if the mutation C $\rightarrow T$ (R582C) is present (PIRA=primer induced restriction analysis). Incubation of the PCR product with Sphl endonuclease results in fragments of 245 bp (wild type) and 225 bp +20 bp (mutant). The bold sequence is the generated Sphl site 5'-GAGCAGCCACACA TGGACGCATGCAT-3' 


\section{HERG S6 polymorphism Y652.}

A 561 bp fragment, containing the region S6-intron-S6, was generated by PCR using primer set $6 \mathrm{~L}$ and $13 \mathrm{R}[8]$. After Rsal endonuclease incubation the product was analyzed on a Nusieve Agarose gel 2:1. Frequency of the T/C polymorphism is 0.47 [27].

\section{Results}

A total of 24 unrelated LQTS patients and families were available for DNA analysis. In $50 \%(12 / 24)$ of the LQTS families, linkage analysis could be performed and in these families a role for either locus LQT1 or LQT2 was likely (data not shown). The other families were either too small, affected family members had died or the clinical data were not complete. Mutation analysis was performed in KCNE1 and in either the KCNQ1 gene or HERG, as established by linkage or in both, if the data were inconclusive. The pathogenicity of novel mutations was based on the location of the substitution, the evolutionary conservation of the altered amino acid in related $\mathrm{K}+$ ion channel proteins of different species, the segregation with the disease in the family and finally, by the absence of the mutation in 55 healthy control individuals.

\section{Mutation analysis of the KCNO1-gene}

The six transmembrane spanning segments including the pore region of the KCNQ1 gene were screened by SSCP. We found different aberrant SSCP conformers in eight different index patients, three in region $\mathrm{S}_{2} \mathrm{~S} 3$, three in the pore forming region S5-pore-\$6 and two in the intracellular region distal to $\$ 6$. All resulted from missense mutations, four of them had been reported previously.

Family 2164 was analysed after the sudden death of a six year old girl while diving in a swimming pool. Linkage analysis excluded the LQT2 and LQT3 loci. In this family a novel missense mutation was found in the $\mathrm{S}_{2} \mathrm{~S} 3$ region. The mutation results in loss of a Rsal restriction site (Fig. 1). By screening all available family members for the $\mathrm{Y} 184 \mathrm{~S}$ mutation, nine additional carriers were identified. Five carriers, 3 male and 2 female, were asymptomatic and one of the carriers did not show QTC prolongation. In family 1597 and family 1855 an identical missense mutation G189R was found. This missense mutation located in the S2S3 region was published previously by Wang et al [7] as G60R. Genealogical research demonstrated that these two families had a common ancestor six generations ago $( \pm 1780)$. Family 1597 was a large family with 37 members. In this family 17 carriers of the G189R mutation were identified. Carriers showed mild phenotypes with (sometimes borderline) prolonged QT values after physical stress, although one exercise related sudden cardiac death occurred. In family 2814 we could identify the mutation G314S. A de novo mutation Y315S was found in family 2379. The child had clinical symptoms during physical stress and emotion. Both parents were not 
affected and non paternity was excluded by testing a set of highly polymorphic markers (data not shown). The mutation G314S as well as the mutation Y315S were previously reported by Donger et al. 1997 in two French families. Finally we found two novel missense mutations S373P and W392R in family 2362 and family 1656 . These mutations are located in the intracellular part of the ion channel, distal to the S6 transmembrane spanning region. Seven gene defect carriers in family 2362 showed QTc values ranging from 422 to $540 \mathrm{msec}$ (at rest). One of these seven carriers did not show a prolonged QTc value, but he was using $\beta$-blockers for many years. In this family two children (age $5 \frac{1}{2}$ and 8 ) died in a swimming pool while diving. In family 1656 all children ( 3 male and 1 female) inherited the maternal gene defect. The mother (QTc $452 \mathrm{msec}$ ) had no specific clinical complaints. Two of her children (QTc 503 and 450 $\mathrm{msec}$ ) showed clinical symptoms during physical stress (in a swimming pool) and emotion, respectively, and two did not show clinical symptoms (QTC 518 and 475 $\mathrm{msec}$ ). The reported QTc values were determed at rest.

Table 2. Evolutionary conservation of substituted amino acids in HERG

\begin{tabular}{lllccccc}
\hline Species & & $\begin{array}{l}\text { Genbank } \\
\text { number }\end{array}$ & A558P & R582C & G6045 & T613M & F640L \\
\hline 1. Homo sapiens & Erg & U04270 & A & R & G & T & F \\
2. Mus Musculus & Erg & AF016192 & A & H & G & T & F \\
3. Rattus Norvegicus & Erg- & U42204 & A & K & G & T & F \\
4. Rattus Norvegicus & Erg- & AF016191 & A & K & G & T & F \\
5. Rattus Norvegicus & Elk-1 & Al007628 & A & L & G & T & F \\
6. Rattus Norvegicus & Elk-2 & Al007627 & A & E & G & T & F \\
7. D. Melanogaster & Eag & M61157 & M & Q & G & T & F \\
8. D. Melanogaster & Erg & Q02280 & I & N & G & T & F \\
\hline
\end{tabular}

Similar to KCNQ1 we screened the six transmembrane spanning regions including the pore and the putative nucleotide binding domain (NBD) of HERG, using primers sets as described by Curran et al [8]. Because not all intron sequences were available to generate PCR primers, we started amplifying and sequencing the small 328 bp intron, that disrupts the $S 6$ spanning region of HERG, with primers $6 \mathrm{~L}$ and $13 R$. For screening the nucleotide binding domain, which is also interrupted by an intron, a new forward primer (intron 9F) was designed. Six missense mutations were identified. The pathogenicity of the novel HERG missense mutations were based on the location of the substitution, the evolutionary conservation (Table 2) of the altered amino acid in related $\mathrm{K}+$ ion channel proteins of different species, the segregation with the disease in the family and finally, by the absence of the mutation in 55 healthy control individuals.

\section{Mutation analysis of HERG}

Family 1602 was initially misdiagnosed and treated for epilepsy. A young woman (age 22) died suddenly upon arousal from sleep by an alarm clock. We found an aberrant 
SSCP pattern in region S4S5. The SSCP pattern was rather complex due to the additional A-> G polymorphism (L564) in the S5 domain of HERG. This silent mutation in the S5 region was only 20 bp away from the novel A558P missense mutation. A loss of a Hhal restriction site, generated by the novel missense mutation, was used to screen family members. Only one person in generation II was carrier of the A558P mutation, although some of his brothers and sisters shared the same haplotype (Fig. 2).This strongly suggests that the mutation was de novo. Family 2148 (Surinam background) and family 2475 were individual gene carriers directly analyzed for HERG mutations as the trigger for their arrhythmias (auditory stimuli) and the ECG were indicative for the LQT2 locus [21].

Several families linked to the HERG locus by haplotyping did not show aberrant conformers by SSCP analysis. Therefore, the transmembrane segments were sequenced to test whether we had missed mutations. Using this strategy two additional missense mutations in three families were identified. In two apparently unrelated families, family 1599 and family 1656 we identified a new missense mutation R582C. This mutation did not result in an aberrant SSCP with any combination of primers used in this study. Therefore a mismatch primer was designed to prove the mutation by generating a restriction site. In the families 10 carriers were identified, of which 6 were asymptomatic carriers (no clinical symptoms). In family 2270 the G604S was at first not detected by SSCP analysis, as the mutation was located within primer binding site $6 \mathrm{~L}$, initially used to generate a PCR product for SSCP analysis. By using a different primer $1883 \mathrm{~F}$, located 6 bp 3 ' to the $\mathrm{S} 5$ polymorphism, the mutation could easily be detected by SSCP analysis.

\section{Discussion}

Since the recognition that the KCNQ1 (KVLQT1) and HERG genes were involved in CLQT syndrome, many mutations in these two genes have been published. Together with the SCN5A and KCNE1 gene they form a group of transmembrane proteins involved in cardiac ventricular repolarization. An abnormal repolarization rate is the main cause of ventricular arrhythmias known as torsade de pointes leading to syncope and occasionaly sudden cardiac death. A gene described in a single French LQTS family and linked to chromosome 4 (LQT4) is still unknown. Until now $42 \operatorname{KVLQT1}[28,29,30]$ and 24 pathogenic mutations in HERG (Table 3 ) have been described. As suggested by Curran et al. [8] and Wang et al. [7] mutations in the genes KCNQ1 and HERG are the most prevalent in families with CLOT syndrome, which is supported by the linkage data in our families. Therefore we have focused on genetic analysis of these two genes. In 14 LQTS families we have identified 12 different missense mutations, eight of which have not been described before. The pathogenicity of the mutations was based on genetic criteria. In five families with linkage to either the LQT1 or the LQT2 locus, no mutations were found as yet. These mutations may be present in exons which have 
not been screened, or in introns or regulatory sequences.

In two families we found an identical missense mutation G189R in KCNQ1. In our case, a common ancestor was likely by genealogical studies. This mutation has been described by Wang et al [7]. The novel missense mutation Y184S is located within the same $S_{2} S_{3}$ area as the G189R mutation in KCNQ1. In this family 8 carriers were identified of which 5 were asymptomatic and 1 did not show an increased QT interval. Mutations in the region $\mathrm{S}_{2} \mathrm{~S}_{3}$ have in general been associated with a less severe phenotype than mutations in the S4S5 loop and pore domain [28]. However, one has to be careful in drawing conclusions for individual patients, as examplified by the death of a 6 year old girl (while diving in a swimming pool) from a family with the Y184S mutation.

A de novo mutation $\mathrm{Y} 315 \mathrm{~S}$ and a missense mutation G314S were found in the pore region of KCNQ1. Identical missense mutations have been reported in two French families by Donger et al [28]. These patients, comparable to our patient, had their first syncope before age of 10 . This missense mutation is associated with a high risk of sudden death if untreated. De novo mutations in LQTS were previously reported for HERG [8]. The novel missense mutations S373P and W392R occurred in highly

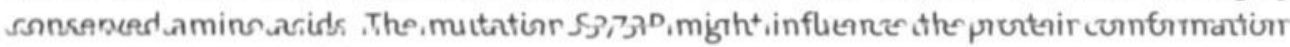
due to the change of the amino acid serine into the more rigid proline which has the ability to disrupt alpha helixes. In case of the W392R mutation, the hydrophobic amino acid tryptophan changes into the strong basic and hydrophylic arginine. Mutations in this intracellular part of the ion channel distal to $\$ 6$ were described by several authors $[28,31]$.

In contrast to the KCNQ1 mutations, the HERG mutations reported in this study were exclusively found in the pore forming regions. Some of the previously reported HERG mutations have been tested in physiological experiments. Similar physiological properties might be expected if comparable amino acid substitutions occur in the same region. The A558P mutation is located in the vicinity of the A561V and A561T [8, 31, 32]. Sanguinetti et al [33] and Smith et al [34] reported a strong dominant negative effect in a cotransfection study of the A561V missense mutation and wild type HERG. The novel missense mutation R582C is located in the extracellular loop between S5 and the pore forming unit. Although the arginine at codon 582 is not a well conserved amino acid, the substitution to a cysteine may result in conformational changes and loss of function due to the formation of disulfide bonds. A novel missense mutation $T 613 \mathrm{M}$ is located in an area where missense mutations occur frequently, like $\mathrm{Y} 611 \mathrm{H}$, V612L and $\mathrm{A} 614 \mathrm{~V}[31,38]$. 


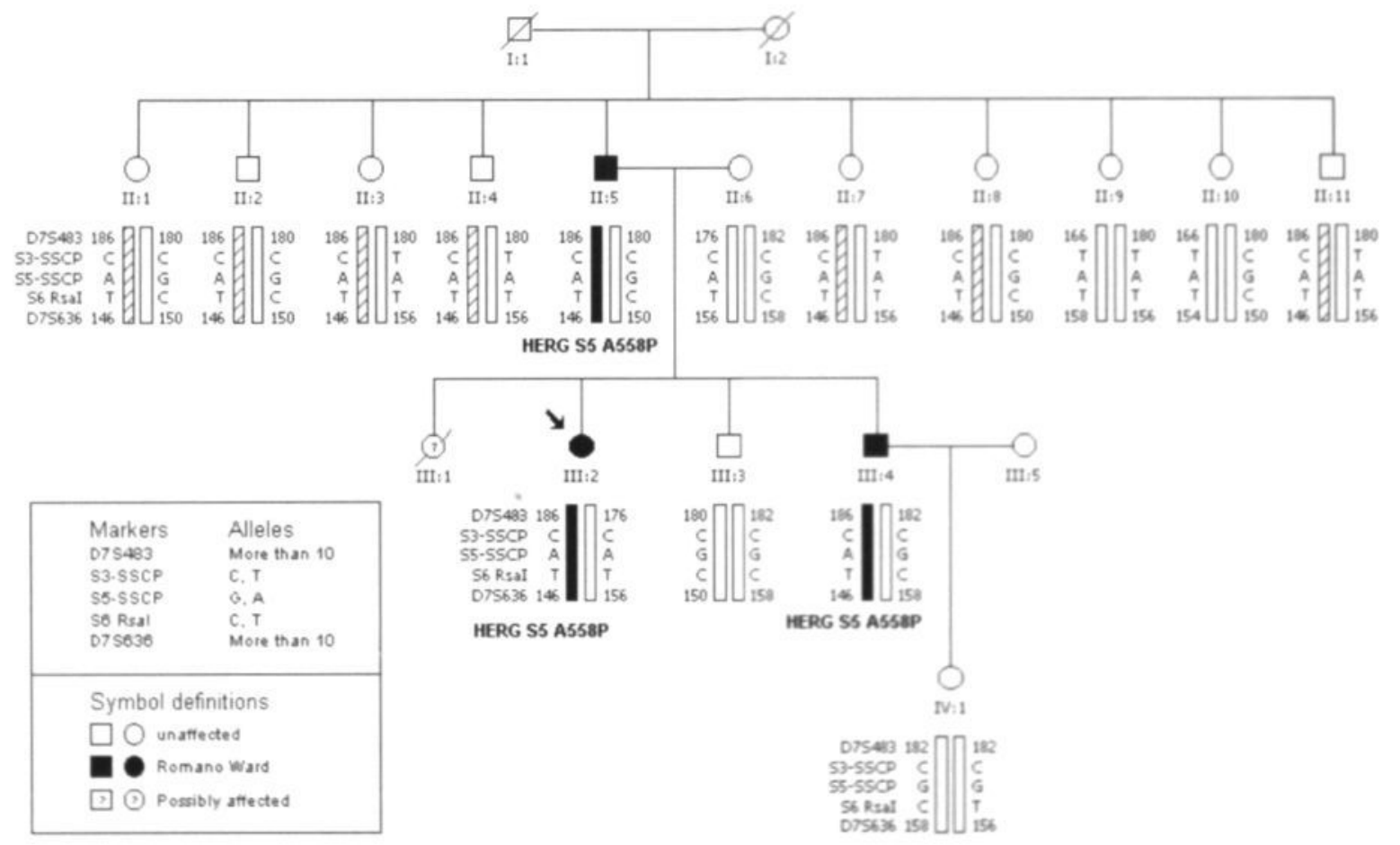

Figure 2. Pedigree structure and linkage analysis of family 1602 . The risk haplotype with the A558P mutation is indicated by a black bar, the risk haplotype without this mutation by a dashed bar. Most likely the mutation originated in individual II-5. 
Table 3 Summary of HERG mutations

\begin{tabular}{|c|c|c|c|c|c|c|}
\hline Codon & Region & Exon & Location $^{1}$ & Mutation & Reference & Remarks \\
\hline del 1261 & S1 & 6 & 1261 & $1 \mathrm{bp}$ del $\mathrm{A}$ & Curran et al $[8,35]$ & truncated protein \\
\hline N470D & S2 & 6 & 1408 & aac->gac & Curran et al [8] & \\
\hline T474I & loop \$2-S3 & 6 & 1421 & acc->atc & Tanaka et al [31] & $\begin{array}{l}\text { prot. A, } \\
\text { phosphorylation } \\
\text { site }\end{array}$ \\
\hline 1489 & loop S2-53 & 6 & 1476 & atc->att & Curran et al [8] & polymorphism $37 \%$ \\
\hline Y493X & loop S2-S3 & 6 & 1488 & $\operatorname{tac}->\operatorname{tag}$ & Itoh et al [36] & \\
\hline $\begin{array}{l}\text { del I500- } \\
\text { F508 }\end{array}$ & $\mathrm{S}_{3}$ & 6 & 1498 & $27 \mathrm{bp}$ del & Curran et al [8] & \\
\hline F513 & S3 & 6 & 1539 & $\mathrm{ttc}->\mathrm{ttt}$ & Schulze-Bahr [27] & polymorphism $47 \%$ \\
\hline R534C & S4 & 7 & 1599 & $\operatorname{cgc} c>\operatorname{tg} c$ & Itoh et al [36] & \\
\hline A558P & S5 & 7 & 1671 & $g c g->c c g$ & This study & \\
\hline A561T & S5 & 7 & 1681 & gcg->acg & Dausse et al [32] & \\
\hline A561V & S5 & 7 & 1682 & gcg->gtg & $\begin{array}{l}\text { Curran et al [8] } \\
\text { Tanaka et al [31] }\end{array}$ & \\
\hline L564 & S5 & 7 & 1692 & $\mathrm{cta}->\mathrm{ctg}$ & Curran et al [8] & $\begin{array}{l}\text { polymorphism } \\
44 \%\end{array}$ \\
\hline G572C & S5 & 7 & 1714 & $g g c->\operatorname{tgc}$ & Splawski et al [26] & \\
\hline R582C & loop \$5-pore & 7 & 1743 & cgc->tgc & This study & \\
\hline N588D & loop S5-pore & 7 & 1762 & aac->gac & Splawski et al [26] & \\
\hline I593R & loop S5-pore & 7 & 1777 & ata->aga & Benson et al [37] & $\begin{array}{l}\text { change in } \mathrm{K}+ \\
\text { selectivity and } \\
\text { permeability }\end{array}$ \\
\hline S600s & loop S5-pore & 7 & 1799 & $a g c->a g t$ & Satler et al [38] & $\begin{array}{l}\text { cryptic splice site in } \\
\text { frame deletion } 50 \\
\text { AA }\end{array}$ \\
\hline G601S & loop S5-pore & 7 & 1800 & ggc->agc & Akimoto et al [39] & \\
\hline G604S & loop \$5-pore & 7 & 1809 & ggc->agc & This study & \\
\hline $\mathrm{Y} 611 \mathrm{H}$ & pore & 7 & 1831 & tat->cat & Tanaka et al [31] & \\
\hline V612L & pore & 7 & 1833 & gtg->ttg & Satler et al [38] & \\
\hline T613M & pore & 7 & 1837 & acg->atg & This study & \\
\hline $\mathrm{A} 614 \mathrm{~V}$ & pore & 7 & 1840 & gcg->gtg & $\begin{array}{l}\text { Tanaka [31] Satler [38] } \\
\text { and Splawski et al [26] }\end{array}$ & \\
\hline G628S & pore & 7 & 1881 & ggc->agc & Curran et al [8] & de novo mutation \\
\hline N629D & pore & 7 & 1884 & aac->gac & Satler et al [38] & \\
\hline N629S & pore & 7 & 1885 & aac->agc & Satler et al [38] & \\
\hline V630L & pore & 7 & 1888 & gtc- $>$ ctc & Tanaka et al [31] & \\
\hline V630A & pore & 7 & 1889 & gtc->gcc & Splawski et al [26] & \\
\hline N633S & pore & 7 & 1898 & aac->agc & Satler et al [38] & \\
\hline $\mathrm{F} 640 \mathrm{~L}$ & \$6 & 7 & 1919 & $\mathrm{ttc}->\mathrm{tta}$ & This study & \\
\hline $\begin{array}{l}\text { M651 del } \\
\text { AT }\end{array}$ & \$6 & 8 & 1950-1951 & 2 bp del at & Itoh et al [36] & frameshift \\
\hline Y652 & S6 & 8 & 1956 & tat->tac & Schulze-Bahr [27] & $\begin{array}{l}\text { polymorphism } \\
22 \%\end{array}$ \\
\hline Q725X & S6 & 9 & 2172 & cag->tag & Itoh et al [36] & \\
\hline Int9-3nt & NBD & Intron 9 & 2398-3nt & $g->c$ & Curran et al [8] & \\
\hline $\mathrm{V} 822 \mathrm{M}$ & NBD & 10 & 2463 & gtg->atg & Satler et al [40] & \\
\hline $\begin{array}{l}\text { E847/E857 } \\
\text { del }\end{array}$ & NBD-ter & 10 & $2539-2569$ & 31 bp dup & Itoh et al [36] & frameshift \\
\hline
\end{tabular}

' A of the ATG start codon is nucleotide position 1(Genebank accession number U04270) 
The missense mutations $\mathrm{T} 613 \mathrm{M}$ and $\mathrm{A} 614 \mathrm{~V}$ are situated in a CpG sequence, which are known as mutational sensitive spots due to deamination of 5 methylcytosine at the CpG dinucleotides. Finally, the novel missense mutation T640L is located in the terminal part of the pore region (outermouth) and is a highly conserved amino acid in different species. Although the functional effect of this mutation has not been determined, physiological tests demonstrate that mutations in this region show an increased inactivation rate and loss of selectivity for $\mathrm{K}+[34]$.

In conclusion a total of 24 Dutch LQTS families were screened for mutations in the KCNQ1 and HERG genes. In 14 families missense mutations were found. In addition a number of asymptomatic gene defect carriers were identified. Asymptomatic carriers are still at risk to develop life threatening arrhythmias, underlining the importance of DNA analysis for unequivocal diagnosis of patients with LQTS.

Acknowledgments. This work was partly supported by a grant from the Dutch Heart Association (NHS 95.014. AAM. Wilde PhD MD) and the ICIN (Interuniversity Cardiology Institute Netherlands).

\section{References}

1. Jervell A, Lange-Nielsen F. Congenital deaf-mutism, functional heart disease with prolongation of the QT interval and sudden death. Am Heart J. 1957; 54:59-68.

2. Romano C. Congenital cardiac arrhythmia. Lancet. 1965;1 658-659.

3. Ward OC. A new familial cardiac syndrome in children. J Irish Med Assoc. 1964:54: 103-106.

4. Schwartz PJ, Moss AJ, Vincent GM, Crampton RS. Diagnostic criteria for the long QT syndrome. An update. Circulation. 1993;88:782-784.

5. Fraser GR, Frogatt P, Murphy T. Genetical aspects of the cardio-auditory syndrome of Jervell and Lange-Nielsen (congenital deafness and electrocardiografic abnormalities). Ann Hum Genet. 1964;28:133-157.

6. Jiang C, Atkinson D, Towbin JA, Splawski I, Lehmann MH, Li H, Timothy K, Taggart RT, Schwartz PJ, Vincent GM, Moss AJ, Keating MT. Two long QT syndrome loci map to chromosomes 3 and 7 with evidence for further heterogeneity. Nature Genet. 1994;8:141-147.

7. Wang Q, Curran ME, Splawski I, Burn TC, Millholland JM, VanRaay TJ, Shen J, Timothy KW, Vincent GM, de Jager T, Schwartz PJ, Towbin JA, Moss AJ, Atkinson DL, Landes GM, Connors TD, Keating MT. Positional cloning of a novel potassium channel gene: KVLQT1 mutations cause cardiac arrhythmias. Nature Genet. 1996;12:17-23.

8. Curran ME, Splawski I, Timothy KW, Vincent GM, Green ED, Keating MT. A molecular basis for cariac arrhythmia: HERG mutations cause long QT syndrome. Cell. 1995;80:795-803.

9. Splawski I, Tristani-Firouzi M, Lehrmann MH, Sanguinetti M, Keating MT. Mutations in the hminK cause long QT syndrome and suppress $I_{\mathrm{bs}}$ function. Nature Genet. 1997; 17:338-340.

10. Splawski I, Timothy K, Vincent G, Atkinson D, Keating M. Molecular basis of the long-QT syndrome associated with deafness. New Eng J Med. 1997;336:1562-1567.

11. Wang Q, Shen J, Splawski I, Atkinson D, Li Zhizhong, Robinson JL, Moss AJ, Towbin JA, Keating MT. SCN5A mutations associated with an inherited cardiac arrhythmia, long QT syndrome. Cell. 1995;80:805-811.

12. Schott JJ, Charpentier F, Peltier S, Foley P, Drouin E, Bouhour JB, Donneley P, Vergnaud G, Bachner L, Moisan JP, Le Marec H, Pascal O. Mapping of a gene for long QT syndrome to chromosome 4q25-27. Am J Hum Genet. 1995; 57:1114-1122. 
13. Duggal P, Vesely MR, Wattanasirichaigoon D, Villafane J, Kaushik V, Beggs AH. Mutation of the gene for IsK associated with both Jervell and Lange Nielsen and Romano- Ward forms of Long-QT syndrome. Circulation. 1998;97:142-146.

14. Neyroud N, Tesson F, Denjoy I, Leibovici M, Donger C, Barhanin J, Fauré S, Gary F, Coumel P, Petit C, Schwartz K, Guicheney P. A novel mutation in the potassium channel gene KVLQT1 causes Jervell Lange-Nielsen cardioauditory syndrome. Nature Genet. 1997;15:186-189.

15. Schulze-Bahr E, Wang Q Wedekind H, Haverkamp W, Chen Q, Sun Y. KCNE1 mutations cause Jervell and Lange-Nielsen Syndrome. Nature Genet. 1997;17:267-268.

16. Tyson J, Tranebjærg L, Bellman S, Wren C, Taylor J, Bathen J, Aslaksen B, Sørland SJ, Lund O, Malcolm S, Pembrey M, Bhattacharya S, Bitner-Glindzicz M. ISK and KvLQT1: mutation in either of the two subunits of the slow component of the delayed rectifier potassium channel can cause Jervell and Lange-Nielsen syndrome. Hum Mol Genet. 1997;12:2179-2185.

17. Moss A. The long QT syndrome Prospective longitudinal study of 328 families. Circulation. 1991;84:1136-1144.

18. Garson A, Dick M, Fournier A, Gilette P, Hamilton R, Kugler J, Van Hare GF, Vetter V, Vick GW. The Long QT Syndrome in Children: An International Study of 287 Patients. Circulation. 1993;87:1866-1872.

19. Zareba W, Moss AJ, Robinson J, Schwartz PJ, Vincent M, Priori SG, Benhorin J, Locati EH, Towbin JA, Keating MT, Lehmann MH, Hall J, Napolitano C, Andrews M, Zhang L, Timothy K. Lethality of Cardiac Events in LQTS Families by Genotype. PACE. 1998;21:850.

20. Priori S, Schwartz P, Napolitano C, Bianchi L, Dennis A, De Fusco M, Brown A, Casari G. A Recessive Variant of the Romano-Ward Long-QT Syndrome? Circulation. 1998;97:2420-2425.

21. Wilde AAM, Jongbloed RJE, Doevendans PA, Düren DR, Hauer RNW, van Langen IM, van Tintelen JP,

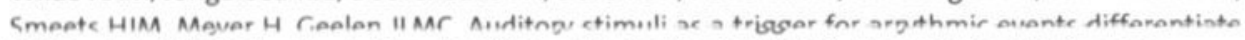

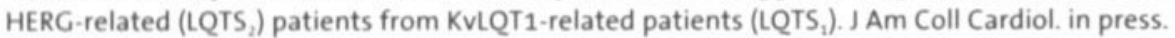

22. Muellerbach R, Lagoda PJL, Welter C. An efficient salt-chloroform extraction of DNA from blood and tissues. Trends in Genetics. 1989;5:391.

23. Van den Berg MH, Wilde AAM, Robles de Medina EO, Meyer H, Geelen LMC, Jongbloed RJE, Wellens HJJ, Geraedts JPM. The long QT syndrome: A novel missense mutation in the S6 region of the KVLQT1 gene. Hum Genet. 1997;100:356-361.

24. Yang WP, Levesque PC, Little WA, Conder ML, Shalaby FY, Blanar MA. KvLQT1, a voltage-gated potassium channel reponsable for human cardiac arrhythmias. Proc Natl Acad Sci USA. 1997;94:4017-4021.

25. Chouabe C, Neyroud N, Guicheney P, Lazdunski M, Romey G, Barhanin J. Properties of KvLQT1 mutations in Romano-Ward and Jervell and Lange-Nielsen inherited cardiac arrhythmias. EMBO J. 1997:16:5472-5479.

26. Splawski I, Shen J, Timothy K, Vincent G, Lehmann M, Keating M. Genomic structure of Three Long QT Syndrome Genes: KVLQT1, HERG and KCNE1. Genomics. 1998;51:86-97.

27. Schulze-Bahr E, Haverkamp W, Wedekind H, Rubie C, Hördt M, Borggreve M, Assmann G, Breithardt $\mathrm{G}$. Funke H. Autosomal recessive long-QT syndrome (Jervell Lange-Nielsen syndrome) is genetically heterogeneous. Hum Genet. 1997;100:573-576.

28. Donger C, Denjoy I, Berthet M, Neyroud N, Cruaud C, Bennaceur M, Chivoret G, Schwartz K, Coumel P. Guicheney P. KVLQT1 C-teminal missense mutation cauases a forme frust long QT-syndrome. Circulation. 1997;96:2778-2781.

29. Li H, Chen Q, Moss A J, Robinson J, Goytia V, Perry J C, Vincent M, Priori SG, Lehmann MH, Denfield SW, Duff D, Kaine S, Shimizu W, Schwartz PJ, Wang Q, Towbin JA. New Mutations in the KVLQT1 Potassium Channel That Cause Long-QT Syndrome. Circulation. 1998:97:1264-1269.

30. Saarinen K, Swan H, Kainulainen K, Toivonen L, Viitasalo M, Kontula K. Molecular genetics of the Long QT Syndrome: Two Novel Mutations of the KVLQT1 Gene and Phenotype Expression of the Mutant Gene in a Large Kindred. Hum Mut. 1998; 11:158-165. 
31. Tanaka T, Nagai R, Tomoike H, Takata S, Yano K, Yabuta K, Haneda N, Nakano O, Shibata A, Sawayama T, Kasai H, Yazaki A, Nakamura Y. Four novel KVLQT1 and four novel HERG mutations in familial long-QT syndrome. Circulation. 1997;95:565-567.

32. Dausse E, Berthet M, Denjoy I, Andre-Fouet X, Cruaud C, Bennaceur M, Fauré S, Coumel P, Schwartz $K$, Guicheney P. A mutation in HERG associated with notched $T$ waves in long QT syndrome. J Mol Cell Cardiol. 1996;28:1609-1615.

33. Sanguinetti $M$, Curran $M$, Spector P, Keating $M$. Spectrum of HERG $K^{\cdot}$-channel dysfunction in an inherited cardiac arrhythmia. Proc Natl Acad Sci. 1996;93:2208-2212.

34. Smith PL, Baukrowitz T, Yellen C. The inward rectification mechanism of the HERG cardiac potassium channel. Nature. 1996;379:833-835.

35. Li X, XU J, Li M. The human del 1261 mutation of the HERG potassium channel results in a truncated protein that contains a subunit interaction domain and decreases the channel expression. J Biol Chem. 1997;272:705-708.

36. Itoh T, Tanaka T, Nagai R, Kamiya T, Sawayama T, Nakayama T, Tomoike H, Sakurada H, Yazaki Y, Nakamura Y. Genomic organisation and mutational analysis of HERG, a gene responsible for familial long QT syndrome. Hum Genet. 1998;102:435-439.

37. Benson WD, MacRae C A, Vesely MR, Walsh EP, Seidman JD, Seidman CE, Satler C. Missense mutations in the pore region of HERG causes familial Long QT Syndrome. Circulation. 1996;93:1791-1795.

38. Satler CA, Vesely M, Duggal P, Ginsburg GS, Beggs AH. Multiple different missense mutations in the pore region of HERG in patients with long QT syndrome. Hum Genet. 1998;102:265-272.

39. Akimoto K, Furutani M, Imamura S, Furutani Y, Kasanuki H, Takao A, Momma K, Matsuoka R. Novel Missense Mutation (G601S) of HERG in a Japanese Long QT Syndrome Family. Hum Mutat Suppl. 1997;1:184-186.

40. Satler CA, Walsh EP, Vesely MR, Plummer MH, Ginsburg GS, Jacob HJ. Novel missense mutation in the cyclic nucleotide-binding domain of HERG causes long QT syndrome. Am J of Med Genet. 1996; 65:27-35. 



\section{GENETIC ANALYSIS OF LOTS RELATED GENES}

DHPLC Analysis of Potassium lon Channel Genes in Congenital Long QT Syndrome

R.J.E. Jongbloed, C.M. Marcelis, C. Velter, P.A.F.M. Doevendans, J.P.M. Geraedts and H.J.M. Smeets.

Corrected edition based on: Human Mutation 20:382-391 (2002); Errata (2003) 


\begin{abstract}
Congenital Long QT Syndrome (LQTS) is electrocardiographically characterized by a prolonged QT interval and polymorphic ventricular arrhythmias (torsade de pointes). As a result of these arrhythmias patients suffer from recurrent syncopes, seizures or sudden death as the most dramatic event. Mutations in five genes, encoding cardiac ion channels, have been identified in LQTS. Two potassium channel genes (KCNQ1 and $\mathrm{KCNH} 2$ ) are frequently involved in LQTS. Potassium channel defects account for approximately $50-60 \%$ of LQTS. As patients benefit from preventive medication, early detection of a genetic defect is desired to identify the family members at risk. Speed and sensitivity of mutation detection was improved by applying the denaturing high performance liquid chromatography (DHPLC) technique for analysis of the entire KCNQ1 and KCNH2 genes and the protein encoding part of the KCNE1 and KCNE2 genes. By using this methodology, seven missense mutations in the KCNQ1 gene and nine mutations (four missense, two nonsense, one insertion and two deletions) in the $\mathrm{KCNH} 2$ gene have been identified in a total number of 32 index patients diagnosed with LQTS syndrome. We conclude that this method is suitable for rapid identification of LQT gene defects due to the combination of automation, high throughput, sensitivity and short time of analysis.
\end{abstract}

Databases: KCNQ1 - OMIM: 192500; GDB: 741244; Genbank: AFoo0571

KCNH2 - OMIM: 152427; GDB: 138126; Genbank: U04270

\title{
Introduction
}

Congenital Long-QT Syndrome (LQTS) is an inherited cardiac disorder caused by an abnormal cardiac repolarization time. A prolonged QT-interval on standard 12 lead ECG, T-wave abnormalities, and occasionally polymorphic ventricular arrhythmias known as Torsade de Pointes (TdP) characterize the disease [1]. These arrhythmias can result in recurrent syncope or sudden death as the most dramatic event [2-4]. Two clinical forms of LQTS exist; the Romano Ward syndrome (RWS) and the Jervell and Lange-Nielsen Syndrome (JLNS; MIM\# 220400). The segregation pattern of the cardiac symptoms is autosomal dominant for both the Romano Ward syndrome and the Jervell and Lange-Nielsen Syndrome (JLNS) while the bilateral sensorineural deafness is unique for JLNS and is inherited as an autosomal recessive trait $[5,6]$. Six chromosomal loci have been shown to harbor genes causing LQTS (LQT1-6), two of which are involved in JLNS (JLNS1-2) [7, 8]. Until now many mutations have been identified in five of these genes, encoding ion channels proteins [9], leaving only one locus (LQT4; MIM\# $600919)$ unresolved at this point [10]. 
Two genes KCNQ1 (LQT1; MIM\# 192500) and KCNH2 (LQT2; MIM\# 152427) encode the alpha-subunits of cardiac potassium ion channels [11, 12] regulating cardiac repolarization in the late phase 3 of the cardiac action potential. A cardiac sodium ion channel, important for initial depolarization of cardiac myocytes is encoded by the gene SCN5A (LQT3; MIM\# 603830) [13]. Mutations in the SCN5A gene also have been associated with Brugada syndrome (MIM\# 601144), Idiopathic Ventricular fibrillation (tachycardia) and Lenegre-Lev's disease or Progressive Cardiac Conduction Disease (PCCD; MIM\# 604559) [14-16], Sudden Infant Death Syndrome (SIDS; MIM\# 272120) [17] and sudden unexplained nocturnal death syndrome (SUNDS) [18]. Two minor genes KCNE1 (MinK; MIM\# 176261) and KCNE2 (MiRP1; MIM\# 603796) encode potassium channel regulatory proteins or ion channel B-subunits. Both are located on chromosome 21 and associated with LQTS and LQT6. Co-assembly of the auxiliary protein MinK and MiRP1 with ion channel gene products of KCNQ1 and KCNH2, form functional ion channel currents IK, and IK, respectively $[7,19]$. The vast majority of mutations associated with LQTS, have been identified in KCNQ1 and $\mathrm{KCNH}_{2}$ [9]. Mutations are registered in the Long QT database (address: www.ssi.dk/en/forskning/lqtsdb/lqtsdb.htm).

Mutation detection has mainly been performed by Single Strand Conformation Polymorphism Analysis (SSCP) which has a maximum detection sensitivity of $80 \%$ [20]. To improve the speed and sensitivity of mutation analysis, which is important to detect treatable carriers of potentially lethal disorders like LQTS, we developed a Denaturing High Performance Liquid Chromatography (DHPLC) based protocol to screen the KCNQ1 and KCNH2 (HERG) genes. Although KCNE1 and KCNE2 are not frequently involved in LQTS, the protein ejicoding part of the two minor genes KCNE1 and KCNE2 was additionally screened to exclude their involvement. DHPLC is an easy and non-destructive detection method with a nearly $100 \%$ detection rate in blind trials [21].

The method is based on different melting temperatures between hetero- and homoduplexes of mutated and wild type DNA fragments, generated by Polymerase Chain Reaction (PCR). Unpurified fragments are injected and attached to the solid phase of the DHPLC column. At a temperature just below melting temperature, fragments are eluted from the column by using a linear acetonitrile gradient. The reduced affinity of melting DNA for the solid phase ensures that the less stable heteroduplexes are eluted prior to homoduplexes [22]. Until now several investigators have reported the implementation of DHPLC for diagnostic screening purposes. Genes, like BRCA1 and BRCA2, Notch 3 with a high GC-content, MepC2, and TSC1 and the entire mtDNA have been analyzed successfully [23-27]. The DHPLC system allows automatic analysis of DNA fragments within minutes. For a detailed review we refer to Xiao and Oefner [28].

Here we report the optimized protocol for screening the potassium channel LQTS genes by DHPLC analysis and mutations identified in the KCNO1 and the KCNH2 gene, 
in individuals with clinical symptoms of Long QT syndrome. Additionally we report a number of single nucleotide polymorphisms (SNPS), additionally identified in exon and intron sequences of KCNQ1, KCNH2 and KCNE2 genes identified in the 32 families analyzed by this method.

\section{Materials \& methods}

\section{Patients}

Thirty-two blood samples of index patients from Dutch (\# 30) and Belgian (\# 2) families, diagnosed with congenital Long-QT syndrome, were sent to our genetic center. In one family linkage was found with the LQT1 (KCNQ1) locus, but no mutation was detected by SSCP analysis. DNA samples from 13 individuals, with a previously identified genetic defect in either the KCNQ1 ( 8 mutations) or $\mathrm{KCNH}_{2}$ (5 mutations) gene, were used as positive controls to verify the efficacy of the DHPLC mutation detection system. These mutations were identified in our laboratory by using SSCP and sequencing analysis and have been described previously [29, 30].

\section{Amplification of the KCNQ1 gene}

DNA fragments were generated by using combinations of primers as described previously by several investigators [12, 31, 32]. All exons, numbered according to Splawski et al.,[33] and encoding four isoforms of the KCNQ1 gene, were amplified. Primer sequences and PCR conditions are presented in Table 1. Exon 1 of the KCNQ1 gene was amplified in two overlapping fragments (exon 1.1 and exon 1.2) by using a TouchDown PCR technique (TD-PCR) [34]. Genomic DNA was diluted to $50 \mathrm{ng} / \mu \mathrm{l}$ and amplified in a total volume of $50 \mu \mathrm{l}$. For PCR reactions a Perkin Elmer 9700 PCR thermal cycler (Applied Biosystems, Foster City, CA), 10x reaction buffer and $50 \mathrm{mM} \mathrm{MgCl}$ solutions, provided by Life technologies (Breda, The Netherlands), $100 \mathrm{ng}$ forward primer and reversed primer, $0.2 \mu \mathrm{M}$ dNTP (Amersham Pharmacia Biotech, Uppsala, Sweden), 1 Unit Taq DNA polymerase (Qiagen, Leusden, The Netherlands) were used.

\section{Amplification of the $\mathrm{KCNH} 2$ gene}

All exons, encoding the entire sequence of the $\mathrm{KCNH} 2$ (HERG) gene, were PCR amplified. Primer combinations (Table 2) were selected from previously described reports $[11,29,31,32,35]$. PCR reactions were performed as described for the KCNQ1 gene, except that 40 cycles of amplification were used for exon 5 . To amplify exon 1 , a final concentration of $1 \mathrm{M}$ betaine was supplemented to the reaction mix in a final volume of $25 \mu \mathrm{l}$.

\section{Amplification of the KCNE1 and KCNE2 genes}

Mutation detection was performed for the protein encoding part (exon 3) of the KCNE1 gene and the KCNE2 gene. PCR conditions and primer sequences, selected from previous reports, are presented in Table $3[19,31]$. 


\section{DHPLC analysis}

Prior to DHPLC analysis, a re-annealing step was introduced after DNA amplification. PCR products were denatured at $95^{\circ} \mathrm{C}$ for 5 minutes and cooled down to $65^{\circ} \mathrm{C}$ $\left(1^{\circ} \mathrm{C} / \mathrm{min}\right)$. Amplified fragments of $\mathrm{KCNH} 2$ exon 1 were purified by using the Qiaquick PCR purification kit protocol (Qiagen, Valencia, CA) to avoid betaine loading on the column.

DHPLC analysis was performed on an automated DNA fragment analysis system (Wave $^{\text {tw }}$, Hitachi model D-7000 version 3.0, Transgenomics, San Jose, CA). The PCR product $(5-10 \mu \mathrm{l})$ was injected on a preheated column packed with alkylated nonporous polystyrene-divinylbenzene particles (DNASep, Transgenomics). DNA was eluted from the stationary phase by using a linear acetonitril gradient formed by mixing buffer $A$ $(0,1 \mathrm{M}$ triethylamine acetate TEAA, pH7.0) and buffer $\mathrm{B}(0,1 \mathrm{M}$ TEAA, pH7.0 with $25 \%$ $\mathrm{v} / \mathrm{v}$ acetonitrile; Biosolve LTD, HPLC grade). The increase of buffer B was $2 \%$ per minute at a flow rate of $0,9 \mathrm{ml} / \mathrm{min}$. Buffers were prepared with milliQ water $(18,2 \mathrm{M \Omega cm})$.

Optimization was initiated by deducing the optimal \% B (based on the retention time at $50^{\circ} \mathrm{C}$ ) for each amplified fragment by using a nondenaturing universal gradient (buffer B gradient: 40-72\%; 16 min running time). Subsequently the appropriate gradient $\% \mathrm{~B}$ and column temperatures, ranging from $56^{\circ} \mathrm{C}$ to $70^{\circ} \mathrm{C}\left(2^{\circ} \mathrm{C}\right.$ interval), were used to construct the DNA melting curve. From these empirically determined data the oven temperature for optimal mutation detection was obtained and compared with 1) the theoretical data calculated by the melting algorithm freely available at the Stanford DHPLC website http://insertion.stanford.edu/melt.html and 2) the melting program provided by WAVEmaker 4.0 utility control software (Transgenomics, Inc). By combining these results, temperatures for successful heteroduplex separation were achieved. Some fragments showed distinct melting domains. In those cases additional analyzing temperatures were used.

The analytic conditions were optimized for 6.7 minutes total running time. The initial and final concentrations of buffer B ( $2 \%$ per minute for 5 minutes) were adjusted to obtain retention times between 3 and 4 minutes. After each run the column was cleaned with $100 \%$ buffer $B$ and equilibrated $(1.5 \mathrm{~min})$ at the starting conditions. If available, positive controls were run at temperatures preferably 1-2 degrees above and below the empirically calculated running temperature. The elution profiles were independently judged by two technicians. Also a reduced peak signal or peak broadening was considered to be suspicious if equal amounts of DNA samples had been loaded to the stationary phase. The optimized elution profiles and melting temperatures of the entire coding sequences of KCNQ1 and $\mathrm{KCNH} 2$ are presented in Table 1 and 2 respectively. Analyzing conditions for KCNE1 and KCNE2 are presented in Table 3. 
Table 1. Conditions for amplification and DHPLC analysis of KCNQ1 (KvLQT1)

\begin{tabular}{|c|c|c|c|c|c|c|c|c|}
\hline $\begin{array}{l}\text { KCNQ1 } \\
\text { exon }\end{array}$ & Region & {$\left[\mathrm{MgCl}_{2}\right]$} & $\begin{array}{l}\operatorname{Tan}{ }^{\circ} \mathrm{C} \\
P C R\end{array}$ & $\begin{array}{l}\text { Product } \\
\text { basepairs }\end{array}$ & Primer forward $5^{\prime}-3^{\prime}$ & Primer reversed $5^{\circ}-3^{\prime}$ & $\begin{array}{l}\text { Gradient } \\
\% \text { B; Temp }{ }^{\circ} \mathrm{C}\end{array}$ & $\begin{array}{l}\text { Gradient } \\
\% \text { B;Temp }{ }^{\circ} \mathrm{C}\end{array}$ \\
\hline 1.1 & & $1.0 \mathrm{mM}(*)$ & TD 70-60 & 334 & ctcgccttcgctgcagctc & gcgcgggtctaggcttacc & $55 \%-65 \% ; 66$ & $55 \%-65 \% ; 71$ \\
\hline 1.2 & S1 & $1.0 \mathrm{mM}(* *)$ & TD $70-60$ & 244 & cgccgcggccccagttgc & cagagctcccccacaccag & $52 \%-62 \% ; 66$ & \\
\hline $1 b$ & Isoform2 & $1.5 \mathrm{mM}$ & 56 & 238 & ttactcagcccacatcacg & cacccataactgaccacaattc & $52 \%-62 \% ; 59$ & $52 \%-62 \% ; 64$ \\
\hline $1 c$ & Isoform 3 & $1.5 \mathrm{mM}$ & 56 & 228 & ccttccatgcatgctttca & gacacgtgggcagctcaagg & $52 \%-62 \% ; 56$ & $52 \%-62 \% ; 64$ \\
\hline 2 & $S 152$ & $1.0 \mathrm{mM}$ & 56 & 210 & gtgcatctgtgggatgggca & agggagatgccagcttccaa & $49 \%-59 \% ; 64$ & \\
\hline $2 a$ & Isoform4 & $1.5 \mathrm{mM}$ & 56 & 397 & ccgagcaccattcaacataagtc & ctgaaatgagtgcctcgag & $57 \%-67 \% ; 61$ & $57 \%-67 \% ; 64$ \\
\hline 3 & $52 S_{3}$ & $1.5 \mathrm{mM}$ & 56 & 242 & cagggtctgaagccactcaag & cttcctggtctggaaacctggg & $52 \%-62 \% ; 66$ & \\
\hline 4 & S3S4 & $1.0 \mathrm{mM}$ & 60 & 171 & ctcttcctggggccgtggc & tgcgggggagcttgtggcacag & $48 \%-58 \% ; 65$ & \\
\hline 5 & $\$ 4$ & $1.5 \mathrm{mM}\left({ }^{*}\right)$ & TD $70-60$ & 123 & gggcatccgcttcctgcaga & ctgggccccgcacccctaacce & $45 \%-55 \% ; 64$ & $45 \%-55 \% ; 65$ \\
\hline 6 & S5-pore & $1.0 \mathrm{mM}$ & 62 & 236 & tcctggagcccgacactgtgtgt & tgtcctgcccactcctcagcct & $56 \%-66 \% ; 61$ & \\
\hline 7 & pore-56 & $1.0 \mathrm{mM}$ & 62 & 195 & tggctgaccactgtecctct & ccccaggaccccagctgtccaa & $50 \%-60 \% ; 62$ & \\
\hline 8 & 56 & $1.0 \mathrm{mM}$ & 62 & 191 & gctggcagtggcctgtgtgga & aacagtgaccaaaatgacagtgac & $50 \%-60 \% ; 62$ & \\
\hline 9 & & $\mathrm{mM}\left({ }^{*}\right)$ & TD 70-65 & 267 & gggaacagggagggggagct & ggcctccccacctgctagca & $53 \%-63 \% ; 63$ & \\
\hline 10 & & $1.0 \mathrm{mM}$ & 56 & 295 & agggcctggcagacgatgtc & cacagcccaagggagaaa & $54 \%-64 \% ; 60$ & $54 \%-64 \% ; 63$ \\
\hline 11 & & $1.0 \mathrm{mM}$ & 60 & 248 & cctggccctgggagctcaca & cctccagcccagcccttcac & $52 \%-62 \% ; 62$ & \\
\hline 12 & & $1.5 \mathrm{mM}$ & 64 & 233 & gcaggggcagtgaggggatg & ggcaggagagaacccaggag & $52 \%-62 \% ; 62$ & \\
\hline 13 long & & $1.0 \mathrm{mM}$ & 62 & 236 & tggggcacagggaggagatg & caccctccecgctgecgttt & $54 \%-64 \% ; 63$ & $54 \%-64 \% ; 66$ \\
\hline 13short & & $1.5 \mathrm{mM}$ & 60 & 170 & tggggcacagggaggagatg & ctcageccetccetcctccg & $49 \%-59 \% ; 64$ & \\
\hline 14 & & $1.5 \mathrm{mM}$ & 64 & 161 & gcagtgccagggccaggtgt & agggcagaggtgcgggagag & $47 \%-57 \% ; 63$ & \\
\hline 15 & & $0.5 \mathrm{mM}$ & 64 & 217 & cccggcccaccccagcactt & gggaggcctgcaggagcttc & $50 \%-60 \% ; 65$ & \\
\hline 16 & & $1.0 \mathrm{mM}$ & 60 & 390 & gttggcaccttcccttctctg & ctcttggcctcccctctcact & $55 \%-65 \% ; 66$ & \\
\hline
\end{tabular}

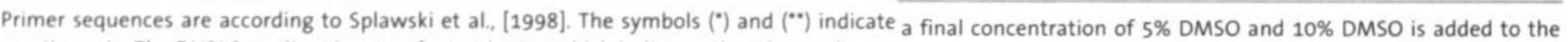

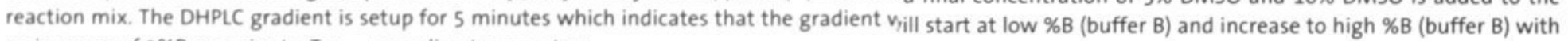
an increase of $2 \% \mathrm{~B}$ per minute. Tan $=$ annealing temperature 
Table 2. Conditions for amplification and DHPLC analysis of KCNH2 (HERG)

\begin{tabular}{|c|c|c|c|c|c|c|c|c|}
\hline $\begin{array}{l}\text { HERG-A } \\
\text { Exon }\end{array}$ & Region & {$\left[\mathrm{MgCl}_{2}\right]$} & $\begin{array}{l}\operatorname{Tan}^{\circ} \mathrm{C} \\
\text { PCR }\end{array}$ & $\begin{array}{l}\text { Product } \\
\text { basepairs }\end{array}$ & Primer forward $5^{\prime} \cdot 3^{\prime}$ & Primer reversed $5^{\prime}-3^{\prime}$ & $\begin{array}{l}\text { Gradient } \\
\% \text { B ; Temp }{ }^{\circ} \mathrm{C}\end{array}$ & $\begin{array}{l}\text { Gradient } \\
\% \text { B ; Temp }{ }^{\circ} \mathrm{C}\end{array}$ \\
\hline 1 & & $2.0 \mathrm{mM}(*)$ & TD 62.50 & 144 & ccgcccatgggctcagg (1) & catccacactcggaagaagt (2) & $51 \%-61 \% ; 66$ & $44 \%-54 \% ; 70$ \\
\hline 2 & PAS & $0.5 \mathrm{mM}$ & TD 70.65 & 305 & cgcactctcctcaccgcccc (1) & ccctcttgaccecgecctg (1) & $59 \%-69 \% ; 65$ & $53 \%-63 \% ; 68$ \\
\hline 3 & & $1.0 \mathrm{mM}$ & TD 68.58 & 215 & tgcccactgagtgggtgc (2) & tgaccttggacagctcacag (2) & $57 \%-67 \% ; 63$ & $57 \%-67 \% ; 64$ \\
\hline 4.1 & & $1.0 \mathrm{mM}(* *)$ & 64.2 & 267 & acgaccacgtgectctcctctc (2) & gggacccaccagcgcacgccg (2) & $57 \%-67 \% ; 68$ & $56 \%-66 \% ; 69$ \\
\hline 4.2 & & $1.0 \mathrm{mM}(* *)$ & 67.7 & 319 & ccctggacgaagtgacagccatgg (2) & ggctggggcggaacgggtcc (2) & $56 \%-66 \% ; 63$ & $56 \%-66 \% ; 71$ \\
\hline 5 & & $0.5 \mathrm{mM}$ & TD 65.55 & 279 & gcctcaccacgctgcctct (2) & cctccaaggtgagaggaga (2) & $58 \%-68 \% ; 63$ & $57 \%-67 \% ; 66$ \\
\hline 6 & $\$ 1.53$ & $1.5 \mathrm{mM}(*)$ & 64 & 505 & gtcccatggcctgcctcacc (3) & ctacaccacctgectecttgctgac (1) & $61 \%-71 \% ; 63$ & $60 \%-70 \% ; 64$ \\
\hline \multirow[t]{2}{*}{7} & $54-\$ 6$ & $1.0 \mathrm{mM}$ & 64 & 400 & tgccccatcaacggaatgt (1) & gcccgcccctgggcacactca (1) & $62 \%-72 \% ; 63$ & $62 \%-72 \% ; 65$ \\
\hline & & & & & & & $62 \%-72 \% ; 64$ & $62 \%-72 \% ; 66$ \\
\hline 8 & S6 & $1.0 \mathrm{mM}$ & 62 & 327 & ctgacctggtgcggggectg (3) & cccagcctgccacccact (3) & $59 \%-69 \% ; 65$ & $59 \%-69 \% ; 66$ \\
\hline 9 & NBD & $1.0 \mathrm{mM}$ & 62 & 331 & ccaagggagggtgtgctgag (2) & ggcatttccagtccagtgc (2) & $58 \%-68 \% ; 64$ & $58 \%-68 \% ; 65$ \\
\hline 10 & NBD & $0.5 \mathrm{mM}$ & 62 & 291 & ccceggggctgagctccctgtc (3) & tccagctcagggcagccaa (2) & $56 \%-66 \% ; 63$ & $56 \%-66 \% ; 64$ \\
\hline 11 & & $1.0 \mathrm{mM}$ & TD $70-65$ & 189 & aagggecctgatactgatttt (1) & ttccagctcccagcctca (2) & $54 \%-64 \% ; 62$ & $55 \%-65 \% ; 64$ \\
\hline 12.1 & & $0.5 \mathrm{mM}$ & 49 & 271 & tgaggcccattctctgtttcc (4) & cttctcgcagtcctccatca (2) & $57 \%-67 \% ; 63$ & $55 \%-65 \% ; 66$ \\
\hline 12.2 & & $0.5 \mathrm{mM}$ & 58 & 209 & tgagagcagtgaggatga (2) & tagacgcaccaccgctgcc (2) & $55 \%-65 \% ; 65$ & $52 \%-62 \% ; 68$ \\
\hline 13 & & $0.5 \mathrm{mM}$ & TD 65.55 & 274 & ctgacccagctctgctctctg (1) & caccaggacctggaccagact (1) & $57 \%-67 \% ; 65$ & $55 \%-65 \% ; 66$ \\
\hline 14 & & $0.5 \mathrm{mM}$ & 62 & 287 & atcccggtggaggctgtca (2) & gaacaagcgggccacggtac (2) & $58 \%-68 \% ; 64$ & $55 \%-65 \% ; 66$ \\
\hline 15 & & $0.5 \mathrm{mM}$ & 62 & 251 & tgcccatgctctgtgtgtattg (1) & acgtgtccacactgggcag (2) & $57 \%-67 \% ; 62$ & $54 \%-64 \% ; 66$ \\
\hline \multicolumn{9}{|l|}{ HERG-B } \\
\hline $1 b$ & & $0.5 \mathrm{mM}$ & TD $70-60$ & 200 & ggtgcaggtgaggcagtgg (1) & cggccccagaaagaagaggaa (1) & $54 \%-64 \% ; 64$ & $52 \%-62 \% ; 68$ \\
\hline \multicolumn{9}{|l|}{$H_{E R G}$} \\
\hline \multirow[t]{2}{*}{9} & USO & $1.0 \mathrm{mM}$ & 62 & 532 & agcactgcaaacccttccgag & tagtgaaaccaaatgccgagc & $62 \%-72 \% ; 60$ & $58 \%-68 \% ; 66$ \\
\hline & & & & & & & $62 \%-72 \% ; 64$ & \\
\hline
\end{tabular}

Primer sequences are according to Splawski et al.,1998 (1); Itoh et al., 1998 (2); Jongbloed et al., 1999 (3); Janssen Pharmaceutics (4) (personal communication). The symbols $\left({ }^{*}\right)$ and $\left({ }^{*}\right)$ indicate a final concentration of $5 \%$ DMSO and $10 \%$ DMSO is added to the reaction mix. The DHPLC gradient is setup for 5 minutes which indicates that the gradient will start at low \% B (buffer B) and increase to high \% B (buffer B) with an increase of $2 \% \mathrm{~B}$ per minute. For the amplification of $\mathrm{KCNH} 2$ exon 5 a total number of 40 cycles were used. Tan $=$ annealing temperature. 
noncoding region intron 13 (IVS13+36 g>a). The disease causing mutation is situated in the intracellular C-terminal protein part of the KCNQ1 $\alpha$-subunit. It creates an additional 'unique' Taql restriction site. This was used to identify carriers of the gene defect in this family. Subsequently we developed a more 5' upstream primer (ex13short) to avoid the intronic polymorphism (Figure 1D). All mutations mentioned in this report have been identified in the Dutch families except for the mutations, Ala341Val (1022 C>T) and Gly316Arg (946 G>C), which originated from Belgium.

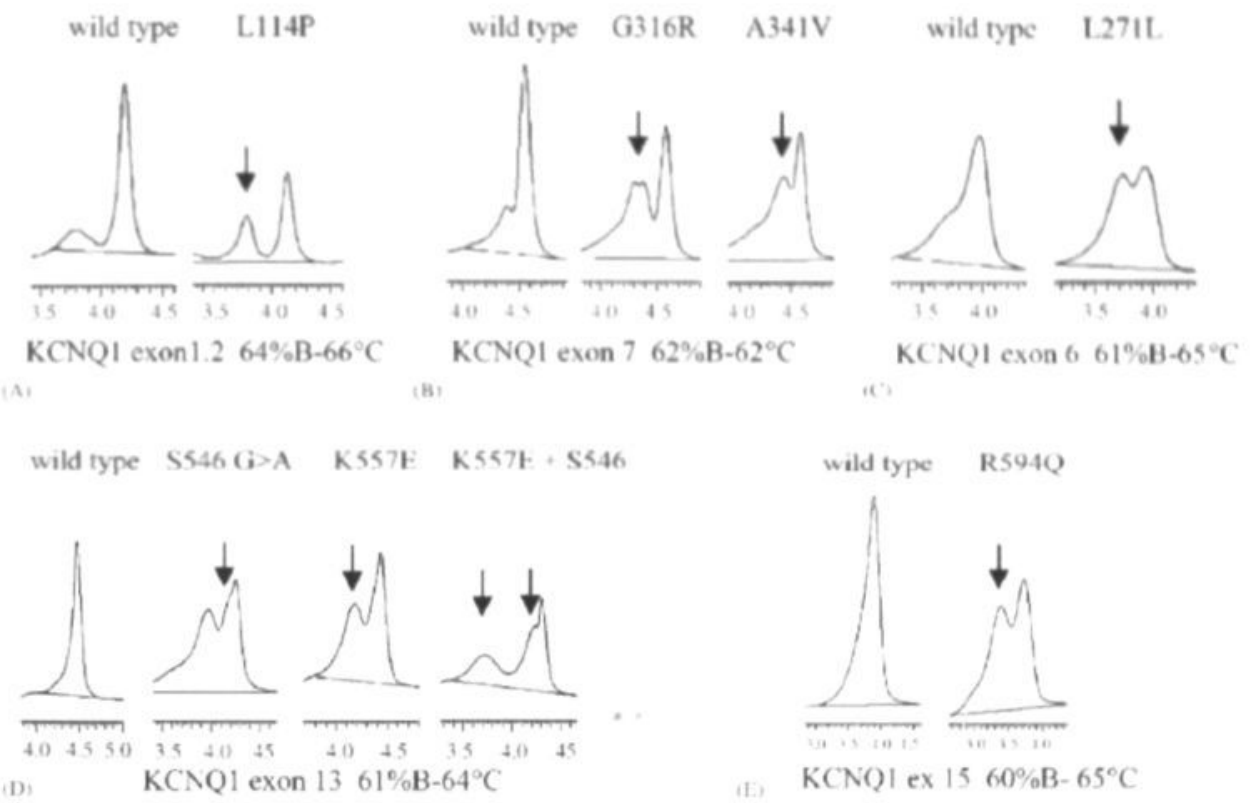

Figure 1. DHPLC elution profiles of five out of seven KCNO1 missense mutations identified in families with LQTS. The first elution profile in each block refers to the wild type of the exon analyzed. The DHPLC condition (Gene, exon, \% B and temperature) is indicated below the elution profiles. At the X-axis of the elution profiles, a time scale (minutes) indicates the elution time of the DNA fragments. The Y-axis (not shown) the absorption at $260 \mathrm{~nm}$ wavelenght indicates the amount of DNA. Note the decrease in absorption if additional peaks are present indicating a DNA variant. For this reason the subdivision of the $\mathrm{Y}$-axis was kept constant for each block (A-E). An arrow indicates the DNA-heteroduplex fragments that are eluted prior to the DNA-homoduplexes. D: The elution profiles in exon 13(short) of the nucleotide variant $\mathrm{S} 546 \mathrm{~S}$ and the missense mutation $\mathrm{K} 557 \mathrm{E}$ and a combination of both $\mathrm{S} 546 \mathrm{~S}+\mathrm{K} 557 \mathrm{E}$.

\section{Analysis of $\mathrm{KCNH2}$}

All positive controls were also readily detected by DHPLC analysis in the $\mathrm{KCNH} 2$ gene. Next, we identified 16 elution profiles that were different from wild type DNA samples (Figure 2). Sequencing analysis revealed eight novel mutations, one previously reported missense mutation and seven single nucleotide variants (SNPS) within the $\mathrm{KCNH} 2$ gene (Tables 4 and 5 ). 
Table 3. Conditions for Amplification and DHPLC analysis of KCNE1 and KCNE2

\begin{tabular}{|c|c|c|c|c|c|c|c|c|}
\hline Gene & $\begin{array}{l}\text { Region } \\
\text { exon }\end{array}$ & {$\left[\mathrm{MgCl}_{2}\right]$} & $\begin{array}{l}\text { Tan } \\
{ }^{\circ} \mathrm{C} \\
\text { PCR }\end{array}$ & $\begin{array}{l}\text { Product } \\
\text { bp }\end{array}$ & $\begin{array}{l}\text { Primer } \\
\text { forward } 5^{\prime}-3^{\prime}\end{array}$ & $\begin{array}{l}\text { Primer } \\
\text { reversed } 5^{\prime}-3^{\prime}\end{array}$ & $\begin{array}{l}\text { Gradient } \\
\% \text { B;Temp } \\
{ }^{\circ} \mathrm{C}\end{array}$ & $\begin{array}{l}\text { Gradient } \\
\% \text { B;Temp } \\
{ }^{\circ} \mathrm{C}\end{array}$ \\
\hline KCNE1 & 3 & $1.5 \mathrm{mM}$ & 62 & 446 & $\begin{array}{l}\text { cct-gca-gca-gtg- } \\
\text { gaa-cct-taa-tg }\end{array}$ & $\begin{array}{l}\text { agg-tgt-cca-gtt- } \\
\text { tag-cca-gtg }\end{array}$ & $\begin{array}{l}57 \%-67 \% \text {; } \\
64\end{array}$ & \\
\hline KCNE2 & 3 & $1.0 \mathrm{mM}$ & 53.2 & 470 & $\begin{array}{l}\text { ccg-ttt-tcc-taa- } \\
\text { cct-tgt-tcg }\end{array}$ & $\begin{array}{l}\text { tgt-ctg-gac-gtc- } \\
\text { aga-tgt-tag }\end{array}$ & $\begin{array}{l}47 \%-57 \% ; \\
66\end{array}$ & $\begin{array}{l}47 \%-57 \% \\
70\end{array}$ \\
\hline
\end{tabular}

Primer sequences are according to Splawski et al., 1998 (KCNE1; Mink) and Abbot et al., 1999 (KCNE2; MiRP1). Tan = annealing temperature.

\section{Sequencing analysis}

PCR fragments were purified with Qiaquick PCR purification kit (Qiagen) and sequenced using the Big-Dye termination cycle sequencing kit (Applied Biosystems). Sequencing reactions were purified using ethanol precipitation and applied on a automatic sequencer (ABI3100; Applied Biosystems). Results

\section{Analysis of KCNQ1}

Without exception, all positive controls were readily identified in the KCNQ1 gene as abnormal DHPLC profiles. Next, within the group of 32 individuals we observed 20 different elution profiles by DHPLC analysis (Figure 1). After sequencing analysis we identified seven disease causing missense mutations and fourteen single nucleotide polymorphisms (SNPS) within the coding and noncoding regions of the KCNQ1 gene The disease causing missense mutations are presented in order of amino acid numbering in Table 4 and the single nucleotide polymorphisms in Table 5. Some of the DHPLC elution profiles demonstrating profiles of wild type and missense mutations are presented in Figure 1 (A-F). Three of the missense mutations mentioned above were novel and had occurred in exon 1 (Leu114Pro; 341T>C), exon 7 (Gly316Arg; 946 G>C) and in exon 13 (Lys557Glu; $1669 \mathrm{G}>\mathrm{A}$ ). These mutated amino acids were highly conserved in several species, segregated with the disease in the family and were excluded in at least 100 control chromosomes from a group of healthy individuals, thereby strongly supporting a pathogenic role. The mutation Leu114Pro is located in the initial intracellular part of the $\mathrm{N}$-terminus of the KCNQ1 protein. The mutation Gly316Arg occurred in the pore-\$6 domain and is surrounded by several, previously reported, missense mutations identified in LQTS patients. The final novel mutation Lys557Glu resides in the C-terminal part of the potassium ion channel. A member of the family, previously linked to KCNQ1, showed an abnormal elution profile in exon 13 (ex13long) after re-analyzing by DHPLC that had not been detected as an aberrant conformer by SSCP analysis. Within this amplified product, using sequencing analysis, three nucleotide substitutions were identified. Besides the novel missense mutation Lys557Glu two additional polymorphisms were present in the same PCR fragment, the previously reported silent mutation Ser546Ser G>A [36] and a g to a transition in the 
Examples of elution profiles are presented in Figure 2 (A-E). Four mutations cause amino acid substitutions and five mutations result in a stop codon which causes a Cterminal truncated $\alpha$-subunit of the $\mathrm{KCNH}_{2}$ protein. Two novel missense mutations Leu87Pro (260 T>C) and Tyr99Ser (296 A>C) have been identified in exon 2 and are located within the PAS domain of $\mathrm{KCNH} 2$. DHPLC analysis of exon 6 indicated the presence of a nonsense mutation Tyr447stop (1341 A>C) and a novel missense mutation Asp501Asn (1501 G>A) in 2 unrelated patients. They are located in the S1 and $\mathrm{S} 3$ transmembrane spanning segments respectively (Fig. 2E). A nonsense mutation Glu698stop (2092 G>T) was identified in exon 8 which encodes the S6-II domain and creates a premature stop in the intracellular region S6-NBD (nucleotide binding domain) of $\mathrm{KCNH} 2$. In exon 10 the insertion of one nucleotide at position (2471insG; L824fs 828 ) and in exon 11 a deletion of one nucleotide at position 2616 codon 872 (2616delC; P872fs877) were identified. Finally a deletion of 5 nucleotides (578_582delCCGTG; Gly192fs328) in exon 4 was detected. The resulting frameshift predicts a truncated protein, which contains only the $\mathrm{N}$-terminal part of the protein and completely lacks the transmembrane part S1-S6 and C-terminal part.

\section{Table 4. Pathogenic LQTS mutations Identified by DHPLC analysis}

\begin{tabular}{|c|c|c|c|c|}
\hline Gene & Nucleotide change & Coding effect & Position & Exon \\
\hline KCNQ1 & 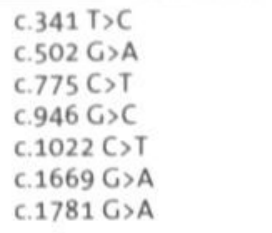 & $\begin{array}{l}\text { p.Leu114Pro* } \\
\text { p.Gly168Arg* } \\
\text { p.Arg259Cys } \\
\text { p.Gly316Arg } \\
\text { p.Ala341Val } \\
\text { p.Lys557Glu* } \\
\text { p.Arg594GIn }\end{array}$ & $\begin{array}{l}\text { N-terminal } \\
\text { S2 } \\
\text { S4-S5 } \\
\text { Pore } \\
\text { S6 } \\
\text { C-terminal } \\
\text { C-terminal }\end{array}$ & $\begin{array}{c}1 \\
3 \\
5 \\
7 \\
7 \\
13 \\
15\end{array}$ \\
\hline $\mathrm{KCNH} 2$ & $\begin{array}{l}\text { c. } 260 \mathrm{~T}>C \\
\text { c. } 296 \mathrm{~A}>\mathrm{C} \\
\text { C. } 578 \_582 \text { delCCGTG } \\
\text { C. } 1039 \mathrm{C}>\mathrm{T} \\
\text { C. } 1341 \mathrm{C}>\mathrm{A} \\
\text { C. } 1501 \mathrm{G}>\mathrm{A} \\
\text { C. } 2092 \mathrm{G}>\mathrm{T} \\
\text { c. } 2471 \text { ins } \\
\text { c. } 2616 \text { delC }\end{array}$ & $\begin{array}{l}\text { p.Leu87Pro } \\
\text { p.Tyr99Ser } \\
\text { p.Gly } 192 \mathrm{fs} / 328^{\circ} \\
\text { p.Pro3475er } \\
\text { p.Tyr } 447 \text { stop }^{\circ} \\
\text { p.Asp501Asn } \\
\text { p.Glu698stop } \\
\text { p.Leu } 824 \mathrm{fs} / 828^{\circ} \\
\text { p.Pro } 872 \mathrm{fs} / 877^{\circ}\end{array}$ & $\begin{array}{l}\text { PAS } \\
\text { PAS } \\
\text { N-terminal } \\
\text { N-terminal } \\
\text { S1-S2 } \\
\text { S3 } \\
\text { S6-NBD } \\
\text { NBD } \\
\text { C-terminal }\end{array}$ & $\begin{array}{c}2 \\
2 \\
4 \\
5 \\
6 \\
6 \\
8 \\
10 \\
11\end{array}$ \\
\hline
\end{tabular}

The nucleotide numbering starts from the ATG start codon. Genbank accession numbers; AF000571 (KCNQ1), U04270 (KCNH2). Novel mutations are indicated with an asterisk. The missense mutation Arg259Cys has been reported previously in a Japanese family with LQTS by Kubota et al. [37].

\section{Analysis of KCNE1}

DHPLC analysis of exon 3 showed complex elution profiles due to the occurrence of three SNPs. Almost all fragments had to be sequenced. Apart from the three polymophisms Ser28Ser G>A, Ser38Gly G>A and Asp85Asn G>A, sequencing analysis did not reveal any nucleotide substitutions in our group of patients. The allele frequency of SNPs identified in this cohort study are presented in Table 5. 


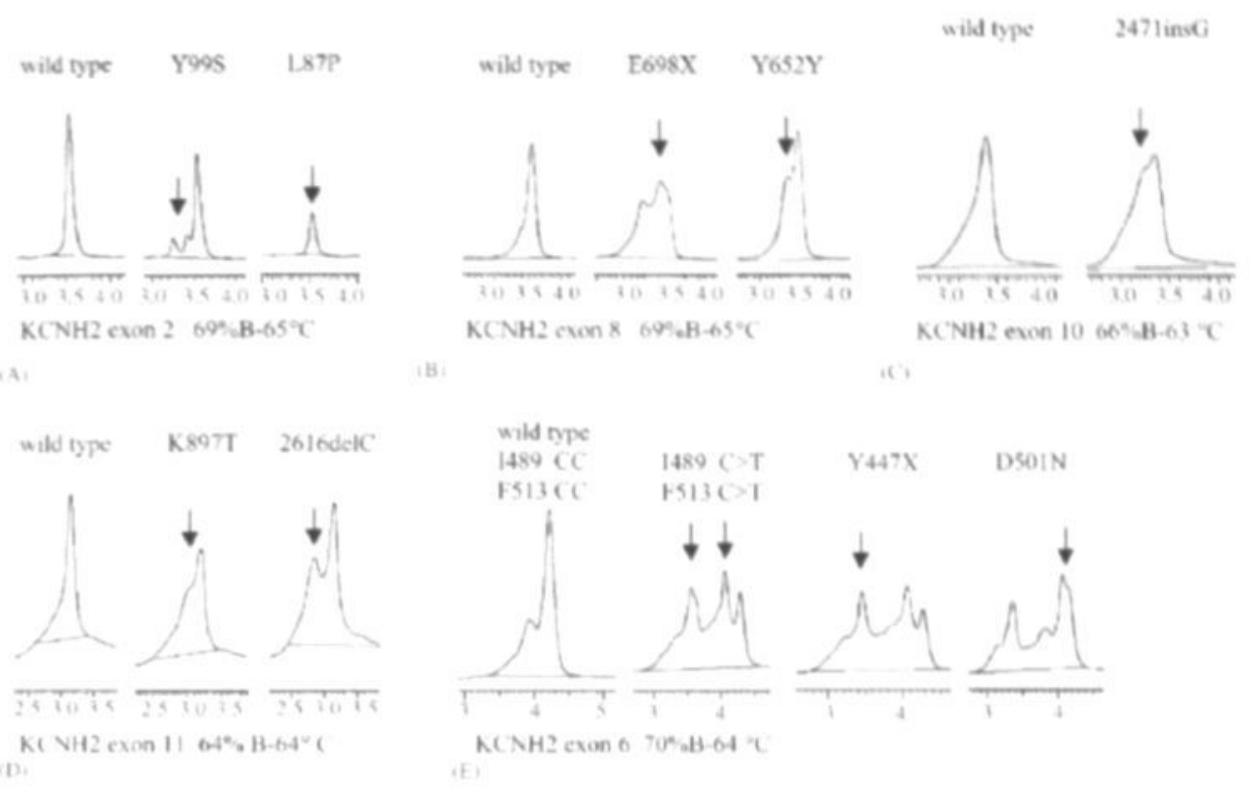

Figure 2. DHPLC elution profiles of seven out of nine pathogenic $\mathrm{KCNH} 2$ mutations identified in families with LQTS. For details we refer to the legends of Figure 1. An arrow indicates the DNA-heteroduplex fragments that are eluted prior to the DNA-homoduplexes. A: Note the dramatic decrease in absorption and the absence of an additional peak in exon 2 in the presence of the mutation L87P. D shows the elution profiles of the single amino acid polymorphism K897T and in combination with 2616delC. E shows the different elution profiles of $\mathrm{KCNH} 2$ exon 6 with two highly polymorphic variants ( 1489 and F513). These two variants were also present in one individual carrying the mutation $Y 420 X$ and one individual carrying the mutation D501N.

\section{Analysis of KCNE2}

By DHPLC analysis of exon 3 we identified two abnormal elution profiles. Sequencing analysis indicated an a to $\mathrm{g}$ transition which had occurred 28 basepairs upstream the initial ATG codon (ATG-28 a>g) and an A to G transition at position 22 (Thr8Ala) of the KCNE2 gene. The amino acid variant Thr8Ala ( $22 \mathrm{~A}>\mathrm{G})$ has been associated with an acquired form of LQT [38]. The Thr8Ala variant was identified twice in a group of thirty-two individuals. The 5'UTR polymorphism has been identified in 5 individuals. SNPs identified in this study are presented in Table 5.

\section{Discussion}

Congenital Long QT syndrome is characterized by abnormal ventricular repolarization and associated with cardiac arrhythmias and sudden death. Mutations in 5 genes have been identified as disease causing defect. However $87 \%$ of the mutations have been identified within two potassium channels KCNQ1 (LQT1) and KCNH2 (LQT2). Although 
the KCNE1 (LQT5) and KCNE2 (LQT6) genes are not frequently involved in LQTS ( $3 \%$ and $2 \%$ ) as such, their involvement should not be excluded as they co-assemble with the gene product of the LQT1 and LQT2 locus to form the KCNQ1/MinK and the KCNH2/MiRP1 complex [9].

Table 5. Single Nucleotide Polymorphisms (SNPs) Identified in the KCNQ1, KCNH2, KCNE1 and KCNE2 Genes

\begin{tabular}{|c|c|c|c|c|}
\hline Gene & Nucleotide change & Effect & Intron/exon & $\begin{array}{c}\text { Percentage of heterozygotes in } \\
\text { the patients group }\end{array}$ \\
\hline \multirow[t]{14}{*}{ KCNQ1 } & C.1_5 T>C & Kozak variant & 5' UTR & 0.10 \\
\hline & c. $3 \overline{8} 7+217 C>T$ & Unclassified & exon $2 a$ & 0.12 \\
\hline & c. $811 \mathrm{C}>\mathrm{T}$ & p.Leu271Leu & exon 6 & 0.01 \\
\hline & c. $1110 G>A$ & p.Ala370Ala & exon 8 & 0.01 \\
\hline & c. $1131 \mathrm{C}>\mathrm{G}$ & p.Thr377Thr & exon 9 & 0.01 \\
\hline & C.1394_39 T>G & Intronic variant & intron 10 & 0.07 \\
\hline & c. 139414 C>T & Intronic variant & intron 10 & 0.01 \\
\hline & c. $1476 \bar{A}>G$ & p.Glu492Glu & exon 11 & 0.01 \\
\hline & C. $1590+14 \mathrm{~T}>\mathrm{C}$ & Intronic variant & intron 12 & 0.20 \\
\hline & C. $1638 \mathrm{G}>\mathrm{A}$ & p.Ser546Ser & exon 13 & 0.12 \\
\hline & c. $1685+36 \mathrm{G}>\mathrm{A}$ & Intronic variant & intron 13 & n.a. \\
\hline & C. $1732+43 T>C$ & Intronic variant & intron 14 & 0.19 \\
\hline & c. $1794+32$ G>T & Intronic variant & intron 15 & 0.06 \\
\hline & C. 1986 C>T & p.Tyr662Tyr & exon 16 & 0.35 \\
\hline \multirow[t]{7}{*}{ KCNH'2 } & c. $307+22 G>C$ & Intronic variant & intron 2 & 0.01 \\
\hline & c. $1467 \mathrm{C}>\mathrm{T}$ & p.lle489lle & exon 6 & 0.45 \\
\hline & C.1539 T>C & p.Phes13Phe & exon 6 & 0.43 \\
\hline & c. $1692 A>G$ & p.Leus64Leu & exon 7 & 0.50 \\
\hline & c. $1956 \mathrm{~T}>\mathrm{C}$ & p.Tyr652Tyr & exon 8 & 0.65 \\
\hline & c. $2690 \mathrm{~A}>\mathrm{C}$ & p.lys897Thr & exon 11 & 0.41 \\
\hline & c. $3152+22$ G>A & Intronic variant ${ }^{b}$ & intron 13 & 0.48 \\
\hline \multirow[t]{3}{*}{ KCNE1 } & c. $84 \mathrm{G}>\mathrm{A}$ & p.Ser28Ser & exon 3 & 0.02 \\
\hline & C. $112 A>G$ & p.Ser38Gly & exon 3 & 0.69 \\
\hline & c. $253 G>A$ & p.Asp85Asn & exon 3 & 0.03 \\
\hline \multirow[t]{2}{*}{ KCNE2 } & C.1_28 A>G & Intronic variant ${ }^{b}$ & intron 2 & 0.10 \\
\hline & c. $2 \overline{2} \mathrm{~A}>\mathrm{G}$ & p.Thr8Ala & exon 3 & 0.03 \\
\hline
\end{tabular}

The nucleotide numbering starts from the ATG start codon. Genbank accession numbers; AF000571 (KCNQ1), U04270 (KCNH2), M26685 (KCNE1) and NM005136 (KCNE2). Heterozygosity is based on the frequency in the patient population $(n=32)$, which is not unbiased. "A370A was found in a Japanese population freq.0.03 by Iwasa et al.[39]. 'Intronic variants previously reported by Larsen et al. [40].

To establish gene specific therapy, it is of major clinical importance to identify the gene defect involved. Due to reduced penetrance [41], gene defect carriers with normal QTc values do exist and these people may be at risk to develop life threatening ventricular arrhythmias. If the gene defect has been identified, drug administration can be used to protect gene defect carriers against these dangerous arrhythmias and sudden cardiac death might be prevented [42]. The incidence of LQTS is estimated at 1:10,000-15,000 of live births [43]. This indicates that in the Netherlands (with 16 million inhabitants), the incidence of LQTS will be more than 1000 individuals. Within two diagnostic centers (Maastricht and Amsterdam) we identified about 500 gene 
We conclude that the DHPLC analysis is a rapid, reliable, and highly sensitive mutation detection method which has been proven to be extremely useful to identify sequence aberrations in DNA samples even with a high GC content. We were able to identify several DNA alternations in the KCNQ1 gene, including a pathogenic missense mutation in a LQTS family, which was previously missed by SSCP analysis. This indicates an improvement in sensitivity of the mutation detection analysis (SSCP versus DHPLC) which is accordance with other investigations [23, 24, 25, 26, 27, 28]. However, when several SNPs are present in the tested fragment, DHPLC is perhaps not the method of choice.

Acknowledgements: This study was supported by the Interuniversity Cardiology Institute the Netherlands (ICIN) and the Cardiovascular Research Institute Maastricht (CARIM). We thank all the Dutch and the Belgian colleagues for sending biological samples to the Department of Genetics and Cell Biology, University Maastricht, in particular Prof. dr. A.A.M. Wilde, Drs. P. J. van Tintelen, Drs. I. van Langen, Dr. G. Matthijs, and Dr. C. Verellen, M.D. Ph.D.

\section{References}

1. Moss AJ, Zareba W, Benhorin J, Locati EH, Hall WJ, Robinson JL, Schwartz PJ, Towbin JA, Vincent GM, Lehmann MH. ECG T-wave patterns in genetically distinct forms of the hereditary long QT syndrome. Circulation. 1995; 92:2929-2934.

2. Romano C. Congenital cardiac arrhythmia. Lancet. 1965;1:658-659.

3. Ward OC. A new familial cardiac syndrome in children. J Irish Med Assoc. 1964; 54:103-106.

4. Schwartz PJ, Moss AJ, Vincent GM, Crampton RS. Diagnostic criteria for the long QT syndrome. An update. Circulation. 1993;88:782-784.

5. Jervell A, Lange-Nielsen F. Congenital deaf-mutism, functional heart disease with prolongation of the QT interval and sudden death. Am Heart J. 1957:54:59-68.

6. Fraser GR, Frogatt P, Murphy T. Genetical aspects of the cardio-auditory syndrome of Jervell and Lange-Nielsen (congenital deafness and electrocardiografic abnormalities). Ann Hum Genet. 1964:28:133-157.

7. Splawski I, Tristani-Firouzi M, Lehrmann $M H$, Sanguinetti M, Keating MT. Mutations in the hminK cause long QT syndrome and suppress Iks function. Nature Genet. 1997:17:338-340.

8. Schulze-Bahr E, Wang Q, Wedekind H, Haverkamp W, Chen Q, Sun Y. KCNE1 mutations cause Jervell and Lange-Nielsen Syndrome. Nature Genetics. 1997:17:267-268.

9. Splawski I, Shen J, Timothy KW, Lehmann MH, Priori S, Robinson JL, Moss AJ, Schwartz PJ, Towbin JA, Vincent GM, Keating MTI. Spectrum of mutations in long-QT syndrome genes. KVLQT1, HERG, SCN5A, KCNE1, and KCNE2. Circulation. 2000;102:1178-1185.

10. Schott JJ, Charpentier F, Peltier S, Foley P, Drouin E, Bouhour JB, Donneley P, Vergnaud G, Bachner L, Moisan JP, Le Marec H, Pascal O. Mapping of a gene for long QT syndrome to chromosome 4925-27. Am J Hum Genet. 1995:57:1114-1122.

11. Curran ME, Splawski I, Timothy KW, Vincent GM, Green ED, Keating MT. A molecular basis for cardiac arrhythmia: HERG mutations cause long QT syndrome. Cell. 1995;80:795-803.

12. Wang Q, Curran ME, Splawski I, Burn TC, Millholland JM, VanRaay TJ, Shen J, Timothy KW, Vincent GM, de Jager T, Schwartz PJ, Towbin JA, Moss AJ, Atkinson DL, Landes GM, Connors TD, Keating MT. Positional cloning of a novel potassium channel gene: KVLQT1 mutations cause cardiac arrhythmias. Nature Genet. 1996;12:17-23.

13. Wang Q, Shen J, Splawski I, Atkinson D, Li Zhizhong, Robinson JL, Moss AJ, Towbin JA, Keating MT. SCN5A mutations associated with an inherited cardiac arrhythmia, long QT syndrome. Cell. 1995;80:805-811. 
14. Tan HL, Bink-Boelens MT, Bezzina CR, Viswanathan PC, Beaufort-Krol GC, van Tintelen PJ, van den Berg MP, Wilde AA, Balser JR. A sodium-channel mutation causes isolated cardiac conduction disease. Nature. 2001;409:1043-1047.

15. Brugada P, Brugada R, Brugada J. The brugada syndrome. Curr Cardiol Rep. 2000;2:507-514.

16. Schott J, Alshinawi C, Kyndt F, Probst V, Hoorntje TM, Hulsbeek M, Wilde AA, Escande D, Mannens MM, Le Marec H. Cardiac conduction defects associate with mutations in SCN5A. Nature Genet. 1999:23:20-21.

17. Ackerman MJ, Siu BL, Sturner WQ. Tester DJ, Valdivia CR, Makielski JC, Towbin JA. Postmortem molecular analysis of SCNSA defects in sudden infant death syndrome. JAMA. 2001;286:2264-2269.

18. Vatta M, Dumaine R, Varghese G, Richard TA, Shimizu W, Aihara N, Nademanee K, Brugada R, Brugada J, Veerakul G, Li H, Bowles NE, Brugada P. Antzelevitch C. Towbin JA. Genetic and biophysical basis of sudden unexplained nocturnal death syndrome (SUNDS), a disease allelic to Brugada syndrome. Hum Mol Genet. 2002;11:337-345.

19. Abbott GW, Sesti F, Splawski I, Buck ME, Lehmann MH, Timothy KW, Keating MT, Goldstein SA MiRP1 forms IKr potassium channels with HERG and is associated with cardiac arrhythmia. Cell. 1999:97:175-187.

20. Orita M, Iwahana H, Kanazawa H, Hayashi K, Sekiya T. Detection of polymorphisms of human DNA by gel electrophoresis as single-strand conformation polymorphisms. Proc NatI Acad Sci. 1989;86:2766-2770.

21. O'Donovan MC, Oefner PJ, Roberts SC, Austin J, Hoogendoorn B, Guy C, Speight G, Upadhyaya M, Sommer SS, McGuffin Peter. Blind Analysis of Denaturating High-Performance Liquid Chromatography as a Tool for Mutation Detection. Genomics. 1998;52:44-49.

22. Underhill PA, Jin Li, Zemans R, Oefner PJ, Cavalli-Sporza LL. A pre-Columbian Y chromosome-specific transition and its implications for human evolutionary history. Pros Natl Acad Sci. 1993;93:196-200.

23. Wagner T, Stoppa-Lyonnet D, Fleischmann E, Muhr D, Pages S, Sandberg T, Caux V, Moeslinger R, Langbauer G, Borg A, Oefner P. Denaturing high-performance liquid chromatography detects reliably BRCA1 and BRCA2 mutations. Genomics. 1999;62:369-376.

24. Escary JL, Cecillon M, Maciazek J, Lathrop M, Tournier-Lasserve E, Joutel A. Evaluation of DHPLC analysis in mutational scanning of notch3, a gene with a high G-C content. Hum Mutat. 2000;16:518-526.

25. Buyse IM, Fang P, Hoon KT, Amir RE, Zoghbi HY, Roa BB. Diagnostic testing for rett syndrome by DHPLC and direct sequencing analysis of the MECP2 gene: identification of several novel mutations and polymorphisms. Am J Hum Genet. 2000;67:1428-1436.

26. van den Bosch BJ, de Coo RF, Scholte HR, Nijland JG, van Den Bogaard R, de Visser M, de DieSmulders CE, Smeets HJ. Mutation analysis of the entire mitochondrial genome using denaturing high performance liquid chromatograph. Nucleic Acids Res. 2000;28:E89.

27. Benit P, Kara-Mostefa A, Berthelon M, Sengmany K, Munnich A, Bonnefont JP. Mutation analysis of the hamartin gene using denaturing high performance liquid chromatography. Hum Mutat. 2000;6:417-421.

28. Xiao W, Oefner PJ. Denaturing High-Performance Liquid Chromatography: A review. Hum Mutat. 2001;17:439-474.

29. Jongbloed RJ, Wilde AA, Geelen JL, Doevendans P, Schaap C, Van Langen I, van Tintelen JP, Cobben JM, Beaufort-Krol GC, Geraedts JP, Smeets HJ. Novel KCNQ1 and HERG Missense Mutations in Dutch Long-QT families. Hum Mutat. 1999;13:301-310.

30. Van den Berg MH, Wilde AA, Robles de Medina EO, Meyer H, Geelen LM, Jongbloed RJ, Wellens HJ, Geraedts JP. The long QT syndrome: A novel missense mutation in the S6 region of the KVLQT1 gene. Hum Genet. 1997;100:356-361.

31. Splawski I, Shen J, Timothy K, Vincent G, Lehmann M, Keating M. Genomic structure of Three Long QT Syndrome Genes: KVLQT1, HERG and KCNE1. Genomics. 1998;51:86-97. 
32. Itoh T, Tanaka T, Nagai R, Kamiya T, Sawayama T, Nakayama T, Tomoike H, Sakurada H, Yazaki Y, Nakamura Y. Genomic organisation and mutational analysis of HERG, a gene responsible for familial long QT syndrome. Hum Genet. 1998;102:435-439.

33. Splawski I, Timothy K, Vincent G, Atkinson D, Keating M. Molecular basis of the long-QT syndrome associated with deafness. New Eng J Med. 1997;36:1562-1567.

34. Hecker $\mathrm{KH}$, Roux KH. High and Low Annealing Temperatures Increase Both Specificity and Yield in Tochdown and Stepdown PCR. Biotechniques. 1996;20:478-485.

35. Kupershmidt S, Snyders DJ, Raes A, Roden DM. A K+ channel splice variant common in human heant lacks a C-terminal domain required for expression of rapidly activating delayed rectifier current. , Biol Chem. 1998;273:27231-27235.

36. Larsen LA, Christiansen M, Vuust J, Andersen PS. A single strand conformatior, polymorphism/heteroduplex (SSCP/HD) method for detection of mutations in 15 exons of the KVLQT1 gene, assocated with long QT syndrome. Clinica Chimica Acta. 1999;280:113-125.

37. Kubota T, Shimizu W, Kamakura S, Horie M. Hypokalemia-induced long QT syndrome with an underlying novel missense mutation in \$4-S5 linker of KCNQ1. J Cardiovasc Electrophysiol 2000;11:1048-1054.

38. Sesti F, Abbott GW, Wei J, Murray KT, Saksena S, Schwartz PJ, Priori SG, Roden DM, George AL, Goldstein SA. A common polymorphism associated with antibiotic-induced cardiac arrhythmia. Proc Natl Acad Sci. 2000;97:10613-10618.

39. Iwasa $H$, Itoh $T$, Nagai R, Nakamura $Y$, Tanaka T. Twenty single nucleotide polymorphisms (SNPs) and their allelic frequencies in four genes that are responsible for familial long QT syndrome in the Japanese population. J Hum Genet. 2000;45:182-183.

40. Larsen L, Andersen P, Kanters I, Svendsen I, Jacobsen J,Vuust J, Wettrell G, Tranebjæarg L, Bàthèn J, Christiansen M. Screening for Mutations and Polymorphisms in the Genes KCNH2 and KCNE2 Encoding the Cardiac HERG/MiRP1 Ion Channel: Implications for Acquired and Congenital Long Q-T Syndrome. Clinical Chemistry. 2001;47:1390-1395.

41. Priori SG, Napolitano C, Schwartz PJ. Low penetrance in the long-QT syndrome: clinical impact. Circulation. 1999:99:529-533.

42. Schwartz PJ, Priori SG, Spazzolini C, Moss AV, Vincent M, Napolitano C, Denjoy Guicheney P, Breithard G, Keating MT, Towbin JA, Beggs AH, Brink P, Wilde AA, Toivonen L, Zareba W, Robinson J, Timothy KW, Corfield V, Wattanasirichaigoon D, Corbett C, Haverkamp W, Schulze-Bahr E, Lehmann MH, Schwartz K, Coumel P, Bloise R. Genotype-phenotype correlation in the long-QT syndrome: Gene-specific triggers for life-threatening arrhythmias. Circulation. 2001;103:89-95.

43. Ackerman MJ, Clapham DE. Ion channels; Basic science and clinical disease. New Engl J Med. 1997:336:1575-1586.

44. Le Gac G, Mura C, Ferec C. Complete scanning of the hereditary hemochromatosis gene (HFE) by use of denaturing HPLC. Clin Chem. 2001:49:1633-1640.

45. Le Marechal C, Audrezet MP, Quere I, Raguenes O, Langonne S, Ferec C. Complete and rapid scanning of the cystic fibrosis transmembrane conductance regulator (CFTR) gene by denaturing high-performance liquid chromatography (D-HPLC): major implications for genetic counselling. Hum Genet. 2001;108:290-298.

46. Conrath CE, Jongbloed RJE, van Langen IM, van Tintelen JP, Hauer RNW, Robles de Medina EO, Düren DR, Hoorntje TM, Lubbers U, Doevendans PAFM, Mannens MMAM, Geelen JLMC, Smeets HJM, Wilde AAM. Gene-specific distribution of cardiac events in LQTS1 and LQTS2. Cardiology. 1999;6:254-259. 


\section{5-1}

GENE SPECIFIC TRIGGERS IN LQTS

Auditory stimuli as a trigger for arrhythmic events differentiate HERGrelated (LQTS $)_{2}$ ) patients from KVLQT1-related patients (LQTS $)$

A.A.M. Wilde MD, R. J.E. Jongbloed, P.A. Doevendans MD, D.R. Düren MD, R.N.W. Hauer MD, I.M. van Langen MD, J.P. van Tintelen MD, H.J.M. Smeets PhD, H. Meyer PhD and J.L.M.C. Geelen PhD.

Journal of the American College of Cardiology 33:327-332 (1999) 


\section{ABSTRACT}

Objective. This study was performed to identify a possible relationship between genotype and phenotype in the congenital familial long QT syndrome (cLQTS). Background. The cLQTS, which occurs as an autosomal dominant or recessive trait, is characterized by QT-interval prolongation on the electrocardiogram and torsade de pointes arrhythmias, which may give rise to recurrent syncope or sudden cardiac death. Precipitators for cardiac events are exercise or emotion and occasionally acoustic stimuli. Methods. The trigger for cardiac events (syncope, documented cardiac arrhythmias, sudden cardiac death) was analyzed in 11 families with a familial LQTS and a determined genotype. Results. The families were subdivided in KVLQT1-related families (LQTS, $\mathrm{n}=5$ ) and HERG (human ether-a-gogo-related gene)-related families $\left(\right.$ LQTS $_{2}, \mathrm{n}=6$ ) based on single-strand conformation polymorphism analysis and sequencing. Whereas exercise-related cardiac events dominate the clinical picture of LQTS $_{1}$ patients, auditory stimuli as a trigger for arrhythmic events were only seen in $\mathrm{LQTS}_{2}$ patients. Conclusions. Arrhythmic events triggered by auditory stimuli may differentiate LQTS from LQTS, $_{1}$ patients.

The congenital familial long QT syndrome (cLQTS), which can occur as an autosomal dominant or recessive trait, is characterized by QT-interval prolongation on the electrocardiogram (ECG) and polymorphic ventricular arrhythmias (torsade de pointes). Torsade de pointes, syncope or sudden death usually occurs in relation to exercise or emotion, but occasionally also acoustic stimuli have been reported to elicit torsade de pointes [1- 3]. Based on linkage analysis, cLQTS is a genetically heterogeneous disease. Five loci have been identified [4- 9]. As LQTS families have been described that are not linked to these loci, additional loci must exist. Four genes have been identified: all these genes encode proteins that form (part of) ion channels [10, 11]. On chromosome 11p15.5 the gene KVLQT1 (or in the novel nomenclature KCNQ1) is located that encodes $I_{k s}$, the slowly activating component of the delayed rectifier (LQTS $;$; $[4,8]$ ). On 7935-36 HERG (human ether-a-gogo-related gene) resides encoding $I_{K r}$, the rapidly activating delayed rectifier (LQTS $;$ [5]) and on 21q21.1-22.2 the KCNE gene is located whose product co-assembles with that of KVLQT1 to form the $I_{\mathrm{ks}}$ channel (LQTS ; [9]). On chromosome 3p21-24 the gene for the $\mathrm{Na}^{*}$ channel $\alpha$-subunit, SCN5A involved in LQTS $_{3}$, is found [6]. Mutations in these genes result in abnormal prolonged repolarization, either by diminishing the repolarizing outward $\mathrm{K}^{*}$ currents or by an increase in the plateau inward $\left(\mathrm{Na}^{*}-\right)$ current $[10,11]$.

As ion channels have different time and voltage characteristics, the ECG-phenotype may be indicative for the gene involved. In particular, the late-appearing T-wave preceded by a long isoelectric segment in LQTS ${ }_{3}$ patients can be distinguished [12]. The ECGs of HERG-related LQTS, patients are characterized by low-amplitude T-waves in the extremity leads $[12,13]$. In addition, preliminary data from the LQT international 
registry demonstrate that the precipitator for arrhythmic episodes may also be genotype-specific [14]. Exercise-related events seem to dominate the clinical picture in LQTS $_{1}$ [14]. In contrast, cardiac events during sleep predominantly occur in LQTS, and are very rare in LQTS 1 [14, 15]. The LQTS 2 patients display a mixed pattern of triggers for arrhythmic events [14]. Acoustic stimuli have not separately been implied in these analyses. It is feasible that these clinical features correlate with the characteristics of the ionic currents affected.

In this study we analyzed the trigger for cardiac events (syncope, documented cardiac arrhythmias, sudden cardiac death [SCD]) in 11 families with a familial LQTS and a confirmed genotype. Whereas exercise-related cardiac events dominate the clinical picture of LQTS, patients, auditory stimuli as a trigger for arrhythmic events were only found in LQTS, patients. Hence, auditory stimuli may differentiate LQTS, from LQTS, patients.

\section{Methods}

Patients. The study was performed according to a protocol approved by the local ethics committee. Informed consent was obtained from all patients. All families came to our attention after unexpected cardiac death at a relatively young age ( $<40$ years) in one or more family members. Both ECGs and peripheral blood samples for genotype analysis were obtained from all symptomatic individuals and from as many family members as possible. In all symptomatic patients cardiac evaluation revealed prolonged QTintervals, and Romano-Ward syndrome was diagnosed because of normal hearing. Individuals with a positive genotype (see below) and individuals within these families who died suddenly and unexpectedly under the age of 40 years were defined as LQT patients (no ECGs were available in any of these patients). The trigger for eventual cardiac events (syncope, documented cardiac arrhythmias, SCD) was analyzed in all individuals. Triggers were subdivided into three categories: 1) (physical) exercise; 2) stress, emotion and anger; and 3) auditory stimuli (alarm clock, telephone ring, ambulance siren, and others).

Genotype analysis. Genomic DNA was extracted from peripheral blood lymphocytes by a high-salt extraction method [16]. Genomic fragments coding for the \$1-\$6 transmembrane domains (including the pore region) of the KVLQT1 gene [8] and the S1-S6 domains of HERG, including the pore and putative nucleotide binding domain, were amplified [5] on a Perkin-Elmer 9600 PCR (polymerase chain reaction) thermal cycler in the presence of $100 \mathrm{ng}$ forward and reverse primers, $0.2 \mathrm{mmol} / \mathrm{liter}$ deoxyribonucleotide, $1 \mathrm{U}$ Taq DNA polymerase (Gibco/BRL), $1.5 \mathrm{mmol} /$ liter $\mathrm{MgCl}_{2}$ and $100 \mathrm{ng}$ genomic DNA (volume $50 \mu \mathrm{l}$ ). Subsequently, PCR fragments were screened for single-strand conformation polymorphism (SSCP) variants using the GenePhor system (Pharmacia) and GeneGel Excell gels $12.5 / 24$. Gels were run at $10^{\circ} \mathrm{C}$ using 
manufacturer's standard conditions. The gels were silver-stained (Pharmacia PlusOne kit using an automatic stainer) and air-dried. Amplified products with aberrant SSCP bands were purified with PCR purification kit (Qiagen). The purified fragments were sequenced in both directions using the amplification primers. They were analyzed on a ABI-377 automatic sequencer (Perkin-Elmer) using Dye Terminator Cycle sequencing kit (Perkin-Elmer). For a detailed description of the methods employed, see Van den Berg et al. [17].

Statistical analysis. The presence of a specific trigger between the two groups of patients was compared by the Fischer exact test. Values of $p<0.05$ were considered significant.

\section{Results}

Out of the 18 families controlled in our centers, the genotype could be determined in 11. This analysis revealed five KVLQT1-related families ( 16 male and 26 female gene carriers; mutations identified Y184S, G189R in two families with a confounder in $\pm 1780, R 130 C$ and G345R) and six HERG-related families (8 male and 15 female gene carriers; mutations identified: A558P, R582C in two apparently unrelated families, G604S, T613M and F640L). The precipitator for syncope was evaluated in these genotyped families (Table 1). In 9 out of 15 symptomatic gene carriers in all six HERGbased families, acoustic stimuli were related to syncope. Although common, these auditory stimuli were not exclusively related to arousal. Figure 1 shows one of the episodes, triggered by an alarm clock. The arrhythmia is preceded by a "long-short" sequence based on ventricular extrasystoles. Five individuals in these HERG-related families died during sleep, one directly preceded by an acoustic stimulus and four without a known trigger (from one of them it was told that she could faint upon hearing the doorbell). In contrast to HERG-related patients, none of the 23 symptomatic carriers of a mutated KVLQT1 gene reported syncope related to auditory stimuli $(p<0.0001)$. Instead, in LQTS, patients, exercise was the predominant trigger ( $p$ $<0.0002$ ) and directly related to SCD in three young individuals (Table 1 ).

In one of the HERG families (genotype A558P) acoustic stimuli triggered loss of consciousness in three first-degree relatives; one of them died suddenly at the age of 22 upon arousal from sleep by an alarm clock. Figure 2 shows the onset of a rapid polymorphic ventricular arrhythmia shortly after arousal by an alarm clock in one of these individuals. Prior to the onset of the arrhythmia a slight increase in heart rate was noted. The quality of the registration does not allow careful description of the Twave morphology or duration measurement. The arrhythmia degenerated into ventricular fibrillation (VF) and the patient could be successfully defibrillated. 
Table 1. Precipitator of Cardiac Events in Symptomatic LQTS ${ }_{1}$ and LQTS Carriers

\begin{tabular}{|c|c|c|c|c|}
\hline & Exercise & Stress-Emotion, Anger & Acoustic & Unknown \\
\hline \multicolumn{5}{|l|}{ KVLQT1 (LQTS } \\
\hline (5 families) & $78 \%$ & $\begin{array}{c}9 \\
39 \%\end{array}$ & $0 \%$ & $\begin{array}{c}2 \\
9 \%\end{array}$ \\
\hline \multicolumn{5}{|l|}{ HERG (LQTS $)_{2}$} \\
\hline$n=15$ & 2 & 3 & 9 & 4 \\
\hline (6 families) & $13 \%$ & $20 \%$ & $60 \%$ & $27 \%$ \\
\hline
\end{tabular}

Precipitator of syncope as derived from the patients' history. Exercise relates to physical exercise. In one individual, more triggers and/or more than one type of acoustic stimulus might be present. Male-tofemale ratio was $9 / 14$ in KVLQT1 carriers and 4/11 in HERG carriers. The precipitator is unknown in six patients. Six LQTS, patients died suddenly, five of them during sleep (see text). Three young LQTS, patients died suddenly while exercising. Note that acoustic stimuli (in five patients an alarm clock, in five the doorbell, in three the telephone, and in one an ambulance siren) are only reported by LQTS, patients $(p<0.0001)$ and that exercise-related events predominantly occur in LQTS, patients ( $p$ < 0.0002).

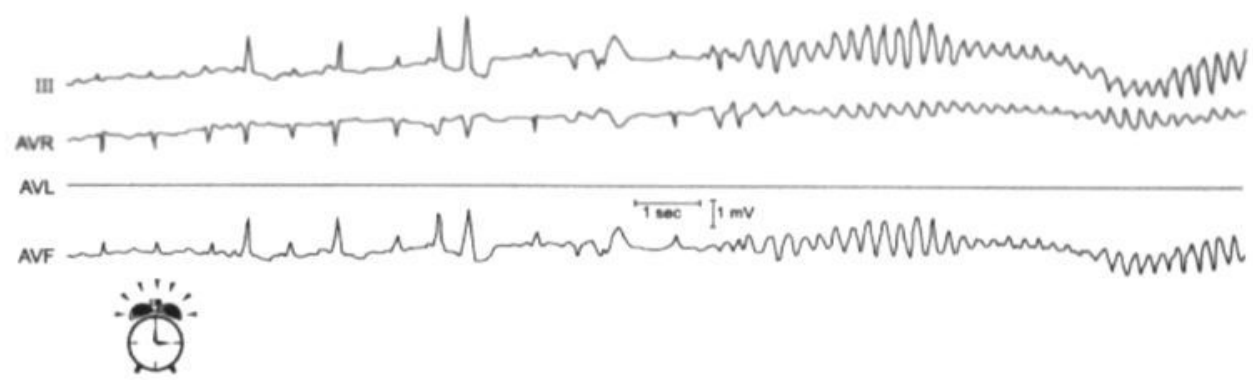

Figure 1.. Extremity leads of a ventricular arrhythmia upon sudden arousal at 3:00 by an alarm clock. The HERG mutation in this patient was G604S.

Figure 3 shows recordings (lead II, V2 and V5) of these three sibs (III-2, -3 and -4) and their father (II-5). No ECG had been recorded from the deceased patient. Markedly prolonged, terminally negative T-waves in the precordial leads were observed in patients III-2 and III-4. Individual III-3 and all other family members (not shown) were asymptomatic, and QT-intervals were all within normal range. Without exception, affected individuals met the criteria of a high probability for LQTS [18].

Treatment with beta-blockers was installed in 10 LQTS $_{2}$ patients and was successful in 8. Two patients developed torsades de pointes after many years ( $>10$ years) of successful treatment (while being heavily symptomatic before treatment was installed). Seven (asymptomatic) patients were not treated at all. Fourteen LQTS 1 patients were treated with beta-blockers, and in all of them treatment has thus far been successful; 24 patients were not treated (or refused treatment). One patient (female 84 years) has been treated for more than 30 years with diphantoin, and this treatment has not been changed after the genotype was established. 

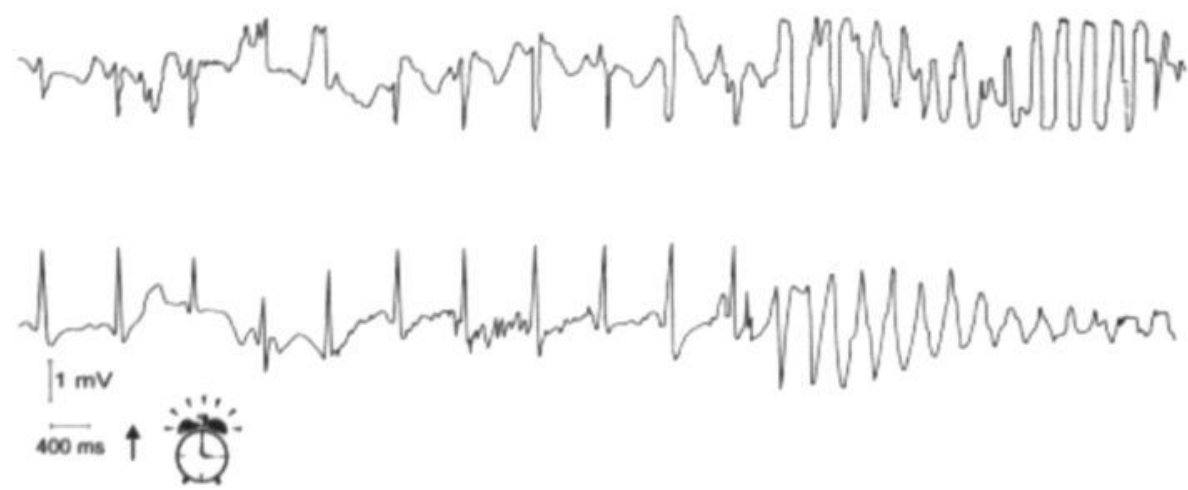

Figure 2. Ventricular arrhythmia upon sudden arousal at 3.00 by an alarm clock in a HERG patiert (A558P). The leads given are (approximately) V1 and II. See text for discussion.

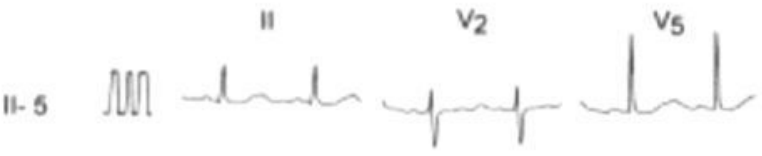

III-2

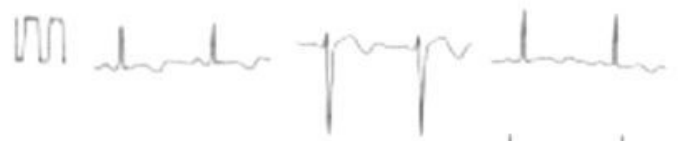

III-3

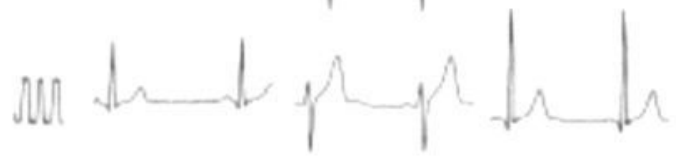

III-4

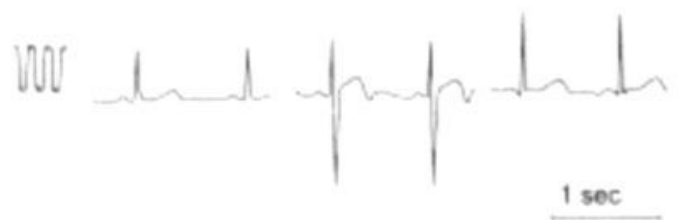

Figure 3. ECG recordings of the three sibs III-2, -3 and -4 and their father (II-5). Recordings from lead II, V2 and V5 have been selected. Abnormal, prolonged QT segments are present in patients II-5, III-2 and III-4. Calibrations are standard. The recording in Figure 2 is from patient III- 2 .

\section{Discussion}

cLQTS-related polymorphic ventricular arrhythmias most often occur in relation to exercise and emotion. The recent molecular analysis of the LQTS indicates that both the electrocardiographic repolarization pattern and the conditions during which 
arrhythmias develop might be genotype-specific [12-14]. All identified genes involved in the congenital LQTS code for (part of) ion channels involved in the repolarization process. They include KVLQT1 (LQTS $)$, KCNE (LQTS $)$ and HERG (LQTS $)$ encoding subunits of the slowly activating delayed rectifier $\left(I_{\mathrm{KS}_{\mathrm{S}}}\right)$ and the rapidly activating delayed rectifier $\left(I_{k_{1}}\right)$, respectively, and SCNSA (LQTS $)$ encoding the Na channel $\alpha$ subunit [4-9]. A mutation in an unknown gene on chromosome 4 is responsible for LQTS $_{4}$ described in a single French family [7]. Both LQTS ${ }_{1}$ and LQTS, are the most prevalent subtypes.

\section{Genotype-phenotype relationship}

Preliminary data on the relation between genotype and the trigger for arrhythmic events in patients included in the international LQTS registry [14] reveal that, in agreement with our data (Table 1), LQTS, arrhythmic events were frequently related to exercise $[14,19,20]$. Inadequate and transmurally nonuniform action potential shortening by $\beta$-adrenoceptor stimulation may underlie the associated high prevalence of arrhythmic events in these patients [21]. In contrast, LQTS 3 patients, not included in this study, experienced events during sleep [15]. In these patients cardiac repolarization may be fairly normal during fast rates due to the presence of normal K' currents. However, at rest, the incomplete inactivation of $\mathrm{I}_{\mathrm{Na}}$ (as a result of the mutation in the SCN5A gene) leads to abnormal repolarization [15]. Indeed, in experimental models mimicking LQTS $_{3}$ a fairly steep APD- and QT-rate relationship has been observed $[22,23]$. The LQTS 2 patients have an equally distributed pattern of precipitators (i.e., exercise, fright and emotion, and sleep). Acoustic stimuli as a trigger for arrhythmic events are not specifically cited in any previously mentioned study.

In this study we report on HERG-related CLOT families in which SCD, ventricular tachyarrhythmias and repeated syncope were preceded by auditory stimuli. In the patients with an auditory stimulus-related cardiac event, described in the literature, the genotype is unknown. In light of the available data on genotype specific ECG characteristics $[12,13]$, the markedly low T-wave amplitude in the extremity leads in the patients described by Wellens et al. [1] and by Shimizu et al. [2] might indicate a HERG-related defect.

Low T-wave amplitude in the extremity leads was also observed in our patients with HERG mutations (e.g., Fig.1). Documented arrhythmic episodes followed arousal by an alarm clock at 3 a.m. (Figure 1 and Figure 2). These episodes and those described previously [1 and 3] demonstrate that arrhythmias follow the stimulus within $10 \mathrm{~s}$. Between the alarm signal and the onset of the arrhythmia the T-wave might invert [ 1 and 3] and ventricular extrasystoles may appear ( [1, 3]; Fig. 1) giving rise to a "longshort"sequence resulting in more serious arrhythmias. This sequence is a common finding in LQTS patients [24]. 
Figure 2, however, shows that ventricular extrasystoles are not a prerequisite for the onset of potentially lethal arrhythmias. Further similarity in these patients is the predominant occurrence at night. In apparent conjunction, five individuals in HERrelated families experienced nocturnal death. A similar high incidence of nocturral death has been observed in other HERG-related families [25, 26, 27]. We found in LQTS $_{1}$ patients no acoustic stimuli in relation to disease-related events.

Based on the preceding evidence it is tempting to speculate that acoustic stimuli asa precipitator for arrhythmic events may differentiate LQTS from LQTS $_{1}$ patients. $n$ physiological terms an unexpected auditory stimulus is presumably equal to sudden fright, and a role for catecholamines is suggested. The sudden onset of the arrhythma, within seconds after the stimulus, precludes a systemic catecholamine effect or a catecholamine-related shift in the extracellular environment as basis for the arrhythmia. In agreement is the lack of changes in heart rate variability parametes just prior to the arrhythmic events [3]. The arrhythmic events occur at a relatively lov rate and not necessarily after a preceding sudden significant change in rate (Fig.2; EC; recordings in [1-3]). Hence, it seems fair to state that rate-dependent effects on the respective currents are not involved either.

Rather ، itseams 'mue ilkely thiat'a sudden release of local catecholamines triggers the event. Indeed, the sudden onset of ventricular extrasystoles originating from the terminal part of the grossly deformed T-waves is compatible with catecholamineinduced early afterdepolarizations (EADs) at a cellular level. The EADs have been recorded in LQTS patients upon exposure to (systemic) catecholamines [2 and 28]. Whereas in control patients isoproterenol shortens the (monophasic) action potential, a lengthening is observed in LQTS patients [28].

\section{Electrophysiological background}

Functional studies with HERG mutants expressed in Xenopus oocytes reveal complete loss of function for some mutants and dominant negative suppression of HERG function for others [29]. In an experimental cellular model mimicking a HERG defect (guinea pig ventricular cells exposed to a selective $I_{k r}$ blocker), $\beta$-adrenoceptor stimulation initially further lengthens the action potential and EADs develop [22]. After several minutes the action potential shortens, presumably due to catecholamineinduced $\mathrm{I}_{\mathrm{ks}}$ activation.

In contrast to $\mathrm{I}_{\mathrm{k},}, \mathrm{I}_{\mathrm{k} r}$ is insensitive to catecholamines [30]. In control cells and in cells pretreated with anthopleurin aimed to mimick a SCN5A defect by blocking $I_{\text {Na }}$ inactivation, isoproterenol shortens the action potential from the onset of exposure [22]. The KVLQT1 mutants similarly exert a dominant negative effect on $\mathrm{I}_{\mathrm{ks}}$ current [31]. Preliminary experimental data, using the specific [32] $I_{\mathrm{ks}}$ blocker chromanol 293B, 
reveal evidence that $\beta$-adrenoceptor stimulation results in a dramatic increase of transmural dispersion of repolarization and the development of ventricular arrhythmias most likely as a result of a large augmentation of residual $\mathrm{I}_{\mathrm{ks}}$ in epicardial and endocardial cells, but not in $\mathrm{M}$-cells where $\mathrm{I}_{\mathrm{ks}}$ is intrinsically weak [21]. Computer simulation studies on the role of $\mathrm{I}_{\mathrm{ks}}$ and $\mathrm{I}_{\mathrm{k} r}$ in cardiac repolarization in a guinea-pig ventricular cell-based model reveal that a decrease in $I_{\mathrm{ks}}$ conductance of $>80 \%$ prevents cardiac repolarization completely [33]. The $I_{k r}$ reduction does lengthen the action potential but does not result in EADs [33].

Based on these results, obtained in a model in which compared to human cells several important repolarizing currents are not present (among which the transient outward current), it is postulated that the ratio $I_{\mathrm{ks}} / \mathrm{I}_{\mathrm{kr}}$ is of particular importance with regard to the development of EADs [33]. Although both currents have been shown in isolated (right) ventricular myocytes [34], no detailed information is available on its ratio and distribution.

\section{Conclusions}

The presence of acoustic stimuli as a trigger for arrhythmic events may differentiate LQTS $_{2}$ from LQTS, patients. The absence of SCN5A- and KCNE-related patients precludes a statement that acoustic stimuli can be considered characteristic for LQTS Although this observation ought to be confirmed by larger studies, it seems that, based on the prevalence of the LQTS subtypes, the presence of auditory stimuli should direct molecular genetic analysis toward HERG.

\section{References}

1. H.J.J. Wellens, A. Vermeulen and D. Durrer, Ventricular fibrillation occurring on arousal from sleep by auditory stimuli. Circulation. 1972; 46:661-665.

2. W. Shimizu, T. Ohe, T. Kurita, T. Tokuda and K. Shimomura, Epinephrine-induced ventricular premature complexes due to early afterdepolarizations and effects of verapamil and propranolol in a patient with congenital long QT syndrome. J Cardiovasc Electrophysiol. 1994:5:438-444.

3. T. Nakajima, K. Misu, K. Iwasawa et al., Auditory stimuli as a major cause of syncope in a patient with idiopathic long QT syndrome. Jpn Circ J. 1995;59:241-246.

4. M.T. Keating, D.L. Atkinson, C. Dunn, K.W. Timothy, G.M. Vincent and M. Leppert, Linkage of a cardiac arrhythmia, the long QT syndrome, and the Harvey ras-1 gene. Science. 1991;252:704-706.

5. M.E. Curran, I. Splawski, K.W. Timothy, G.M. Vincent, E.D. Green and M.T. Keating, A molecular basis for cardiac arrhythmia: HERG mutations cause long QT syndrome. Cell. 1995;80:795-803.

6. Q. Wang, J. Shen, I. Splawski et al., SCN5A mutations associated with an inherited cardiac arrhythmia, long QT syndrome. Cell. 1995;80:805-811.

7. JJ. Schott, F. Charpentier, S. Peltier et al., Mapping of a gene for long QT syndrome to chromosome 4q25-27. Am J Hum Genet. 1995;57:1114-1122.

8. Q. Wang, M.E. Curran, I. Splawski et al., Positional cloning of a novel potassium channel gene: KvLQT1 mutations cause cardiac arrhythmias. Nat Genet. 1996;12:17-23. 
9. I. Splawski, M. Tristani-Firouzi, M.H. Lehmann, M.C. Sanguinetti and M.T. Keating, Mutations in the hminK gene cause long QT syndrome and suppress $I_{\mathrm{ks}}$ function. Nat Genet. 1997;17: 338-340.

10. R.S. Kass and M.P. Davies, The roles of ion channels in an inherited heart disease: molecular genetics of the long QT syndrome. Cardiovasc Res. 1996;32: 443-454.

11. D.M. Roden, R. Lazzara, M. Rosen et al., Multiple mechanisms in the long QT syndrome. Current knowledge, gaps, and future directions. Circulation. 1996;94:1996-2012.

12. A.J. Moss, W. Zareba, J. Benhorin et al., ECG T-wave patterns in genetically distinct forms of the hereditary long QT syndrome. Circulation. 1995;92:2929-2934.

13. E. Schultze-Bahr, W. Haverkamp, G. Breithardt, H. Funke, H. Wiebusch and G. Assmann, ECG repolarization patterns in chromosome 7-linked QT syndrome (LQTS 2). Circulation. 1996;94:2318-2319.

14. Schwartz PJ, Moss AJ, Priori SG, et al. Gene-specific influence on the triggers for cardiac arrest in the long QT syndrome [abstract]. Circulation. 1997;96:1-212.

15. P.J. Schwartz, S.G. Priori, E. Locati et al., Long QT syndrome patients with mutations of the SCN5A and HERG genes have differential responses to $\mathrm{Na}^{*}$ channel blockade and to increases in heart rate. Circulation. 1995:92:3381-3386.

16. R. Müllerbach, P.J.L. Lagoda and C. Welter, An efficient salt-chloroform extraction of DNA from blood and tissues. Trends Genet. 1989;5: 391.

17. M.H. Van den Berg, A.A.M. Wilde, E.O. Robles de Medina et al., The long QT syndrome: a novel missense mutation in the S6 region of the KVLQT1 gene. Hum Genet. 1997;100:356-361.

18. P.J. Schwartz, A.J. Moss, G.M. Vincent and R.S. Crampton, Diagnostic criteria for the long QT syndrome: an update. Circulation. 1993;88:782-784.

19. G.M. Vincent, K.W. Timothy, M. Leppert and M.T. Keating, The spectrum of symptoms and QT intervals in carriers of the gene for the long QT syndrome. N Engl J Med. 1992; 327:846-852.

20. T. de Jager, C.H. Corbett, J.C.W. Badenhorst, P.A. Brink and V.A. Corfield, Evidence of a long QT founder gene with varying phenotypic expression in South African families. J Med Genet. 1996;33: 567-573.

21. W. Shimizu and C. Antzelevitch, Cellular basis for the electrocardiographic features of the LQT1 form of the long QT syndrome: effects of $\beta$-adrenergic agonists, antagonists and sodium channel blockers on transmural dispersion of repolarization and torsades de pointes [abstract]. J Am Coll Cardiol. 1998;31: 2A.

22. S.G. Priori, C. Napolitano, F. Cantu, A.M. Brown and P.J. Schwartz, Differential response to Na' channel blockade, $\beta$-adrenergic stimulation, and rapid pacing in a cellular model mimicking the SCNSA and HERG defects present in the long QT syndrome. Circ Res. 1996;78:1009-1015.

23. W. Shimizu and C. Antzelevitch, Sodium channel block with mexiletine is effective in reducing dispersion of repolarization and preventing torsades de pointes in LQT2 and LQT3 models of the long QT syndrome. Circulation. 1997; 96:2038-2047.

24. S. Viskin, S.R. Alla, H.V. Barron et al., Mode of onset of torsades de pointes in congenital long QT syndrome. J Am Coll Cardiol. 1996;28:1262-1268.

25. E. Dausse, M. Berthet, I. Denjoy et al., A mutation in HERG associated with notched T-waves in long QT syndrome. J Mol Cell Cardiol. 1996;28:1609-1615.

26. Timothy KW, Zhang L, Meyer KJ, Vincent GM. Differences in precipitators of cardiac arrest and sudden death in chromosome 11 versus 7 genotype long QT syndrome patients [abstract]. Circulation. 1996;94:1-204.

27. Napolitano C, Priori SG, Schwartz PJ, et al. Identification in a mutational hot spot in HERG-related long QT syndrome (LQT2): phenotypic implications [abstract]. Circulation. 1997;96:1-212.

28. W. Shimizu, T. Ohe, T. Kurita et al., Early afterdepolarizations induced by isoproterenol in patients with congenital long QT syndrome. Circulation. 1991;84:1915-1923.

29. M.C. Sanguinetti, M.E. Curran, P.S. Spector and M.T. Keating. Spectrum of HERG K'-channel dysfunction in an inherited cardiac arrhythmia. Proc Natl Acad Sci USA. 1996;93:2208-2212. 
30. M.C. Sanguinetti, N.K. Jurkiewicz, A. Scott and P.K.S. Siegl, Isoproterenol antagonizes prolongation of refractory period by the class III antiarrhythmic agent E-4031 in guinea pig myocytes: mechanism of action. Circ Res. 1991;68:77-84.

31. C. Chouabe, N. Neyroud, P. Guicheney, M. Lazdunski, G. Romey and J. Barhanin, Properties of KvLQT1 $\mathrm{K}^{*}$ channel mutations in Romano-Ward and Jervell and Lange-Nielsen inherited cardiac arrhythmias. EMBO J. 1997; 16:5472-5479.

32. R.F. Bosch, R. Gaspo, A.E. Busch, H.J. Lang, G.R. Li and S. Nattel, Effects of the chromanol 2938, a selective blocker of the slow component of the delayed rectifier $\mathrm{K}^{*}$ current, on repolarization in human and guinea pig ventricular myocytes. Cardiovasc Res. 1998;38:441-450.

33. J. Zeng, K.R. Laurita, D.S. Rosenbaum and Y. Rudy, Two components of the delayed rectifier $K^{\circ}$ current in ventricular myocytes of the guinea pig type: theoretical formulation and their role in repolarization. Circ Res. 1995;77:140-152.

34. G. Li, J. Feng, L. Yue, M. Carrier and S. Nattel, Evidence for two components of delayed rectifier K' current in human ventricular myocytes. Circ Res. 1996;78: 689-696. 



\section{5-2}

GENE SPECIFIC TRIGGERS IN LQTS

Gene-specific distribution of cardiac events in LQTS1 and LQTS2

C.E. Conrath, R.J.E. Jongbloed, I.M van Langen, J.P. van Tintelen, R.N.W.Hauer, E.O. Robles de Medina, D.R. Düren, T.M. Hoorntje, L.J. Lubbers, P.A.F.M. Doevendans, M.M.A.M. Mannens, J.L.M.C. Geelen, H.J.M. Smeets, A.A.M.Wilde.

Cardiologie 6:254-259 (1999) 


\section{Abstract}

Background. Genotype-phenotype relations have recently been described in patients with the long QT syndrome (LQTS). Therefore we analysed the triggers for cardiac events in our patients. Methods. We studied the triggers for cardiac events in a genotyped population, consisting of 15 families and two solitary cases. Eight families (61 patients) and one solitary patient were affected with LQTS ${ }_{1}$, seven families (35 patients) and one isolated case with LQTS $_{2}$. In individual patients more than one trigger could be present. Furthermore, the age of onset of symptoms was determined. Results. In the LQTS ${ }_{1}$ group, 29 of 62 mutation carriers were symptomatic. Five of these patients died suddenly. Physical stress was a trigger for cardiac events in 25/29 patients. This was related to exercise in 21 patients and to diving or swimming in 15 patients. In 9/29 patients emotional stress was a trigger for cardiac events. One patient showed symptoms at rest, and in one patient the trigger was unknown. In the $\mathrm{LQTS}_{2}$ group, 18 of 36 mutation carriers were asymptomatic. Six died suddenly, five of them at night. Events related to physical stress occurred in $2 / 18$ patients (related to exercise in both patients, not to swimming), and to emotional stress in $6 / 18$ patients. Sudden arousal was a trigger in 14 patients. An acoustic stimulus was mostly present, but not obligatory. In 12 patients an acoustic stimulus was related to cardiac symptoms, solely in combination with sudden arousal in at least five patients. In 3/18 patients, the trigger was unknown. In LQTS, four children became symptomatic under the age of five, 11 at five or six years of age, and 11 patients between the ages of 7 and 13. In 13 of 18 LQTS $_{2}$ patients in whom the age of onset of symptoms was known, no patients became symptomatic under 9 years of age. Four children became symptomatic between the ages of 9 and 13. In LQTS, patients events predominantly occurred in relation to exercise and emotion, whereas in LQTS, patients events often triggered by sudden arousal, mostly due to an acoustic stimulus, and by emotion. Furthermore, LQTS, patients became symptomatic at a younger age than LQTS, patients. Conclusion. Clinical presentation of patients with long QT syndrome is largely genotype specific, and clinical criteria may be used for specific molecular testing.

Congenital familial long-QT syndrome (cLQTS) is characterized by QT-interval prolongation on the ECG and polymorphic ventricular arrhythmias (torsade de pointes) which may lead to syncope and sudden cardiac death. There is a classic subdivision of CLQTS into Romano-Ward syndrome with a (usually) autosomal dominant inheritance, and Jervell and Lange-Nielsen syndrome, inherited as a autosomal recessive trait and associated with congenital deafness. In recent years it has become clear that the molecular basis of cLQTS is heterogeneous. Until now, five chromosomal loci and four genes have been identified [1-6]. This genetic information forms the basis of the present subdivision in LQTS, LQTS ${ }_{2}$, etc. KVLQT1 (or KCNQ1 in the novel nomenclature) is the gene involved in LQTS ${ }_{1}$, and, amongst others, in Jervell and Lange-Nielsen 
syndrome. Its chromosomal location is the distal end of the short arm of chromosome 11 (in code 11p15.5, p=short arm). HERG, the gene involved in LQTS long arm of chromosome 7 (7q35-36; $q=$ long arm). Together, KVLQT1 and HERG account for about $70 \%$ of affected families. The proteins encoded by these genes assemble into tetramers to form functional potassium channels, with or without other (regulatory) units encode by different genes. One of these regulatory units has been shown to be involved in LQTS, (the KCNE1 gene on chromosome 21q21.1-22.2)[6]. The gene for the cardiac $\mathrm{Na}^{+}$channel $\alpha$-subunit SCN5A, involved in LQTS chromosome 3p21-24 [3]. Mutations in these genes may result in decreased repolarizing outward $\mathrm{K}^{*}$ currents $\left(\operatorname{LQTS}_{1,2}\right.$ s. $_{\text {) }}$ or in an increase in the plateau inward current (LQTS $)$. Te final common pathway is an abnormally prolonged repolarization as evidenced by the log QT interval on the ECG $[7,8]$. Based on different characteristics of the ion channels involved, the phenotype of the patients and/ or families may be indicative of the gene involved. Indeed, preliminary evidence suggests that both the ECG and the trigger for arrhythmic events may be genotype-specific [9-12].

In this study we tested the hypothesis that the clinical presentation of patients with LQTS is indicative of the type of LQTS. Therefore the trigger for cardiac events (syncope, documented cardiac arrhythmias, sudden cardiac death) was analyzed in 15 families with a familial LQTS and in two individual patients with LQTS (in whom a specific cause for the LQTS other than the genetic defect could be excluded). Our data suggest that the clinical presentation is indeed indicative of the specific gene involved in the disease.

\section{Methods}

Patients. The study was performed according to a approved by the local ethic committee. Written informed consent was obtained from all patients. All genotyped families followed to our centers were included. The families $(n=15)$ and isolated patients $(n=2)$ came to our attention after unexplained cardiac death at a relatively young age ( $<40$ years) in one or more family members, or after LQTS was diagnosed in a symptomatic individual. All symptomatic patients had normal hearing, hence Jervell and Lange-Nielsen syndrome could be excluded. When no ECG was available for an individual within these families, they were defined as having LQTS if they had died suddenly and unexpectedly under the age of forty. Symptomatic individuals with a prolonged QT interval and a negative family history $(n=2)$ were classified as congenital LQTS whenever a specific reason for prolongation of the QT interval could be excluded (i.e. no QT-prolonging drugs, electrolyte disturbances, mitral valve prolapse, acute cerebrovascular accidents, etc.). A careful history, an ECG, and peripheral blood samples for genomic analysis were taken from all symptomatic individuals and from as many family members as possible. Cardiac events were determined by history for all proven mutation carriers, obligate carriers (family members that by pedigree analysis 
were determined carriers of the mutated gene), deceased family members. The distribution of triggers within the genetically distinct groups was studied. Only the gene involved was related to the distribution of triggers. The specific mutations that were found in our patients were not analyzed for genotype-phenotype relations, as our patient group was not large enough to discriminate between possibly distinct phenotypes of the mutations involved. Events could be related to physical stress, which was subdivided into exercise and diving and/ or swimming, to emotional stress, to sudden arousal, to an acoustic stimulus, or they could have occurred at rest. In some patients, cardiac events occurred in relation to multiple stimuli. The average age of the symptomatic patients was computed. Furthermore, the age at onset of symptoms was determined for the genetically distinct groups.

Genotype analysis. Blood samples were collected from all patients. The genomic DNA was extracted from peripheral blood lymphocytes. ${ }^{13}$ PCR amplification was performed of the coding regions of the KVLQT1 gene and the HERG gene (Perkin Elmer 9600 PCR thermal cycler). These fragments were analysed for SSCP variants, using the GenePhor system (Pharmacia) and GeneGel Excell 12.5/24. Gels were run at two different temperatures, $5{ }^{\circ} \mathrm{C}$ and $15{ }^{\circ} \mathrm{C}$, silver stained and air dried. Fragments displaying aberrant SSCP bands were purified using Qiagen PCR purification kit, and sequenced on an ABI-377 automatic sequencer (Perkin Elmer), using the amplification primers as sequencing primers. The Dye Terminator Cycle sequencing kit (Perkin Elmer) was used for this purpose.

\section{Results}

The pedigree of one of the families is given in figure 1 . This family came to our attention in 1997, shortly after the death of a 6-year-old girl (III-7). After one syncopal episode shortly after diving the swimming pool in May 1997, she died in June 1997 under swimming circumstances. Post-mortem examination revealed no specific cause for her death. Several weeks after this tragic event a ten year-old cousin (III-4) experienced a syncope during exercise. Subsequent in-hospital evaluation revealed a prolonged QT interval and a familial LQTS was suggested. The family history further revealed that the mother of the deceased child (II-7) had been treated for an aspecific epilepsy during childhood until adolescence. Symptoms started at the age of six. Her brother (II-4), the father of the symptomatic boy, recalled three syncopes in his youth related to exercise. The first episode took place at the age of 14. Their eldest sister (II-3) had suffered from syncope since childhood, which became exercise dependent later in life. Prolonged QT intervals were present on the ECGs of these three individuals. The other first-degree relatives had no complaints and both parents (I-1 and I-2) appeared healthy at old age. Genetic analysis in family revealed a mutation in the KVLQT1 gene, resulting in an amino acid substitution at position 184 (Tyr184Ser). 
The trigger for syncope was further evaluated in 14 other congenital LQTS families and two individual patients followed in our centres (Figure 2). In some patients, symptoms were triggered by multiple stimuli. In eight families (including the family described above), consisting of 61 mutation carriers, and in one individual patient a mutation was found in the KVLQT1 gene (LQTS $)$. In seven families, consisting of 35 mutation carriers, and in one individual patient we found a mutation in the HERG gene (LQTS $)_{2}$.

Symbol definitions

$\square$ Clear symbol

- knot 1-mutation

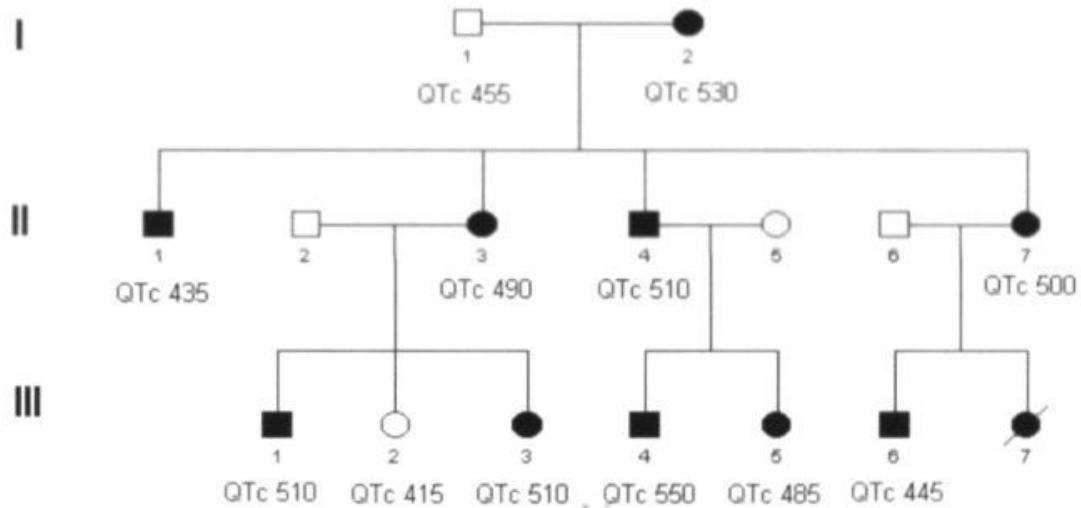

Figure 1. Pedigree of a family affected with LQTS . In this family a mutation was found in the KVLQT1 gene, leading to an amino acid substitution at position 184 (Tyr184Ser). QT intervals corrected for heart rate were added. See text for further details.

The LQTS 5 -related KCNE1 gene was analysed in all index patients, except for one LQTS patient, by sequencing analysis. No mutations were found in this gene. (Jongbloed, personal communication). The LQTS - -related gene has not yet been identified, but linkage data provided no evidence for involvement of this gene in our families. Of 62 mutation carriers with LQTS, $29(47 \%)$ were symptomatic (14 male, 15 female; average age of patients alive $35 \pm 19$ years) Twenty-five patients (25/29) showed symptoms in relation to physical stress, related to exercise in 21 patients and to diving/swimming in 15 patients. An example is given in figure 3 . In 9 patients (9/29) emotional stress was a trigger for cardiac events, and one patient had an event at rest. No patients showed cardiac symptoms in relation to sudden arousal or to acoustic stimuli. The trigger for arrhythmias was unknown in one patient. In 36 individuals with genotyped LQTS, 18 patients (50\%) were symptomatic ( 5 male,13 female; average age of the patients alive $37 \pm 12$ years, the age was unknown in two patients). Six of the symptomatic family members died, five of them reportedly at night. Cardiac events 
related to physical stress were present in 2 of 18 symptomatic patients (related to exercise, not related to diving/swimming), to emotional stress in 6 patients (6/18), and to sudden arousal in 14 patients (14/18) mostly due to an acoustic stimulus. An acoustic stimulus was identified as a trigger in 12 patients, only in combination with sudden arousal in at least five of them. In three patients (3/18) the trigger for cardiac events was unknown. The number of asymptomatic patients seems rather high, $53 \%$ in the LQTS ${ }_{1}$ group and $50 \%$ in the LQTS, group. This would indicate a rather low penetrance in our LQTS population.

\section{Distribution of symptoms}

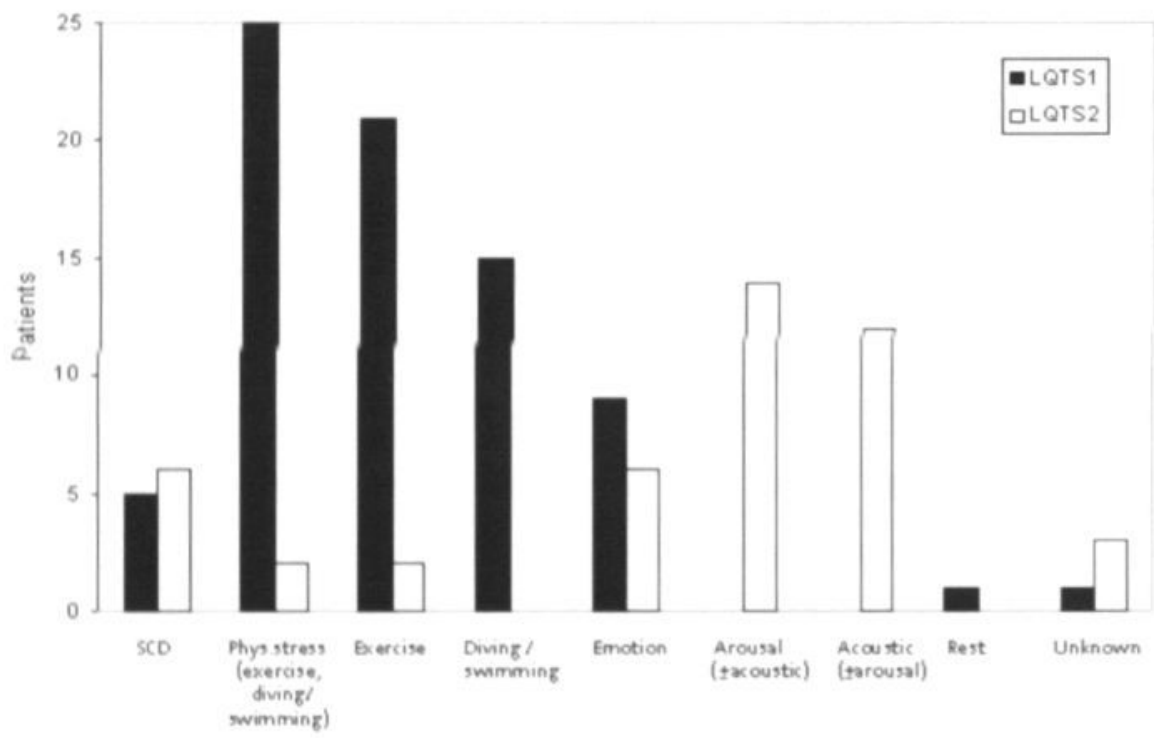

Figure 2. The distribution of symptoms in a genotyped LQTS population is graphically displayed. In an individual patient multiple stimuli may lead to cardiac events. The $Y$ axis displays the number of patients involved. On the $X$ axis different stimuli that lead to arrhythmic events are represented. The number of patients who died suddenly is also shown here ( $\mathrm{SCD}=$ sudden cardiac death). Physical stress as a trigger for symptoms was subdivided into exercise and diving/ swimming. In at least five patients who had symptoms in relation to an acoustic stimulus, events only occurred when that stimulus was associated with sudden arousal. In other patients the sound of e.g. a ringing telephone or an ambulance siren could be a trigger for cardiac events as well.

The median of the age of onset of symptoms in the LQTS, group (known in all 29 patients) was 6 years (mean 9.2 years, SD 8.6 years). In four patients, symptoms started under the age of five, in 11 patients at the age of five or six, and in 11 patients between the ages of 7 and 13 . In 13 of 18 LQTS $_{2}$ patients in whom the age of onset as unknown, the median of the age at which symptoms occurred for the first time was 17 
years (mean 15.5 years, SD 4.1 years). None of the patients showed symptoms before the age of 9 . Four patients became symptomatic between the ages of 9 and 13 .

\section{Discussion}

LQTS is a syndrome characterised by the prolongation of the QT interval and by polymorphic ventricular arrhythmias (torsade de pointes) type, figure 3 ), giving rise to recurrent syncope and sudden cardiac death. Recently, multiple functionally related genes have been identified $[2,3,5,6]$. These genes encode for proteins involved in the depolarisation process. LQTS ${ }_{1.2 .5}$ are based on mutations in the KVLQT1, HERG, and KCNE1 genes which encode for (subunits of) potassium channels in the cell membrane. Mutations in the SCN5A gene encoding the $\alpha$-subunit of the cardiac $\mathrm{Na}^{+}$channel, are involved in LQTS . The gene related to LQTS, that has been mapped to chromosome 4. has not yet been identified [4].

Because ionic currents have different time and voltage characteristics, it may be speculated that the phenotype is characteristic for the underlying gene defect. indeed, clinical differences in genetically distinct forms of long QT syndrome were found. In our LQTS, population, cardiac events were mainly triggered by exercise, in particular diving/swimming. In patients with $\mathrm{LQTS}_{2}$, cardiac events also occurred at night, most often in relation to sudden arousal. (The data presented in this paper include the patients described in the paper by Wilde et al [14]. Differences in patient statistics are due to an enlargement of the patient group.) Although most often present, a loud acoustic stimulus was not obligatory. Occasionally the acoustic stimulus alone (not leading to sudden arousal at night) was sufficient to elicit cardiac arrhythmias. Further, emotion and stressful events frequently triggered loss of consciousness in $\mathrm{LQTS}_{2}$ patients. Preliminary data from the LQTS registry involving larger numbers of affected patients are in accordance with our findings [11]. Patients suffering from LQTS $_{1}$ became symptomatic at an earlier age than patients suffering from LQTS 2 . In

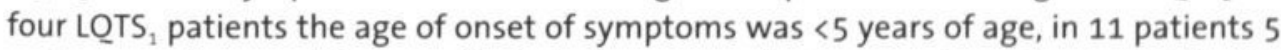
or 6 years of age, and in 11 patients between 7 and 13 years of age. In 13 of 18 LQTS $_{2}$ patients in whom the age at onset was known, no children under the age of 9 had suffered from cardiac events. Between 9 and 13 years of age, 4 children became symptomatic. Zareba et al [15]. found a similar difference in the age of onset of symptoms. Finally, Moss et al. ${ }^{9}$ showed genotype specific ECG patterns for LQTS ${ }_{1,2}$ and LQTS .

Exercise is a particularly important trigger for cardiac events, especially linked to mutations in KVLQT1 (LQT, and Jervell and Lange-Nielsen syndrome; this study,) [11]. $I_{\text {Ks }}$, the current related to the channel of which components are encoded by KVLQT1 and KCNE1, is responsible for the final repolarization phase. This current is highly sensitive to catecholamines. An increase in heart rate requires an enhanced repolarization rate, and increased amplitude of $I_{k s}$ is likely to account for this. 
Inhomogeneous adaptation of the action potential duration to an increase in rate, secondary to dysfunctioning mutant $I_{\mathrm{ks}}$ channels, may account for the enhanced propensity for arrhythmias during exercise. Swimming, and in particular diving, is an important stressor in LQTS, patients (Figure 2). It may be postulated that diving is equivalent to a Vasalva manoeuvre, with an increase in heart rate, following the initial bradycardia. Once again, the improper adaptation of the action potential duration may lead to heterogeneity in repolarisation with subsequent triggered arrhythmias. A common denominator of all these conditions is catecholamine release, locally and / or systemically.

LQTS 2 patients exhibit cardiac events related to exercise as well, but also to stress, emotion, anger, and particularly acoustic stimuli with or without sudden arousal. Typically, an acoustic stimulus is followed by the arrhythmia within seconds [14]. Hence, local catecholamine release of systemically released catecholamines seems pertinent to the initiation of arrhythmias in these patients. In a HERG experimental model (cardiac myocytes exposed to pharmacological HERG inhibition, i.e. most 'class III' drugs), catecholamine exposure leads to a biphasic response: an initial marked prolongation of the action potential duration is followed by sustained shortening [16]. This initial prolongation, in particular when it occurs inhomogeneously, may, underlie the arrhythmogeneity in HERG-mutated patients. In SCN5A patients, events predominantly occur at rest [11]. It is postulated that at slow heart rate, repolarisation is hampered by a sustained inward current secondary to incomplete inactivation of the mutant sodium channels. At a faster heart rate, the increased contribution of (normal) $\mathrm{K}^{*}$ currents may overcome the persistent inward $\mathrm{Na}^{+}$current.

In conclusion, this study showed a genotype-phenotype relation in patients with LQTS. The trigger for symptoms may indicate the genetic origin of the disease. Occurrence of cardiac events after sudden arousal was only found in LQTS 2 patients, whereas events related to physical stress occurred predominantly in LQTS, patients. In the latter patient group, events related to physical stress were often common denominator of all these conditions is catecholamine release, locally and/or systemically related to swimming. In addition, LQTS ${ }_{1}$ patients showed symptoms at a younger age than LQTS patients, which indicates that early treatment may be more important in children affected with LQTS.

Analyzing the genotype-phenotype relation in patients with LQTS may eventually lead to a more efficient search for the underlying genetic defect, as the presumably affected gene will be the first target for mutation analysis. In addition, a gene specific treatment, i.e. $\beta$-blockade in LQTS, (and LQTS $)_{2}$ ) patients, and sodium channel blockers or pacemaker therapy in LQTS, patients, may be indicated. Gene specific treatment is the subject of clinical trials currently being performed in patients included in the LQTS registry. 

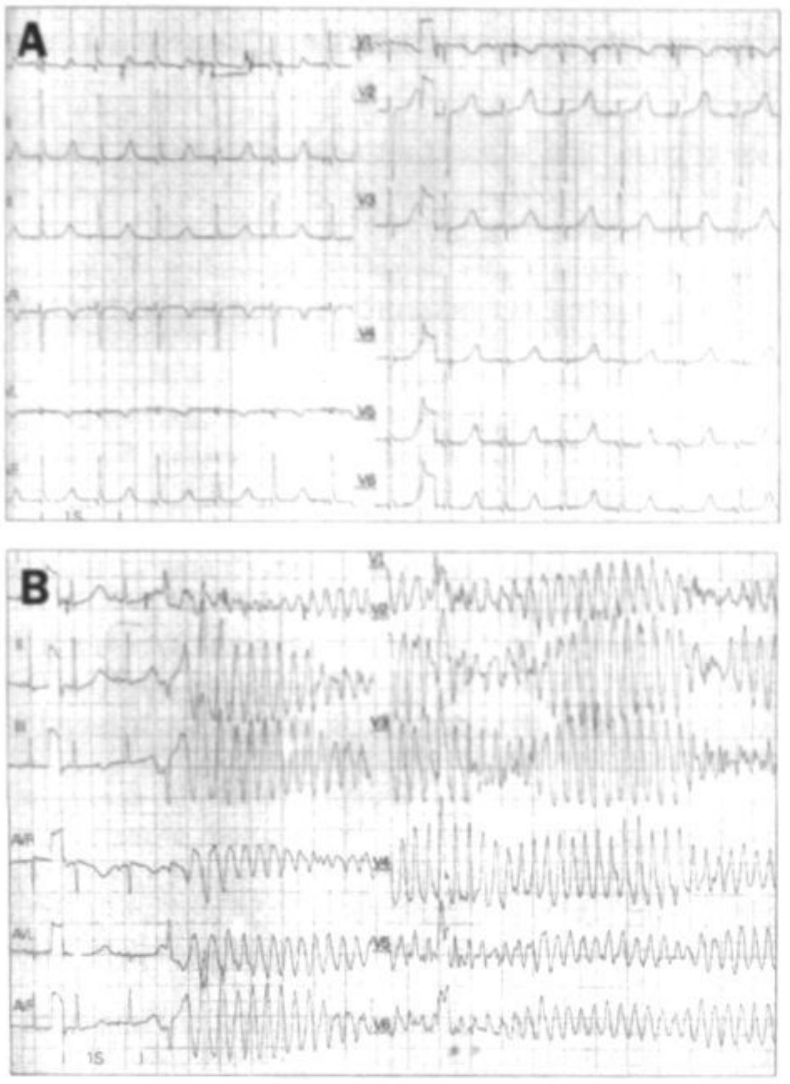

Figure 3. ECG recorded at rest (panel A) and during exercise (panel B) in a 10-year-old girl affected with LQTS, Tyr184Ser). The ECG in panel A shows an atrial rhythm, 82 beats per minute, PR interval $100 \mathrm{msec}$, QRS duration $80 \mathrm{msec}$, heart axis $+60^{\circ}$, and a $\mathrm{QT}$ interval of $500 \mathrm{msec}$, when corrected using Bazzet's formula $\left(\mathrm{QTC}=\mathrm{QT} /(\mathrm{RR})^{2}\right) 585 \mathrm{msec}$. Panel B shows an ECG recorded in the same patient during exercise. An ectopic atrial heart beat is followed by two sinus beats. The heart frequency is 90 beats per minute. The QT interval is not measurable accurately, but appears prolonged. A polymophic ventricular tachyarrhythmia of the 'torsade de pointes' type is triggered by a premature complex with a coupling interval of $480 \mathrm{msec}$. Calibration and lead-switch artefacts are present in both panels. Paper speed was $25 \mathrm{~mm} / \mathrm{sec}$. On the vertical axis, $10 \mathrm{~mm}$ represents $1 \mathrm{mV}$.

\section{References}

1. Keating M, Atkinson D, Dunn C, Timothy K, Vincent GM, Leppert M. Linkage of a cardiac arrhythmia, the long QT syndrome, and the Harvey ras-1 gene. Science. 1991:252:704-706.

2. Curran ME, Splawski I, Timothy KW, Vincent GM, Green ED, Keating MT. A molecular basis for cardiac arrhythmia: HERG mutations cause long QT syndrome. Cell. 1995:80:795-803.

3. Wang Q, Shen J, Splawski I, Atkinson D, Li Zhizhong, Robinson JL, Moss AJ, Towbin JA, Keating MT. SCN5A mutations associated with an inherited cardiac arrhythmia, long QT syndrome. Cell. 1995:80:805-811. 
4. Schott JJ, Charpentier F, Peltier S, Foley P, Drouin E, Bouhour JB, Donneley P, Vergnaud G, Bachner L, Moisan JP, Le Marec H, Pascal O. Mapping of a gene for long QT syndrome to chromosome 4q25-27. Am J Hum Genet. 1995:57:1114-1122.

5. Wang Q, Curran ME, Splawski I, Burn TC, Millholland JM, VanRaay TJ, Shen J, Timothy KW, Vincent GM, de Jager T, Schwartz PJ, Towbin JA, Moss AJ, Atkinson DL, Landes GM, Connors TD, Keating MT. Positional cloning of a novel potassium channel gene: KVLQT1 mutations cause cardiac arrhythmias. Nature Genet. 1996:12:17-23.

6. Splawski I, Tristani-Firouzi M, Lehrmann MH, Sanguinetti M, Keating MT. Mutations in the hminK cause long QT syndrome and suppress Iks function. Nature Genetics. 1997:17:338-340.

7. Kass RS, Davies MP. The roles of ion channels in an inherited heart disease: molecular genetics of the long QT syndrome. Cardiovasc Res. 1996:32:443-454.

8. Roden DM, Lazzara R, Rosen M, Schwartz PJ, Towbin J, Vincent GM. Multiple mechanisms in the long-QT syndrome. Current knowledge, gaps, and future directions. The SADS Foundation Task Force on LQTS. Circulation. 1996:8:1996-2012.

9. Moss AJ, Zareba W, Benhorin J, Locati EH, Hall WJ, Robinson JL, Schwartz PJ, Towbin JA, Vincent GM, Lehmann $\mathrm{MH}$. ECG T-wave patterns in genetically distinct forms of the hereditary long QT syndrome. Circulation. 1995:92:2929-2934.

10. Schulze-Bahr E, Haverkamp W, Breithardt G, Funke H, Wiebusch H, Assmann G. ECG repolarization patterns in chromosome 7-linked QT syndrome (LQTS 2). Circulation. 1996:94:2318-2319.

11. Schwartz PJ, Moss AJ, Priori SG, et al. Gene-specific influence on the triggers for cardiac arrest in the long QT syndrome [abstract]. Circulation. 1997:96:1-212.

12. Schwartz PJ, Priori SG, Locati EH, Napolitano C, Cantu F, Towbin JA, Keating MT, Hammoude H, Brown AM, Chen LS. Long QT syndrome patients with mutations of the SCN5A and HERG genes have differential responses to $\mathrm{Na}+$ channel blockade and to increases in heart rate. Implications for gene-specific therapy. Circulation. 1995:92:3381-3386.

13. Muellerbach R, Lagoda PJL, Welter C. An efficient salt-chloroform extraction of DNA from blood and tissues. Trends in Genetics. 1989:5:391.

14. Wilde AA, Jongbloed RJ, Doevendans PA, Duren DR, Hauer RN, van Langen IM, van Tintelen JP, Smeets HJ, Meyer H, Geelen Jl. Auditory stimuli as a trigger for arrhythmic events differentiate HERG-related (LQTS2) patients from KVLQT1-related patients (LQTS1). I Am Coll Cardiol. 1999:33:327-332.

15. Zareba W, Moss AJ, Schwartz PJ, Vincent GM, Robinson JL, Priori SG, Benhorin J, Locati EH, Towbin JA, Keating MT, Lehmann MH, Hall WJ. Influence of genotype on the clinical course of the long-QT syndrome. International Long-QT Syndrome Registry Research Group. N Engl J Med. 1998:339:960-965.

16. Priori SG, Napolitano C, Cantu F, Brown AM, Schwartz PJ. Differential response to Na+ channel blockade, beta-adrenergic stimulation, and rapid pacing in a cellular model mimicking the SCN5A and HERG defects present in the long-QT syndrome. Circ Res. 1996:78:1009-1015. 


\section{EFFECT OF MEDICAL TREATMENT IN GENOTYPED LQTS PATIENTS}

Gender differences in the long QT syndrome: effects of $B$-adrenoceptor blockade.

C.E. Conrath, MD, A.A.M. Wilde, MD, R.J.E. Jongbloed, M. Alders, PhD, I.M. van Langen, MD, J.P. van Tintelen, MD, P.A.F.M. Doevendans, MD, T. Opthof, PhD.

Cardiovascular Research 53: 770-776 (2002) 
Abstract.

Background: Gender differences have been reported in patients with the congenital long QT syndrome (LQTS). We analyzed whether electrocardiographic differences existed in females, males, girls and boys in response to $\beta$-adrenoceptor blockade.

Methods: 12 -lead ECGs before and during $\beta$-adrenoceptor blockade were collected in 87 genotyped LQTS patients ( 48 women, 14 men, 12 girls and 13 boys). Per ECG, up to three QTc intervals were determined in each lead. Difference between longest and shortest QT interval was taken as a measure for dispersion. V4 was used for further analysis. Results: 1) Adult males had the largest shortening of QTc interval upon treatment. During treatment adult males with LQTS, were found to have shorter QTC intervals than adult females, whereas this difference did not exist in LQTS ${ }_{2}$ patients. 2) Female LQTS 2 patients had a 50\% larger dispersion than female LQTS ${ }_{1}$ patients both before and during treatment. 3 ) In adult females a combination of a long QTc interval and large dispersion was found to be related to occurrence of symptoms, and sustentation of symptoms during treatment. 4) Adult male LQTS, patients constitute the only patient group with a marked decrease in both QTc interval and dispersion associated with a $100 \%$ efficacy of treatment in response to $\beta$-adrenoceptor blockade. Conclusions: These findings indicate that in addition to underlying differences in repolarization between men an women, also response to $\beta$-adrenoceptor blockade is modulated by gender-related factors.

Keywords: Adrenergic (ant)agonists; ECG; Gender; Long QT syndrome; QT dispersion

\section{Introduction}

The QT interval is known to be influenced by gender [1-3]. Young boys and girls have similar QT interval durations. During puberty, the QT interval in boys shortens, leaving adult women with a longer $\mathrm{QT}$ interval than adult men [2]. In the congenital Long QT Syndrome (LQTS) adult women have longer QT intervals than adult men $[4,5]$. Therefore they are more often clinically affected by this syndrome than men, in spite of the equal sex-distribution of the disease genotype. This is not restricted to electrocardiographic parameters. Female gender is an important risk factor for cardiac events in patients with this syndrome [6]. Furthermore, there is a different timedependent distribution of initial cardiac events $[4,7]$. In males, the probability of a first cardiac by age 15 , is higher than in females, and decreases after puberty, which it does not in females [7]. However, the first cardiac event is more often fatal in males than in females [7]. Thus, gender is a major determinant in the course and clinical presentation of patients with the Long QT Syndrome.

Women are more at risk than men of developing arrhythmias in response to QT prolonging drugs than men as well [8-10]. However, it is unknown whether there are 
differences in electrocardiographic response to purely $\beta$-adrenergic blocking agents between male and female carriers of long QT mutations. We have analyzed a genotyped population for sex linked differences in response to $\beta$-adrenoceptor blockade, with a distinction between adults and children. In addition, we analyzed whether these differences were specific for patients with mutations in the KCNQ1 gene (LQTS1) or the HERG gene (LQTS2), leading to changes in $I_{\mathrm{ks}}$ and $\mathrm{I}_{\mathrm{k}}$ current, respectively.

We found that during treatment with $\beta$-adrenoceptor blockade, men with LQTS, have shorter QTc intervals than women; this was not seen in LQTS, patients. Furthermore, female LQTS$_{2}$ patients showed more dispersion than female LQTS patients. No difference in the genetic subgroups was found among adult males. Patients remaining symptomatic during treatment showed a positive relation between the amount of dispersion and the duration of the QTC interval, in line with basic concepts of arrhythmogenesis.

\section{Methods}

The study was performed according to a protocol approved by the local ethics committees in the academic hospitals of Utrecht, Amsterdam and Maastricht, and conforms with the principles outlined in the Declaration of Helsinki (11). Written informed consent had been obtained in all patients. All genotyped LQTS and LQTS $_{2}$ patients in whom no more than one mutation had been found and who were treated with $\beta$-adrenoceptor blockade were included iı this study.

\section{Genotype analysis}

Patients were genotyped as previously described [12]. Briefly, genomic DNA was isolated from anticoagulated blood samples. Exons, encoding the complete sequence of the KCNQ1 and HERG $\left(\mathrm{KCNH}_{2}\right)$ gene, were amplified by using PCR analysis (Perkin Elmer 9700 thermal cycler). Subsequently, amplicons were analyzed by SSCP analysis. Gels were run at 5 and $15^{\circ} \mathrm{C}$, silver stained and air-dried. DNA fragments showing aberrant bands were purified (Qiagen PCR purification kit), sequenced by using the BigDye cycle sequencing kit (Applied Biosystems) and analyzed on an ABI-377 automatic sequencer (Applied Biosystems). In this study mutations were classified in both the gene involved (KCNQ1 or $K C \mathrm{NH}_{2}$ ) and the effect of the mutation i.e. mutations leading to a stop-codon or a frameshift (truncating) and mutations leading to an amino acid substitution (missense). Three kinds of mutations were identified, i.e. LQTS $_{1} /$ missense (11 mutations), LQTS $/$ /truncating ( 6 mutations) and LQTS $/$ /missense (9 mutations). 


\section{Electrocardiography}

In 12-lead ECGs before and during treatment up to three consecutive RR and QTintervals were measured in all leads. QTc intervals were calculated using Bazett's formula ( $\mathrm{QTC}=\mathrm{QT} / \mathrm{VRR}$ ). All intervals were measured manually. The intersection of the line through steepest part of the downslope of the T-wave and the isoelectric line was defined the end of the $T$-wave. The end of the $U$ wave was used in case fusion of $T$ and $U$ waves made distinction of the end of the T-wave impossible. In a minority of cases (mostly concerning the right precordial leads) the highest point of the second part of a biphasic T-wave was determined the end of the T-wave, based on T-wave morphology in subsequent leads. QT intervals were always determined similarly on the ECG before and the ECG during treatment in one patient. The difference between the longest and the shortest QT interval in any lead was used as a measure for dispersion.

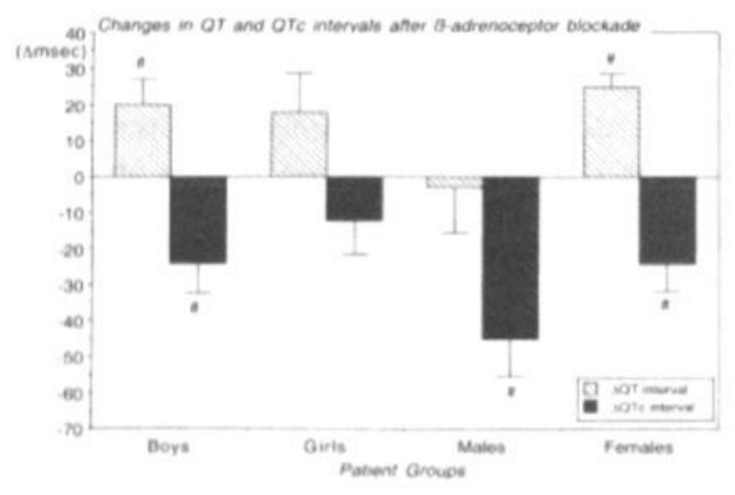

Figure 1. Changes in $\mathrm{QT}$ and QTc intervals during $\beta$-adrenoceptor blockade are shown in boys, girls, males and females. \#, Statistically significant change. In QT intervals this change was $20 \pm 7.2(P<0.02)$, $18 \pm 10.7$ (NS), $-3 \pm 12.4$ (NS), and $25 \pm 6.7$ ( $P$ $<0.001)$ in the four groups, respectively. The difference between males and females was statistically significant (ANOVA; $P<0.05$ ). Changes in QTC were $-24 \pm 8.4(P<0.02)$, $12 \pm 9.3$ (NS), $-45 \pm 10.3(P<0.001)$ and $-24 \pm 7.5$ $(P<0.01)$, respectively.

\section{Symptomatology}

Symptomatology before and during treatment was determined. Patients who presented with cardiac arrest, registered torsades de pointes, a history of syncope, or, during treatment, pre-syncope that required alteration in their medication were defined as symptomatic. Follow-up during treatment was $5.5 \pm 5.7$ years (average \pm S.D.). Three patient categories were defined based on clinical presentation: symptomatic before treatment and symptomatic during treatment (S-S), symptomatic before treatment and asymptomatic during treatment (S-A) and asymptomatic before and during treatment (A-A).

\section{Statistical analysis}

Differences between variances among the groups of boys, girls, males and females were tested by the $F$-test. In case of similarity of variances this was followed by oneway ANOVA before and during treatment. Changes in QT or QTc intervals following treatment were analyzed by the Student's $t$-test for paired observations to test differences from zero. Differences between changes in QT or QTC intervals between 
boys, girls, males and females were tested by one-way ANOVA. Values are given as mean \pm SEM. Levels of 0.05 or less were considered statistically significant.

\section{Results}

Change in $\mathrm{QT}$ and $\mathrm{QT}(\mathrm{c})$ intervals by $\beta$-adrenoceptor blockade in females, males, girls and boys

A total of 87 patients was included in this study: 48 women, 14 men, 12 girls and 13 boys (1-15 years). Fig. 1 shows that in boys $(P<0.02)$ and females $(P<0.001)$ QT intervals increased upon $\beta$-adrenoceptor blockade. Such an increase was not observed in males, whereas there was an insignificant increase in girls. Moreover, the difference between males and females was significant (ANOVA; $P<0.05$ ). Because RR intervals increased even more than QT intervals, QTc intervals decreased $\beta$-adrenoceptor blockade (Figure 1). This decrease varied from $12 \pm 9.3$ (NS) in girls to a largest value of $45 \pm 10.3$ in males $(P<0.001)$.

\section{QTc intervals in men, women and children with LQTS, and LQTS,}

QTc intervals were similar in all groups (Figure 2A). During treatment, adult males had significantly shorter QTC intervals than adult females in LQTS, but not in LQTS patients (Figure 2B; Table 1). Both males and females showed shortening of the QTC interval during treatment (compare Figure $2 \mathrm{~A}$ and $\mathrm{B}$ ). No differences in response to $\beta$ adrenoceptor blockade existed between LQTS Lnd LTS $_{2}$ in the four subgroups. In adult LQTS 1 males shortening of the QTc interval upon treatment was $49 \pm 13.1 \mathrm{~ms}$. In adult males with LQTS 2 the QTc interval decreased $42 \pm 15.9$ ms during treatment. In both groups shortening was statistically significant $(P<0.02$ and $P<0.05$, respectively). Women with LQTS $_{1}$ had a shortening of $37 \pm 16.7 \mathrm{~ms}$, and those with LQTS 2 of $19 \pm 8.2$ $\mathrm{ms}$, which was in both groups significantly different from zero $(P<0.05)$. In children the changes in QTc interval were less pronounced (compare Figure $2 \mathrm{~A}$ and $\mathrm{B}$ ).

\section{Gender differences in dispersion}

In women dispersion differed significantly between LQTS and $_{1}$ LQTS 2 patients (Figure 3). In men however, the two genetic groups did not differ. Dispersion in females was $41 \pm 6.2 \mathrm{~ms}$ in the LQTS ${ }_{1}$ group and $62 \pm 3.7 \mathrm{~ms}$ in the LQTS 2 group $(P<0.01)$. Ithe difference in dispersion between adult female LQTS L $_{1}$ and LQTS 2 patients was also observed when girls were included in the female group. The larger dispersion in female $\mathrm{LQTS}_{2}$ patients proved to be independent of age (linear regression analysis; data not shown). 


\section{Symptomatology}

Table 2 shows the efficacy of treatment in the LQTS ${ }_{1}$ and LQTS 2 patient groups divided into boys, girls, males and females. Efficacy was defined as the percentage of S-A patients within the $(S-A+S-S)$ groups. Of course, the numbers are very small in most of the subgroups. In adults, the efficacy of treatment was $100 \%$ in male and $89 \%$ in female LQTS, patients. In adult LQTS, patients, efficacy of treatment was $67 \%$ in males and $70 \%$ in females.

(A)

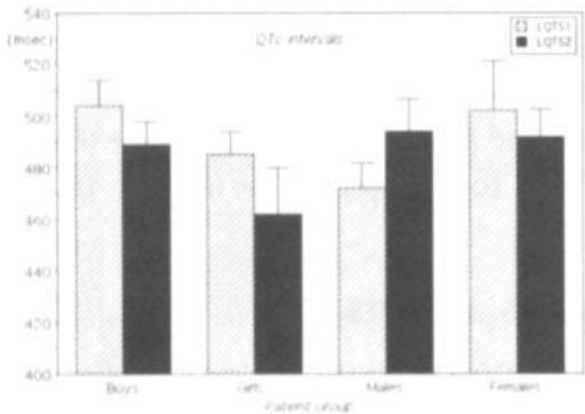

(B)

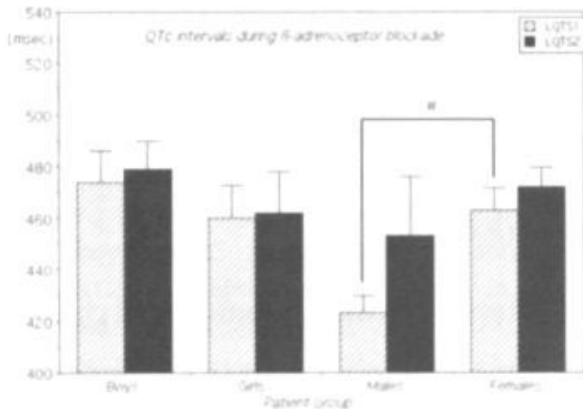

Figure 2. QTc intervals in boys, girls, males and females with LQTS and LQTS, are plotted before (A) and during (B) $\beta$-adrenoceptor blockade. See Table 1 for numerical data. Before treatment, QTc intervals were similar in all groups. During treatment, significantly shorter QTc intervals were found in male than in female LQTS, patients, while no such difference was seen in LQTS, patients. \#, Statistical significance at $P<0.01$.

Table 1. QTc intervals in females, males, girls, and boys with LQTS1 and LQTS2

\begin{tabular}{|c|c|c|c|c|c|c|}
\hline & & \multirow[t]{2}{*}{ n } & \multicolumn{2}{|c|}{ Before treatment } & \multicolumn{2}{|c|}{ During treatment } \\
\hline & & & QTC & dispersion & QTC & dispersion \\
\hline females & $\begin{array}{l}\text { LQTS, } \\
\text { LQTS, }\end{array}$ & $\begin{array}{l}13 \\
35\end{array}$ & $\begin{array}{l}502 \pm 19.3 \\
491 \pm 10.5\end{array}$ & $\begin{array}{l}41 \pm 6.2^{\circ} \\
62 \pm 3.7^{\circ} \\
p<0.01\end{array}$ & $\begin{array}{l}463 \pm 8.5 \\
472 \pm 7.6\end{array}$ & $\begin{array}{l}40 \pm 5.3^{\circ} \\
63 \pm 4.4^{\circ} \\
p<0.005\end{array}$ \\
\hline males & $\begin{array}{l}\text { LQTS, } \\
\text { LQTS, }\end{array}$ & $\begin{array}{l}6 \\
8\end{array}$ & $\begin{array}{l}472 \pm 9.9 \\
494 \pm 12.5\end{array}$ & $\begin{array}{l}56 \pm 10.5 \\
53 \pm 9.5\end{array}$ & $\begin{array}{l}422 \pm 9.1 \\
449 \pm 15.4\end{array}$ & $\begin{array}{l}47 \pm 7.8 ? \\
50 \pm 6.9\end{array}$ \\
\hline girls & $\begin{array}{l}\text { LQTS }_{1} \\
\text { LQTS }_{2}\end{array}$ & $\begin{array}{l}6 \\
6\end{array}$ & $\begin{array}{l}485 \pm 9.1 \\
462 \pm 17.9\end{array}$ & $\begin{array}{l}49 \pm 7.6 \\
62 \pm 3.6\end{array}$ & $\begin{array}{l}460 \pm 2.7 \\
462 \pm 16.0\end{array}$ & $\begin{array}{l}38 \pm 6.4^{\circ} \\
64 \pm 7.6^{\circ} \\
P<0.05\end{array}$ \\
\hline boys & $\begin{array}{l}\text { LQTS, } \\
\text { LQTS, }\end{array}$ & $\begin{array}{l}9 \\
4\end{array}$ & $\begin{array}{l}504 \pm 10.4 \\
489 \pm 8.8\end{array}$ & $\begin{array}{l}50 \pm 7.8 \\
66 \pm 16.9\end{array}$ & $\begin{array}{l}474 \pm 12.0 \\
479 \pm 10.8\end{array}$ & $\begin{array}{l}50 \pm 5.6 \\
56 \pm 3.9\end{array}$ \\
\hline
\end{tabular}

\section{Symptomatology, QTc intervals and dispersion}

A positive relationship existed between the length of the QTC interval and the amount of dispersion in the adult S-S patients (seven women, one man) (Figure 4). In addition, in this figure the type of LQTS is stated as well as the type of the mutation. Patients 
with a truncating $\mathrm{LQTS}_{2}$ mutation had the shortest QTc intervals and the least dispersion. Patients with missense mutations had larger dispersion and a longer QTc interval, and the only LQTS, patient that remained symptomatic during treatment also had an extremely long QTc interval and a large dispersion (655 and $100 \mathrm{~ms}$, respectively before treatment (see Figure 4) and still 513 and 73 ms during treatment). During treatment QTc intervals were shorter and dispersion was smaller in the four groups with the highest efficacy of treatment (89-100\%) compared with the other four groups with lower efficacy (50-70\%) (Figure 5). In male LQTS, patients both reduction in dispersion were the largest compared to all other patient groups.

\section{Discussion}

Patients with the congenital Long QT Syndrome demonstrate electrocardiographic differences during treatment with $\beta$-adrenoceptor blockade between adult males, females, and children (Figures 1 and 2). Although no differences exist in QTc intervals before treatment among these groups, during treatment adult men in the LQTS group $_{1}$

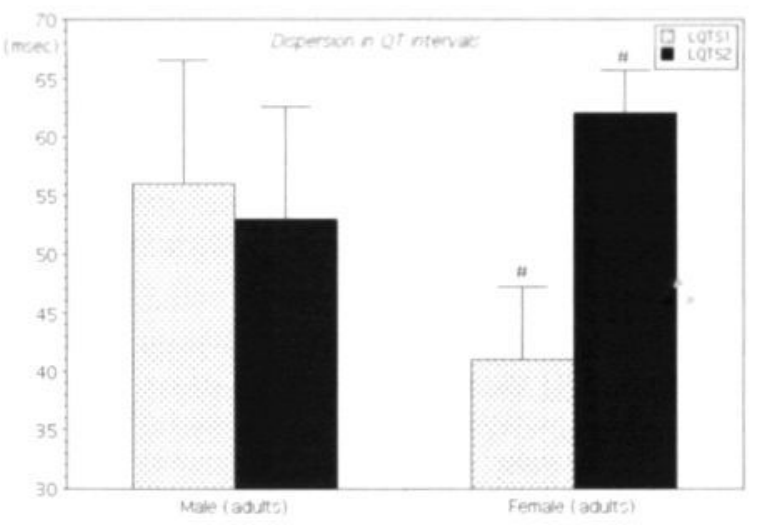

Figure 3. Dispersion in QT intervals is shown in males and females before treatment. In women, LQTS 2 patients have significantly more dispersion than LQTS, patients, whereas in men no difference is found between LQTS, and LQTS 2 patients. See Table1 for numerical data.

display the shortest QTC intervals (Figure 2B). Woman with LQTS 2 , have a significantly larger dispersion than women with LQTS, both before (Figure 3, Table 1) and during treatment (Table 1). In addition in women that remained symptomatic during treatment, LQTS 2 patients with a missense mutation had longer QTc intervals combined with a larger dispersion than those with a truncating mutation (Figure 4). In patient groups with highest efficacy of treatment, QTc intervals were shorter and dispersion was smaller during $\beta$-adrenoceptor blockade (Figure 5 ). This study is the first to show gender differences in electrocardiographic response to $\beta$-adrenoceptor blockade in LQTS patients. 


\section{QTc intervals in females, males, girls and boys}

Differences in cardiac repolarization between men and women have been reported in healthy subjects and in LQTS patients $[1-5,7]$. Healthy women have longer QTC intervals and a higher heart rate. Stramba-Badiale et al [3] showed QT differences to be more profound during low heart rates due to a steeper QT/RR relationship in women than in men. Also in the Long QT Syndrome women and children were reported to have longer QTc intervals than men $[4,5]$, while female gender has been shown to be an independent risk factor for cardiac events.

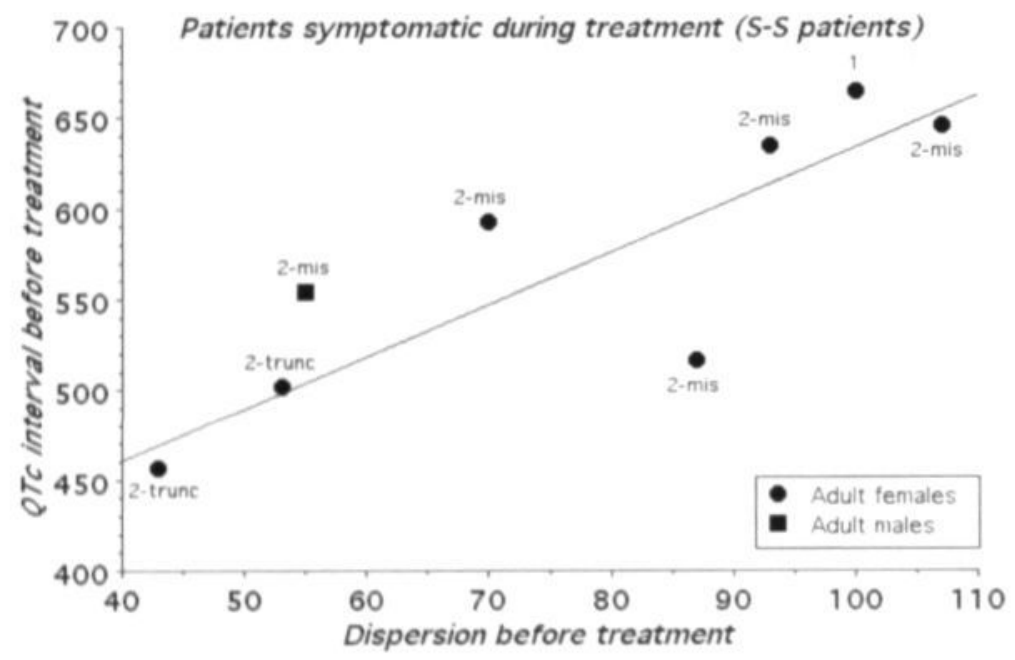

Figure 4. Patients symptomatic during treatment show a positive relationship between the length of the QTc interval and amount of dispersion. 1, LQTS , 2, LQTS $;$; Mis, missense mutation; trunc, truncating mutation. As indicated, LQTS , patients with a truncating mutation have a relatively short QTc intervals and little dispersion. LQTS, patients with missense mutations had a longer QTc interval and larger dispersion, as had the only (female) LQTS, patient that remained symptomatic during treatment.

Table 2. Efficacy of treatment in females, males, girls, adn boys with LQTS, and LQTS,

\begin{tabular}{lcccc}
\hline \multirow{3}{*}{ Females } & A-A & S-A & S-S \\
& LQTS1 & 4 & 8 & 1 \\
\multirow{3}{*}{ Gales } & LQTS2 & 15 & 14 & 6 \\
& LQTS1 & 3 & 3 & 0 \\
\multirow{3}{*}{ Boys } & LQTS2 & 3 & 2 & 1 \\
& LQTS1 & 3 & 3 & 0 \\
& LQTS2 & 4 & 1 & 1 \\
& & & & 1 \\
\end{tabular}


To be able to understand differences in response to treatment in male and female subjects, it is necessary to understand the physiological background of gender differences in cardiac repolarization. Unfortunately, little is known about the influence of sex hormones on cardiac repolarization. In humans, androgens may shorten the QTC interval $[2,4,5])$, whereas the effect of estrogens in humans is equivocal. Most studies addressing this issue have been performed in castrated rabbits treated with either estrogen or dihydrotestosteron (DHT). Pham et al [13] showed that the duration of the first $30 \%$ of the action potential (APD30) was significantly shorter in castrated males than in castrated females, indicating a hormone-independent factor in differences in cardiac repolarization. An increase in QT interval was found in oophorectomized rabbits treated with estrogens compared to DHT, especially at long cycle lengths, due to a steeper QT/RR relationship [14]. In contrast, Drici et al [15] found a lengthening of the QT interval in explanted hearts both from animals treated with male and from those treated with female sex hormones. In addition, they found a downregulation of the HK2 (human Kv1.5 [(16] and IsK (minK, a subunit to KCNQ1 that encodes the protein associated to $\mathrm{I}_{\mathrm{ks}}[17]$ in both groups. The similar $\mathrm{QT}$ intervals in this study are not in conflict with other studies as QT intervals were measured at a short cycle length, while differences in QT interval are more pronounced at long cycle length. Besides a lower $I_{k_{1}}$, Liu et al [18] identified a lower $I_{k r}$ current density in female than in male rabbits, which they held responsible for the steeper QT/RR relationship in female animals These studies might form a rationale for the occurrence of longer QTC intervals in females. In our population, men and women had similar QTc intervals before treatment. This can be explained by the fact that we only studied treated carriers. Upon treatment with $\beta$-adrenoceptor blockade, males had a greater shortening of the QTC interval than females. This was due to a shorter QTc during treatment in male than in female LQTS, patients. This difference was not found in $\mathrm{LQTS}_{2}$ patients. Figure $2 \mathrm{~A}$ shows that before treatment women with LQTS ${ }_{1}$ had slightly larger QTc intervals than men. If findings in rabbits [18] hold true for the human species as well, this could be due to less $I_{k}$ in the female ventricle.

\section{Gender differences in dispersion}

We recently reported that LQTS 2 patients in general display larger dispersion than LQTS, patients [19]. However, no differences in dispersion were found between males with LQTS ${ }_{1}$ and LQTS, whereas women with LQTS ${ }_{2}$ had significantly larger dispersion than those with LQTS. A decrease of homogeneously distributed repolarizing $I_{K_{1}}$ current may uncover a larger inhomogeneous contribution of $\mathrm{I}_{\mathrm{Ks}}[20]$ to repolarization in LQTS ${ }_{2}$ patients, and thus lead to larger dispersion of action potential duration over the ventricular wall. Our data suggest that the inhomogeneous transmural distribution of $\mathrm{I}_{\mathrm{ks}}$ is larger in females than in males. This is supported by the fact that QT/RR relationship is steeper in women than in men [5], which might be due to more 
$I_{\mathrm{ks}}$ in the latter. To our knowledge there are no experimental data available to settle this issue. However, the fact that this difference between female LQTS ${ }_{1}$ and LQTS $_{2}$ patients was similar in adult females and in girls and was independent of age excludes an important role for estrogens and suggests a hormone independent difference between the male and female heart.

In conclusion, gender differences exist in response to $\beta$-adrenoceptor blockade in patients with types 1 and 2 of the congenital long QT syndrome. During treatment males with LQTS1 have shorter QTc intervals than females and adult patients with LQTS2. Also treated females with LQTS $_{1}$ exhibited less dispersion than those with LQTS $_{2}$. Furthermore, an association was identified between efficacy of treatment and the relationship between QTC interval and dispersion. Studies to elucidate the underlying mechanisms of gender differences in response to $\beta$-adrenoceptor blockade will be needed to settle these issues.

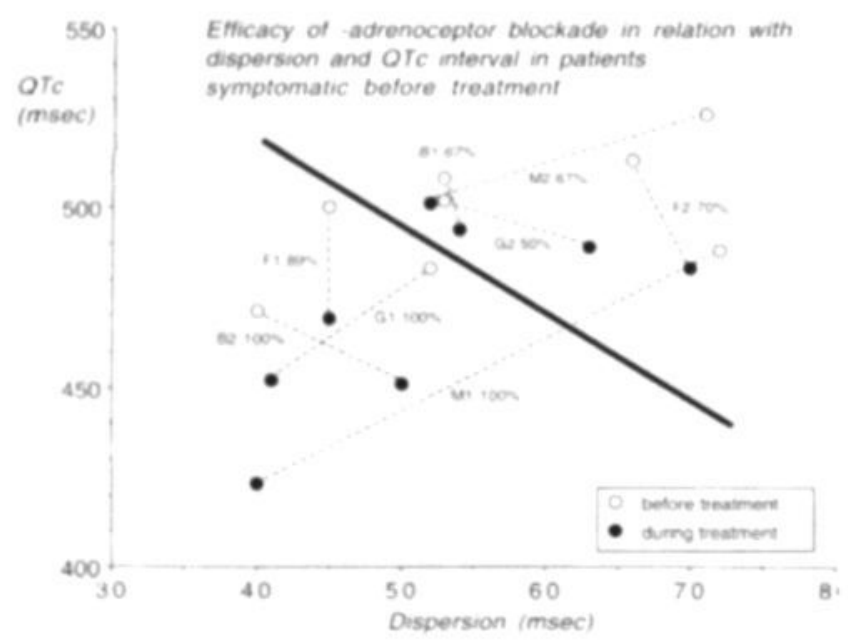

Figure 5 . Efficacy of treatment, (S-A/(S-A+(S-S)) 100 , is shown in the 4 groups subdivided into LQTS, and $\mathrm{LQTS}_{2}$, in relation to the average QTc interval and the average dispersion for these patients in each group. $B$ indicates boys, $G$ girls, $M$ males and $F$ females. 1 and 2 indicate LQTS, and LQTS, Pre $=$ before treatment, post= during treatment. The percentage represents the efficacy of treatment in each group (compare Figure 5). Shorter QTc intervals, less dispersion or a combination of both were related to a larger efficacy. In LQTS, males, absence of symptoms during treatment was associated with a reduction in both dispersion and QTc duration. Efficacy of treatment tends to be larger in adult LQTS, patients than in adult LQTS, patients.

Acknowledgements. We wish to thank G.C.M. Beaufort-Krol, MD, M.Th.E. Bink-Boelkens, MD, and M.P. van den Berg, MD, University Hospital Groningen, Groningen, L. Lubbers, MD, Academic Medical Center, Amsterdam, R.F. Veldkamp, MD, Medical Center Haaglanden, The Hague, F.A.L.E. Bracke, MD, Catherina Hospital, Eindhoven, M. Witsenburg, MD, Sophia Children Hospital, Rotterdam, and T.M. Hoorntje, MD, R.N.W. Hauer, MD, and E.O. Robles de Medina, MD, from the Department of Cardiology, 
University Medical Center, Utrecht for contributing patient data. This study was made possible by a grant of the Netherlands Heart Foundation (no. 95.014), and the Interuniversitary Cardiology Institute of the Netherlands (ICIN, project no. 27)

\section{References}

1. Merri M, Benhorin J, Alberti M, Locati E, Moss A. Electrocardiographic quantitation of ventricular repolarization. Circulation 1989;80:1301-308.

2. Rautaharju PM, Zhou SH, Wong S, et al. Sex differences in the evolution of the electrocardiographic QT interval with age. Can J Cardiol 1992;8:690-95.

3. Stramba-Badiale M, Locati EH, Martinelli A, Courville J, Schwartz PJ. Gender and the relationship between ventricular repolarization and cardiac cycle length during $24-\mathrm{h}$ Holter recordings. Eur Heart J 1997; 18:1000-1006.

4. Hashiba K. Sex differences in phenotypic manifestations and gene transmission in the Roman-Ward syndrome. Ann NY Acad Sci 1992;644:142-156.

5. Lehmann $\mathrm{MH}$, Timothy KW, Frankovich D, et al. Age-gender influence on the rate-corrected QT interval and the QT-heart rate relation in families with genotypically characterized long QT syndrome. J Am Coll Cardiol 1997;29:93-99.

6. Moss AJ, Schwartz PJ, Crampton RS, et al. The long QT syndrome. Prospective longitudinal study of 328 families. Circulation 1991;84:1136-1144.

7. Locati EH, Zareba W, Moss AV, et al. Age- and sex-related differences in clinical manifestations in patients with congenital long-QT syndrome: findings from the International LQTS Registry. Circulation 1998;97:2237-2244.

8. Makkar RR, Fromm BS, Steinman RT, Meissner MD, Lehmann MH. Female gender as a risk factor for torsades de pointes associated with cardiovascular drugs. Jama 1993;270:2590-597.

9. Lehrmann $M H$, Hardy S, Archibald D, quart B, MacNeil DJ. Sex difference in risk of torsade de pointes with d,I-sotalol. Circulation 1996;94:2535-2541.

10. Pratt CM, Camm AJ, Cooper W, et al. Mortality in the Survival With ORal D-sotalol (SWORD) trial: why did patients die? Am J Cardiol 1998;81:869-876.

11. World Medical Association Declaration of Helsinki. Recommendations guiding physicians in biochemical research involving human subjects. Cardiovasc Res 1997:35:2-3.

12. Wilde AA, Jongbloed RJ, Doevendans PA, et al. Auditory stimuli as a trigger for arrhythmic events differentiate HERG-related (LQTS2) patients from KVLQT1-related patients (LQTS1). J Am Coll Cardiol 1999;33:327-332.

13. Pham TV, Sosunov EA, Gainullin RZ, Danilo P, Jr., Rosen MR. Impact of sex and gonadal steroids on prolongation of ventricular repolarization and arrhythmias induced by $i(k)$-blocking drugs. Circulation 2001;103:2207-2212.

14. Hara M, Danilo P, Jr., Rosen MR. Effects of gonadal steroids on ventricular repolarization and on the response to E4031. J Pharmacol Exp Ther 1998;285:1068-1072.

15. Drici MD, Burklow TR, Haridasse V, Glazer RI, Woosley RL. Sex hormones prolong the QT interval and downregulate potassium channel expression in the rabbit heart. Circulation 1996;94:1471-1474.

16. Snyders DJ, Tamkun MM, Bennett PB. A rapidly activating and slowly inactivating potassium channel cloned from human heart. Functional analysis after stable mammalian cell culture expression. J Gen Physiol 1993;101:513-543.

17. Sanguinetti MC, Curran ME, Zou A, et al. Coassembly of K(V)LQT1 and minK (IsK) proteins to form cardiac I(Ks) potassium channel. Nature 1996;384:80-83.

18. Liu XK, Katchman A, Drici MD, et al. Gender difference in the cycle length-dependent QT and potassium currents in rabbits. J Pharmacol Exp Ther 1998;285:672-679. 
19. Conrath CE, Opthof T, van Langen IM. Differences in response to B-adrenergic blockade in LQTS1 and LQTS2 patients. European Heart Journal 2001 (Abstr, Suppl.):607

20. Liu DW, Antzelevitch C, Characteristics of the delayed rectifier current $\left(I_{\mathrm{kr}}\right.$ and $\left.I_{\mathrm{ks}}\right)$ in canine ventricular epicardial, midmyocardial, and endocardial myocytes. A weaker $I_{\mathrm{ks}}$ contributes to the longer action potential of the M cell. Circ Res 1995:76:351-365. 


\section{FAMILIAL HYPERTROPHIC CARDIOMYOPATHY}

\section{Hypertrophic Cardiomyopathy}

Lucie Carrier ${ }^{1}$, Roselie Jongbloed ${ }^{2}$, Bert Smeets ${ }^{2}$, Pieter A. Doevendans ${ }^{3}$

Cardiovascular Genetics for Clinicians, 239:139-154 (2001). Kluwer Academic Publishers (Dordrecht) eds. P.A. Doevendans and A.A.M. Wilde. 


\section{HYPERTROPHIC CARDIOMYOPATHY}

\subsection{Introduction}

Up till a decade ago, diagnostic identification of acquired or hereditary cardiac diseases was based upon clinical observations and pedigree analysis and supported by instrumental and biochemical diagnostic tests. The molecular basis of the majority of these disorders was grossly unknown or speculative. In the last ten years, rapidly evolving and innovative strategies in molecular biology and genetics have completely changed this scenario. Families with well-documented hereditary disorders, sometimes known for several decades, appeared very attractive to start the search for the causative molecular defect. Using linkage analysis with DNA markers (DNA variants scattered along the genome), it became possible to search for linkage of particular markers and the disease-causing locus in a given family. Once the risk locus was identified, several strategies to identify the gene defect could be applied. By comparing families with identical genetic defects and by an inventory on the clinical features of all affected individuals it may be possible to establish genotype-phenotype correlations, which in turn can lead to an exact diagnosis.

In this chapter we discuss clinical and genetic guidelines to identify the familial form of primary HCM. HCM includes a group of primary myocardial disorders of previously undefined etiology, which are characterized by a high incidence of morbidity and mortality. Observations of myocardial diseases that can reasonably be interpreted as $\mathrm{HCM}$ were made in the middle of the last century at the Hospital La Salpêtrière in Paris by $A$. Vulpian, who called what he saw at the macroscopic level a "retrecissement de l'orifice ventriculo-aortique" or " sub-aortic stricture " [1]. It was however only in the late 1950 s that the unique clinical features of HCM were systematically described [2, 3]. Hypertrophy can occur in either ventricle although usually there is involvement of the interventricular septum, with or without involvement of either the anterior wall or the posterior wall in continuity. A particular form of regional involvement affects the apex but spares the upper portion of the septum (apical hypertrophy) [4]. Typically, the left ventricular volume is normal or reduced. Systolic gradients are common. Typical morphological changes include myocyte hypertrophy and disarray surrounding the areas of increased loose connective tissue. Arrhythmias and premature sudden death are common [5]. Sudden death accounts for about $50 \%$ of the mortality in HCM. Sudden death may be the first clinical manifestation in some affected individuals. Previous reports estimated its incidence to 2 to $4 \%$ annually in adults and 4 to $6 \%$ in children and adolescents [6-8] but these numbers are certainly overestimated because they are based on referral populations. Annual mortality rate in unselected patients has been reported to be 0.5 to $1.5 \%$ [9]. 
$\mathrm{HCM}$ is the most common cause of sudden death in young athletes, accounting for $36 \%$ of cases. Although HCM has been regarded largely as a relatively uncommon cardiac disease, the prevalence of echocardiographically defined HCM in a large cohort of apparently healthy young adults selected from a community-based general population was reported three years ago to be as high as $0.2 \%$ [10].

\subsection{Familial Hypertrophic Cardiomyopathy (FHC)}

Familial disease with autosomal dominant inheritance predominates, and the first large pedigree of familial hypertrophic cardiomyopathy (FHC) was reported in 1960 [11]. None of the previous hypotheses on the pathophysiological mechanisms would have predicted that defects in sarcomeric genes could be a possible molecular basis for the disease. The results of molecular genetic studies have nevertheless shown that all mutations found thus far concern nine different sarcomeric proteins (figure 1, Table 1): three myofilament proteins, the beta-myosin heavy chain ( $\beta-M y H C)$, the ventricular myosin essential light chain (MLC-1s/v) and the ventricular myosin regulatory light chain (MLC-2s/v); four thin filament proteins, alpha cardiac actin (alpha-cAct), cardiac troponin T (cTnT), cardiac troponin I (cTnl), and alpha-tropomyosin (alpha-TM); one myosin-binding protein, the cardiac myosin binding protein C ( $\mathrm{CMyBP-C}$ ), and finally the third filament protein, titin (TTN).

So, $\mathrm{FHC}$ is caused by a structural and/or functional impairment of the sarcomere, which is the contractile unit of striated muscle (Figure 1). Sarcomeric gene mutations may also be associated to either the transition between hypertrophic and dilated cardiomyopathy [14] or to primary dilated cardiomyopathy $[15,16]$. This finding suggests that the position of the mutated amino acid triggers the development of either hypertrophic or dilated cardiomyopathy by impaired force generation versus impaired force transmission, respectively. The molecular mechanism by which the mutations lead to FHC and the basis for the diversity of the phenotypes is not completely elucidated. It has been generally accepted that cardiac hypertrophy is influenced by a dominantnegative mechanism, which can be explained by either production of a poison polypeptide or failing to incorporate a defective protein into the sarcomere leading to haploinsufficiency.

In 1999, 143 mutations have been entered in the FHC database (Table 2) [17] The two major genes appear to be $M Y H 7$ and $M Y B P C 3$, but one should note that not obligatory all the genes were screened to find the mutation in previous reports. Most of the FHC mutations are missense mutations or deletions that do not disrupt the reading frame with the exception of $M Y B P C 3$ in which most are frame shift mutations. 


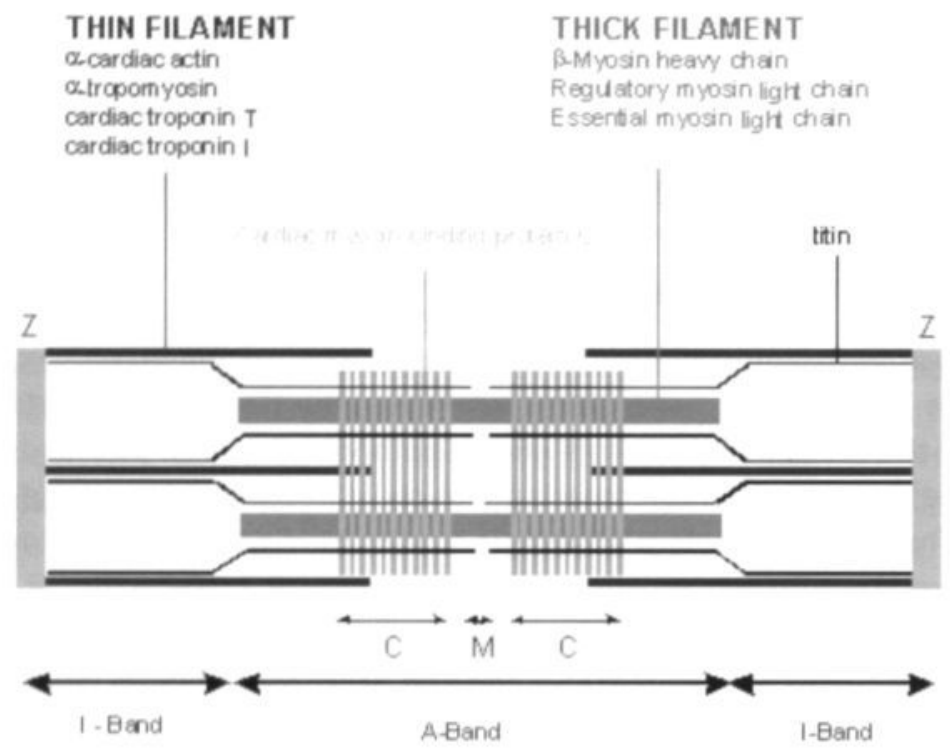

Figure 1. Schematic organization of the sarcomeric proteins associated with FHC (adapted from [18]). These genes certainly do not represent the whole spectrum of FHC disease genes since an additional locus was reported on chromosome $7 q[12]$ and one might reasonably hypothesize that disease genes yet to be identified include additional components of the sarcomere. Indeed, recently a mutation has been reported in $\mathrm{MYH}$, the strongly $\mathrm{MYH7}$ homologous gene encoding the $\alpha-\mathrm{MyHC}$ in a FHC proband [13].

\section{Mutations in the beta-MyHC gene, MYH7 (CMH1 locus)}

Jarcho et al. opened this field in 1989 by studying a large Canadian HCM family which had been previously reported by Pare et al. in 1961[19, 20]. Linkage analysis showed tight association of a disease locus with marker D14S26, and therefore identified the first locus for $\mathrm{FHC}, \mathrm{CMH}$. Among the possible candidate genes involved in $\mathrm{HCM}$, the closely linked cardiac $\alpha$ - and $\beta$-myosin heavy chain (MyHC) genes - MYH6 and MYH7, respectively were suspected. Subsequently, a missense mutation was found in the MYH7 gene [21]. Several other investigators have confirmed the linkage of HCM families to $\mathrm{CMH} 1[22,23]$. Likewise other groups excluded linkage of FHC families to $\mathrm{CMH} 1$ indicating genetic heterogeneity $[24,25]$. The beta-MyHC consists of 1,939 amino acids and is the major isoform in human ventricular cardiac myocytes and slow twitch skeletal muscles. It is composed of two parts, a globular amino-terminal part of $150 \mathrm{kDa}$, the heavy meromyosin ( $\mathrm{HMM})$ and the rod or tail of $70 \mathrm{kDa}$, the light meromyosin (LMM). HMM can be separated in two domains by papainne digestion, the subfragments 1 and 2 . Subfragment 2 contains the ATP- and actin-binding sites. More than seventy $\mathrm{MYH} 7$ mutations were identified and most of them are located in $\mathrm{HMM}$. 


\section{Table 1. Sarcomeric proteins and genes involved in FHC.}

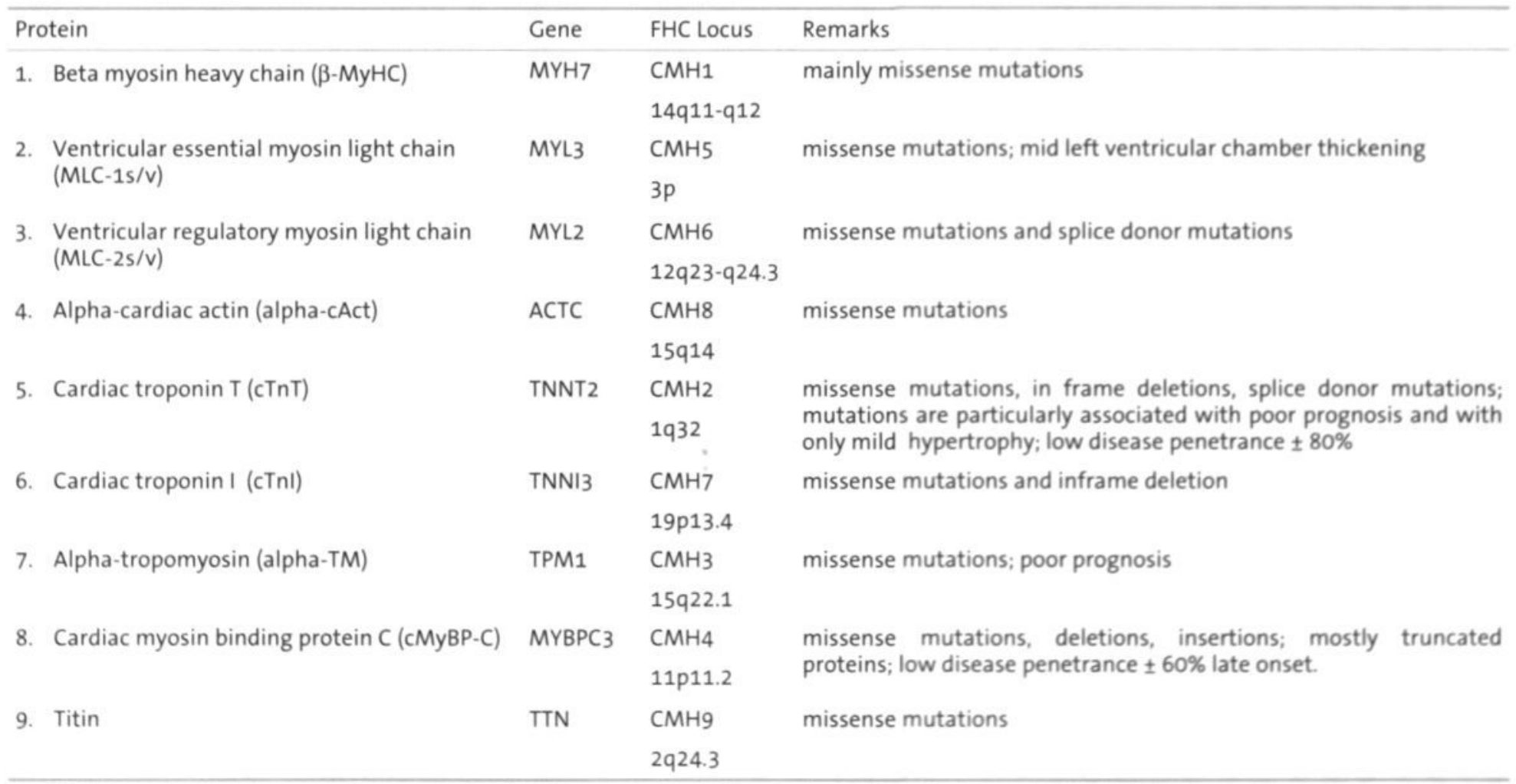




\section{Mutations in the myosin light chain genes, MYL2 and MYL3 (CMH5 \& CMH6 loci)}

The muscle myosin proteins consist of two heavy chains and two pairs of light chains. The isoforms of light chains expressed in human ventricles are the ventricular essential myosin light chain (MLC-1s/v) and ventricular regulatory myosin light chain (MLC$2 s / v)$. These two proteins are encoded by $M Y L 3$ and $M Y L 2$, which are located on chromosome $3 p$ and $12 q 23-q 24.3$, respectively [26]. Mutations in both genes were first described to be associated with a particular subtype of cardiac hypertrophy defined by mid left ventricular obstruction and skeletal myopathy [27]. However, it was later demonstrated that MYL2 is also associated with classical forms of FHC [28].

\section{Table 2. Distribution of the FHC database mutations (from [17])}

\begin{tabular}{lccc}
\hline Gene locus & \# of mutations & $\begin{array}{c}\text { \# of missense mutations or in frame } \\
\text { deletions }\end{array}$ & $\begin{array}{c}\text { \# of frameshift or nonsense } \\
\text { mutations }\end{array}$ \\
\hline MYH7 & 70 & 67 & 3 \\
MYBPC3 & 30 & 8 & 22 \\
TNNT2 & 14 & 13 & 1 \\
MYL2 & 8 & 7 & 1 \\
TNNI3 & 8 & 8 & - \\
ACTC & 5 & 5 & - \\
TPM1 & 5 & 5 & - \\
MYL3 & 2 & 2 & - \\
TTN & 1 & 1 & \\
\hline
\end{tabular}

\section{Mutations in the alpha-cardiac actin gene, ACTC (CMH8 locus)}

Actins are involved in various types of cell motility and they are ubiquitously expressed in all eukaryotic cells [29]. Actins are highly conserved proteins consisting of 377 amino acids. The polymerization of globular actin (g-actin) leads to a structural filament ( $f$ actin) in the form of a two-stranded helix. In vertebrates, three main groups of actin isoforms, alpha, beta and gamma, have been identified. The alpha-actins are found in striated muscles and are a major component of the contractile apparatus. Two missense mutations were initially reported in the ACTC gene associated with a dilated form of cardiomyopathy [15]. Thereafter, Mogessen et al. reported ACTC mutations in families with FHC [30]. Recently three novel mutations (E99L, P164A and A331P) were identified in functionally distinct domains of alpha-cAct that were associated with an early onset and apical cardiac hypertrophy [31]. 


\section{Mutations in the cardiac troponin T gene, TNNT2 (CMH2 locus)}

Troponin $\mathrm{T}$ is the tropomyosin-binding subunit of troponin, which is required for thin filament regulation of contraction. It contains several putative functional domains: phosphorylation sites and protein-binding sites to alpha-tropomyosin, troponin I and troponin C. The gene TNNT2 is composed of 17 exons spread over $17 \mathrm{~kb}$ and gives rise to multiple isoforms by the use of alternative exons and alternative acceptor sites [32]. Thierfelder et al. succeeded to map the TNNT2 to chromosome 1q32 and presented three unrelated families with a missense mutation and one splicing site mutation in TNNT2 causing cardiac hypertrophy in affected family members [33]. The splice site mutation was predicted to function as a null allele leading to haploinsufficiency and the authors suggested that abnormal stoichiometry of sarcomeric proteins caused cardiac hypertrophy. Watkins et al. identified eight mutations in the TNNT2 gene and estimated that mutations in this gene account for approximately $15 \%$ of familial HCM cases [34].

\section{Mutations in the cardiac troponin I gene, TNNI3 (CMH7 locus)}

Because all the known FHC disease genes encoded major contractile elements in cardiac muscle, a Japanese group systematically screened cardiac sarcomere genes, including cardiac troponin I (TNNI3), and cardiac troponin C in a large group of unrelated patients with HCM. They found mutations in the TNNI3 in several FHC patients [35]. Family studies showed that an R145G mutation was linked to HCM and a L206Q mutation had occurred 'de novo' strongly suggesting that TNNI3 is the seventh FHC disease gene.

\section{Mutations in the alpha-tropomyosin gene, TPM1 (CMH3 locus)}

Tropomyosins are rigid rod-like ubiquitous proteins in the thin filament of the sarcomere. They associate with the actin filaments and contribute to the stability of the thin filament. The tissue-specific isoforms are generated by alternative splicing of the $\alpha$-tropomyosin pre-mRNA. Macleod and Gooding identified the sequence of the gene and Eyre et al. assigned the gene to chromosomal band $15 q 22[36,37]$. The tropomyosin gene gives rise to four isoforms. The alpha-tropomyosin gene, TPM1, has only 10 exons, which encode 284 amino acids. Four missense mutations have been described in TPM1 previously [33, 34]. Watkins et al. concluded that mutations in TPM1 are a rare cause of $\mathrm{HCM}$, accounting for approximately $3 \%$ of the cases. Recently, two novel TPM1 mutations have been reported, the E180V mutation being associated to the transition between hypertrophic and dilated cardiomyopathy [14], and the V95A mutation showing unique features of mild cardiac hypertrophy with a high mortality rate [38]. 


\section{Mutations in the cardiac myosin-binding protein C gene, MYBPC 3 (CMH4 locus)}

Cardiac myosin-binding protein $\mathrm{C}$ is located in the C-zone of the sarcomere A-bands and is tightly bound to myosin and titin. The $\mathrm{CMH}_{4}$ locus was found in 1993 on chromosome 11p13-q13 [39]. Human MYBPC3 was then localized by fluorescent in situ hybridization on chromosome 11p11.2 [40]. It was therefore anticipated that mutations in MYBPC 3 might cause FHC and indeed Bonne et al. and Watkins et al. simultaneously demonstrated splice mutations and a duplication in this gene in families with HCM [41, 42]. Subsequently, several groups found MYBPC3 mutations in FHC [43-48]. Most of the mutations produce a frame shift leading to a premature termination during translation, resulting in truncated proteins lacking at least the major myosin-binding site. MYBPC3 is the most frequent mutated gene in French families with HCM (personal communication). The mechanism by which the truncation mutations lead to FHC is not fully understood, because neither the truncated protein nor a decrease of the normal protein was detected in the myocardial tissue of two patients with a $M Y B P C 3$ mutation [44, 48]. However, several ex vivo analyses and mouse models with $M Y B P C 3$ mutations showed that truncated proteins are present in the tissue and may act as poison polypeptides in a dominant-negative manner on the structure and/or the function of the sarcomere [49-53].

\section{Mutations in the titin gene, $\mathrm{TTN}$ ( $\mathrm{CMH} 9$ locus)}

Titin is a giant sarcomeric protein, extending from the $M$-band to the Z-disk of striated muscle sarcomere [54]. It's the third filament protein of the sarcomere. Titin is essential in the assembly of the highly ordered sarcomeres of striated muscles and responsible for the elasticity of relaxed striated muscle. Titin interacts with numerous sarcomeric proteins and provides a mechanical linkage. Only one missense mutation (R740L) has been reported in exon 14 [55]. The substitution occurred in a nonconservative domain located within the alpha-actinin binding site. The titin mutation may cause HCM in this patient via altered affinity to alpha-actinin.

\subsection{Friedreich's Ataxia}

Friedreich's ataxia (FRDA) is the most common autosomal recessive ataxia, characterized by degeneration of the large sensory neurons and spinocerebellar tracts, cardiomyopathy and increased incidence of diabetes [56]. Initially, FRDA can be diagnosed with only an isolated HCM in young children even though additional features are not obvious, including ataxia, dysarthria and areflexia. The onset of the disease is before adolescence, most often between the age of 8 and 15 years, and is generally characterized by pyramidal weakness of the legs, dysarthria, nystagmus, diminished or absent tendon reflexes, Babinski sign, impairment of position and vibratory senses, scoliosis, pes cavus, and hammer toe. FRDA is caused by intronic GAA triplet repeat 
expansion in the frataxin gene [57], which is located on chromosome 9q13. The gene codes for a $18-\mathrm{kDa}$ mitochondrial protein of unknown function. Frataxin has distant homology to $C$. elegans and yeast genes, where it is associated with the mitochondrial membrane, playing a role in regulating mitochondrial iron transport and in the stability of DNA structure. FRDA is caused by severely reduced levels of frataxin. This leads to mitochondrial iron accumulation and to a subsequent defect of respiratory chain and aconitase, probably due to cellular sensitivity to oxidative stress. In most patients FRDA is due to GAA-triplet repeat expansions in the first intron of the frataxin gene but in some cases the disease is due to mutations in the coding region. Most patients are homozygous for the expansions of a GAA triplet repeat within the frataxin gene but a few patients are compound heterozygotes with a point mutation and the GAA-repeat expansion. Recently, the first conditional mouse models for FRDA were generated by homologous recombination, and they exhibit important pathophysiological and biochemical features of the human disease [58]. These mice represent the first mammalian models to evaluate treatment strategies for the human disease.

\subsection{Genetic analysis}

For diagnostic DNA analysis of FHC it is crucial first of all that the diagnosis is unequivocally made without including any false-positives. This is one of the most important steps for the following genetic analyses. It is important that the clinician distinguishes a primary form (only cardiac symptoms) from a secondary form (associated with non-cardiac symptoms). Another jimportant criterion is the age of onset. Primary HCM is rarely symptomatic in infants and children while secondary HCM can disclose at any age. If HCM is diagnosed in infants and children, clinicians should always add biochemical evaluation and investigation of the neurologic system and skeletal musculature. Careful analysis of the family history and examination of the patient, and, if possible of relatives provides additional information. A sporadic case of HCM can be acquired (non-genetic) or can arise from a "de novo" mutation. In case of a positive family history the transmission mode can indicate whether the familial disease is inherited as an autosomal dominant, autosomal recessive or X-linked trait. An exclusively maternal transmission is suggestive for a mitochondrial defect.

Because FHC is very heterogeneous, linkage analysis is mainly the first option to initiate DNA analysis. A number of informative markers, closely linked to candidate genes, are used to investigate whether the disease gene co-segregates with a distinct locus. It should be emphasized that in FHC (with at least three affected and some unaffected relatives), it is much easier to establish the genetic etiology than in sporadic patients. Yet there are some limitations. Sometimes families are too small to perform adequate linkage analysis. In addition, a late clinical presentation of the disease (late-onset) or the presence of asymptomatic patients may obscure linkage 
analysis. In that case, the known disease genes are directly screened for mutations. For linkage analysis, it is very important to choose highly informative microsatellite markers with a high degree of heterozygosity. If linkage is obvious, a putative candidate gene can be located and a switch to the identification of the gene defect is made. DNA analysis is initiated by screening the complete coding sequence including intronic flanking regions. Depending on the strategy of DNA analysis and the laboratory equipment, identification of a mutation may take quite some time. Sometimes the large size of the gene hampers large routine screenings. If no linkage can be established a genome-wide screen is a next option to investigate whether a novel locus is involved. When a mutation is found in a proband, its disease-causing effect should be confirmed. Mutation should segregate in the family and should be absent in at least 200 normal control chromosomes to exclude low rates of polymorphisms.

\subsection{Genotype-Phenotype relationships in familial hypertrophic cardiomyopathy}

Before genetic analyses, it was well known that the pattern and extent of left ventricular hypertrophy varies greatly from one individual to another and even in firstdegree relatives, and that a high incidence of sudden deaths occurs in some families [59]. Genetic studies have provided insight into the heterogeneity of FHC clinical features. However, the results must be seen as preliminary, because the available data relate to only a few hundred individuals, and it is obvious that although a given phenotype may be apparent in a small family, examining large or multiple families with the same mutation is required before drawing unambiguous conclusions. Several concepts nevertheless have emerged, at least for mutations in the MYH7, TNNT2 and $M Y B P C 3$ genes. For $M Y H 7$, it is clear that prognosis is very variable from one patient to the other (Category A) [60, 61, 8]. For example, the R403Q and R723G mutations appear to be associated with markedly reduced survival $[60,62]$, whereas some others, such as the V606M, appear more benign [61]. The disease caused by TNNT2 mutations is usually associated with a $20 \%$ incidence of non penetrance, a relatively mild and sometimes subclinical hypertrophy but a high incidence of sudden death which can occur even in the absence of significant clinical left ventricular hypertrophy (category A) $[34,63,64]$. In one family with a TNNT2 mutation, however, penetrance is complete, echocardiographic data show a wide range of hypertrophy and there was no sudden cardiac death [65]. Mutations in MYBPC3 seem to be characterized by specific clinical features with a mild phenotype in young subjects, a delayed age at the onset of symptoms and a favorable prognosis before the age of $40[66,46]$. Genetic studies have allowed the identification of patients with double mutations who develop a more severe form of the disease: compound heterozygous for $M Y H 7$ mutations [67], double heterozygous for $M Y H 7$ and $M Y B P C 3$ mutations [68] and homozygous for a $M Y H 7$ mutation [69]. In addition, a detailed analysis of a "de novo" mutation in a French 
family with HCM allowed the description of the first case of germline mosaicism in FHC [70]. This mosaicism had been inherited from the mother but did not affect her somatic cells. Genetic studies have also revealed the presence of clinically healthy individuals carrying the mutant allele, which is associated in first-degree relatives with a typical phenotype of the disease. Several mechanisms could account for the large variability of the phenotypic expression of the mutations: the degree of functional impairment caused in the sarcomere by the mutation (that may vary markedly with the position of the mutation in the molecule and the type of protein involved), the role of environmental differences and acquired traits (e.g., differences in lifestyle, risk factors, and exercise) and finally the existence of modifier genes and/or polymorphisms that could modulate the phenotypic expression of the disease. The only significant results obtained so far concern the influence of the angiotensin I converting enzyme insertion/deletion (ACE I/D) polymorphism. Association studies showed that, compared to a control population, the D allele is more common in patients with HCM and in patients with a high incidence of sudden cardiac death [7173]. It was also shown that the association between the $D$ allele and hypertrophy is observed in patients with a MYH7 R403 codon mutation, but not in MYBPC3 mutation carriers [74], raising the concept of multiple genetic modifiers in FHC. The genetic status begins to be used as the criterion of reference to reassess diagnostic criteria and penetrance. The diagnosis of FHC is usually based on ECG and echocardiography, and it is generally accepted that echocardiography is a more accurate technique than ECG for the diagnosis in adults [5]. Analysis of a large genotyped population showed that, in fact, ECG and echocardiography have similar diagnostic values for FHC in adults, with an excellent specificity and a lower sensitivity [75]. As for penetrance, it was a muchdebated issue. Before molecular genetics analyses, several studies have indicated either a full penetrance [76], or an incomplete one [77, 78]. The penetrance of FHC has been re-assessed in a large French genotyped population, and it was found that it is incomplete, age-related and greater in males than in females [79]. This latter data has very important implications for genetic counseling especially for women under the age of fifty. One of the transgenic mouse models of FHC also shows a gender difference [80] and it provides now a good genetic model to look for a direct role of sexual hormones on myocardium and to study the role of putative modifier genes on sexual chromosomes.

\subsection{Therapy in HCM}

Two separate therapeutic approaches can be followed in HCM patients. One aimed at blocking the progression of hypertrophy and alleviating cardiac symptoms. The second target is prevention of arrhythmias [80]. There are three groups of individuals that should be distinguished: 1) Patients with complaints related to HCM, 2) Patients with 
hypertrophy, but no complaints, and 3) Carriers without disease characteristics and symptoms:

1) The need to treat patients with complaints is obvious, although the optimal treatment is not known. The wide range of therapeutic options going from pharmacological, pacing, alcohol ablation, to surgical tissue resection in an attempt to improve cardiac function and reduce complaints is indicative for the confusion. All studies have different inclusion and assessment criteria, making comparisons between reports an arduous task. Different drugs have been tested, including $\mathrm{Ca}^{2+}$-entry blockers, beta-adrenoceptor blockers and ACE inhibitors. Early studies with $\mathrm{Ca}^{2+}$-entry blockers indicate beneficial short-term effects on diastolic function, but only minor improvement after 6 month (considered to be long term in this study) [81]. Many studies focus on the reduction of the outflow tract obstruction, but it is questionable how important this is for symptoms and prognosis [81-84]. A retrospective study in the UK concluded improved survival in HCM children treated with high dose betaadrenoceptor blockers [83]. It has been shown that the outflow tract gradient can be reduced by left or biventricular pacing, septal alcohol injection or partial septal resection, with short term relieve of symptoms. These treatment modalities can be beneficial for the individual patient. With respect to arrhythmias, it is obvious that amiodarone has been drug of choice in this disease to relieve anginal complaints, prevent and treat atrial arrhythmias and prevent and control ventricular arrhythmias. There is little debate on the place of amiodarone in this patient group as shown by different studies, the question of course is whether implantable cardioverter defibrillators (ICD) are superior, which seems to be the case [85, 86]. All patients with an outflow tract obstruction (including the asymptomatic patients) should receive endocarditis prophylaxis under the usual conditions.

2) Patients with the disease but without complaints will be less motivated to follow a strict drug regimen. How to attenuate the development of hypertrophy is again not well studied in this group. Rhythm control and sudden death prevention are important. Especially, in the setting of a family history with sudden death, or the identification of a mutation involved with a high incidence of sudden death (see above) would support prophylactic ICD placement. Again indicating the importance of the appropriate genetic diagnosis in this disease (Category A). The role of a preimplantation electrophysiological study is less obvious [85].

3) If you carry a mutation, does that make you a patient, in the absence of any signs of cardiac disease? For most individuals the answer is no. There are no reports on sudden death in gene carriers, without left ventricular disease. However, in the setting of troponin T mutations the situation is different as the signs of hypertrophy can be minor or absent, while a high incidence of sudden death has been reported $[34,63$, 
64]. Therefore, in these individuals, implantation of an ICD should be considered in the absence of any sign of disease.

\section{Conclusions}

It has become clear that the genetic basis of this group of cardiac disorders is extremely heterogeneous, thus complicating successful and fast identification of the causative molecular defect. During the differential diagnostic ways it is of crucial importance that the cardiologist establishes the type of cardiomyopathy and that the clinical geneticist adequately determines the mode of inheritance. In this respect it should be realized that cardiac tissue - paraffin-embedded or liquid nitrogen frozen, which is obtained from a deceased HCM patient is as suitable for genotyping as blood from alive subjects. The availability of this material can greatly accelerate adequate genotyping. Once the defect has been characterized it will be possible sometimes to offer patients or asymptomatic gene-carriers adequate therapeutic advice and suggest interventions to slow down further progress of the disease. Identification of the disease causing genes will be the basis for cell-biological studies, which may give insights into the pathogenesis of this group of cardiomyopathies. A fast method to screen multiple genes for pathologic mutations can be implemented in the new "microarray" technology. Soon, genotyping will be a mature and indispensable diagnostic tool to reveal the true nature of these cardiac disorders.

The aim for the near future is not only to identify new genes - major or modifiers involved in HCM but also to better understaind the molecular mechanisms by which the mutations lead to FHC. The analyses of human myocardial tissue, the ex vivo and in vitro studies, and the development of animal models by homologous recombination strategy will all help to investigate the pathogenesis of human FHC mutations.

\section{References}

1. Vulpian A, Contribution à l'étude des rétrécissements de l'orifice ventriculo-aortique. Archiv Physiol., 1868;3:220-222.

2. Brock R, Functional obstruction of the left ventricle. Guys Hosp Rep., 1957;106:221-238.

3. Teare D, Asymetrical hypertrophy of the heart in young adults. Br Heart J, 1958;20:1-208.

4. Wigle ED, Sasson Z, Henderson MA, et al., Hypertrophic cardiomyopathy. The importance of the site and the extent of hypertrophy. A review. Prog Cardiovasc Dis, 1985;28:1-83.

5. Maron BJ, Bonow RO, Cannon RO, et al., Hypertrophic cardiomyopathy: interrelations of clinical manifestations, pathophysiology, and therapy. N Engl J Med, 1987:316:780-9 and 844-852.

6. McKenna WJ and Camm AJ, Sudden death in hypertrophic cardiomyopathy: assessment of patients at high risk. Circulation, 1989;80:1489-1492.

7. Maron B, Hypertrophic cardiomyopathy. Lancet, 1997;350:127-133.

8. Spirito P, Seidman CE, Mckenna WJ, et al., The management of hypertrophic cardiomyopathy. N Engl J Med., 1997;336:775-785.

9. Maron BJ, Olivotto I, Spirito P, et al., Epidemiology of hypertrophic cardiomyopathy-related death:revisited in a large non-referral-based patient population. Circulation, 2000;102:858-864. 
10. Maron BJ, Gardin JM, Flack JM, et al., Prevalence of hypertrophic cardiomyopathy in a general population of young adults: echocardiographic analysis of 4111 subjects in the CARDIA study. Circulation, 1995;92:785-789.

11. Hollman A, Goodwin JF, Teare D, et al., A family with obstructive cardiomyopathy (asymetrical hypertrophy). Br Heart J, 1960;22:449-456.

12. MacRae CA, Ghaisas N, Kass S, et al., Familial hypertrophic cardiomyopathy with Wolff-ParkinsonWhite Syndrome maps to a locus on chromosome 7q3. J Clin Invest, 1995:96:1216-1220.

13. Patton KK, Niimura $\mathrm{H}$, Soults J, et al., Sarcomere protein gene mutations: a frequent cause of elderly-onset hypertrophic cardiomyopathy. Circulation, 2000;102:178.

14. Regitz-Zagrosek V, Erdmann J, Wellnhofer E, et al., Novel Mutation in the-Tropomyosin Gene and Transition From Hypertrophic to Hypocontractile Dilated Cardiomyopathy. Circulation, 2000;102:e112-116.

15. Olson TM, Michels VV, Thibodeau SN, et al., Actin mutations in dilated cardiomyopathy, a heritable form of heart failure. Science, 1998;280:750-752.

16. Kamisago M, Sharma SD, DePalma SR, et al., Mutations in Sarcomere Protein Genes as a Cause of Dilated Cardiomyopathy. N Engl J Med, 2000;343:1688-1696.

17. Bonne G, Carrier L, Richard P, et al., Familial hypertrophic cardiomyopathy: from mutations to functional defects. Circ ReS, 1998;83:579-593.

18. Fung DC, Yu B, Littlejohn T, et al., An online locus-specific mutation database for familial hypertrophic cardiomyopathy. Hum Mutat, 1999;14:326-332.

19. Paré JAP, Fraser RG, Pirozynski WJ, et al., Hereditary cardiovascular dysplasia: a form of familial cardiomyoapthy. Am J Med, 1961;31:37-62.

20. Jarcho JA, MCKenna W, Pare JAP, et al., Mapping a gene for familial hypertrophic cardiomyopathy to chromosome 14ql. N Engl J Med. 1989:321:1372-1378.

21. Geisterfer-Lowrance AAT, Kass S, Tanigawa G, et al., A molecular basis for familial hypertrophic cardiomyopathy: a beta cardiac myosin heavy chain gene missense mutation. Cell, 1990;62:999-1006.

22. Epstein N, Lin H, and Fananapazir L, Genetic evidence of dissociation (generational skips) of electrical from morphologic forms of hypertrophic cardiomyopathy. Am J Cardiol, 1990;66:627-631.

23. Hejtmancik JF, Brink PA, Hill R, et al., Localization of gene for familial hypertrophic cardiomyopathy to chromosome $14 \mathrm{ql}$ in a diverse US population. Circulation, 1991;83:1592-1597.

24. Ko YL, Lien WP, Chen JJ, et al., No evidence for linkage of familial hypertrophic cadiomyopathy and chromosome $14 \mathrm{ql}$ locus D14S26 in a chinese family: evidence for genetic heterogeneity. Hum Gen, 1992;89:597-601.

25. Schwartz K. Dufour C, Fougerousse F, et al., Exclusion of myosin heavy chain and cardiac actin gene involvement in hypertrophic cardiomyopathies of several french families. Circ Res, 1992;71:3-8.

26. Macera MJ, Szabo P, Wadgaonkar R, et al., Localization of the gene encoding for ventricular myosin regulatory light chain (MYL2) to human chromosome 12q23q24.3. Genomics, 1992;13:765-772.

27. Poetter $\mathrm{K}$, Jiang $\mathrm{H}$, Hassanzadeh $\mathrm{S}$, et al., Mutation in either the essential or regulatory light chains of myosin are associated with a rare myopathy in human heart and skeletal muscle. Nature Genet, 1996;13:636-9.

28. Flavigny J, Richard P, Isnard R, et al., Identification of two novel mutations in the ventricular regulatory myosin light chain gene (MYL2) associated with familial and classical forms of hypertrophic cardiomyopathy. J Mol Med, 1998;76:208-214.

29. Kramer PL, Luty JA, and Litt M, Regional localization of the gene for cardiac muscle actin (ACTC) on chromosome 15g. Genomics, 1992;13:904-905.

30. Mogensen J, Klausen IC, Pedersen AK, et al., alpha-cardiac actin is a novel disease gene in familial hypertrophic cardiomyopathy. J Clin Invest, 1999:103:R39-43. 
31. Olson TM, Doan TP, Kishimoto NY, et al., Inherited and de novo mutations in the cardiac actin gene cause hypertrophic cardiomyopathy. J Mol Cell Cardiol, 2000;1687-1694.

32. Farza H, Towsend P, Carrier L, et al., Genomic organization, alternative splicing and polymorphisms of the human cardiac troponin T gene. J Mol Cell Cardiol, 1998;30:1247-1253.

33. Thierfelder L, Watkins H, MacRae C, et al., alpha-tropomyosin and cardiac troponin T mutations cause familial hypertrophic cardiomyopathy: a disease of the sarcomere. Cell, 1994:77:701-712.

34. Watkins $\mathrm{H}$, McKenna WJ, Thierfelder L, et al., Mutations in the genes for cardiac troponin T and alpha-tropomyosin in hypertrophic cardiomyopathy. N Engl J Med, 1995:332:1058-1064.

35. Kimura A, Harada H, Park JE, et al., Mutations in the cardiac troponin I gene associated with hypertrophic cardiomyopathy. Nat Genet, 1997;16:379-382.

36. Macleod AR and Gooding C, Human hTMalpha gene: expression in muscle and nonmuscle tissue. Mol CellBiol, 1988;8:433-440.

37. Eyre H, Akkari PA, Wilton SD, et al., Assignment of the human skeletal muscle alpha-tropomyosin gene (TPM1) to band $15 q 22$ by fluorescence in situ hydridization. Cytogenet. Cell Genet, 1995;69:15-17.

38. Karibe A, Tobacman LS, Strand J, et al., Hypertrophic cardiomyopathy caused by a novel alphatropomyosin mutation (V95A) is associated with mild cardiac phenotype, abnormal calcium binding to troponin, abnormal myosin cycling, and poor prognosis. Circulation, 2001;103:65-71.

39. Carrier L, Hengstenberg C, Beckmann JS, et al., Mapping of a novel gene for familial hypertrophic cardiomyopathy to chromosome 11. Nature Genet, 1993:4:311-313.

40. Gautel M, Zuffardi O, Freiburg A, et al., Phosphorylation switches specific for the cardiac isoform of myosin binding protein C: a modulator of cardiac contraction? EMBO J, 1995;14:1952-1960.

41. Bonne G, Carrier L, Bercovici J, et al., Cardiac myosin binding protein-C gene splice acceptor site mutation is associated with familial hypertrophic cardiomyopathy. Nature Genet, 1995;11:438-440.

42. Watkins $\mathrm{H}$, Conner D, Thierfelder L, et al., Mutations in the cardiac myosin binding protein-C gene on chromosome 11 cause familial hypertrophic cardiomyopathy. Nature Genet, 1995;11:434-437.

43. Carrier L, Bonne G, Bährend E, et al., Organization and sequence of human cardiac myosin binding protein C gene (MYBPC3) and identification of mutations predicted to produce truncated proteins in familial hypertrophic cardiomyopathy. Circ Res, 1997;80:427-434.

44. Rottbauer W, Gautel M, Zehelein J, et al., Novel splice donor site mutation in the cardiac myosinbinding protein-C gene in familial hypertrophic cardiomyopathy. Characterization of cardiac transcript and protein. J Clin Invest, 1997;100:475-482.

45. Moolman-Smook JC, Mayosi B, Brink P, et al., Identification of a new missense mutation in MyBP-C associated with hypertrophic cardiomyopathy. J Med Genet, 1998;35:253-254.

46. Niimura H, Bachinski LL, Sangwatanaroj S, et al., Mutations in the gene for cardiac myosin-binding protein C and late-onset familial hypertrophic cardiomyopathy. N Engl J Med, 1998;338:1248-1257.

47. Yu B, French JA, Carrier L, et al., Molecular pathology of familial hypertrophic cardiomyopathy caused by mutations in the cardiac myosin binding protein C gene. J Med Genet, 1998:35:205-210.

48. Moolman JA, Reith S, UhI K, et al., A newly created splice donor site in exon 25 of the MyBP-C gene is responsible for inherited hypertrophic cardiomyopathy with incomplete disease penetrance. Circulation, 2000;101:1396-1402.

49. Yang Q Sanbe A, Osinska $\mathrm{H}$, et al., A mouse model of myosin binding protein $\mathrm{C}$ human familial hypertrophic cardiomyopathy. J Clin Invest, 1998;102:1292-1300.

50. Flavigny J, Souchet M, Sébillon P, et al., COOH-terminal truncated cardiac myosin-binding protein C mutants resulting from familial hypertrophic cardiomyopathy mutations exhibit altered expression and/or incorporation in fetal rat cardiomyocytes. J Mol.Biol. 1999;294:443-456.

51. McConnell BK, Jones KA, Fatkin D, et al., Dilated cardiomyopathy in homozygous myosin-binding protein-C mutant mice. J Clin Invest, 1999;104:1235-1244. 
52. Yang $\mathrm{Q}$ Sanbe $\mathrm{A}$, Osinska $\mathrm{H}$, et al., In vivo modeling of myosin binding protein $\mathrm{C}$ familial hypertrophic cardiomyopathy. Circ Res, 1999;85:841-847.

53. Sébillon P, Bonne G, Flavigny J, et al., $\mathrm{COOH}$-terminal truncated human cardiac MyBP-C alters myosin filament organization. C. R. Acad. Sci., 2001:In Press.

54. Labeit S and Kolmerer B, Titins: giant proteins in charge of muscle ultrastructure and elasticity. Science, 1995;270:293-296.

55. Satoh M, Takahashi M, Sakamoto T, et al., Structural analysis of the titin gene in hypertrophic cardiomyopathy: identification of a novel disease gene. Biochem Biophys Res Comm, 1999;262:411-417.

56. Durr A, Cossee M, Agid Y, et al., Clinical and genetic abnormalities in patients with Friedreich's ataxia. N Engl J Med, 1996;335:1169-1175.

57. Campuzano V, Montermini L, Molto MD, et al., Friedreich's ataxia: autosomal recessive disease caused by an intronic GAA triplet repeat expansion. Science, 1996;8:1423-1427.

58. Puccio $H$, Simon D, Cossée $M$, et al., Mouse models for friedreich ataxia exhibit cardiomyopathy, sensory nerve defect and Fe-S enzyme deficiency followed by intramitochondrial iron deposits. Nature Genet., 2001;27:181-186.

59. Klues HG, Schiffers A, and Maron BJ, Phenotypic spectrum and patterns of left ventricular hypertrophy in hypertrophic cardiomyopathy: morphologic observations and significance as assessed by two-dimensional echocardiography in 600 patients. J Am Coll Cardiol, 1995;26:1699-1708.

60. Watkins H, Rosenzweig T, Hwang DS, et al., Characteristic and prognostic implications of myosin missense mutations in familial hypertrophic cardiomyopathy. N Engl J Med, 1992;326:1106-1114.

61. Fananapazir L and Epstein ND, Genotype-phenotype correlations in hypertrophic cardiomyopathy: Insights provided by comparisons of kindreds with distinct and identical beta-myosin heavy chain mutations. Circulation, 1994;89:22-32.

62. Enjuto M, Francino A, Navarro-Lopez F, et al., Malignant hypertrophic cardiomyopathy caused by the Arg723Gly mutation in beta-myosin heavy chain gene. J Mol Cell Cardiol, 2000;32:2307-2313.

63. Moolman JC, Corfield VA, Posen B, et al., Sudden death due to troponin T mutations. J Am Coll Cardiol, 1997;29:549-555.

64. Nakajima-Taniguchi C, Matsui H, Fujio Y, et al., Novel missense mutation in cardiac troponin T gene found in japanese patient with hypertrophic cardiomyopathy. I Mol Cell Cardiol, 1997; 29:839-843.

65. Forissier J-F, Carrier L, Farza H, et al., Codon 102 of the cardiac troponin T gene is a putative hot spot for mutations in familial hypertrophic cardiomyopathy. Circulation, 1996;94:3069-3073.

66. Charron P, Dubourg O, Desnos $\mathrm{M}$, et al., Clinical features and prognostic implications of familial hypertrophic cardiomyopathy related to cardiac myosin binding protein C gene. Circulation, 1998;97:2230-2236.

67. Nishi H, Kimura A, Harada H, et al., A myosin missense mutation, not a null allele, causes familial hypertrophic cardiomyopathy. Circulation, 1995:91:2911-2915.

68. Richard P, Isnard R, Carrier L, et al., Double heterozygosity for mutations in the beta myosin heavy chain and in the cardiac myosin binding protein C genes in a family with hypertrophic cardiomyopathy. J Med Genet, 1999:36:542-545.

69. Richard P, Charron P, Leclercq C, et al., Homozygotes for a R869C mutation in the beta-mysoin heavy chain gene have a severe form of familial hypertrophic cardiomyopathy. J Mol Cell Cardiol, 2000;32:1575-1583.

70. Forissier J.F, Richard P, Briault S, et al., First description of a germ line mosaicism in familial hypertrophic cardiomyopathy. I Med Genet, 2000;37:132-134.

71. Marian AJ, Yu Q-T, Workman R, et al., Angiotensin-converting enzyme polymorphism in hypertrophic cardiomyopathy and sudden cardiac death. Lancet, 1993:342:1085-1086. 
72. Lechin M, Quinones MA, Omran A, et al., Angiotensin-I converting enzyme genotypes and left ventricular hypertrophy in patients with hypertrophic cardiomyopathy. Circulation, 1995; $92: 1802-1812$.

73. Yonega $\mathrm{K}$, Okamoto $\mathrm{H}$, Machida $\mathrm{M}$, et al., Angiotensin-converting enzyme gene polymorphism in japanese patients with hyeprtrophic cardiomyopathy. Am Heart J, 1995;130:1089-1093.

74. Tesson F, Dufour C, Moolman JC, et al., The influence of the angiotensin I converting enzyme genotype in familial hypertrophic cardiomyopathy varies with the disease gene mutation. J Mol Cell Cardiol, 1997:29:831-838.

75. Charron P, Dubourg O, Desnos $M$, et al., Diagnostic value of electrocardiography and echocardiography for familial hypertrophic cardiomyopathy in a genotyped adult population. Circulation, 1997;96:214-219.

76. Clark CE, Henry WL, and Epstein SE, Familial prevalence and genetic transmission of idiopathic subaortic stenosis. N Engl J Med, 1973;289:709-714.

77. Maron BJ, Nichols PF, Pickle IW, et al., Patterns of inheritance in hypertrophic cardiomopathy. Assessment by M-mode and two-dimensional echocardiography. Am J Cardiol, 1984:53:1087-1094.

78. Greaves SC, Roche AHG, Neutze JM, et al., Inheritance of hypertrophic cardiomyopathy: a cross sectional and M mode echocardiographic study of 50 families. Br Heart J, 1987:58:259-266.

79. Charron P, Carrier L, Dubourg O, et al., Penetrance of familial hypertrophic cardiomyopathy. Genetic counseling, 1997;8:107-114.

80. Vikstrom KL, Factor SM, and Leinwand LA, Mice expressing mutant myosin heavy chains are a model for familial hypertrophic cardiomyopathy. Mol Med, 1996;2:556-567.

81. Tokushima T, Utsunomiya T, Ogawa T, et al., Short- and long-term effects of nisoldipine on cardiac function and exercise tolerance in patients with hypertrophic cardiomyopathy. Basic Res Cardiol, 1996;91:329-336.

82. Sherrid MV, Pearle G, and Gunsburg DZ, Mechanism of benefit of negative inotropes in obstructive hypertrophic cardiomyopathy. Circulation, 1998;97:41-47.

83. Ostman-Smith I, Wettrell G, and Riesenfeld T, A cohort study of childhood hypertrophic cardiomyopathy: improved survival following high-dose beta-adrenoceptor antagonist treatment. J Am Coll Cardiol, 1999;15:1813-1822.

84. Sherrid MV, Gunsburg D, and Sharma A, Medical treatment of hypertrophic cardiomyopathy. Curr Cardiol, 2000;2:148-153.

85. Zhu DW, Sun H, Hill R, et al., The value of electrophysiology study and prophylactic implantation of cardioverter defibrillator in patients with hypertrophic cardiomyopathy. Pacing Clin Electrophysiol, 1998;21:299-302.

86. Elliott PM, The Role of Pharmacologic Treatment to Prevent Sudden Death in the Implantable Cardioverter Defibrillator Era. Curr Cardiol Rep, 2001;3:167-172. 



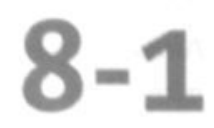

\section{GENOTYPE-PHENOTYPE CORRELATION IN FAMILIAL HYPERTROPHIC CARDIOMYOPATHY}

Genetic screening approach of the MYH7 gene in Familial Hypertrophic Cardiomyopathy associated with Sudden Cardiac Death

R.J. Jongbloed, P.A. Doevendans, J.M. Schmeitz-Mulkens, D. Tserpelis, I.M. van Langen, C.M. Marcelis, J.P. van Tintelen, J.G. Post, J.H. Tuerlings, A.A. Wilde, J.P. Geraedts and H.J. Smeets.

Submitted to: American Journal of Clinical Genetics 


\section{Abstract}

Aims. Generate and test an efficient screening protocol for identification of $\mathrm{MYH7}$ mutations associated with SCD. Background. Mutations in the beta-Myosin Heavy Chain gene (MYH7) cause a familial form of cardiac hypertrophy. Clinical manifestations of these mutations vary and have been classified as either benign or malignant depending on the occurrence and age of sudden cardiac death (SCD) in patients or families. A protocol was set up to rapidly identify malignant mutations associated with SCD. Methods and Results. A screening program was initiated by using a limited set of six exons, in which published malignant mutations have been shown to be clustered. Three novel missense mutations (Asn444Ser, lle736Thr and Val965Leu) and 4 previously reported missense mutations (Arg403Trp, Arg453Cys, Arg719GIn and Val606Met) were identified in 9 out of 60 families with cardiac hypertrophy and SCD. Conclusions. In $15 \%$ of the FHC families with a history of SCD, the disease-causing defect was identified. Some of these mutations were previously described as being benign, not associated with sudden death, indicating the complexity of strict genotype-phenotype predictions for risk stratification and treatment of individual patients.

\section{Introduction}

Sudden cardiac death (SCD) is a major cause of mortality in the western world. Among young ( $<35$ year) athletes SCD occurs in the setting of hypertrophic cardiomyopathy (HCM) in about $36 \%$ of cases [1]. In a large cohort of apparently healthy young adults selected from a community-based general population, the prevalence of echocardiographically defined HCM was estimated at $0.2 \%$ [1]. The predominant form is Familial Hypertrophic Cardiomyopathy (FHC) which has an autosomal dominant mode of inheritance and is genetically heterogeneous. Major clinical features include an increase in left and/or right ventricular muscle mass with often asymmetric thickness of the septum. On echocardiography an increased wall thickness of $>13 \mathrm{~mm}$ is considered abnormal. Morphological features of HCM are myofibrillar disarray and interstitial fibrosis leading to impaired relaxation and an altered contraction force, a hallmark of the disease. Typical complaints include exertional chest pain (angina pectoris), dyspnea, fatigue, palpitations and syncope. At physical examination a cardiac systolic murmur can be present [2]. SCD may be the first dramatic symptom of the disease. The overall annual mortality in adults with $\mathrm{FHC}$ is estimated to be $1 \%$, compared to $0.13 \%$ (age 34-75y) in the normal population [3, 4].

At present mutations in 10 genes, encoding sarcomeric proteins, have been identified that may cause FHC, with titin (TTN) as the most recent addition to the list [5]. Up to now more than 150 mutations within these genes have been listed in the FHC database [6]. Because FHC is such a genetically heterogeneous disorder, the most 
straightforward strategy to identify the genetic defect is linkage analysis followed by mutation analysis. However families are generally too small to perform linkage analysis, especially families with a high incidence of SCD in which genetic testing could be very helpful for early identification of individuals at risk. Since it is not feasible to completely screen all 10 genes simultaneously in a diagnostic setting we designed an efficient screening protocol aimed to specifically identify malignant, SCD correlated $\mathrm{FHC}$ mutations. This protocol focussed on the beta-myosin heavy-chain gene (MYH7) on chromosome 14, which contains about $33 \%$ of the reported FHC mutations [6]. As the impact of genetic diagnosis is most relevant in families with SCD, we only included SCD families in this first genotyping effort. By using this protocol we identified a missense mutation in 9 out of 60 unrelated small families with a history of SCD. Three mutations were novel and four mutations were reported previously. Some mutations previously considered benign and not associated with sudden death, were now identified in families with SCD at early age.

\section{Materials and methods}

\section{Diagnosis}

The clinical diagnosis of HCM was based on two dimensional echocardiography and Doppler recordings. The diagnosis was made if an unexplained ventricular wall thickness $>13 \mathrm{~mm}$ was found in the absence of other cardiac or systemic disorders [7]. The disorder was considered familial in the presence of a positive family history. In the Netherlands several academic centers have an outpatient clinic for inherited cardiovascular diseases. In these outpatient clinics a clinical geneticist and cardiologist collaborate in consulting individuals or families. If the diagnosis of FHC is made, informed consent is requested for obtaining medical information on family members and if possible, autopsy records of deceased patients. Furthermore, permission is obtained for genotyping. Pedigree information and blood samples are sent to the Genetic Department for genomic DNA extraction and genotyping. We selected index patients from 60 consecutive families with HCM (mean age 42y) and occurrence of at least one case of SCD in a family member before the age of 55 years.

\section{Genotyping}

Although the MYH7 gene consists of 41 exons, most of the malignant mutations are clustered within exons 13, 14, 16,19, 20 and 23 encoding the globular head and hinge or neck domain (Figure 1; S1-S2). These six exons were selected for the initial screening protocol. Peripheral blood samples were taken from patients and if available from their first degree family members. Genomic DNA was extracted by using high salt extraction method [8]. The target exons of the MYH7 gene were amplified by using intronic primers (Table 1). Primer pairs were based on the genomic sequence [9]. Exon 16 was divided in two separate amplification reactions (16a \& 16b). To detect 
differences in folding of denatured PCR products, Single Strand Conformation Polymorphism (SSCP) analysis was performed at $5^{\circ} \mathrm{C}$ and $15^{\circ} \mathrm{C}$ and amplicons with aberrant conformers were purified and analyzed by sequencing as described previously $[10,11]$.

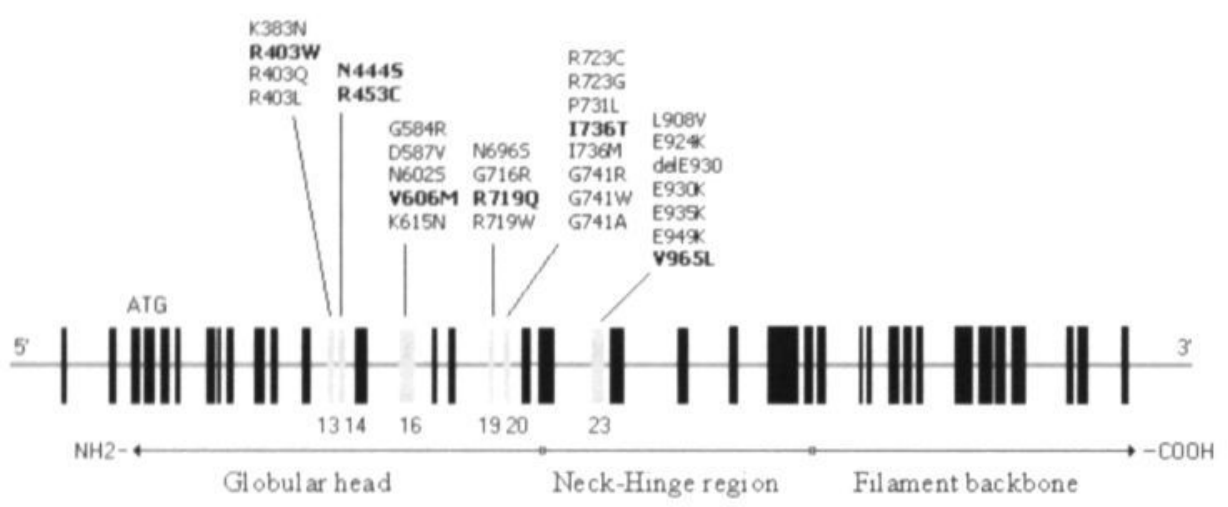

Figure 1. Schematic structure of the $M Y H 7$ gene and locations of the $\beta-M y H C$ protein domains. The translation start codon ATG (exon 3 ) is indicated and exons analyzed in this study are numbered and represented by gray boxes. Above the corresponding exons the mutations reported in this study (bold face) and mutations registered in the FHC database (www.angis.org.au/databases/) are indicated.

\section{Mutation Specific Restriction enzyme analysis}

Some of the previously described "malignant" missense mutations alter the DNA sequence, creating an additional or abolishing a specific restriction site. Following amplification the products were incubated with the appropriate restriction enzyme. Wild type and mutant DNA samples were discriminated by size fractionation using gel electrophoresis. In this study we used mutation specific restriction fragment analysis to identify the missense mutations Arg403Leu (exon 13) and Gly716Arg (exon 19) by using PflMI and Bsmal restriction endonucleases (Biolabs; Westburg) respectively [12, 13]. The missense mutations Arg403Trp, Arg453Cys and Arg719GIn presented in this study can be identified with restriction endonucleases Aval, Nlalll and Mspl (Biolabs; Westburg) respectively. Digested PCR products were analyzed by electrophoresis on $3 \%$ agarose gels. The pathogenicity of the novel mutations was based on the evolutionary conservation of the altered amino acid in the $\mathrm{MYH} 7$ of vertebrate striated muscle from different species, on the segregation in the family in relation to the disease and on the absence of the mutation in 110 alleles from healthy individuals [14]. 
Table 1. MYH7 primer combinations and PCR conditions

\begin{tabular}{|c|c|c|c|c|c|}
\hline Region & Primers & Sequence $5^{\prime} \rightarrow 3^{\prime}$ & Position (14) & $\begin{array}{c}\text { Temp } \\
{ }^{\circ} \mathrm{C}\end{array}$ & PCR product \\
\hline \multirow[t]{2}{*}{ Exon 13} & $13 \mathrm{~F}$ & TTACAGGCATGAACCACACACC & $8708-8729$ & 64 & 266 bp \\
\hline & $13 R$ & GTGAACTTGAAAACTCTCATCCC & $8952-8974$ & & \\
\hline \multirow[t]{2}{*}{ Exon 14} & $14 \mathrm{~F}$ & TCACTCTICCCAACAACCC & $8971-8988$ & 64 & 237 bp \\
\hline & $14 R$ & TGATTGTTCTCCCACTCCC & $9190-9208$ & & \\
\hline \multirow[t]{2}{*}{ Exon 16a } & $16 \mathrm{~F}-\mathrm{a}$ & TGAAGGACACTCAGTGATGC & $10181-10201$ & 64 & 212 bp \\
\hline & $16 R-a$ & GCCGGCATAGTGGATCAGGG & $10374-10393$ & & \\
\hline \multirow[t]{2}{*}{ Exon $16 \mathrm{~b}$} & $16 \mathrm{~F}-\mathrm{b}$ & CAAGGGGAAGCCTGAAGCCC & $10348-10367$ & 64 & 211 bp \\
\hline & $16 R-b$ & СTGTACCGGGAGCCTCAGTC & $10540-10559$ & & \\
\hline \multirow[t]{2}{*}{ Exon 19} & $19 / 20 F$ & СТCCTCCTACTTCCTTCTTC & $12011-12030$ & 60 & 183 bp \\
\hline & $19 R$ & СCCCTGTTCTATGAGCTTCT & $12174-12194$ & & \\
\hline \multirow[t]{2}{*}{ Exon 20} & 2OF & CAGAGCATGGGTGACTCTGG & $12267-12296$ & 60 & 216 bp \\
\hline & $19 / 20 R$ & GAGGAGTCAATGGAAAAGAG & $12464-12483$ & & \\
\hline \multirow[t]{2}{*}{ Exon 23} & $23 \mathrm{~F}$ & ССТССССТСTGTTCСТСАСC & $13941-12960$ & 64 & 299 bp \\
\hline & $23 R$ & CGGGCTGGAGCCAAAGGGAG & $14221-14240$ & & \\
\hline
\end{tabular}

\section{Results}

In 9 out of 60 probands (15\%) from HCM related SCD families, we identified 7 distinct missense mutations in the MYH7 gene (Figure 2). The limited number of living patients (1-3, average 2$)$ is obvious from the pedigrees presented and limits the genetic linkage analysis approach followed by genotyping. DNA results and main clinical features of the genotyped families are presented in Table 2. From most SCD cases (1-2 per family) no tissue or DNA was available for analysis. Three mutations were novel (Asn444Ser, lle736Thr and Val965Leu) and four mutations had been reported previously (Arg403Trp, Arg453Cys, Val606Met and Arg719GIn). Three apparently unrelated families carried the Val606Met mutation which appears be a more common mutation in the Dutch population.

\section{Novel missense mutations (Asn444Ser, lle736Thr and Val965Leu)}

In family B the novel missense mutation Asn444Ser (nt9097 A>G; exon14) was identified in a male patient (age 54y). His son suddenly died at age 23 while playing soccer. A sporadic case in family $H$ concerns a male proband (age $48 y$ ) with hypertrophic cardiomyopathy, ventricular arrhythmia, an aborted sudden cardiac death ( $\mathrm{aSCD}$ ) and a positive family history for SCD. His brother died suddenly at age $35 \mathrm{y}$ and his mother at age $58 \mathrm{y}$. In this family we identified the novel missense mutation lle736Thr (nt12347 T>C; exon 20) . Finally, in family I the novel missense mutation Val965Leu (nt14177 G>C; exon 23) was identified. In this family two brothers of the proband $(46 y)$, with clinical signs of hypertrophy, died suddenly at age 29 and $50 y$. Their father had cardiac hypertrophy and died suddenly at age 50y. 


\begin{tabular}{|c|c|c|c|c|c|c|c|c|}
\hline & Sex & Age years & $\begin{array}{l}\mathrm{HCM} / \\
\text { Mutation }\end{array}$ & $\begin{array}{l}\text { Effect of the } \\
\text { mutation }\end{array}$ & $\begin{array}{l}\text { MYH7 } \\
\text { exon }\end{array}$ & 2D Echocardiography & Electrocardiogram & Symptoms \\
\hline \multirow[t]{2}{*}{ A } & M & $S C D$ at 53 & - & $\begin{array}{l}R 403 W \\
8847 C>T\end{array}$ & 13 & $\cdot$ & $\cdot$ & \\
\hline & $F$ & 63 & $+1+$ & & & ASH $20 \mathrm{~mm}$ & $\begin{array}{l}\text { abnormal ST-T segment, } \\
\text { incomplete RBBB }\end{array}$ & dyspnoe exertion \\
\hline & M & 59 & $+1+$ & & & dubious septum hypertrophy & $\begin{array}{l}\text { 1st degree AV block, slow R- } \\
\text { progression }\end{array}$ & AP? \\
\hline & $F$ & 58 & $+1+$ & & & outflow tract gradient & - & dyspnoe exertion \\
\hline \multirow[t]{2}{*}{ B } & M & 54 & $+1+$ & $\begin{array}{l}\text { N444S } \\
9097 \mathrm{~A}>\mathrm{C}\end{array}$ & 14 & ASH, MI, enlarged LA & $\begin{array}{l}\text { conduction disturbances, } \\
\text { abnormal ST-T segments }\end{array}$ & collapse at age $28 \mathrm{y}, \mathrm{AF}$ \\
\hline & M & $S C D$ at 23 & $+1-$ & & & LVH, SH $17 \mathrm{~mm}$ & $\begin{array}{l}\text { sinus bradycardia, abnormal } \\
\text { ST-T segment, incomplete RBBB }\end{array}$ & SCD while sporting \\
\hline \multirow[t]{2}{*}{ C } & M & $S C D$ at 40 & $+1+$ & $\begin{array}{l}\text { R453C } \\
9123 C>T\end{array}$ & 14 & $\cdot$ & 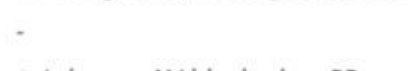 & \\
\hline & M & 54 & $+1+$ & & & ASH, MI, enlarged LA & $\begin{array}{l}\text { 1st degree AV block, slow PR } \\
\text { progression; large P waves }\end{array}$ & AF \\
\hline & M & 21 & $+1+$ & & & $\begin{array}{l}\text { LVH; outflow tract gradient } \\
1.5 \mathrm{~m} / \mathrm{sec} \text {, trace } \mathrm{MI}\end{array}$ & sinus bradycardia & no complaints \\
\hline & $\mathrm{F}$ & 11 & $+1+$ & & & MVP; LVH & normal & \\
\hline \multirow[t]{2}{*}{ D } & M & died at 41 & $\cdot$ & $\begin{array}{l}\text { V } 606 \mathrm{M} \\
10457 \mathrm{G}>\mathrm{A}\end{array}$ & 16 & - & - & myocardial infarction \\
\hline & $\mathrm{F}$ & $S C D$ at 57 & $+1-$ & & & known with $\mathrm{HCM}$ & - & \\
\hline & $F$ & 43 & $+1+$ & & & $\begin{array}{l}\text { SH } 23 \mathrm{~mm} ; \text { PW } 13 \mathrm{~mm} \text {; outflow } \\
\text { tract 43; SAM }\end{array}$ & non sustained VT & dizziness \\
\hline & M & SCD at 38 & - & & & known with $\mathrm{HCM}$ & $\cdot$ & \\
\hline & M & 17 & $-1+$ & & & $\cdot$ & - & \\
\hline \multirow[t]{4}{*}{ E } & $\mathrm{F}$ & $S C D$ at 40 & & $\begin{array}{l}\text { V606M } \\
10457 \mathrm{G}>\mathrm{A}\end{array}$ & 16 & $\cdot$ & - & \\
\hline & M & $S C D$ at 48 & $+1-$ & & & ASH $18 \mathrm{~mm}$ & abnormal ST-T segments & \\
\hline & $\mathrm{F}$ & 54 & $+1+$ & & & SH $15 \mathrm{~mm}$; atria dilated LVEF $36 \%$ & $\begin{array}{l}\text { LBBB, bradycardias, broad QRS } \\
\text { complex }\end{array}$ & $\begin{array}{l}\text { pacemaker, persistent } \\
\text { AF }\end{array}$ \\
\hline & $\begin{array}{l}F \\
F\end{array}$ & $\begin{array}{l}48 \\
42\end{array}$ & $\begin{array}{l}+1+ \\
01+\end{array}$ & & & normal (septum 9mm) & $\therefore$ & \\
\hline
\end{tabular}




\begin{tabular}{|c|c|c|c|c|c|c|c|c|}
\hline \multirow[t]{3}{*}{$\mathrm{F}$} & M & SCD at 58 & $\cdot$ & $\begin{array}{l}\text { V606M } \\
10457 \mathrm{G}>\mathrm{A}\end{array}$ & 16 & $\cdot$ & - & \multirow{7}{*}{$\begin{array}{l}\text { SCD while sporting; } \\
\text { collapse, souffle } \\
\text { dizzy, collapse, } \\
\text { arrhythmia } \\
\text { decreased stress } \\
\text { tolerance }\end{array}$} \\
\hline & $F$ & SCD at 48 & - & & & - & & \\
\hline & M & 23 & $+1+$ & & & $\begin{array}{l}\text { wall Th S15, PW } 13 \mathrm{~mm} \text {; outflow } \\
\text { tract gradient } 27\end{array}$ & & \\
\hline \multirow[t]{4}{*}{ G } & $\mathrm{F}$ & $S C D$ at 40 & $+1-$ & $\begin{array}{l}R 719 Q \\
12148 \mathrm{G}>C\end{array}$ & 19 & 然 & - & \\
\hline & $\mathrm{F}$ & 24 & $+1+$ & & & $\begin{array}{l}\text { SAM; IVS-EDWT 16-18mm; PW- } \\
\text { EDWT } 12 \mathrm{~mm} ; \mathrm{MI}\end{array}$ & LBBB, septum Q waves & \\
\hline & F & 22 & $+1+$ & & & $\mathrm{HCM}$ & & \\
\hline & $\mathrm{F}$ & 19 & $+1+$ & & & $\mathrm{HCM}$ & & \\
\hline \multirow[t]{3}{*}{ H } & $\mathrm{F}$ & SCD at 58 & $+1-$ & $\begin{array}{l}1736 \mathrm{~T} \\
12347 \mathrm{~T}>\mathrm{C}\end{array}$ & 20 & $\cdot$ & & pacemaker \\
\hline & M & $S C D$ at 35 & $+1-$ & & & known with $\mathrm{HCM}$ & & \\
\hline & M & 48 & $+1+$ & & & no significant LVH & $\begin{array}{l}\text { 1st degree AV block, enlarged P } \\
\text { wave; left axis }\end{array}$ & $\begin{array}{l}\text { near collapse, dyspnea } \\
\text { complaints }\end{array}$ \\
\hline \multirow[t]{4}{*}{ I } & M & $S C D$ at 50 & - & $\begin{array}{l}\text { V965L } \\
14177 \mathrm{G}>C\end{array}$ & 23 & $\cdot$ & . & dyspnea \\
\hline & $\begin{array}{l}M \\
M\end{array}$ & $\begin{array}{l}S C D \text { at } 50 \\
\text { SCD at } 29\end{array}$ & : & & & - & $\dot{.}$ & \\
\hline & $M$ & 46 & $+1+$ & & & ASH $15, \mathrm{~nm}$ & intermediate axis, mild ST & no complaints \\
\hline & $M$ & 42 & $+1+$ & & & ASH $25 \mathrm{~mm}$ & $\begin{array}{l}\text { elevations } \\
\text { septum } \mathrm{O} \text { waves, LVH }\end{array}$ & no complaints \\
\hline
\end{tabular}

'MYH7 codon numbering was according to the genomic sequence of the human cardiac beta-myosin heavy chain gene (12). The age of individuals at time of the clinical investigation is indicated in years. Symbol definitions: - no information available; $0 /+$ no hypertrophy, carrier of the MYH7 mutation; + / + hypertrophy, carrier of the MYH7 mutation; + / - hypertrophy, unknown genotype. Abbreviations: $A F=$ atrial fibrillation; $A P=$ angina pectoris; $A S H=$ asymmetrical septum hypertrophy; $F=$ Female; $L A=$ left atrium; LBBB= left bundle branch block; $L V E F=$ left ventricular ejection fraction; $L V H=l e f t$ ventricular hypertrophy; $M=$ Male; $M I=$ mitral valve insufficiency; $M V P=$ mitral valve prolaps; $P W=$ posterior wall; $R B B B=$ right bundle branch block; $S A M=$ subvalvular aortic motion; $\mathrm{SCD}=$ sudden cardiac death; $\mathrm{SH}=$ septum hypertrophy; $\mathrm{VT}=$ ventricular tachycardia. 

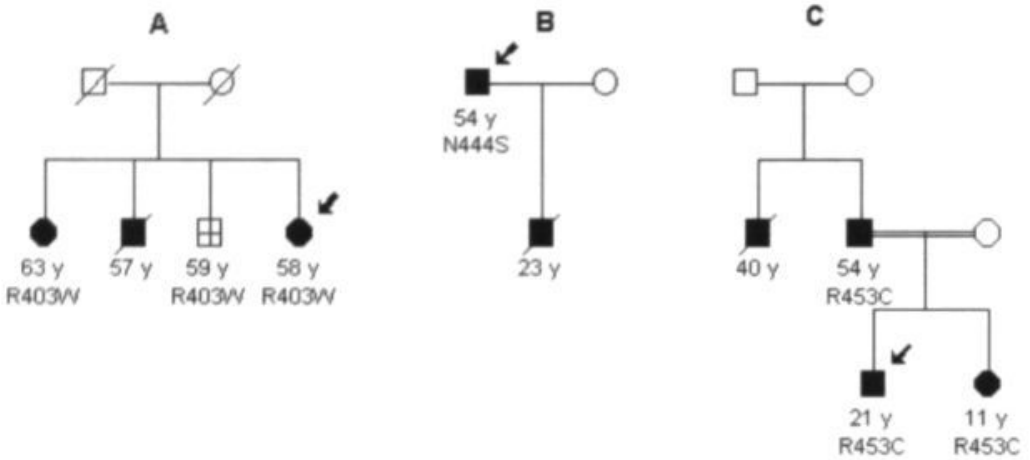

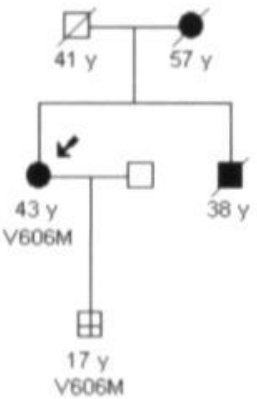

G

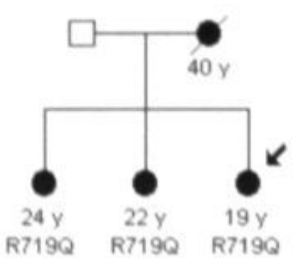

E

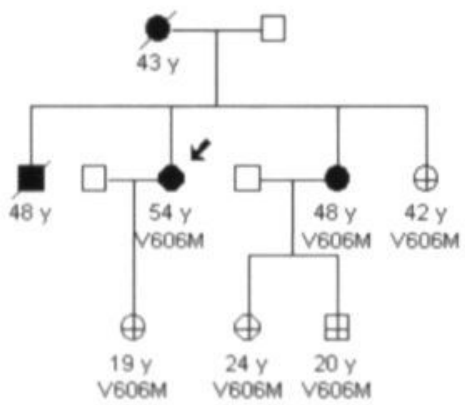

H

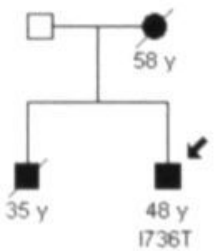

F

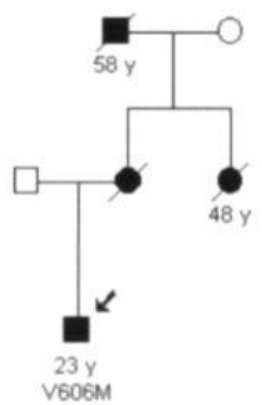

I

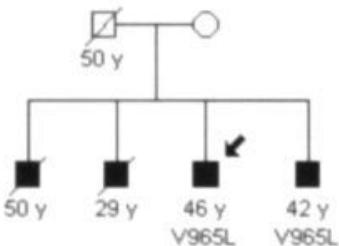

\section{Symbol definitions}

$\square \circ$ no clinical data

- hypertrophic cardiomyopathy

$\oplus$ 田 no clinical symptoms

Figure 2. Pedigrees of the SCD families. Pedigree symbols: squares indicate males; circles indicate females; symbols with diagonal slash, deceased family members; filled symbols, individuals with hypertrophic cardiomyopathy; unfilled symbols, individuals investigated without cardiac hypertrophy; Crossed symbols, carriers of the genetic defect without cardiac hypertrophy. An arrow refers to the family proband. Below pedigree symbols the genetic defect and the age of sudden death are indicated. Only family members with the genetic defect and their spouses are presented within the pedigrees. 


\section{Malignant missense mutations (Arg403Trp, Arg453Cys and Arg719GIn)}

In family A, a 58-year-old woman was carrier of a previously reported missense mutation Arg403Trp (nt8847 C>T; exon 13). She had mild aortic stenosis and marked left ventricular hypertrophy. Her brother, diagnosed with HCM suddenly died at age 53y. An elderly brother (age 59y) did not show clear clinical symptoms, although he had inherited the genetic defect. The mutation Arg403Trp was not detected by Pflml restriction analysis (which is a mutation specific assay for the R403Q mutation). The Arg453Cys (nt9123 C>T; exon 14) missense mutation was identified in family C from Pakistan origin. A 54-year-old male proband transmitted the mutation to his son (age 21y) and his daughter (age 11y) who already had clear signs of cardiac hypertrophy. A brother of the proband died suddenly at the age of 40y. No autopsy was performed. The proband (age 19y) in family G showed an aberrant SSCP conformer in exon 19 and after sequencing we identified a previously reported missense mutation Arg719GIn (nt12148 G>C; exon 19). Two older sisters of the proband had developed HCM at age 24 and $22 y$. Their mother died at age 40y. In this family the myocardial hypertrophy is predominantly located in the septum.

\section{Benign missense mutation (Val606Met)}

In three unrelated families (D, E and $F$ ) we identified the previously reported missense mutation Val606Met (nt10457 G>A; exon 16). The female proband (age 43) in family D had marked septal hypertrophy. Two family members with HCM died suddenly at age 38 and 57y. There were no biological samples left to confirm the mutation in the deceased family members or to proof paternal or maternal inheritance. Families $E$ and $F$ had incidences of sudden death at age $40,48 y ; 48 y$ and $58 y$. The only genotyped member of family $F$, had developed cardiac hypertrophy at age $23 y$.

\section{Discussion}

Identification of mutations causing familial hypertrophic cardiomyopathy (FHC) is important to elucidate the pathogenesis of this complex cardiac disorder. It has become of major significance for predictive genotype testing and genetic counseling of family members at risk of carrying a pathogenic mutation, although disease penetrance is incomplete and clinical manifestations of carriers with an identical mutation may vary [15]. Because of this phenotypic variability of reported mutations, it is difficult to predict the clinical manifestations in individual cases and to implement preventive treatment by genotyping alone. Meanwhile the question has been raised whether genotyping has a future role in guided risk-factor stratification [16]. This can only be achieved by analyzing large cohorts of patients with inexpensive, rapid and sensitive screening methods. By simplifying the genotyping protocol and by introducing the SCD as risk factor we attempted to improve the identification of mutations in families at risk of the most severe form of HCM. Based on literature data, 
we expected 11 mutations $(60 \times 0.33 \times 0.55)$ as $55 \%$ of the mutations identified in the $\mathrm{MYH7}$ gene are located within the limited number of six exons selected for the initial screening. We have identified 9 mutations which fits with the SSCP approach, which although being very rapid, may miss up to $20 \%$ of the mutations present. Our yield of mutations of $15 \%$ is much higher compared to the results of Ackerman et al who recently reported a yield of $1 \%$ by implementing an even more limited ( 3 exons) screening protocol [17]. They identified only one mutation in a total amount of 69 patients with a positive family history and at least one SCD before the age of 40 . If we had used their strategy analyzing only exons 13,14 and 19 we would have identified 4 mutations in 60 subjects $(6.7 \%)$. The discrepancy between the results may also originate from the selection criteria of the families included. We believe that the combination of well chosen clinical selection criteria and a carefully selected gene screening procedure will be most effective, both from a clinical and a financial point of view.

\section{Novel malignant missense mutations}

The novel mutation Asn444Ser resides, like the previously reported Arg453Cys malignant mutation, in the vicinity of the nucleotide-binding pocket domain which is associated with actin binding ( $\mathrm{S} 1$ domain) $[18,19]$. Position 444 is highly conserved in the myosin heavy chain protein from several species, indicating an important functional domain. The second novel missense mutation was identified in codon 736 (Ile736Thr) and presents a malignant phenotype in this family. Involvement of codon 736 was reported previously in a Japanese family where the amino acid isoleucine (Ile) was altered into methionine (Met) and also presenting a malignant phenotype [20, 21]. Both amino acid substitutions occurred in the same codon which is close to the binding site of the essential ventricular myosin light chain (MLC1). In a chicken MLC1 deficient model, a decrease of $50 \%$ of the velocity at which myosin moves actin was observed in a motility assay [22]. Similar results were reported in mice lacking the essential myosin light chain binding domain, demonstrating that alterations in myosin force transmission were sufficient to trigger the development of HCM in mice [23]. The third novel missense mutation Val965Leu concerns a highly conserved amino acid valine. The amino acid substitution occurred in the rod or $\mathrm{N}$-terminal part of the S2 segment of the MYH7 gene. Recently it was demonstrated that mutations in this $\mathrm{N}$ terminal part, like Arg870His and Glu924Lys, drastically reduce binding of myosin binding protein (MyBPC3). This protein contributes to the structural integrity of the sarcomere by binding the myosin heavy chain to the cytoskeleton protein titin [24].

\section{Known malignant missense mutations}

The three missense mutations (Arg403Trp, Arg453Cys and Arg719GIn) identified in this study, have been reported previously by several other investigators while some of these mutations have been studied with in vitro experiments and functional tests [19. 
25]. Codon 403 has been described as mutational "hotspot" and distinct mutations Arg403Leu, Arg403Trp and Arg403Gln have been reported in several studies [6, 26]. The Arg403Leu mutation is correlated with a high incidence of sudden cardiac death and the mutation Arg403Trp showed 100\% penetrance for developing hypertrophy [27]. An early onset of symptoms has been reported for the Arg403Trp mutation which also has been identified in this study [12]. Posen et al. described a large South-African pedigree of 64 members ( 31 affected) with the Arg403Trp mutation in which no SCD occurred, concluding that the mutation Arg403Trp was benign [28]. In the study presented here however, the mutation has a malignant phenotype as one family member died at a relative young age (family A). Watkins et al. constructed a KaplanMeier curve showing a correlation between a mutation at position 403 (Arg403Gln) and a high incidence of death at a young age [18]. In vitro studies in chicken skeletal muscle myosin and human slow-twitch muscle fibers showed that the Arg403Gln mutation strongly diminishes the motility and ATP-ase activity $[19,25]$ indicating that the 403 position is very important for muscle contraction. The second known malignant missense mutation is Arg453Cys. Watkins et al. suggested that carriers of a genetic defect, altering the charge of the amino acid as for example the arginine to cysteine substitution in codon 453 , had a significantly shorter life expectancy than carriers of mutations with no change of charge [18]. The mutation Arg453Cys is located at the surface of the protein facing towards the putative actin binding region and might therefore influence the catalytic function of the molecule [19]. Finally, the Arg719GIn mutation was reported previously in a family of Hispanic origin with an early age of onset of cardiac hypertrophy but no history of syncope or SCD and normal ECG's [29]. However, a second mutation that had occurred in codon 719 (Arg719Trp) was correlated with a high incidence of SCD at young age [13, 30, 31]. These observations indicate that mutations in codon 719 not always generate a malignant phenotype, which might depend on the change of charge or polarity of the amino acid substitution or on the role of modifiers in a different genetic background.

\section{Benign missense mutations}

The Val606Met mutation results in a neutral change of charge in the MHC protein and has often been reported with a favorable outcome and a mild phenotype in previously reported families labeling the mutation benign $[18,21]$. However Fananapazir et al reported a family with 4 cases of SCD (age 15-27y) and concluded that the Val606Met mutation is malignant in some kindreds [32]. Similar findings have been reported in an Australian and Japanese family [21, 33]. Later, also Havndrup et al. reported an unfavorable prognosis/outcome in one family with a high risk for sudden death at young age [34]. Our families present with a malignant phenotype as well, although it can not be excluded that in one family (Family $D$ ) another fatal inherited cardiac defect might be involved as the father of the proband died suddenly at relatively young age (41y) from a myocardial infarction. 


\section{Conclusions}

The aim of this study was to generate an efficient screening protocol with a high yield of malignant mutations in the beta-myosin heavy chain (MYH7) gene by including the risk factor of sudden cardiac death. By screening only those exons, known to harbor malignant mutations as well as the majority of the mutations, and by selecting specific families with reported early SCD, we identified the genetic defect in 9 out of 60 probands (15\%) which justifies our strategy. Two malignant missense mutations Arg403Leu (exon 13) and Gly716Arg (exon 19) previously reported as being correlated with a high incidence of SCD were not detected in this study [12, 26, 27, 29, 30]. However, we identified three novel malignant missense mutations (Asn444Ser, lle736Thr and Val965Leu) underlining the importance of DNA testing. In spite of the limited nature of the protocol, the mutation detection score was high (15\%), indicating the suitability of our rapid pre-screening protocol for malignant mutations in high-risk families. Being aware of the heterogeneous character of FHC we are developing a comparable screening protocol for the troponin T (TNNT2) gene which, despite moderate hypertrophy, has been associated with a high risk of sudden cardiac death [35, 36]. Initial unpublished results suggest a similar success rate. We conclude that our genotyping approach allows a rapid identification of the genetic defect in a high number of patients with $\mathrm{HCM}$ with $\mathrm{SCD}$ and opens the way to predictive testing of individuals at risk. For gene carriers identified cardiological follow-up by routine 2DEcho, ECG, X-test and Holter registration can be applied to monitor the progression of the disease so that clinical interventions can be implemented in time.

Acknowledgments. This work was partly supported by a grant from the Netherlands Heart Association (NHS95.014 to A.A.M. Wilde) and from the Interuniversity Cardiology Institute the Netherlands (ICIN) working group (Project 27 to A.A.M. Wilde and P.A. Doevendans).

\section{References}

1. Maron BJ. Hypertrophic cardiomyopathy, Lancet 1997:350:127-133.

2. Seidman CE, Seidman JG. Molecular genetics of inherited cardiomyopathies. In Molecular basis of cardiovascular diseases. K.R.Chien, editor, W.D Saunders. Philadelphia, USA 1999;251-263.

3. Doevendans PA. Hypertrophic Cardiomyopathy. Do We Have the Algorithm for Life and Death? Circulation 2000;101:1224-1226.

4. Akhtar M, Myerburg RJ, Ruskin JN. Sudden cardiac death. Prevalence, Mechanisms, and Approaches to Diagnosis and Management. Williams \& Wilkens editors, Malvern USA 1994.

5. Satoh M, Takahashi M, Sakamoto $T$ et al. Structural analysis of the titin gene in hypertrophic cardiomyopathy: identification of a novel disease gene. Biochem Biophys Res Commun 1999:262:411-417.

6. Fung DC, Yu B, Littlejohn $T$ et al. An online locus-specific mutation database for familial hypertrophic cardiomyopathy. Hum Mutat 1999:14:326-332.

7. Maron BJ, Gottdiener JS, Epstein SE. Patterns and significance of distribution of left ventricular hypertrophy in hypertrophic cardiomyopathy: a wide angle, two dimensional echocardiographic study of 125 patients. Am J Cardiol 1981;48:418-428. 
8. Muellerbach R, Lagoda PJL, Welter C. An efficient salt-chloroform extraction of DNA from blood and tissues. TIC 1989:5:391.

9. Liew CC, Sole MJ, Yamauchi-Takihara $\mathrm{K}$ et al. Complete sequence and organisation of the human cardiac $\beta$-myosine heavy chain gene. Nucleic Acids Res 1990;18:3647-3651.

10. Orita M, Suzuki $Y$, Sekiya $T$ et al. Rapid and sensitive detection of point mutations and DNA polymorphisms using the polymerase chain reaction. Genomics 1989:5:874-879.

11. Jongbloed RJ, Wilde AA, Geelen JL et al. Novel KCNQ1 and HERG missense mutations in Dutch longQT families. Hum Mutat 1999;13:301-310.

12. Dausse E, Komajda M, Fetler L et al. Familial hypertrophic cardiomyopathy. Microsatellite haplotyping and identification of a hot spot for mutations in the beta-myosin heavy chain gene. J Clin Invest 1993;92:2807-2813.

13. Anan R, Greve G, Thierfelder $L$ et al. Prognostic implications of novel beta cardiac myosin heavy chain gene mutations that cause familial hypertrophic cardiomyopathy. J Clin Invest 1994:93:280-285.

14. Cotton RGH, Scriver CR. Proof of 'Disease Causing' Mutation. Hum Mutat 1998;12:1-3.

15. Jongbloed RJE, Marcelis CL, Doevendans PA et al. Variable clinical manifestation of a novel missense mutation in the alpha-Tropomyosin (TPM1) gene in Familial Hypertrophic Cardiomyopathy. J Am Coll Cardiol 2003; 43: 981-986.

16. McKenna WJ, Mogensen J, Elliott PM. Role of genotyping in risk factor assessment for sudden death in hypertrophic cardiomyopathy. J Am Coll Card 2002;39:2049-2051.

17. Ackerman MJ, VanDriest SL, Ommen SR et al., Prevalence and age-dependence of malignant mutations in the beta-myosin heavy chain and troponin T genes in hypertrophic cardiomyopathy. A comprehensive outpatient perspective. J Am Coll Cardiol 2002;39: 2042-2048.

18. Watkins $\mathrm{H}$, Rosenzweig A, Hwang DS et al. Characteristics and prognostic implications of myosin missense mutations in familial hypertrophic cardiomyopathy. N Engl J Med 1992;326:1108-1114.

19. Rayment I, HM Holden, JR Sellers et al. Structural Interpretation of the Mutations in the B-Cardiac Myosin that have been Implicated in Familial Hypertrophic Cardiomyopathy. Proc Natl Acad Sci 1995;92:3864-3868.

20. Arai S, Matsuoka R, Hirayama K et al. Missense mutation of the beta-cardiac myosin heavy-chain gene in hypertrophic cardiomyopathy. Am J Med Genet 1995:58:267-276.

21. Semsarian C, Yu B, Ryce C et al. Sudden cardiac death in familial hypertrophic cardiomyopathy: are "benign"mutations really benign? Pathology 1997;29:305-308.

22. Bonne G, Carrier L, Richard P et al. Familial Hypertrophic Cardiomyopathy: From Mutations to Functional Defects. Circ Res 1998;83:580-593.

23. Welikson RE, Buck SH, Patel JR et al. Cardiac myosin heavy chains lacking the light chain binding domain cause hypertrophic cardiomyopathy in mice. Am J Physiol 1999;276:2148-2158.

24. Gruen $M$, Gautel $M$. Mutations in beta-myosin $\$ 2$ that cause familial hypertrophic cardiomyopathy (FHC) abolish the interaction with the regulatory domain of myosin-binding protein-C. J Mol Biol 1999;286:933-949.

25. Lankford EB, Epstein ND, Fananapazir L et al. Abnormal contractile properties of muscle fibers expressing beta-myosin heavy chain gene mutations in patients with hypertrophic cardiomyopathy. J Clin Invest 1995;95:1409-1414.

26. Moolman JC, Brink PA, Corfield VA et al. Identification of a new missense mutation at Arg403, a CPC mutation hotspot, in exon 13 of the beta-myosin heavy chain gene in hypertrophic cardiomyopathy. Hum Mol Genet 1993;2:1731-1732.

27. Epstein ND, Cohn GM, Cyran F et al. Differences in clinical expression of hypertrophic cardiomyopathy associated with two distinct mutations in the beta-myosin heavy chain gene. A 908Leu-Val mutation and a 403Arg-GIn mutation. Circulation 1992;86:345-352. 
28. Posen BM, Moolman JC, Corfield VA et al. A clinical and prognostic evaluation of familial hypertrophic cardiomyopathy in two South African families with different cardiac beta-myosin heavy chain gene mutations. Br Heart J 1995;74:40-46.

29. Consvage MW, Salada GC, Baylen BG et al. A new missense mutation, Arg719Gln, in the betacardiac heavy chain myosin gene of patients with familial hypertrophic cardiomyopathy. Hum Mol Genet 1994;3:1025-1026.

30. Greve G, Bachinski L, Friedman DL et al. Isolation of a de novo mutant myocardial betaMHC protein in a pedigree with hypertrophic cardiomyopathy. Hum Mol Genet 1994; 3: 2073-2075.

31. Abchee A, Marian AJ. Prognostic significance of beta-myosin heavy chain mutations is reflective of their hypertrophic expressivity in patients with hypertrophic cardiomyopathy. I Investig Med 1997:45: 191-196.

32. Fananapazir L, Epstein ND. Genotype-phenotype correlations in hypertrophic cardiomyopathy. Insights provided by comparisons of kindreds with distinct and identical beta-myosin heavy chain gene mutations. Circulation 1994;89:22-32.

33. Nakajima-Taniguchi C, Azuma J, Nagata S et al. A missense mutation in the beta-myosin heavy chain gene in a Japanese patient with hypertrophic cardiomyopathy. Jpn Circ J 1995;59:833-837.

34. Havndrup O, Bundgaard H, Andersen PS et al. The Val606Met mutation in the cardiac beta-myosin heavy chain gene in patients with familial hypertrophic cardiomyopathy is associated with a high risk of sudden death at young age. Am J Cardiol 2001;87: 1315-1317.

35. Moolman JC, Corfield VA, Posen B et al. Sudden death due to Troponin T mutations. J Am Coll Cardiol 1997;29: 549-555.

36. Varnava A, Baboonian C, Davison $F$ et al. A new mutation of the cardiac troponın I gene causing familial hypertrophic cardiomyopathy without left ventricular hypertrophy. Heart 1999;82: 621. 624. 


\section{8-2}

GENOTYPE-PHENOTYPE CORRELATION IN FAMILIAL HYPERTROPHIC CARDIOMYOPATHY

Variable clinical manifestation of a novel missense mutation in the alphatropomyosin (TPM1) gene in familial hypertrophic cardiomyopathy

R.J. Jongbloed, C.L. Marcelis, P.A. Doevendans, J.M. Schmeitz-Mulkens, G. Van Dockum, J.P. Geraedts and H.J. Smeets

Journal of the American Colleges of Cardiology 43:981-986 (2003) 


\section{Abstract}

Objectives. This study was initiated to identify the disease-causing genetic defect in a family with hypertrophic cardiomyopathy (HCM) and high incidence of sudden death.

Background. Familial hypertropic cardiomyopathy (FHC) is an autosomal dominant transmitted disorder that is genetically and clinically heterogeneous. Mutations in 11 genes have been associated with the pathogenesis of the disease. Methods. We studied a large FHC family, first by linkage analysis, to identify the gene involved, and subsequently screened the gene, encoding alpha-tropomyosin (TPM1), for mutations by using single-strand conformation polymorphism and sequencing analysis. Results .Twelve family members presented clinical features of HCM, five of whom died at young age, while others had only mild clinical features. Marker analysis showed linkage for the TPM1 gene on chromosome 15 q22 (maximal logarithm of the odds score is 5.16, $\theta=0$ ); subsequently, a novel missense mutation (Glu62Gln) was identified. Conclusions. The novel mutation identified in TPM1 is associated with the clinical features of cardiac hypertrophy in all but one genetically affected member of this large family. The clinical data suggest a malignant phenotype at young age with a variable clinical manifestation and penetrance at older age. The Glu62GIn mutation is the sixth TPM1 mutation identified as the cause of FHC, indicating that mutations in this gene are very rare. This is the first reported amino acid substitution at the $f$ position within the coiled-coil structure of the tropomyosin protein.

Abbreviations: $C M$; centiMorgan; $D C M$; dilated cardiomyopathy; $F H C$; familial hypertrophic cardiomyopathy; HCM; hypertrophic cardiomyopathy; LV; left ventricular; MYBPC; myosin binding protein C; MYH7; beta-cardiac myosin heavy chain; TNNT2; troponin T; TPM1; alpha-tropomyosin

Familial hypertrophic cardiomyopathy (FHC) is a clinically and genetically heterogeneous disease with an autosomal dominant mode of inheritance. Main clinical features are increased left ventricular (LV) and/or right ventricular muscle mass often in combination with asymmetric hypertrophy of the septum. On echocardiography, an increased cardiac muscle thickness (13 mm or more) is observed [1]. Typical complaints include chest pain (angina pectoris), shortness of breath (dyspnoea), fatigue, palpitations, and syncope. Sudden cardiac death may be the first dramatic symptom of the disease. The motion and contraction force of striated cardiac muscle cells is generated within the sarcomere by interaction between thick and thin filaments. Impaired relaxation and contraction force, a hallmark of FHC is generally caused by mutations in one of the sarcomere encoding genes. Until now, 11 genes have been reported as being involved in the development of FHC [2-4]. A total of 10 of the 11 genes encode cardiac proteins that assemble into contractile units (sarcomeres) of the cardiomyocytes. The genes that encode beta-cardiac myosin heavy chain (MYH7), myosin binding protein C (MYBPC 3$)$, and troponin T (TNNT2) account for approximately $75 \%$ of FHC (based on reported mutations). Recently, the gene PRKAG2 
(gamma 2 subunit of AMP-activated protein kinase) encoding a non-sarcomeric protein on chromosome $7 q$ was found to be involved in cardiac hypertrophy [5, 6]. In these patients, a complex of symptoms including conduction disturbances and WolfParkinson-White syndrome was demonstrated, probably related to glycogen storage $[7,8]$. In this paper we describe a large five-generation FHC family from the Netherlands. Linkage was identified with the alfa tropomyosin (TPM1) gene, and a novel mutation Glu62GIn (E62Q) was detected. The TPM1 gene is a very rare cause of FHC (approximately 5\%), except for the Finnish population where TPM1 mutations account for >11\% [9]. Until now, only eight missense mutations have been described within the TPM1 gene causing either hypertrophic (FHC) or dilated cardiomyopathy (DCM) [10-17]. The presence of the new mutation was associated with variable clinical features, although the mutation should be considered malignant, especially at younger age.

\section{Methods}

\section{Clinical studies}

A large five-generation Dutch family with FHC was analyzed in our institute. Family members were clinically evaluated by physical examination, two-dimensional echocardiographic examination, and 12-lead electrocardiography (ECG) analysis. Histopathological data of deceased family members were obtained when available. The clinical diagnosis of hypertrophic cardiomyopathy (HCM) was made if the interventricular septal thickness was $>13 \mathrm{~mm}$, in the absence of other cardiac or systemic causes of LV hypertrophy. In some family members, phenotypic assignment of cardiomyopathy was based on histopathological features of HCM at postmortem examination. Informed consent was obtained from each family member for genetic analysis.

\section{Genetic studies}

\section{Marker analysis}

Blood samples were collected from 22 individuals (clinically affected members and family members with no clinical symptoms of cardiac hypertrophy). Genomic DNA was extracted according to standard protocols [18]. Marker sets, used to test four candidate genes, were either located in the $5^{\prime}$ and 3 ' flanking regions of the genes or were intragenic. D1S2716 and D1S2622 at 2 to 2.5 centiMorgan (cM) proximal of the troponin T gene (TNNT2; chromosome 1932), marker D11S1344 and D11S1357 at 0.8 $\mathrm{CM}$ of the myosin binding protein C gene (MYBPC3; chromosome 11p11.2), two intragenic markers $\mathrm{MYOI}$ and MYOII for the $\beta$-beta-myosin heavy chain (MYH7; chromosome 14q12), and, finally, D15S159 and D15S993 at <0.5 cM for the alpha tropomyosin gene (TPM1; chromosome 15q22) [19-22]. Markers were derived from the Genome Database (GDB) and Genethon, labeled with fluorescent dyes and polymerase chain reaction amplified according to standard procedures. Fragment length analysis 
was performed by using the $\mathrm{ABI} 3100$ fragment gene analysis system (Applied Biosystems Inc., Nieuwerkerk a/d IJsel, the Netherlands) and Genescan analysis software version 3.7 (Applied Biosystems Inc.).

\section{Linkage analysis}

Linkage analysis was performed by using the ILINK module of the LINKAGE program version 5.1 [23]. Disease penetrance was estimated at $75 \%$ and disease frequency at $0.2 \%$.

\section{Mutation analysis}

Nine exons ( $1 a, 2 b, 3,4,5,6 b, 7,8$, and $9 a, b)$, comprising the entire coding sequence of the TPM1 gene in cardiac muscle, were amplified by using intronic primers as previously described [10]. Single-strand conformation polymorphism analysis was performed at $5^{\circ} \mathrm{C}$ and $15^{\circ} \mathrm{C}$, and amplicons with aberrant conformers were purified and analyzed by sequencing as described previously [24]. For diagnostic analysis, the mutation detection was performed by Mnll endonuclease (Roche, Almere, the Netherlands) of the PCR product of exon $2 \mathrm{~b}$ and analyzed by gel electrophoresis on $\mathrm{a}$ $3 \%$ Nusieve Agarose gel (FMC, Sanvertech, Boechout, Belgium).

\section{Results}

\section{Clinical characteristics}

The pedigree of the FHC family is presented in Figure 1, and main clinical characteristics are presented in Table 1. The family came to our attention because of the early sudden death of a mother (III.11) and four of her children (IV:16, IV:17, IV:18, and IV:19). The cause of her death was unclear, and no autopsy was performed. Postmortem evaluation of the two children (IV:16, IV:17) revealed severe asymmetric septal hypertrophy. Histology indicated myofibrillar disarray with interstitial fibrosis in the apical part of the septum and abnormal intramural coronary vessels. The third son (IV:8) was examined after the death of the oldest two sibs. He suddenly died at age 15. The youngest son (IV:19) was examined at age 17, and, at that time, he complained about fatigue. A few months later, he died suddenly. The father of this family remarried to a younger sister (III:13) of his first wife. Two children (IV:21 and IV:22) again showed HCM at age 33 and 35 years, respectively. Besides cardiac abnormalities, both were mentally retarded suffered spastic paralysis. The origin of their mental deficiency remains unclear. Their mother remained without complaints at age 67 years. She was frequently reinvestigated and did not show any signs of HCM on ECG or two-dimensional echocardiography. Only on magnetic resonance imaging investigation a septal hypertrophy ( $\max , 17 \mathrm{~mm}$ ) was found. In the other branch of this family, the diagnosis HCM was made for individual IV: 9 at routine screening for military services. At age 7 , his daughter $(\mathrm{V}: 3)$ was investigated for signs of $\mathrm{HCM}$. 
Electrocardiographic examination and echocardiography demonstrated signs of LV hypertrophy. At present she remains without complaints.

\section{Linkage of the TPM1 gene}

Because of maternal transmission in the right part of the pedigree (Fig.1), HCM-related and specific mitochondrial DNA mutations (A3243G, A3260G, C3303T, A4300G, A4269G, A43417G, G8344A, and T8993C/G) were excluded, as well as mitochondrial DNA deletions (data not shown). Marker analysis of 20 family members and two spouses of deceased members excluded the involvement of the MYH7, the MYBPC3, and the TNNT2 genes. Segregation of the alfa-tropomyosin (TPM1) markers were in line with a possible involvement of the TPM1 gene. Linkage analysis software revealed a maximum LOD score $Z(\theta)=5.16 \quad(\theta=0)$ (for markers D15S159 and D15S993. Subsequently, nine amplified exons of the TPM1 gene were screened by SSCP analysis. An aberrant conformer was identified in exon $2 b$ indicating a sequence variation. Sequence analysis showed a GAG to CAG transition at position 184 (complementary DNA reference sequence of TPM1, Genebank accession number M19713). The nucleotide substitution changes the amino acid glutamic acid of codon 62 into glutamine (Glu62Gln). In this family, the missense mutation segregated with the disease.

As the $G$ to $C$ substitution abolishes a Mnll restriction site, we applied Mnll restriction analysis to identify carriers of the genetic defect in all family members at risk. The pathogenicity of the mutation was based on exclusion of the mutation within a control group of 100 unrelated subjects (200 chromosomes) and by the localization of the substituted amino acid in an evolutionary highly conserved domain of the alphatropomyosin protein.

\section{Discussion}

Familial HCM is a clinically and genetically heterogeneous disorder. Incomplete penetrance and variable age-related clinical expression is often observed within and between families, even if an identical mutation is involved. At the moment, mutations in 11 genes have been identified that are involved in FHC, making linkage analysis the first step in identifying the genetic defect, as has been demonstrated in this family. In FHC families, however, a major problem is the high incidence of sudden death of affected family members and, because of that, no tissue or DNA is available for linkage studies. In this study, marker analysis showed statistically significant linkage with the TPM1 gene on chromosome15q22, and the causative mutation was identified in all clinically affected family members. The high conservation of the protein domain involved, and the absence in the control population, indicated that this mutation was very likely the cause of FHC in this family. 


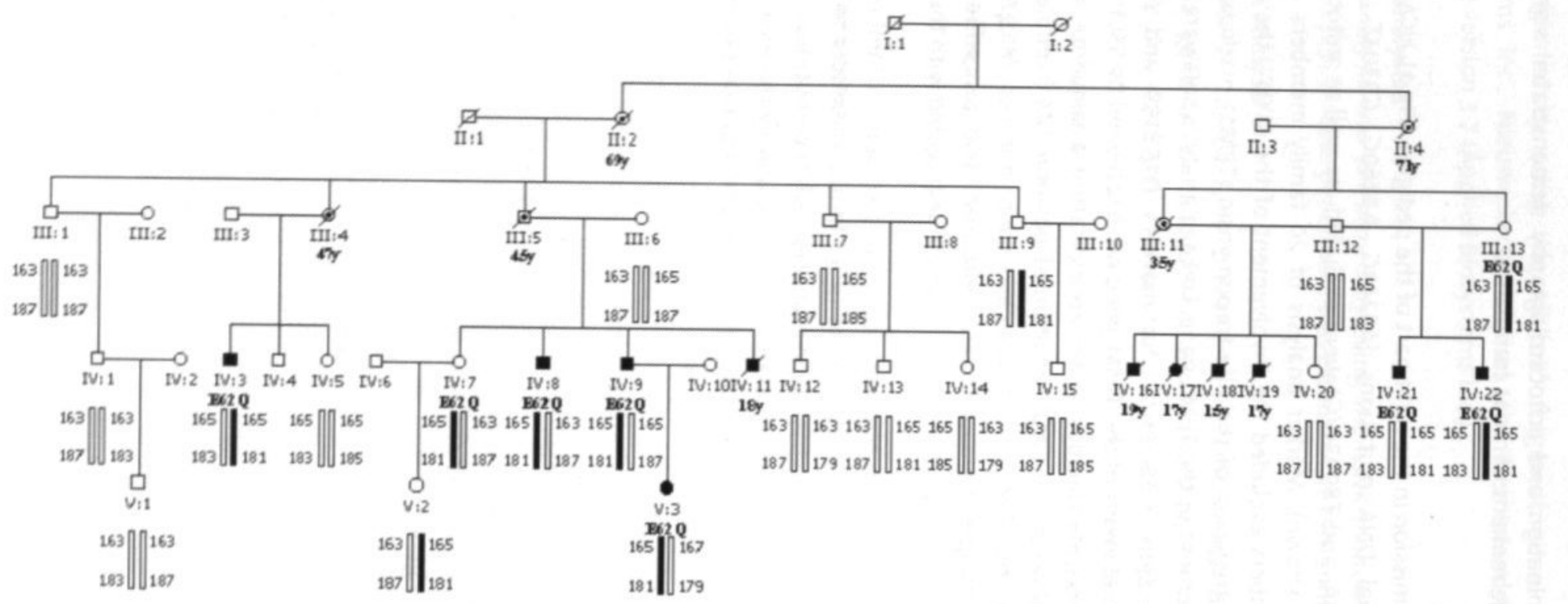

Figure 1. Five generation pedigree of the familial hypertrophic cardiomyopathy family. Pedigree symbols: squares = males; circles = females; symbols with diagonal slash = deceased family members; filled symbols = individuals with documented hypertrophic cardiomyopathy; dot within symbol = obligate carrier of the genetic defect; unfilled symbols = individuals without cardiac hypertrophy. Underneath the symbols are indicated the age (years) of sudden death and the genetically defined carriers of the mutation with $\mathrm{E} 62 \mathrm{Q}$ (Glu62 Gln). Bars = the haplotypes and numbers the alleles length (in basepairs) of the markers D15S159 (upper) and D15S993 (lower); filled bars = the risk haplotype 165 to 181. 
Table 1. Clinical features of the HCM family.

\begin{tabular}{|c|c|c|c|c|c|c|c|c|c|c|c|c|}
\hline \multirow[b]{2}{*}{ Pedigree } & \multirow[b]{2}{*}{ Gender } & \multirow[b]{2}{*}{ Age } & \multirow[b]{2}{*}{ E62Q } & \multirow[b]{2}{*}{ Clinical history } & \multicolumn{6}{|c|}{ 2D Echo } & \multirow[b]{2}{*}{ ECG } & \multirow[b]{2}{*}{ Remarks } \\
\hline & & & & & LVEF & SH & PW & ESD & EDD & others & & \\
\hline II. 2 & $F$ & & $(+)^{*}$ & SCD at $69 \mathrm{yrs}$ & NA & & & & & & NA & Obligate carrier \\
\hline 11.4 & $\mathrm{~F}$ & & $(+)$ & & NA & & & & & & NA & $\begin{array}{l}\text { Obligate carrier; } \\
\text { gynecological cancer at } \\
\text { age 71yrs }\end{array}$ \\
\hline III. 4 & $F$ & & $(+)$ & SCD at $47 \mathrm{yrs}$ & NA & & & & & & NA & Obligate carrier \\
\hline III.5 & M & & $(+)$ & SCD at 45 yrs & NA & & & & & & NA & Obligate carrier \\
\hline III.11 & $F$ & $?$ & $(+)$ & SCD at 35 yrs & NA & & & & & & NA & Obligate carrier \\
\hline III.13 & $\mathrm{F}$ & 67 & $+t$ & no complaints & Normal & & & & & & Normal & MRI: ASH $17 \mathrm{~mm} \ddagger$ \\
\hline IV.3 & M & 46 & + & no complaints & $66 \%$ & 16 & 14 & 23 & 41 & & LVH, abnormal ST-segments & \\
\hline IV.7 & $\mathrm{F}$ & 34 & + & Atypical complaints & Normal & & & & & & NA & \\
\hline IV.8 & M & 44 & + & PAF & $64 \%$ & 18 & 8 & 30 & 46 & SAM, MI & & \\
\hline IV.9 & M & 34 & + & PAF, dyspnea & $70 \%$ & 14 & 10 & 33 & 55 & SAM, MI & LVH, abnormal ST-segments & \\
\hline IV.11 & M & 18 & $(+)$ & $\begin{array}{l}\text { SCD at } 18 \text { yrs, } \\
\text { arrhythmia }\end{array}$ & NA & 31 & 10 & 24 & 38 & SAM & LVH, abnormal ST-segments & Died during catheterization \\
\hline IV.16 & M & 19 & $(+)$ & SCD at 19 yrs & NA & & & & & & NA & $\begin{array}{l}\text { PM: septal hypertrophy, } \\
\text { myofibrillar disarray + } \\
\text { fibrosis }\end{array}$ \\
\hline IV.17 & $F$ & 17 & $(+)$ & SCD at $17 \mathrm{yrs}$ & NA & & ; & & & & LVH & $\begin{array}{l}\text { PM: extensive septal } \\
\text { hypertrophy + LVH, RVH, } \\
\text { myofibrillar disarray + } \\
\text { fibrosis }\end{array}$ \\
\hline IV-18 & $M$ & 15 & $(+)$ & SCD at 15 yrs & $>50 \%$ & 15 & 10 & NA & NA & & LVH, abnormal ST-segments & \\
\hline IV.19 & M & 17 & $(+)$ & $\begin{array}{l}\text { SCD at } 17 \mathrm{yrs}, \\
\text { fatigue }\end{array}$ & $>50 \%$ & 24 & 13 & NA & NA & & $\begin{array}{l}\text { LVH, abnormal ST-segments, } \\
\text { sinus bradycardia }\end{array}$ & $\begin{array}{l}\text { PM: muscle degeneration, } \\
\text { interstitial fibrosis }\end{array}$ \\
\hline IV.21 & $M$ & 35 & + & no complaints & $70 \%$ & 18 & 12 & 29 & 49 & & Abnormal ST-segments & Mentally retarded spasticity \\
\hline IV.22 & M & 33 & + & no complaints & $>50 \%$ & 18 & Normal & 21 & 38 & MI & LVH, abnormal ST-segments & Mentally retarded spasticity \\
\hline V.3 & $F$ & 12 & + & no complaints & & 20 & & & & & LVH, abnormal ST-segments & Hypertrophy at age $5 y$ \\
\hline
\end{tabular}

"The (+) symbol indicates possible carrier of the mutation Glu62 Gln; $\uparrow$ the + symbol indicates carrier of the mutation Glu62Gln; $¥ \mathrm{MRI}$ : normal value <12mm.

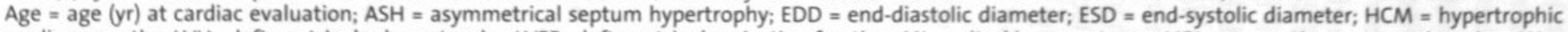

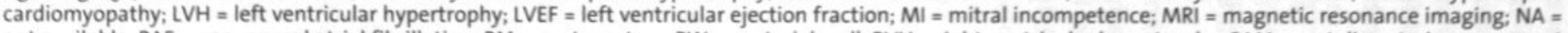

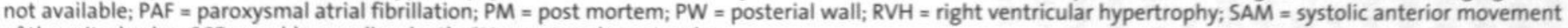
of the mitral valve; $S C D=$ sudden cardiac death; $\mathrm{SH}=$ septum hypertrophy. 
However, in this pedigree, the penetrance of the Glu62Gln mutation is incomplete, as one of the carriers with the mutation presents only with very mild hypertrophy at older age that might be missed by routine echocardiographic screening (Figure 1; individual III:13). These findings suggest that other genetic or environmental factors, yet unidentified, must be involved in modifying the effect of the mutation between family members. The clinical presentation of the novel mutation points towards a malignant (high incidence of sudden death) form of FHC with varying hypertrophy from mild to severe, in particular, asymmetrical septal hypertrophy. An interesting finding is the coronary abnormalities encountered during autopsy in patient IV:16. Despite marked initial thickening, there were no signs of old or fresh myocardial infarction. In addition, the localization of the fibrosis was not related to the site of coronary abnormalities. These findings make coronary disease a less likely cause of sudden death in this patient. In contrast, the extensive disarray combined with fibrosis and maybe local subendocardial ischemia could provide an arrhythmic substrate. Unfortunately, no serial measurements or Holter monitoring were performed in affected family members. No cases presented with HCM progressing into DCM.

Up to the present, only few TPM1 mutations have been reported, causing either hypertrophic (FHC) or DCM. Two mutations in exon 5, near the $\mathrm{Ca}^{2+}$-dependent troponin-T binding domain of the alpha-tropomyosin protein, have been associated with a transition from severe hypertrophy to DCM (Glu180Val) and with mild LV hypertrophy but poor prognosis (Glu180Gly) $[10,15]$. Within the same protein domain, a mutational hot spot at position Asp175Asn has been identified in five unrelated families (four Caucasian, one Japanese) with FHC $[9,10,12,13]$. The Asp175Asn mutation was studied in three families with full penetrance and seemed to be associated with a favorable prognosis [25]. Unique features of mild cardiac hypertrophy with a high mortality rate were described for the mutation Val95Ala in exon 3 [16]. The mutations Glu4olys and Glu54lys in exon $2 b$ occurred in an area that may alter the binding of alpha-tropomyosin to actin and have been associated with clinical features of DCM [17].

The TPM1 gene encodes a rigid rod-shaped protein. This protein is abundantly expressed in the striated muscle cells and various other tissues and forms a double helix coiled-coil structure by head-to-tail polymerization. Several isoforms result from the TPM1 gene by alternative splicing, and the adult cardiac isoform is encoded by only nine of the 14 exons. The protein is located within the thin filament of the sarcomere where it is associated with actin by twisting around the long axis of the actin filament as a coiled-coil dimer. It can bind seven consecutive actin monomers and, so, contributes to the stability of the thin filament [26]. Another thin filament component troponin $\mathrm{T}$ also has a binding site for tropomyosin. 
This binding site is thought to be responsible for positioning the troponin complex, which is composed of three polypeptides, troponin $\mathrm{T}, \mathrm{I}$, and $\mathrm{C}$, into the thin filament. The troponin-tropomyosin complex is $\mathrm{Ca}^{2+}$-sensitive. By raising the level of free calcium, the position of the tropomyosin-troponin complex is shifted, and the actin filaments can interact with the myosin heads of the thick filaments, which are active in the contracting muscle.

Our findings suggest that differences in clinical presentation may depend on the location of the amino acid substitution in the TPM1 helix. The novel mutation Glu62 Gln is the most 5' proximal missense mutation that has been reported in the TPM1 gene thus far, and which is associated with a malignant form of FHC.

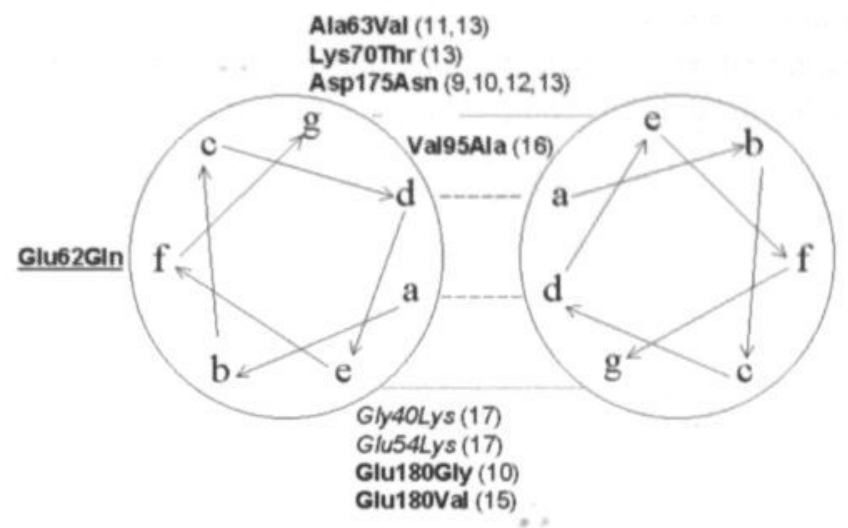

Figure 2. This figure has been redrawn according to Michele et al. 2000 [26] and represents the predicted coiled-coil structure of the alpha-tropomyosin gene (TPM1) alpha helix. The positions a to $\mathrm{g}$ represent the amino acids sequence of the heptad repeat that stretches along the entire alpha-tropomyosin protein. The view starts from the $\mathrm{N}$-terminus (position a) of the tropomyosin protein going down the axis of the tropomyosin dimer (position $\mathrm{g}$ ). The dotted lines represent the stabilizing interaction of charged amino acids between two tropomyosin molecules to form the coiled-coil dimer. Mutations associated with familial hypertrophic cardiomyopathy (bold) or dilated cardiomyopathy (italic) are indicated in the figure. The mutation Glu62 Gln identified in this study is underlined.

The negative-charged polar amino acid is replaced by an uncharged polar residue at a position on the outer surface of the coiled-coil [26]. In the coiled-coil filament of the tropomyosin molecule, the positions of the amino acids are arranged in an order of highly conserved heptad repeats along the entire length of the TPM1 protein [26, 27]. All mutations that have been reported previously and associated with FHC have occurred at the g-, d-, or e-position of the heptad repeat (Figure 2). The altered amino acids, which have been correlated with DCM, only occurred at the e-position. Two of the DCM-associated mutations change the acidic amino acid residue into a basic residue. Olson et al. [17] suggested that these mutations create a locally increased 
positive charge in the negatively charged surface of tropomyosin, changing the electrostatic interactions between actin and tropomyosin filaments. This novel Glu62Gln mutation is the first reported amino acid substitution at the f-position within the coiled-coil that changes the polarity of the amino acid and which is associated with hypertrophy. Further, it should be noticed that the amino acid variants at the positions 62,63 , and 70 are located within a protein domain with a function yet unidentified.

Reports of novel mutations within the TPM1 gene may help to unravel and define functionally important domains that are crucial for specific interaction with other (sarcomeric) proteins. Preliminary data of mutated amino acids in specific regions might indicate in which way the cardiomyopathy might develop, hypertrophy or dilation of the cardiac ventricles. By identifying the important domains for either disorder, better diagnostic and prognostic tools become available. Furthermore, the knowledge will help to elucidate the complex architecture of the sarcomere.

Supported, in part, by the Interuniversity Cardiology Institute the Netherlands (ICIN)

\section{References}

1. B.J. Maron, Hypertrophic cardiomyopathy. Lancet 1997:350: 127-133.

2. L. Carrier, R. Jongbloed, H. Smeets and P.A. Doevendans, Hypertrophic cardiomyopathy. In: P.A. Doevendans and A.A. Wilde, Editors, Cardiovascular Genetics for Clinicians, Kluwer Academic Publishers, Dordrecht 2001: 139-154.

3. A.J. Marian, Pathogenesis of diverse clinical and pathological phenotypes in hypertrophic cardiomyopathy. Lancet 2000;355:58-60.

4. H. Niimura, K.K. Patton, W.J. McKenna et al., Sarcomere protein gene mutations in hypertrophic cardiomyopathy of the elderly. Circulation 2002;105: 446-451.

5. M.H. Gollob, M.S. Green, A.S. Tang et al., Identification of a gene responsible for familial WolffParkinson-White syndrome. N Engl J Med 2001;344:1823-1831.

6. E. Blair, C. Redwood, H. Ashrafian et al., Mutations in the gamma2 subunit of AMP-activated protein kinase cause familial hypertrophic cardiomyopathy: evidence for the central role of energy compromise in disease pathogenesis. Hum Mol Genet 2001;10:1215-1220.

7. P.A. Doevendans and H.J. Wellens, Wolff-Parkinson-White syndrome: a genetic disease?. Circulation 2001;104:3014-3016.

8. M. Arad, D.W. Benson, A.R. Perez-Atayde et al., Constitutively active AMP kinase mutations cause glycogen storage disease mimicking hypertrophic cardiomyopathy. J Clin Invest 2002;109:357-362.

9. P. Jaaskelainen, M. Soranta, R. Miettinen et al., The cardiac beta-myosin heavy chain gene is not the predominant gene for hypertrophic cardiomyopathy in the Finnish population. J Am Coll Cardiol 1998;32:1709-1716.

10. L. Thierfelder, H. Watkins, C. MacRae et al., Alpha-tropomyosin and cardiac troponin T mutations cause familial hypertrophic cardiomyopathy: a disease of the sarcomere. Cell 1994;77:701-712.

11. C. Nakajima-Taniguchi, H. Matsui, S. Nagata, T. Kishimoto and K. Yamauchi-Takihara, Novel missense mutation in alpha-tropomyosin gene found in Japanese patients with hypertrophic cardiomyopathy. J Mol Cell Cardiol 1995;27:2053-2058.

12. H. Watkins, R. Anan, D.A. Coviello, P. Spirito, J.G. Seidman and C.E. Seidman, A de novo mutation in alpha-tropomyosin that causes hypertrophic cardiomyopathy. Circulation 1995;91:2302-2305. 
13. K. Yamauchi-Takihara, C. Nakajima-Taniguchi, H. Matsui et al., Clinical implications of hypertrophic cardiomyopathy associated with mutations in the alpha-tropomyosin gene. Heart 1996;76:63-65.

14. R. Bottinelli, D.A. Coviello, C.S. Redwood et al., A mutant tropomyosin that causes hypertrophic cardiomyopathy is expressed in vivo and associated with an increased calcium sensitivity. Circ Res 1998;82:106-115.

15. V. Regitz-Zagrosek, J. Erdmann, E. Wellnhofer, J. Raible and E. Fleck, Novel mutation in the alphatropomyosin gene and transition from hypertrophic to hypocontractile dilated cardiomyopathy. Circulation 2000;102:E112-116.

16. Karibe, L.S. Tobacman, J. Strand et al., Hypertrophic cardiomyopathy caused by a novel alphatropomyosin mutation (V95A) is associated with mild cardiac phenotype, abnormal calcium binding to troponin, abnormal myosin cycling, and poor prognosis. Circulation 2001;103:65-71.

17. T.M. Olson, N.Y. Kishimoto, F.G. Whitby and V.V. Michels, Mutations that alter the surface charge of alpha-tropomyosin are associated with dilated cardiomyopathy. J Mol Cell Cardiol 2001;33:723-732.

18. R. Muellerbach, P.J.L. Lagoda and C. Welter, An efficient salt-chloroform extraction of DNA from blood and tissues. Trends Genetics 1989:5:391.

19. J. Mogensen, P.S. Andersen, U. Steffensen et al., Development and application of linkage analysis in genetic diagnosis of familial hypertrophic cardiomyopathy. J Med Genet 38 (2001), pp. 193-198.

20. L. Carrier, C. Hengstenberg, J.S. Beckmann et al., Mapping of a novel gene for familial hypertrophic cardiomyopathy to chromosome 11. Nat Genet 1993;4:311-313.

21. E. Dausse, M. Komajda, L. Fetler et al., Familial hypertrophic cardiomyopathy: microsatellite haplotyping and identification of a hot spot for mutations in the beta-myosin heavy chain gene. J Clin Invest 1993;92:2807-2813.

22. Dib, S. Faure, C. Fizames et al., A comprehensive genetic map of the human genome based on 5,264 microsatellites. Nature 1996;380:152-154.

23. Linkage software analysis website: $h t t p / / l i n k a g e . r o c k e f e l l e r . e d u$

24. R.J. Jongbloed, A.A. Wilde, J.L. Geelen et al., Novel KCNQ1 and HERG missense mutations in Dutch long-QT families. Hum Mutat 1999;13:301-310.

25. D.A. Coviello, B.J. Maron, P. Spirito et al., Clinical features of hypertrophic cardiomyopathy caused by mutation of a "hot spot" in the alpha-tropomyosin gene. J Am Coll Cardiol 1997;29:635-640.

26. D.E. Michele and J.M. Metzger, Physiological consequences of tropomyosin mutations associated with cardiac and skeletal myopathies. J Mol Med 2000;78:543-553.

27. J.H. Brown, K.H. Kim, G. Jun et al., Deciphering the design of the tropomyosin molecule. Proc Natl Acad Sci 2001;98:8496-8501. 

GENERAL DISCUSSION 
Although LQTS and HCM are both clinically and genetically different diseases, they have in common that carriers of the gene defect can die suddenly from fatal cardiac arrhythmias. Both disorders are genetically heterogeneous and finding the genetic defect, explaining the pathology and providing prognostic information to individual asymptomatic gene carriers is still a major challenge.

\section{DNA-diagnostics LQTS and HCM}

The route from the patient to the identification of the gene defect involved can be based on several criteria as indicated in the diagnostic schemes (Figure $1 \& 2$ ). The choice of the first candidate gene is often determined by the genotype-phenotype correlation. For LQTS, specific abnormalities on ECG, the trigger of cardiac events, the frequency of the mutations found in the LQTS genes or linkage studies in families can guide to the gene involved. For HCM, this is less obvious and the (biased) frequency of mutations in sarcomeric genes is often the only parameter. A phenomenon like sudden cardiac death $(\mathrm{SCD})$ for example is not completely gene specific. Furthermore, genetic linkage studies are often hampered by the lack of living patients.

\section{Genetic screening protocol in LQTS and HCM}

Since mutation screening was initiated, it soon became obvious that both LQTS families and HCM families, have a "private" mutation, which means that most families have a unique family-specific mutation. This implies that for each "newly diagnosed LQTS or HCM family", all candidate genes have to be screened to identify the disease causing gene defect. Yet, a number of unrelated families have the same mutation since mutational "hot spots" do exist [1- 4]. These hot spots are CpG dinucleotides, in which the $\mathrm{C}$ nucleotide after methylation can deaminate and change into a $\mathrm{T}$ nucleotide. In rare cases even a founder mutation has been identified, which means that a large number of (related) families must have had a common ancestor who has been responsible for the transmission of a specific mutation with reduced penetrance $[5,6]$.

Because of this clinical complexity and genetic heterogeneity, it is not trivial to fulfill the diagnostic requests. A common strategy starts with amplification of the exons of the gene, most likely involved, followed by a pre-screening method and, subsequently, sequence analysis. Initially single strand conformation polymorphism (SSCP) analysis was used as a pre-screening method However, mutations may be missed as the estimated sensitivity of SSCP analysis is 70-80\% [7]. To increase sensitivity, Denaturing High Performance Liquid Chromatography (DHPLC) analysis has been applied, which has a claimed sensitivity of almost $100 \%$ [8]. This prescreening technique was successfully applied for LQTS index patients [9, chapter 4]. To date, the DHPLC technique has also been used successfully in the field of cardiovascular diseases to screen the TNNT2 gene, the PRKAG2 gene (unpublished results) and the entire 
mitochondrial DNA [10]. Soon, DHPLC analysis will also be developed for the screening of all other HCM candidate genes in an efficient way. In LQTS and HCM families, candidate genes can be excluded by marker analysis. However, in HCM and often LQTS, families are generally not large enough to positively identify a genetic locus. This is less problematic for the LQTS families as only 3 genes are predominantly involved, whereas more than 11 genes may be involved in HCM.

\section{Efficacy and efficiency of the genetic screening effort}

\section{Long QT syndrome}

In many prescreening methods, like DHPLC, the identification of a 'disease causing' mutation is based on PCR amplification and heteroduplex analysis (of the wild type and the mutated DNA). With respect to this approach, a number of aspects are of importance. The DHPLC method is PCR based and therefore, large deletions chromosomal rearrangements can remain undetected. Conventional Southern blot analysis or quantitative PCR approaches should be pursued in addition to the DHPLC screening if mutation detection fails. Further, in case of homozygous mutations, the amplified DNA fragments cannot form heteroduplexes and these mutations may be missed although, in some cases a mobility shift of mutated DNA-homoduplexes can be observed. As LQTS is a dominant disorder, this is not a major problem as heterozygosity is the rule. However, double mutations (homozygous and compound heterozygous) do rarely exist and have been reported in some severe cases of LQTS [11]. In the past, a homozygous mutation in the HERG gene (LQT2) gene has been reported to cause intrauterine arrhythmia and, in the SCN5A gene (LQT3) a homozygous mutation caused a 2:1 AV block in a 5-year-old boy [12,13]. Homozygous mutations in LQT2 and LQT3 are rare and are, like homozygous mutations in LQT1 (involved in JLNS), associated with severe ventricular arrhythmias $[5,6]$. Additionally, finding a mutation in a certain gene, the order of the exons that have to be screened can also be time-saving. Because of the high incidence of mutations that have been reported in exons which encode the pore and the transmembrane spanning domains (S1-S6), genetic analysis of the potassium channels KCNQ1 and KCNH2 is preferentially initiated in these exons (LQTS database: http://pc4.fsm.it:81/cardmoc/). The mutation detection in the SCN5A gene is preferentially initiated at the $3^{\prime}$ end of this gene (starting from exon 28 to exon 1) as a large number of mutations has been identified within the final two domains of the SCN5A gene.

In our study 87 LQTS index patients were analyzed, originating from 34 families with more than one affected family member and 43 single cases. All families, except two, originated from the Caucasian population. The two exceptions were Asian families. In addition, 10 individual cases with an acquired form of LQTS were tested as well. In families where linkage could be established, only the gene of interest was analyzed. 
If linkage analysis was not informative and even a single gene could not be excluded, index patients from these families were analyzed for the genes involved in LQT1 and LOT2 as well as the genes involved in LOT5 and LOT6. Screening of the potassium channel encoding genes was performed to exclude involvement of compound heterozygosity in some severe cases of LQTS. The KCNJ2 gene, involved in Andersen syndrome and defined as LQT7 subtype, was not included in this study as no patients presented clinical features of facial abnormalities or clinodactily [14]. Involvement of the KCNJ2 gene has already been excluded in a large group of patients with an LQTS phenotype (Splawski 2001, personal communication).

Up to now the clinical diagnosis of LQTS was confirmed by the identification of a mutation in $91 \%$ of the familial cases (Table $1 ; 31 / 34$ families with $>1$ patient). The almost equal distribution of mutations between LQT1 and LQT2 ( $45 \%$ and $51 \%)$ is in line with frequencies reported in international studies ( $41 \%$ and $45 \%$ ) [15]. In only 3 families no mutation was identified. In 2 familial cases an involvement of one of the known LQTS genes was unlikely by linkage analysis indicating that an as yet unknown gene might be involved and one small family did not fulfill the Schwartz criteria (borderline QTc).

In the group of 43 single cases, 7 mutations $(7 / 43=16 \%)$ were identified but, none in the 10 cases with an acquired form of LQTS. With respect to the genetic results in the acquired form of LQTS, only a low frequency $(12 \%)$ of mutations has been reported in a large group of aLQTS patients [16]. Two identical KCNH2 mutations identified within the single cases, turned out to have a familial history and were counted as familial case. The SCN5A mutation (QTc $657 \mathrm{msec}$ ) was identified in a neonate with a ventricle septum defect (VSD) and a 2:1 atrioventricular (AV) block. The mother and grandmother were both carrier of the mutation but did not show any symptoms and had marginally prolonged QT values. Biophysical characterization of the SCN5A mutation revealed a sustained (non-inactivating) current as well as an increase in $\mathrm{Na}^{+}$ channel current. Both mechanisms are expected to delay the ventricular repolarization [17]. Four single cases with LQTS turned out to carry a very rare silent mutation of which the pathogenicity could not be established unequivocally. In our group, the number SCN5A mutations is low which can be expected since involvement of the LQT3 subtype is reported less frequently. Next to the identification of the pathogenic mutation in the index patients, follow-up investigations were performed in each family, leading to an additional number of 485 genotyped individuals, 227 of these individuals $(46.8 \%)$ were carriers of the familial gene defect. The mutation detection screening also provided additional information with respect to "de novo" mutations. Within the group tested, we were able to identify a "de novo" mutation or the origin of the mutation in the family in $3(8 \%)$ out of the 29 genetically defined LQTS families. 
Two "de novo" mutations were identified in the single cases as both parents did not carry the mutation. In each case of "de novo" mutations, non-paternity was excluded by using a set of autosomal polymorphic markers. It is obvious that, in a disorder like LQT syndrome, which seriously affects life expectancy, mutations will not be transmitted neutrally and disappear from the population. The fact that this disorder still exists means that, due to a mutation rate in the human genome of $10^{-5}$, new mutations will constantly emerge and when affecting germ cells, they may result in familial diseases (Vlietinck, personal communication). It also indicates that most families have their own "private" mutation and that a patient, without family history of syncope or other clinical features of LQTS, may be the first in line.

\section{Table 1. Overview of the genotyped LQTS population}

Total number of index patients that were analyzed $=87$

34 LQTS families with > 1 patient, positive family anamnesis, according to the Schwartz selection criteria

In 31 families the mutation was identified (91\%)

$14 \mathrm{KCNQ} 1$
- $\quad 16 \mathrm{KCNH2}$
- $\quad 1 \mathrm{SCN} 5 \mathrm{~A}$

In 7 single cases a mutation was identified $(16 \%)$

43 LQTS single cases with unknown or less obvious family anamnesis

- 3 KCNQ1

- $\quad 3 \mathrm{KCNH} 2$

- 1 SCN5A

10 acquired LQTS

no mutations were identified

"Wehrens et al. [17]

\section{Hypertrophic Cardiomyopathy}

Because of the large number of candidate genes involved in HCM and the limitations in selective clinical, gene-specific clues, we prefer to perform linkage analysis to identify and/or exclude candidate loci. An exception is the combined presence of HCM and Wolff-Parkinson-White syndrome (WPW) in a family with HCM and conduction defects, which directs to the gene, encoding the gamma2-subunit of the AMPactivated protein kinase (PRKAG2). In such a family a missense mutation was identified in the PRKAG2 gene. Until now, linkage analysis has only been successful in one family to map the genetic defect unambiguously. In this large family, marker and sequence analysis resulted in the identification of a novel mutation in the TPM1 gene [18, chapter 8-2). The majority of the HCM families were not suitable for linkage analysis, because of lack of living patients due to a high incidence of SCD or, of a limited number of participating healthy individuals who are essential for establishing a risk-haplotype. Therefore, the selection of genes to be tested by SSCP or DHPLC analysis was based on 
the frequency of mutations reported, and presumed malignancy as indicated by the occurrence of SCD. In 165 symptomatic index patients, diagnosed with HCM, a selected number of six exons, encoding part of the head domain of the $\beta$-myosin heavy chain (MYH7) were analyzed by SSCP analysis (chapter 8-1). Within these 6 exons, about $52 \%$ of all $\mathrm{MYH} 7$ mutations, and most of the malignant mutations have been reported. In a selected number of families (with a high risk for sudden death) the systematic screening was continued by DHPLC analysis of the TNNT2 gene and the TPM1 gene. Especially mutations in the TNNT2 gene are known for a limited or absent hypertrophy and a high frequency of SCD. In addition, all index cases have been analyzed exclusively for exon 25 of the MyBPC 3 gene by DHPLC analysis and a mutation specific amplification, because of the presence of a Dutch (founder) mutation which has been identified recently [19].

Until now, blood was collected from 183 patients. The vast majority had a family history of hypertrophic cardiomyopathy or related cardiac problems. In many cases, blood of affected relatives was available as well although, in general insufficient for linkage studies. These patients were tested for mutations as described above, although not all analyses were performed for the entire group. In $27 \%$ (50/183) of the patients a mutation could be identified (13 MYH7, 5 TNNT2, 2 TPM1 (chapter 8-2), 29 MyBPC3 and 1 PRKAG2. Mainly due to the founder mutation in the MyBPC 3 gene, this is a high score, given the limited protocol used. Leaving out the founder mutation, the percentage of mutations identified is still substantial (19\%) and higher than reported in literature with slightly different protocols. As compound heterozygous and homozygous mutations have been reported in the HCM population [20-23], we tested if compound heterozygosity occurred of the МуВРС 3 Dutch founder mutation, and either one of the mutations previously identified in the MYH7, TNNT2 or TPM1 genes, but this was not the case.

\section{Criteria for genetic pathogenicity}

The criteria for genetic pathogenicity are according to international recommendations and have been applied to the mutations which have been identified in the LQTS and the HCM population in this thesis [24-26]. Regarding the speed of new developments in genetic technology, the identification of genetic variants or mutations will not be a major problem in the near future. However, the interpretation of diagnostic value of the variations will become more challenging. For example the nucleotide substitutions which lead to an altered amino acid are not necessarily pathogenic and, on the other hand, apparently silent mutations might in fact be pathogenic. Whether a mutation will be pathogenic or not is often hard to predict.

Conclusions regarding the pathogenicity of the mutations which have been described in this thesis were based on: 
1) exclusion of the mutation within a representative control panel of at least 100 chromosomes;

2) co-segregation of the mutation in the family with the disease;

3) conservation of the involved amino acid within the protein domain in several species

4) the nature of the mutation (missense, nonsense, deletion, insertions etc.)

5) the localization of the mutation within specific functional protein domain

Sequences have to be compared with the tissue specific human reference sequence or tissue specific isoforms which can be obtained from the Genome Databases and National Center for Biotechnology Information (GDB and NCBI) available on the internet. The comparison of reference sequences has become easier due to the Human Genome Project and the increasing number of genome databases of various species which facilitates the investigation whether protein domains are highly conserved during evolution.

Besides pathogenic mutations, the genetic screening program has revealed a number of non coding SNPs, unclassified variants (UV) and amino acid polymorphisms (cSNP) that have been identified in either intronic or exonic sequences. The question is, whether these variants are completely neutral. One example is the Kozak sequence variant (ATG-5, c>t) in the KCNQ1 gene that has been identified in 3 index patients with LQTS (Chapter 3 ). This variant resides in the regulatory sequence and may affect translation and transcription processes, as has been demonstrated in an in-vitro transcription/translation system of the glycoprotein(GP)Ib-alpha gene. The presence of this specific Kozak variant exhibited an increased expression and more efficient translation of the mRNA $[27,28]$. Similar findings of pathogenic UVs have been reported within the BRCA1 and PKU genes, where silent mutations or even missense mutations resulted in alternative RNA splicing events or exon skipping [29, 30]. These UVs had affected specific short sequences that are present in exons and, either enhance or silence pre-mRNA splicing. Such specific short oligonucleotide sequences are termed exonic splicing enhancers (ESES) or exonic splicing silencers (ESSs) and play important roles in constitutive and alternative splicing [31, 32]. The alteration of correct splicing patterns by disruption of an exonic splicing enhancer may be a more frequent mechanism than previously thought. The aforementioned examples indicate that one should be careful in classifying these variants as polymorphisms as they may finally have a pathogenic effect. This implicates that the pathogenicity of mutations should be demonstrated in functional studies or in a suitable animal model to prove the disease causing effect of the mutation. Functional assays of novel mutations are necessary as they may provide novel insights and mechanisms, explaining the pathophysiology of this dangerous disease. However, within a diagnostic setting this is often difficult to realize. 


\section{Genotype-phenotype correlation}

\section{The Long QT syndrome}

One remarkable and important outcome of systematic genetic screening in the LQTS population is the possibility to distinguish genotype specific sub-phenotypes. Clinical evaluation of the genetic defined carriers has resulted in a gene specific trigger for cardiac events $[33,34,15]$. To date physicians can accelerate genetic analysis by highly accurate prediction (efficacy is $75 \%$ ) of the LQT gene involved which is based on the combined genotype-phenotype relationship (trigger and ECG phenotype)[35, 36]. In LQTS, missense mutations are predominantly involved (Table 4, chapter 2). Missense mutations normally result in stable mutated proteins which act by a dominant negative effect on the functional molecular structure as incorporated "poison proteins" (poison peptide hypothesis)[37]. However, frame shift mutations, resulting in premature stop codons, are less frequently involved in LQTS. It is generally accepted that truncated proteins result in unstable proteins or may lack functional domains and consequently fail to be incorporated into the ion channel complex [38]. Truncating mutations also may cause haploinsufficiency by nonsense mediated mRNA decay (NMD) or, if the mRNA is translated, truncated proteins can be quickly degraded by proteases (null-allele hypothesis) [39]. In LQTS, one mechanism for haploinsufficiency has been proposed to be due to ineffective post-translational modifications causing trafficking defects. However, the aforementioned hypotheses are often based on predictions without experimental evidence. Recently, functional testing of a novel missense mutation in the Per-Arnt-Sim (PAS) domain of $\mathrm{KCNH} 2$ has demonstrated that obviously, besides $\mathrm{C}$-terminal mutations, also an intracellular $\mathrm{N}$-terminal mutation may cause LQTS by deficient trafficking [40].

In young children, seizures may not always be recognized as a cardiac disease and the QT prolongation may go unrecognized on ECG [41]. During this study we repeatedly noticed that genetic analysis was requested in families with unexplained fainting or epilepsy as initial diagnosis. In these families the diagnosis had been mainly assumed in children carrying a mutation in the $\mathrm{KCNH} 2$ (LQT2) gene. This corroborates with the fact that two genes, $\mathrm{KCNQ} 2$ and $\mathrm{KCNQ} 3$, have been associated in Benign Familial Neonatal Epilepsy (BFNE). Both genes are expressed in the brain and belong to the same potassium channel family as the KCNQ1 gene and associated with LQT1 [42].

\section{Hypertrophic Cardiomyopathy}

In HCM a genotype-phenotype correlation is less obvious, except for $\mathrm{HCM}$ in relation to Wolff Parkinson White syndrome (WPW). In order to correlate a more specific genotype-phenotype relationship, additional genetic analysis of large populations of HCM patients will be necessary. 
In the $\beta$-myosin heavy chain gene ( $\mathrm{MYH7}$ ) many missense mutations have been associated with a malignant phenotype and a high incidence of SCD at a young age (age <40y).

Conflicting results have been reported for the Val606Met mutation in the MYH7 gene (chapter 8-1, this thesis) [43-45]. In case of a troponin-T (TNNT2) mutation the risk for SCD is earlier in lifetime (age <20y) while patients present less evident hypertrophy, making the clinical diagnosis a difficult issue. This early SCD is in line with our findings which is based on two individuals from two TNNT2 families, who died before the age of 15 , and one individual who experienced an aborted SCD at the age of fifteen.

On the other hand, mutations in the myosin binding protein $\mathrm{C}$ (MyBPC 3 ) have been associated with mild hypertrophy in young patients and a late onset of symptoms and good prognosis before the fifth decade of live $[46,47]$. The incidence of SCD in families with a MyBPC 3 mutation is less significant and it is still unknown and speculative what causes the late onset and the relative benign phenotype. Within the Dutch population of HCM index patients, one mutation is particularly prominent. The mutation introduces an insertion of a guanine at position 2373, codon 792 (2373insG) in exon 25 of the MyBPC 3 gene [48]. The mutation was present in $18 \%$ of the HCM population tested in our screening effort. The carriers mainly originated from the western part of the Netherlands. Analysis of cSNPs indicated that all carriers shared an identical haplotype which strongly supported the idea that this is a founder mutation and preliminary results have indicated that this specific mutation may have arisen originally in the western part of the Netherlands about 400-500 years ago [19]. Despite the increasing number of genetic studies and genotype-phenotype associations, useful information in HCM is limited. Most information is available for genes that were initially discovered and are now routinely screened. Recently, the human CRP3 gene was be added to the list of HCM causing genes [49]. The CRP3 gene encodes a muscle LIM protein (MLP) which is located within the $Z$ disk of the sarcomere. Initially, this gene was associated with dilated cardiomyopathy (DCM) in a murine MLP-gene knockout model [50] and recently, it has been demonstrated that a specific mutation was associated with DCM in humans as well, demonstrating that mutations within the same gene may be involved in two distinct phenotypes (HCM or DCM) [51].

\section{Incomplete penetrance}

The failure of a disorder to become manifest has also been recognized in LQTS and HCM. Both disorders may present with reduced penetrance and show variable expression. Factors that may influence the phenotype are age (late-onset) and gender. Mutations in the various genes and even mutations identified in an identical gene demonstrate a variable expression which also varied between family members with an identical mutation [52]. 
The incidence of LQTS is estimated at 1:15,000 in live births but by taking into account the low penetrance in some LQTS families, the mutation frequency might be even higher as these asymptomatic individuals may remain unrecognized during life time. Penetrance as low as $25 \%$ has been reported by Priori et al.[53]. Low penetrance implies that individuals with a genetic defect do not necessarily present a marked prolonged QTc interval or have clinical symptoms at all which may also complicate effective genetic linkage analysis. In literature it has been reported that among LQTS gene carriers $6 \%$ had a normal QT interval which may indicate that additional genetic components or environmental factors are involved in the clinical presentation of a mutation [54]. In case of low penetrance, LQTS indication is less sure and involvement of a known LQTS gene can only be reasonably excluded by screening all candidate genes. As an identical mutation may result in a phenotype, varying from mild to severe clinical features, other modifying factors (genes) must be involved and it has become an important issue to identify these modifier genes which could explain this clinical heterogeneity [5]. Founder mutations in LQTS, which are normally identified within "isolated" genetic populations, as for instance the KvLQT-Fin mutation, could provide an excellent group for studying the impact of these modifier genes in genotypedphenotype association study. Another explanation for low penetrance was based on the "nature of the mutation". One example is a C-terminal mutation in the KCNO1 gene that caused a form fruste LQTS with very mild clinical symptoms and low penetrance [55]. In LQTS truncating mutations and also missense mutations have been reported to cause haploinsuficiency by misprocessing of the (misfolded) protein from the nucleus into the membrane and are believed to be more benign in their expression [56]. Misprocessing or trafficking deficiency may be caused by several cellular processes as (de)phosphorylation defects, post-translational modifications, disturbed protein-assembly, targeting and anchoring defects to the specific subcellular domains.

As in LQTS families, variable expression and reduced penetrance has also been reported in HCM families and the spectrum of the disease is large (NYHA class I-IV). An example of variable expression and reduced penetrance is demonstrated in Figure 1, (chapter 8-2). On the other hand, high penetrance and a late disease onset has been reported in individuals with a $М y B P C 3$ mutation where the disease onset can even be expected until the fifth decade of life [57-59].

\section{Functional testing and pathogenesis}

Despite the enormous number of mutations identified in LQTS and HCM, the exact pathogenesis is still far from clear. The significance and contribution of many DNA variations remains to be investigated. Functional testing will be essential to support the initial genetically defined pathogenic mutation and may gain insight into the complex pathophysiology of these two malignant diseases. 
In LQTS functional testing is usually performed by testing the electrophysiological properties of wild type and/or mutated ion channels in heterologous expression systems often in combination with con-focal microscopy to indicate trafficking deficiency. Functional testing of ion channels has already provided valuable information on the effect of various mutations with respect to the dominant negative effect, loss or gain of function, altered (in)activation and gating behavior, as well as abnormal trafficking [60-63]. As the functional properties of the mutation observed in vitro may provide information regarding the pathogenicity of the mutation in vivo, functional tests are being performed in laboratories, specialized in electrophysiology (our collaboration with the Department of Physiology at the University of Antwerpen; Geelen et al. in preparation; Paulussen et al. in preparation) $[64,65]$.

Functional studies of mutated proteins have also demonstrated that the effect of the auxiliary subunits may be diverse [66]. Sodium $\beta$-subunits have been demonstrated to be multifunctional as they both modulate channel gating and regulate the level of channel expression at the plasma membrane. More recently, they have been shown to function as cell adhesion molecules in terms of interaction with the extracellular matrix, regulation of cell migration, cellular aggregation, and interaction with the cytoskeleton [67]. At present also protein-protein association studies of the membrane bound ion channel complex have been initiated to provide novel insights in channel function with respect to the requirement of a macromolecular signaling complex. [68]. The identification of such a KCNQ1-KCNE1 macromolecular complex has already provided a mechanism for sympathetic nervous system (SNS) modulation of the cardiac action potential duration through $\mathrm{I}_{\mathrm{ks}}$ current.

Functional testing of HCM mutations includes 'in vitro' and 'in vivo' experiments as well. For these purposes transgenic mice and rabbits, zebrafish, chicken embryos and other animal (knock-out) models are currently being used to get insight into the mechanism of hypertrophy [69, 70]. Because human tissue is largely unavailable, the unique tool of the murine myosin heavy chain transgenic model, has also enabled biophysical studies on the contractility of a sarcomeric mutation. Hopefully in the near future, also advanced molecular biological techniques like gene expression profiling and DNA micro-array analysis of human cardiac tissue will become available to reveal pathogenic pathways in HCM and LQTS at a level which can not be reached by classical studies alone.

\section{Gene specific therapy}

It has become clear that the unifying name of LQTS actually represents a variety of different diseases (LQT1-6) caused by mutations in ion channels that all lead to the same end result which is, prolonged ventricular repolarization. In LQTS medical treatment is indicated as the mortality rate of untreated patients with LQTS is in the 
range of $1-2 \%$ per year and increases to $50 \%$ within 10 -years [71, 72]. Recent data also favor treatment of asymptomatic patients if younger than 40-years of age at the time of diagnosis [72]. From the International LQTS Registry data indicated that in LQT1 patients, symptoms will become manifest at a younger age than in LQT2 and LQT3 carriers (age LQT1< LQT2< LQT3) [33]. This shows that in LQTS the initiation of medical treatment likely depends on the gene involved. To date genetic analysis has allowed medical treatment, based on the genotype of the individual at risk.

The risk for cardiac arrhythmias is mainly provoked by physical stress, except for LQT3 patients, and therefore intense stress should be avoided. Stress induced stimulation of the $\beta$-adrenergic receptors increases the heart rate and will influence the $I_{\mathrm{ks}}$ current. In patients who carry a KCNQ1 gene defect, the altered or diminished $I_{\mathrm{ks}}$ current provides a pathogenic substrate by an abnormal ventricular repolarization. The delayed repolarization increases the risk for Torsade de Pointes. Blockade of the $\beta$-adrenergic receptors with Class III anti-arrhythmic drugs decreases the heart rate, shortens the QT prolongation and neutralizes the risk factor. This mechanism probably explains why LQT1 patients have demonstrated a good respond to $\beta$-blockade therapy. Recently, a different response to $\beta$-blockade between LQT and LQT2 patients has been reported, providing a need for further clinical investigations on the effect of medical treatment in genotyped individuals $[73,74]$. In contrary, patients with an SCN5A (LQT3) mutation may benefit from medical treatment with a sodium channel blocker (Class IB antiarrhythmics). Since SCN5A gene defect carriers often present with slow heart rates, further decrease of the heart rate by $\beta$-blockade therapy could increase the risk for arrhythmia. Therefore in LQT3 patients additional cardiac pacing is warranted by an implantable cardioverter defibrillator (ICD). Recently, a gender specific response to medical treatment has been reported which has been observed in a group of genetically defined carriers [74, chapter 6]. In the Netherlands the general policy is to treat every gene carrier (Marcelis C, personal communication).

Thus far genetic analysis in HCM has been used to exclude individuals for being at risk and to advice gene carriers risk-avoiding behavior. The therapy in HCM is more aggressive and active recruitment is mainly initiated to protect carriers against life threatening arrhythmias by ICD implantation (chapter 7). Whether pharmacological treatment is an option remains to be established. Hereto, longitudinal investigations and serial non invasive measurements of the carriers (preferentially starting at a young age) should be initiated to follow the progression of the hypertrophy and to study the effect of long-term drug administration. 


\section{Ethical aspects of genetic testing in LQTS and HCM}

To date genetic analysis in families with LQTS and HCM has provided a diagnostic tool for identifying individuals at risk. However, adequate risk stratification is often complicated by low disease penetrance and the large clinical spectrum of both diseases (LQTS and HCM) and it might be questionable whether genetic testing should be promoted in all cases. If a genetic test is considered, genetic counseling of the patient is necessary. In inherited diseases genetic testing not only has consequences for the index patient but also for the family and can lead to a variety of psychological and social complications [75, 76]. In children, pre-symptomatic genetic testing can be performed when the result of the test has clinical implications in childhood. For LQTS families the answer is obvious and clinically affected individuals should be genotyped because this may have implications for the therapy and management $[77,51]$. Simultaneously, genetic identification is justified as these individuals may be protected against various QT prolonging drugs (chapter 2). In LQTS, in particular young children, are at risk for lethal arrhythmias and early diagnosis and treatment of yet asymptomatic children can be life saving.

The question whether genetic testing is justified in case of familial HCM, is difficult to answer as preventive measures have not been validated. The outcome of the genetic testing however, justifies intensive follow-up. Subsequently, dangerous arrhythmias may be prevented by the change of life style [78, 79]. Avoiding vigorous and competitive sports may result in a longer live span and a higher quality of life. For this reason we believe that genetic testing is justified. Of course testing must be supported by a multidisciplinary team trained in complex cardiovascular diseases and genetic counseling [80].

\section{Future aspects}

Despite the intensive screening of all LQTS candidate genes, no genetic abnormalities were detected in a few LQTS families suggesting that additional genes may contribute to the wide spectrum of the LQTS phenotype. Besides disease causing mutations, the identification of genetic modifier genes which might contribute to the phenotype as genetic risk factors will become challenging in the near future in both, LQTS and HCM. The increasing demand of genotype-phenotype correlation strongly supports the implementation of an International HCM registry similar to the International LQTS registry. Through combination of patient information world wide, enormous sets of data could be included which might lead to a more profound knowledge of the genotype-phenotype relationship.

The future of medicine will have a strong genetic component not only in the field of familial disease but also in the field of common diseases. Medicine will evolve from 
treating symptoms and disease to prevention. In order to reach this level, the genetic make-up of an individual as a whole has to be determined. This can be done 1) by large scale genotyping to study the constitution of and variants within genes or 2) at the genomic level by complete gene expression microarray analysis to study the activity of genes or 3) at the proteomics level. State-of-the-art bioinformatics and statistics have to be applied to deduce biological and medical information from rapidly accumulating, huge data-sets. Expectations of these technologies are high and this will lead first to improved classification of diseases by identifying specific gene expression profiles or genotypes for specific subgroups (predictive genetic signatures). Subgroups may not only differ in diagnosis, but also in prognosis or therapy, allowing adjustment of patient management at the individual level. Finally, detailed insight in the pathogenicity can be obtained by following gene expression patterns in relation to disease manifestations in time. Successes have already been reported in this field, predominantly in the classification of tumors [81]. With respect to LQT and HCM genomics can be expected to subclassify these disorders with respect to the gene involved and also to explain eventually reduced penetrance and individual differences in manifestation of the disease. A mutation is not a stand-alone feature, but is integrated in a biologically active organism. This also implies a shortcoming of current functional tests, which isolate the defect from the genetic background. Apart from disease associated variations in gene expression and genotypes, it can also be expected that at first sight less related processes may be involved and that also more general differences like metabolic activity, will play a role in developing the appropriate therapy. The true challenge of the future will be to transform all genetic and genomic data obtained in patient cohorts to treat patients and not diseases anymore. As many aspects are not known at this point this has to be a careful step by step process, despite all -omics hypes of the moment. 
Figure 1. Flow chart for the Long QT syndrome

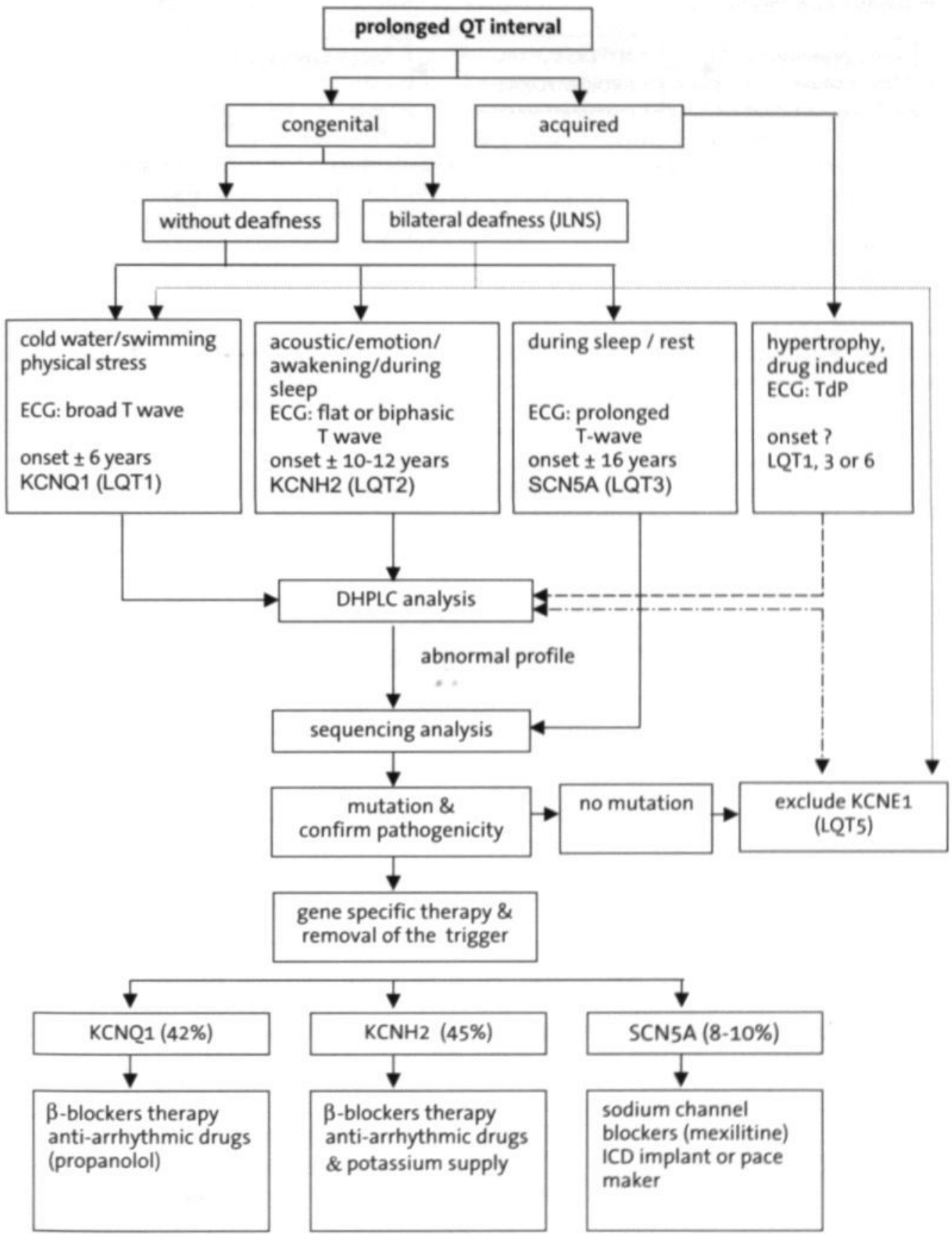


Figure 2. Flow chart for Familial Hypertrophic Cardiomyopathy

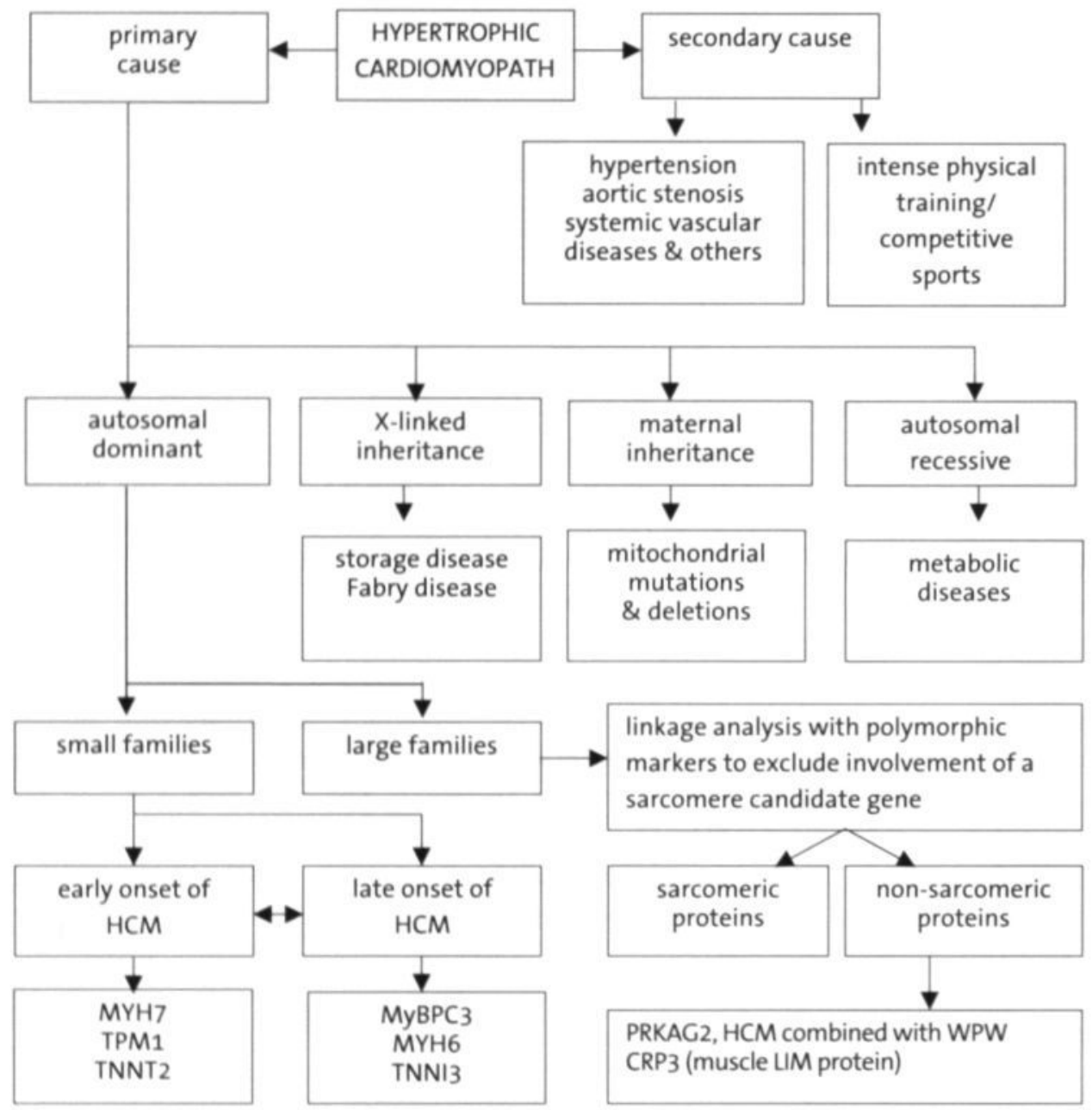

Preferred sequence of analysis:

1. $\mathrm{MyBPC}_{3}$ (founder mutation)

2. MYH7 (head domain by SSCP)

3. TNNT2 (complete by DHPLC)

4. TPM1 (complete by SSCP)

5. TNNI3 (complete by DHPLC)

6. ACTC (complete by sequencing)

7. Analysis of the remaining candidat
$\mathrm{ASH}+\mathrm{LVH}+$ late onset

$\mathrm{ASH}+\mathrm{LVH}+$ high incidence of SCD at age $<45 \mathrm{y}$ mild $\mathrm{ASH}+\mathrm{LVH}+$ high incidence of SCD at age $<25 \mathrm{Y}$

$\mathrm{ASH}+$ high incidence of SCD at age $<25 \mathrm{y}$

ASH, apical HCM, progressive LV diastolic dysfunction rare cause of $\mathrm{HCM}$

sarcomeric genes 


\section{References}

1. Russell MW, Dick M, Collins FS, Brody LC. KVLQT1 mutations in three families with familial or sporadic long QT syndrome. Hum Mol Genet. 1996;5:1319-1324.

2. Murray A, Donger C, Fenske C, Spillman I, Richard P, Dong YB, Neyroud N, Chevalier P, Denjoy I, Carter N, Syrris P, Afzal AR, Patton MA, Guicheney P, Jeffery S. Splicing mutations in KCNQ1: a mutation hot spot at codon 344 that produces in frame transcripts. Circulation. 1999;100:1077-1084.

3. Dausse E, Komajda M, Fetler L, Dubourg O, Dufour C, Carrier L, Wisnewsky C, Bercovici J, Hengstenberg C, al-Mahdawi S, et al. Familial hypertrophic cardiomyopathy. Microsatellite haplotyping and identification of a hot spot for mutations in the beta-myosin heavy chain gene. J Clin Invest. 1993;92:2807-2813.

4. Coviello DA, Maron BJ, Spirito P, Watkins H, Vosberg HP, Thierfelder L, Schoen FJ, Seidman JG, Seidman CE. Clinical features of hypertrophic cardiomyopathy caused by mutation of a "hot spot" in the alpha-tropomyosin gene. J Am Coll Cardiol. 1997;29:635-40.

5. Piippo K, Laitinen P, Swan H, Toivonen L, Viitasalo M, Pasternack M, Paavonen K, Chapman H, Wann KT, Hirvela E, Sajantila A, Kontula K. Homozygosity for a HERG potassium channel mutation causes a severe form of long QT syndrome: identification of an apparent founder mutation in the Finns. J Am Coll Cardiol. 2000;35:1919-1925.

6. Piippo K, Swan H, Pasternack M, Chapman H, Paavonen K, Viitasalo M, Toivonen L, Kontula K. A founder mutation of the potassium channel KCNQ1 in long QT syndrome: implications for estimation of disease prevalence and molecular diagnostics. J Am Coll Cardiol. 2001;37:562-568.

7. Orita M, Iwahana H, Kanazawa H, Hayashi K, Sekiya T. Detection of polymorphisms of human DNA by gel electrophoresis as single-strand conformation polymorphisms. Proc Natl Acad Sci. 1989;86:2766-2770.

8. Le Marechal C, Audrezet MP, Quere I, Raguenes O, Langonne S, Ferec C. Complete and rapid scanning of the cystic fibrosis transmembrane conductance regulator (CFTR) gene by denaturing high-performance liquid chromatography (D-HPLC): major implications for genetic counselling. Hum Genet. 2001;108:290-298.

9. Jongbloed R, Marcelis C, Velter C, Doevendans P, Geraedts J, Smeets H. DHPLC analysis of potassium ion channel genes in congenital long QT syndrome. Hum Mut. 2002;20:382-391.

10. van den Bosch BJ, de Coo RF, Scholte HR, Nijland JG, van Den Bogaard R, de Visser M, de DieSmulders CE, Smeets HJ. Mutation analysis of the entire mitochondrial genome using denaturing high performance liquid chromatograph. Nucleic Acids Res. 2000;28:E89.

11. Berthet M, Denjoy I, Donger C, Demay L, Hammoude H, Klug D, Schulze-Bahr E, Richard P, Funke H, Schwartz K, Coumel P, Hainque B, Guicheney P. C-terminal HERC mutations: the role of hypokalemia and a KCNQ1-associated mutation in cardiac event occurrence. Circulation. 1999;99:1464-1470.

12. Hoorntje T, Alders M, van Tintelen P, van der Lip K, Sreeram N, van der Wal A, Mannens M, Wilde A. Homozygous premature truncation of the HERG protein : the human HERG knockout. Circulation. 1999;100:1264-1267.

13. Lupoglazoff JM, Cheav T, Baroudi G, Berthet M, Denjoy I, Cauchemez B, Extramiana F, Chahine M, Guicheney P. Homozygous SCNSA mutation in long-QT syndrome with functional two-to-one atrioventricular block. Circ Res. 2001;89:E16-21.

14. Plaster NM, Tawil R, Tristani-Firouzi M, Canun S, Bendahhou S, Tsunoda A, Donaldson MR, lannaccone ST, Brunt E, Barohn R, Clark J, Deymeer F, George AL Jr, Fish FA, Hahn A, Nitu A, Ozdemir C, Serdaroglu P, Subramony SH, Wolfe G, Fu YH, Ptacek U. Mutations in Kir2.1 cause the developmental and episodic electrical phenotypes of Andersen's syndrome. Cell. 2001:105:511-519. 
15. Splawski I, Shen J, Timothy KW, Lehmann MH, Priori S, Robinson JL, Moss AJ, Schwartz PJ, Towbin JA, Vincent GM, Keating MT. Spectrum of mutations in long-QT syndrome genes. KVLQT1, HERG, SCN5A, KCNE1, and KCNE2. Circulation. 2000;102:1178-1185.

16. Paulussen A, Gilissen R, Aerssens J, Doevendans P, Verhaaselt P, Smeets $H$, Schulze Bahr E, haverkamp W, Breithart G, Cohen N, Armstrong M. Genetic susceptibility to acquired Long QT syndrome: the impact of Long QT genes and drug metabolising enzyme genes. Eur Heart J. 2003; Submitted.

17. Wehrens XHT, Rossenbacker T, Jongbloed RJ, Gewillig M, Heidbuchel H, Doevendans PA, Vos MA, Wellens HJJ, Kass R. A novel mutation L619F in the cardiac Na+ channel SCN5A associated with Long-QT syndrome (LQT3): a role for the I-II linker in activation gating. Hum Mut 2003;21:552.

18. Jongbloed RJ, Marcelis C, Doevendans PA, Schmeitz-Mulkens JM, van Dockum WG, Geraedts JP, Smeets HJ. Variable clinical manifestation of a novel missense mutation in the alpha-Tropomyosin (TPM1) gene in Familial Hypertrophic Cardiomyopathy. J Am Coll Card. 2003;41:981-986.

19. Alders $M$, Jongbloed $R$, Deelen $W$, van den Wijngaard $A$, Doevendans $P$, Ten Cate F, RegitzZagrosek V, Vosberg HP, van Langen I, Wilde A, Dooijes D, Mannens M. The 2373 insG mutation in the MYBPC 3 gene is a founder mutation which accounts for nearly one-fourth of the HCM cases in the Netherlands. Eur Heart J. 2003; Accepted for publication.

20. Richard P, Isnard R, Carrier L, Dubourg O, Donatien Y, Matthieu B, Bonne G, Gary F, Charron P, Hagege M, Komajda M, Schwartz K, Hainque B. Double heterzygosity for mutations in the betamyosin heavy chain and in the cardiac myosin binding protein $C$ genes in a family with hypertrophic cardiomyopathy. J Med Genet. 1999;36:542-545.

21. Ho CY, Lever HM, DeSanctis R, Farver CF, Seidman JG, Seidman CE. Homozygous mutation in cardiac Troponin T. Implications for Hypertrophic Cardiomyopathy. Circulation. 2000;102:1950-1955.

22. Richard P, Charron P, Leclercq C, Ledeuil C, carrier L, Dubourg O, Desnos M, Bouhour JB, Schwartz K, Daubert JC, Komajda M, Hainque B. Homozygotes for a R869G mutation in the beta-myosin heavy chain gene have a severe form of familial hypertrophic cardiomyopathy. J Mol Cell Cardiol. 2000;32:1575-1583.

23. Richard P, Charron P, Carrier L, Ledeuil L, Dubourg O, Desnos M. Distribution of disease genes in 102 genotyped families with hypertrophic cardiomyopathy. Circulation. 2001;104 (Suppl):II-521.

24. Cotton RG, Scriver CR. Proof of "Disease Causing"Mutation. Human Mutation. 1998;12:1-3.

25. den Dunnen JT, Antonarakis SE. Mutation nomenclature extensions and suggestions to describe complex mutations: a discussion. Hum Mutat. 2000;15:7-12.

26. Hamosh A, Scott AF, Amberger J, Valle D, McKusick VA. Online Mendelian Inheritance in Man (OMIM). Hum Mutat. 2000;15:57-61.

27. Afshar-Kharghan V, Li CQ, Khoshnevis-AsI M, Lopez JA. Kozak sequence polymorphism of the glycoprotein (GP) Ibalpha gene is a major determinant of the plasma membran levels of the platelet GP Ib-IX-V complex. Blood. 1999;94:186-191.

28. Meisel C, Afshar-Kharghan V, Cascorbi I, Laule M, Stangle V, Felix S, Baumann G, Lopez AL, Roots I, Stangle K. Role of Kozak sequence polymorphism of platelet glycoprotein Ib-alpha as a risk factor for coronary artery disease and catheter interventions. J Am Coll Cardiol. 2001;38:1023-1027.

29. Fackenthal JD, Cartegni L, Krainer AR, Olopade OI. BRCA2 T2722R is a deleterious allele that causes exon skipping. Am J Hum Genet. 2002;71:625-631.

30. Chao HK, Hsiao KJ, Su TS. A silent mutation induces exon skipping in the phenylalanine hydroxylase gene in phenylketonuria. Hum Genet. 2001;108:14-19.

31. Blencowe BJ. Exonic splicing enhancers: mechanism of action, diversity and role in human genetic diseases. Trends Biochem Sci. 2000;25:106-110.

32. Lam BJ, Hertel KJ. A general role for splicing enhancers in exon definition. RNA. 2002;8:1233-1241.

33. Wilde AA, Jongbloed RJ, Doevendans PA, Duren DR, Hauer RN, van Langen IM, van Tintelen JP, Smeets HJ, Meyer H, Geelen JL. Auditory stimuli as a trigger for arrhythmic events differentiate 
HERG-related (LQTS2) patients from KVLQT1-related patients (LQTS1). J Am Coll Cardiol. 1999:33:327-332.

34. Conrath CE, Jongbloed RJE, van Langen IM, van Tintelen JP, Hauer RNW, Robles de Medina EO, Düren DR, Hoorntje TM, Lubbers U, Doevendans PAFM, Mannens MAMM, Geelen JLMC, Smeets HJM, Wilde AAM. Gene-specific distribution of cardiac events in LQTS1 and LQTS2. Cardiologie. 1999;6:254-259.

35. Wilde AAM, Roden DM. Predicting the Long-QT Genotype From Clinical Data. From Sense to Science. Circulation. 2000;102:2796-2798.

36. van Langen IM, Birnie E, Alders M, Jongbloed RJ, Le Marec $H$, Wilde AAM. The use of genotypephenotype correlations in mutation anal for the long QT syndrome. J Med Genet. 2003:40:141-145.

37. Bonne G, Carrier L, Richard P, Hainque B, Schwartz K. Familial hypertrophic cardiomyopathy: from mutations to functional defects. Circ Res. 1998;83:580-593.

38. Kupershmidt S, Yang T, Chanthaphaychith S, Wang Z, Towbin JA, Roden DM. Defective human Ether-a-go-go-related gene trafficking linked to an endoplasmic reticulum retention signal in the C terminus. J Biol Chem. 2002;277:27442-27448.

39. Byers PH. Killing the messenger: new insights into nonsense mediated mRNA decay. J. Clin. Invest. 2002;109:3-6.

40. Paulussen A, Raes A, Matthijs G, Snyders DJ, Cohen N, Aerssens J. A novel mutation (T65P) in the PAS domain of the human potassium channel HERG results in the long QT syndrome by trafficking deficiency. J Biol Chem. 2002;227:48610-48616.

41. Pacia SV, Devinsky O, Luciano DJ, Vazquez B. The prolonged QT syndrome presenting as epilepsy: a report of two cases and literature review. Neurology. 1994;44.

42. Charlier C, Singh NA, Ryan SG, Lewis TB, Reus BE, Leach RJ, Leppert M. A pore mutation in a novel KQT-like potassium channel gene in an idiopathic epilepsy family. Nat Genet. 1998;18:53-55.

43. Abchee A, Marian AJ. Prognostic significance of beta-myosin heavy chain mutations is reflective of their hypertrophic expressivity in patients with hypertrophic cardiomyopathy. I Investig Med. 1997:Apr:191-196.

44. Semsarian C, Yu B, Ryce C, Lawrence C, Washington H, Trent RJ. Sudden cardiac death in familial hypertrophic cardiomyopathy: are "benign" mutations really benign? Pathology. 1997:29:305-308.

45. Havndrup O, Bundgaard H, Andersen PS, Larsen LA, Vuust J, Kjeldsen K, Christiansen M. The Val606Met mutation in the cardiac beta-myosin heavy chain gene in patients with familial hypertrophic cardiomyopathy is associated with a high risk of sudden death at young age. Am J Cardiol. 2001;87:1315-1317.

46. Niimura H, Patton KK, MCKenna WJ, Soults J, Maron BJ, Seidman JG, Seidman CE. Mutations in the gene for cardiac myosin-binding protein $\mathrm{C}$ and late-onset familial hypertrophic cardiomyopathy. N Engl J Med. 1998;338:1248-1257.

47. Charron P, Dubourg O, Desnos M, Bennaceur M, Carrier L, Camproux AC, Isnard R, Hagege A, Langlard JM, Bonne G, Richard P, Hainque B, Bouhour JB, Schwartz K, Komajda M. Clinical features and prognostic implications of familial hypertrophic cardiomyopathy related to cardiac-myosin binding protein C gene. Circulation. 1998;97:2230-2236.

48. Moolman JA, Reith S, Uhl K, Bailey S, Gautel M, Jeschke B, Fischer C, Ochs J, McKenna WJ, Klues H, Vosberg HP. Newly Created Splice Donor Site in Exon 25 of the MyBP-C gene is responsible for inherited Hypertrophic Cardiomyopathy With Incomplete Disease Penetrance. Circulation. 2000;101:1396-402A.

49. Geier C, Perrot A, Ozcelik C, Binner P, Counsell D, Hoffmann K, Pilz B, Martinak Y, Gehmlich K, van der Ven P, Furst D, Vornwald A, von Hodenberg E, Nurnberg P, Scheffold T, Dietz R, Osterziel K. Mutations in the human muscle UM protein gene in families with hypertrophic cardiomyopathy. Circulation. 2003;107:1390-1395. 
50. Arber S, Hunter JJ, Ross J Jr, Hongo M, Sansig G, Borg J, Perriard JC, Chien KR, Caroni P. MLPdeficient mice exhibit a disrubtion of cardiac cytoachitectural organization, dilated cardiomyopathy, and heart failure. Cell. 1997;88:393-403.

51. Knoll R, Hoshijima M, Hoffman HM, Person V, Lorenzen-Schmidt I, Bang ML, Hayashi T, Shiga N, Yasukawa H, Schaper W, McKenna W, Yokoyama M, Schork NJ, Omens JH, McCulloch AD, Kimura A, Gregorio CC, Poller W, Schaper J, Schultheiss HP, Chien KR. The cardiac mechanical stretch sensor machinery involves a $\mathrm{Z}$ disc complex that is defective in a subset of human dilated cardiomyopathy. Cell. 2003;111: 943-955.

52. Charron P, Carrier L, Dubourg O, Tesson F, Desnos M, Richard P, et al. Penetrance of familial hypertrophic cardiomyopathy. Genet Couns. 1997;8:107-114.

53. Priori SG, Napolitano C, Schwartz PJ. Low penetrance in the long-QT syndrome: clinical impact. Circulation. 1999;99:529-33.

54. Vincent $\mathrm{GM}$, Timothy KW, Leppert M, Keating MT. The spectrum of symptoms and QT intervals in carriers of the gene for the long QT syndrome. N Engl J Med. 1992;327:846-852.

55. Donger C, Denjoy I, Berthet M, Neyroud N, Cruaud C, Bennaceur M, Chivoret G, Schwartz K, Coumel P, Guicheney P. KVLQT1 C-Terminal Missense Mutation Causes a Forme Fruste Long QTSyndrome. Circulation. 1997;96:2778-2781.

56. Moss AJ, Zareba W, Kaufman ES, Gartman E, Peterson DR, Benhorin J, Towbin JA, Keating MT, Priori SG, Schwartz PJ, Vincent GM, Robinson JL, Andrews ML, Feng C, Hall WJ, Medina A, Zhang L, Wang Z. Increased risk of arrhythmic events in long-QT syndrome with mutations in the pore region of the human ether-a-go-go-related gene potassium channel. Circulation. 2002;105: 794-799.

57. Niimura H, Bachinski LL, Sangwatanaroj S, Watkins H, Chudley AE, McKenna W, Kristinsson A, Roberts R, Sole M, Maron BJ, Seiman JG, Seidman CE. Mutations in the gene for cardiac myosinbinding protein C and late-onset familial hypertrophic cardiomyopathy. N Engl J Med. 1998;338:1248-1257.

58. Maron BJ, Niimura H, Casey SA, Soper MK, Wright GB, Seiman JG, Seiman CE. Development of left ventricular hypertrophy in adults in hypertrophic cardiomyopathy caused by myosin-binding protein C gene mutations. J Am Coll Cardiol. 2001;38:315-321.

59. Niimura H, Patton KK, McKenna WJ, Soults J, Maron BJ, Seidman JG, Seidman CE. Sarcomeric protein gene mutations in hypertrophic cardiomyopathy of the elderly. Circulation. 2002;105:446-451.

60. Veldkamp MW, Viswanathan PC, Bezzina C, Baartscheer A, Wilde AA, Balser JR. Two distinct congenital arrhythmias evoked by a multidysfunctional $\mathrm{Na}(+)$ channel. Circ Res. 2000;86:E91-97.

61. Sanguinetti MC. Maximal function of minimal K+ channel subunits. Trends Pharmacol Sci. 2000;21:199-201.

62. Furutani M, Trudeau MC, Hagiwara N, Seki A, Gong Q, Zhou Z, Imamura S, Nagashima H, Kasanuki H, Takao A, Momma K, January CT, Robertson GA, Matsuoka R. Novel mechanism associated with an inherited cardiac arrhythmia: defective protein trafficking by the mutant HERG (G601S) potassium channel. Circulation. 1999;99:2290-2294.

63. Ficker E, Thomas D, Viswanathan PC, Dennis AT, Priori SG, Napolitano C, Memmi M, Wible BA, Kaufman ES, lyengar S, Schwartz PJ, Rudy Y, Brown AMThomas D, Viswanathan PC, Dennis AT, Priori SG, Napolitano C, Memmi M, Wible BA, Kaufman ES, lyengar S, Schwartz PJ, Rudy Y, Brown AM. Novel characteristics of a misprocessed mutant HERG channel linked to hereditary long QT syndrome. Am J Physiol Heart Circ Physiol. 2000;279:H1748-1756.

64. Geelen JLMC, Raes A, Jongbloed RIE, Geraedts JPM, Snyders DJ. Temperature-sensitive rescue of a dominant negative HERG-LQT2 mutant. Circ Res. In preparation.

65. Paulussen AD, Jongbloed RJE, Raes A, Snyders DJ, Smeets H, Aerssens J. Expression of two LQTS Cterminal mutations in $\mathrm{KCNH} 2$ indicate trafficking defects. Cardiovasc Res. In preparation.

66. Attali B. Human congenital long QT syndrome: more than previuosly thought. Trends in Pharmacological Sciences. 2002;23:249-251. 
67. Isom LL. Sodium channel beta subunits: anything but auxiliary. Neuroscientist. 2001;7:42-54

68. Marx SO, Whisler SL, Clericuzio C, Keating M. Requirement of a macromolecular signaling complex for beta adrenergic receptor modulation of the KCNQ1-KCNE1 potassium channel. Science. 2002;295:496-499.

69. Arad M, Seidman JG, Seidman CE. Phenotypic diversity in hypertrophic cardiomyopathy. Hum Mol Genet. 2002;11:2499-2506.

70. Fatkin D, Graham RM. Molecular mechanisms of inherited cardiomyopathies. Physiol review. 2002;82:945-980.

71. Wehrens XHT, Vos MA, Wilde AAM. Cardiovascular Genetics for Clinicians. Doevendans PA, Wilde AAM (eds). Dordrecht, Netherlands: Kluwer Academic Publishers. 2001.

72. Khan IA. Long QT syndrome: Diagnosis and management. Am Heart J. 2002;143:7-14.

73. Shimizu W, Tanabe Y, Aiba T, Inagaki M, Kurita T, Suyama K, Nagaya N, Taguchi A, Aihara N, Sunagawa K, Nakamura K, Ohe T, Towbin JA, Priori SG, Kamakura S. Differential effects of betablockade on dispersion of repolarization in the absence and presence of sympathetic stimulation between the LQT1 and LQT2 forms of congenital long QT syndrome. J Am Coll Cardiol. 2002;39:1984-1991.

74. Conrath CE, Wilde AA, Jongbloed RJ, Alders M, van Langen IM, van Tintelen JP, Doevendans PA, Opthof T. Gender differences in the long QT syndrome: effects of beta-adrenoceptor blockade. Cardiovasc Res. 2002;53:770-776.

75. Van Langen IM, van Tintelen JP. Klinisch-genetisch onderzoek in de cardiologie. Deel 1. Cardiologie. 1999;6:13-21.

76. Keller D, Carrier L, Schwartz L. Genetics of familial cardiomyopathies and arrhythmias. Swiss Med Wkly. 2002;132:401-407.

77. Van Langen IM, van Tintelen JP. Klinisch-genetisch onderzoek in de cardiologie. Deel 2. Cardiologie. 1999;6:62-69.

78. Wilde AAM, van Langen IM, Mannens MMAM, Doevendans PAFM, van Veldhuisen DJ, van Tintelen JP, Smeets H. Hypertrofische cardiomyopathie; bij wie en waarom genetisch onderzoek. Cardiologie. 1998;5:489-491.

79. Wilde AAM, van Langen IM, van Tintélen JP, Hauer RNW. Presymptomatisch onderzoek na plotselinge hartdood in de familie. Ned Tijdschr Geneeskd. 1999;143:1643-1648.

80. Ten Kroode HF, van Langen IM, Hendriks KS, van Tintelen JP, Grosfeld FJ, Wilde AA. Het lang-QTintervalsyndroom en erfelijkheidsonderzoek: psychische reacties in drie generaties van een familie. Ned tijdsch Geneeskd. 2000;144:995-999.

81. Van 't Veer U, Dai H, van de Vijver MJ, He YD, Hart AA, Mao M, Peterse HL, van der Kooy K, Marton MJ, Witteveen AT, Schreiber GJ, Kerkhoven RM, Roberts C, Linsley PS, Bernards R, Friend SH. Gene expression profiling predicts clinical uotcome of breast cancer. Nature. 2002;415:530-536. 



\section{Summary}

In the last decade Genetics has become of major importance in medicine and medical sciences. In Cardiology, the term Cardiogenetics has been introduced to indicate this new field of health care in cardiovascular disease. The genetics revolution has been initiated by the rapid advance in knowledge on genomes of humans and all kind of model organisms. This has been corroborated by a rapid progress in molecular biological and genomics technology, which has among others led to the identification of genes involved in congenital heart diseases and primairy cardiac arrhythmias, which is the topic of this thesis. Alterations (mutations) in these genes are a cause of sudden death at a young age. Many investigations have been performed by us and others in particular in congenital long QT syndrome and the hereditary disease associated with an enlarged cardiac left chamber (hypertrophic cardiomyopathy). Especially in LQTS the presence of a disease causing (pathogenic) mutation and the clinical presentation within the family, has provided important breakthroughs in understanding the origin of this inherited disease, the clinical features and the medical treatment.

The first part of this thesis covers the Long QT syndrome (LQTS). Chapter 2 reviews clinical, genetic, functional aspects and medical treatment of LQTS and the ion channel genes and proteins involved. The name of the disorder is derived from a characteristic lengthening of the QT time interval. In LQTS the electric instability is caused by an abnormal cardiac repolarization thereby creating a substrate for (fatal) cardiac arrhythmia named Torsade de Pointes (TdP). Due to these ventricular arrhythmias, carriers of the genetic defect may repeatedly suffer from syncope and seizures and may in some instances lead to sudden cardiac death. LQTS is a predominantly autosomal dominant disorder and at this point we distinguish 7 subtypes, involving cardiac potassium channel genes (KCNQ1/KvLQT1-LQT1, KCNH2/HERG-LQT2) and their co-factors (KCNE1-LQT5, KCNE12-LQT6), a cardiac sodium channel gene (SCN5A-LQT3) and an ankyrin gene (AnkB-LQT4). Mutations in these genes can alter protein function in a dominant negative way and cause malfunctioning ion channels. As a result a critical situation is created that may cause an electric instability in the heart. In addition to the genetic form an acquired or medication induced form of LQTS exists as well.

Chapter 3 describes the results of a partial genetic screening protocol to unravel the genetic causes of LQTS in the Dutch LQTS population. The KCNQ1 and HERG (KCNH2) genes were tested by Single Stranded Conformation Polymorphism (SSCP) analysis, followed by sequence analysis of shifted fragments. A disease causing mutation was identified in $58 \%$ of the Dutch families and a large number of individuals at risk were genotyped. This screening protocol was extended (Chapter 4) to all potassium channel genes and a new more sensitive, faster and automated approach was applied by incorporating DHPLC analysis. 
Subsequently, genetic screening was continued and extended by analyzing the entire encoding region of the genes. With this protocol $91 \%$ of the familial cases of LQTS and in $16 \%$ of the single cases the disease causing mutation could be clarified and followup investigations in families could be offered. We conclude that our approach is highly efficient and rapid in detecting almost all familial LQTS mutations.

Chapter 5 deals with genotype-phenotype correlations. LQTS patients have an increased risk for ventricular arrhythmias and these events are triggered by physical stress, swimming or diving, a loud noise or sleep. Our investigations showed that these triggers were highly gene-specific. The highest correlation was shown for KCNH2/HERG mutations and a load noise or acoustic trigger (5-1), but also a high association between subtype LQT1 and cold water (swimming, diving) was observed, while other triggers were present in both subtypes (5-2). The correlation of the trigger and the various subtypes in LQTS has been extremely valuable in selecting the genes most likely involved for screening and has increased the speed, with which the genetic causes can be detected, considerably. This is of major importance in a fatal, but treatable disorder like LQTS.

In Chapter 6 the initial results of B-blockade therapy in a group of genetically defined carriers of subtype LQT1 and LQT2 are presented. Our results indicate a significant decrease in clinical symptoms in the group of LQT1 patients (KCNQ1). Within the group of LQT2 patients the decrease in complaints, as a result of the B-blockade therapy, was less significant. A gender difference was also noticed with respect to the response to medical treatment in carriers of a LQT1 mutation. This phenomenon was not observed in the carriers with a LQT2 $(\mathrm{KCNH} 2)$ mutation.

The second part of this thesis deals with the congenital form or primary form of hypertrophic cardiomyopathy (HCM). Chapter 7 discusses the clinical and genetic characteristics of HCM and the genotype-phenotype correlation and treatment. Congenital or familial HCM (FHC) is inherited as an autosomal dominant trait and is both genetically and clinically extremely heterogeneous. At present, mutations in twelve genes have been reported to be associated with the disease. Ten out of these twelve genes encode for sarcomeric proteins which are involved in generating the force and the contractility of the cardiac muscle. Alterations in these proteins may finally result in a decreased muscle contractility and it has been proposed that a mechanism is initiated to compensate the loss of force generating power which promotes the local hypertrophy in the left chamber and in particular the septum. Until now therapeutic intervention is limited and prophylactic therapy is mainly used to minimize the progression of the hypertrophy and to prevent life threatening arrhythmias. This can be achieved by changing the life-style and by implementing medical therapy or an implantable defibrillator (ICD) to prevent arrhythmias. 
Additionally, in case of a conduction block the implantation of a pacemaker might be considered. In addition to the inherited form many other, far more common causes of cardiac hypertrophy like hypertension, coronary vascular diseases or intensive sports (sports heart), exist.

Based on the frequency of mutations that had been reported previously genetic screening has been initiated in the B-myosin-heavy-chain gene (MYH7) in a number of 60 index patients all diagnosed for familial HCM and with a high risk for sudden death (Chapter 8). The result of the genetic analysis can be valuable in identifying gene carriers in particular in those families that are associated with a malignant form of HCM. The protocol was based on SSCP analysis, followed by sequence analysis. The added value of large families, in which linkage analysis can be performed is shown as well (8-2). Linkage analysis pointed at the involvement of the $\alpha$-tropomyosin (TPM1) gene in a single large family, which was confirmed by the presence of a pathogenic mutation in the TPM1 gene. The power and the success rate of linkage analysis largely depends on the number of individuals, affected and non-affected members, available.

In Chapter 9 an update will be presented of our own actual data and the data from literature, together with prospective of the future. Genetic screening in families with LQTS has been highly successful and has resulted in the identification of a causative genetic defect in a large number of families and in further classification of the various subtypes. Based on genotype-phenotype correlations a straightforward gene-specific screening protocol has been developed. This offers the possibility of early identification and pre-symptomatic diagnostics and if possible lifesaving gene-specific treatment. Additionally, non carriers can be reassured and dismissed of further medical treatment. In HCM, however, despite extensive research an accurate genotypephenotype correlation is only in rare cases possible. This complicates the selection of candidate gene for diagnostic genetic screening. In the Dutch HCM population the genetic screening effort now has resulted in identifying the disease causing mutation in about $30 \%$ of the families. Again predictive testing is possible in the families of these patients, but given the limited therapeutic options is less straightforward. In the group of patients from families with SCD, gene carriers patients may benefit from a more aggressive (applied) intervention. In addition to this, routine yearly screening will be advised to follow the cardiac hypertrophy. Also prophylactic medical treatment can be initiated to delay the cardiac hypertrophy and to guaranty a long lasting normal heart function.

Genetics has taken a strong position in genetic cardiac disease in the last couple of years and further technical improvement will make genetic testing the first step of the diagnostic protocol. 
Especially, as genes can cause many phenotypes ( $\mathrm{HCM}$, dilated cardiomyopathy [DCM]) and phenotypes can be caused by a variety of genes (at least 12 genes in HCM), the solution has to come either from dedicated protocols or from largely increased mutation detection capacity. We hope to achieve the first by gene expression profiling of affected and unaffected tissue and resolving a gene-specific profile or signature. On the other hand given the limitations in getting access to affected tissues, up-scaling of mutation screening programs, the second option, will be most promising and a variety of technologies, including CHIPs, can be applied. One has to keep in mind however that the amount of data produced does not keep pace with the interpretation of the data, which will be the challenge for genetic service in the years to come. 


\section{Samenvatting}

De laatste decennia heeft de genetica een belangrijke plaats ingenomen binnen het geheel van de medische zorg en wetenschap. De term Cardiogenetica reflecteert het nieuwe samenwerkingverband op het gebied van de gezondheidszorg van cardiovasculaire aandoeningen. Deze stormachtige ontwikkelingen op het gebied van de genetica zijn vooral te danken aan de revolutionair toegenomen kennis van het genoom van mens en andere species, als resultaat van het humane genoomproject, en aan de snel voortschrijdende ontwikkelingen in moleculair biologische technieken. Deze technieken hebben ertoe geleid dat genen konden worden geïdentificeerd die betrokken waren bij een aantal erfelijke vormen van primaire vormen van hartritmestoornissen en hartspieraandoeningen. Dit proefschrift gaat over de genen en gendefecten bij het aangeboren lange QT syndroom en bij aangeboren (familiaire) spierafwijking welke resulteert in een verdikking van de linker hartkamer (hypertrofische cardiomyopatie). Kleine veranderingen (mutaties) in deze genen kunnen leiden tot plotse hartdood op jonge leeftijd. Bij het lange QT syndroom heeft het onderzoek van genen en gendefecten in relatie tot het klinisch beeld in LQT families geleid tot belangrijke nieuwe inzichten in de oorsprong van deze erfelijke aandoening, de klinische kenmerken en de toegepaste behandelingsmethode.

Het eerste gedeelte van dit proefschrift behandelt het aangeboren lange QT syndroom (LQTS). In Hoofdstuk 2 wordt een overzicht gegeven van de klinische, genetische en functionele aspecten en de medische behandeling van dit syndroom. De naam lange QT syndroom is gebaseerd op de karakteristieke verlenging van het QT tijdsinterval, welke duidt op een abnormale repolarisatie in het hart. Deze abnormale repolarisatie veroorzaakt een elektrische instabiliteit, waardoor er een kritieke situatie ontstaat die kan leiden tot een specifieke gevaarlijke hartritmestoornis genaamd Torsade de Pointes (TdP). Bij dragers van het genetisch defect kunnen ritmestoornissen reeds op jonge leeftijd de oorzaak zijn van herhaaldelijk wegraken en bewustzijnsverlies (absences en syncopes) en in het uiterste geval zelfs leiden tot een plotse hartstilstand met de dood als gevolg. LQTS erft voornamelijk autosomaal dominant over en er zijn momenteel 7 subtypen bekend. De betrokken genen coderen voor hartspecifieke kaliumkanalen (KCNQ1/KvLQT1-LQT1, KCNH2/HERG-LQT2, KCNJ2-LQT7) en hun cofactoren (KCNE1-LQT5, KCNE12-LQT6), een hartspecifiek natrium kanaal (SCN5A-LQT3) en een ankyrin (AnkB-LQT4). Mutaties in deze genen veranderen de eiwitfunctie in het algemeen via een dominant-negatief mechanisme met als resultaat slecht functionerende ionkanalen en elektrische instabiliteit. Naast de erfelijke vorm van LQTS bestaat ook nog een verworven of medicatie geïnduceerde vorm van LQTS. 
Hoofdstuk 3 geeft een overzicht van de resultaten van het eerste onderzoek van een deel van de betrokken genen in een aantal Nederlandse families. Van de KCNQ1- en $\mathrm{KCNH} 2$ (HERG)- genen werden de gebieden, welke coderen voor de membraangebonden delen van het eiwit (S1-S6), geanalyseerd met behulp van de "Single Stranded Conformation Polymorphism" (SSCP) analyse methode. In $58 \%$ van de gevallen werd een mutatie aangetoond. Het genetisch onderzoek werd uitgebreid (Hoofstuk 4) middels de volledige analyse van deze twee genen met de DHPLCtechniek. Dit is een relatief nieuwe geautomatiseerde methode voor mutatiedetectie, die sneller en gevoeliger is dan de SSCP methode. Hiermee kon uiteindelijk in $91 \%$ van de onderzochte LQTS families en in $16 \%$ van de losse personen met LQT een ziekte veroorzakende mutatie worden aangetoond. Via onderzoek in de families konden gendragers vroegtijdig worden geïdentificeerd.

Hoofdstuk 5 gaat in op de relatie tussen genotype en fenotype. Patiënten met LQTS hebben een verhoogd risico op ventriculaire ritmestoornissen. Factoren (triggers) die deze ritmestoornissen kunnen uitlokken zijn o.a. fysieke inspanning (intensief sporten), stress situaties, zwemmen of duiken, harde geluiden, maar ook slaap. Uit het genetisch onderzoek is gebleken dat deze triggers genspecifiek zijn. Een zeer duidelijk verband werd aangetoond tussen mutaties in het KCNH2/HERG gen en een plotseling hard geluid (5-1) en in iets mindere mate tussen KCNQ1-mutaties en koud water (zwemmen, duiken). Andere triggers (inspanning, emotie) konden beide vormen van LQTS veroorzaken (5-2). Een causaal verband tussen de trigger en de verschillende vormen van LQTS is zeer belangrijk om het meest waarschijnlijke kandidaat-gen te identificeren, zodat zeer snel de genetische oorzaak kan worden opgespoord. Dit is voor een levensbedreigende, maar behandelbare aandoening als LQTS uiterst relevant.

Hoofdstuk 6 beschrijft het eerste onderzoek van een groep genetisch gedefinieerde LQTS1 en LQTS2 patiënten voor en tijdens de behandeling met een B-adrenoceptor blokkade. De eerste resultaten duiden op een duidelijke vermindering van de klinische klachten bij de groep patiënten met een gendefect in het KCNQ1/KvLQT1 (LQT1) gen. Bij de groep patiënten met een genetisch defect in het KCNH2/HERG (LQT2) gen was deze afname echter minder duidelijk. Tevens werd geconstateerd dat de QTC tijd bij de mannelijke LQT1 gendragers aanzienlijk korter werd dan bij vrouwelijke LQT1gendragers. Dit verschijnsel werd niet waargenomen bij de LQT2 gendragers.

Het tweede gedeelte van dit proefschrift gaat in op de erfelijke ofwel primaire vorm van hypertrofische cardiomyopatie (HCM). Hoofdstuk 7 beschrijft de klinische en erfelijke kenmerken van $\mathrm{HCM}$, de genotype-fenotype correlatie en de huidige medische behandeling. De erfelijke of familiaire vorm van HCM (FHC) erft autosomaal dominant over en de ziekte vertoont zowel klinisch als genetisch een zeer heterogeen beeld. 
Inmiddels zijn twaalf genen beschreven die verantwoordelijk zijn voor het ontstaan van de aandoening. Tien van deze genen coderen voor eiwitten die verantwoordelijk zijn voor de contractiele eigenschappen van de hartspier. Mutaties in deze genen kunnen resulteren in een de verminderde contractie(kracht) van de hartspier en men vermoedt een compensatoir mechanisme waardoor plaatselijk, met name in de linker kamer en in het septum, een verdikking of hypertrofie ontstaat. Dit kan vervolgens weer leiden tot levensbedreigende ritmestoornissen en plotse hartdood. De therapeutische mogelijkheden zijn bij deze aandoening tot op heden beperkt en de profylactische interventie is met name gericht op het beperken van een progressieve toename van de hypertrofie en het voorkomen van de ritmestoornissen. Dit kan o.a. door middel van een aangepaste levensstijl en door toedienen van medicatie of het plaatsen van een implanteerbare defibrillator (ICD). In geval van geleidingstoornissen kan men het plaatsen van een pacemaker overwegen. Naast deze primaire vorm zijn nog andere oorzaken (secundaire vormen) bekend waardoor een verdikte hartspier of hypertroof hart kan ontstaan bijv. hoge bloeddruk, coronaire vaataandoeningen of zeer intensief sporten (sporthart).

De hoge frequentie van de in de literatuur gerapporteerde mutaties in het B-myosinezware-keten gen $\mathrm{MYH} 7$ was de aanleiding om genetisch onderzoek te starten in een 60-tal erfelijk sterk belaste families (Hoofdstuk 8). Dit hoofdstuk beschrijft de gevolgde strategie om met name ernstig pathogene (maligne) genetische variaties, waarvoor genetisch onderzoek het meest zinvol is, met succes op te sporen. Het protocol is gebaseerd op SSCP-analyse en daaropvolgend sequentie-analyse van de afwijkende SSCP-profielen. De kracht van uitgebreid familie- en koppelingsonderzoek m.b.v. genetische markers en de daaropvolgende succesvolle bepaling van gen en gendefect is beschreven in de daaropvolgende publicatie (8-2). Met koppelingsonderzoek werd het $\alpha$-tropomyosine (TPM1) gen als kandidaatgen aangetoond en vervolgens werd de pathogene mutatie gevonden. Helaas is in veel gevallen het aantal levende patiënten in een familie te klein om succesvol koppelingsonderzoek te verrichten.

In Hoofdstuk 9 wordt de huidige stand van zaken in ons centrum vergeleken met data uit de literatuur en worden een blik op de toekomst geworpen. Concluderend kan worden gesteld dat het genetisch onderzoek van het LQTS heeft geleid tot de identificatie van de oorzakelijke gendefecten bij deze aandoening en een verdere onderverdeling in verschillende subtypen. De duidelijke genotype-fenotype correlatie vereenvoudigt het genetische onderzoek sterk, waardoor snel predictieve diagnostiek op basis van DNA-diagnostiek beschikbaar komt voor de families. Indien nodig, kan direct levensreddende genspecifieke behandeling worden gestart. In geval van HCM heeft het uitgebreide genetisch onderzoek nog niet geleid tot een goede genotypefenotype correlatie. Hierdoor is het momenteel nog niet mogelijk direct het meest 
waarschijnlijke kandidaatgen te selecteren en analyseren. Momenteel heeft het genetisch onderzoek in families met HCM in $30 \%$ een gendefect aangetoond. Predictief onderzoek bij familieleden van de patiënt is opnieuw mogelijk, maar de therapeutische mogelijkheden zijn beperkter dan bij LQTS. Het blijft wel raadzaam om jaarlijks op controle te komen bij de cardioloog om tijdig een (plotse) progressieve toename van de hypertrofie te kunnen waarnemen. Ook kan worden getracht om met behulp van een profylactische behandeling de hypertrofie te vertragen om zodoende langer een voldoende hartfunctie te garanderen.

De laatste jaren heeft het genetisch onderzoek een belangrijke positie ingenomen op het gebied van de cardiovasculaire aandoeningen en het zal in toenemende mate, gezien de snelle technische ontwikkelingen, een belangrijke rol in de differentiaaldiagnostiek gaan vervullen. Met name nu steeds duidelijker wordt dat defecten in dezelfde genen tot verschillende fenotypes kunnen leiden (HCM ofwel gedilateerde cardiomyopathie [DCM]) of dat hetzelfde fenotype wordt veroorzaakt door verschillende genen (tenminste 12 in $\mathrm{HCM}$ ), is het belangrijk om ofwel een goed protocol te kunnen opzetten formuleren ofwel de mutatie detectiecapaciteit enorm uit te breiden. Het eerste kan hopelijk worden bereikt met behulp van gen-expressie profielen van aangedane en niet aangedane weefsels om zodoende een genspecifiek beeld of genprofiel te krijgen en het fenotype te kunnen sub-classificeren. Echter, met name de toegang tot het verkrijgen van het zieke weefsel en de minieme hoeveelheden ervan is een reëel probleem. De tweede optie is in dit opzicht veel belovend en een scala van technieken, zoals bijvoorbeeld mutatiedetectie-CHIPs, kunnen worden toegepast. Men moet zich echter wel realiseren dat de hoeveelheid data die worden gegenereerd niet altijd eenduidig geïnterpreteerd kunnen worden. Voor genetici zal het bepalen van de betekenis van genetisch variatie (ziekteverwekkend of niet) en van de relatie tussen verschillende varianten de grootste uitdaging zijn in de komende jaren. 


\section{Dankwoord}

Het toenmalige hoofd van de afdeling DNA diagnostiek, Henk Meyer, benaderde mij eens met de vraag of ik belangstelling had om te promoveren. Hierdoor werd ik enigszins verrast, maar ik vond, dat ik deze uitdaging niet voorbij mocht laten gaan. Achteraf ben ik blij dat ik destijds het juiste besluit heb genomen en het advies van Henk Meyer en mijn promotor, Joep Geraedts, heb opgevolgd. Beiden wil ik bedanken voor het initiatief en voor het vertrouwen dat ze in mij hebben gesteld. Na het vertrek van Henk Meyer, heeft Bert Smeets zonder aarzelen de taak van eerste co-promotor op zich genomen en ik ben hem zeer dankbaar, dat hij mij steeds met raad en daad en met enorm veel uithoudingsvermogen (waar haalt hij de energie toch vandaan?) heeft gesteund. Dankzij hem, heb ik de moed erin gehouden met name in de laatste fase van het proefschrift.

Verder wil ik in het bijzonder bedanken, Arthur Wilde, hoogleraar Klinische en Experimentele Cardiologie aan de Universiteit van Amsterdam en verbonden aan het Academisch Medisch Centrum te Amsterdam. Arthur Wilde is een van de eerste cardiologen in Nederland die het belang inzag van het in kaart brengen van families met het Long QT syndroom. Naast Arthur Wilde heeft de inzet van Pieter Doevendans, mijn tweede co-promotor, ertoe bijgedragen dat tevens vanuit de cardiologie in Maastricht het aantal te onderzoeken families werd uitgebreid.

Dit proefschrift is in belangrijke mate mogelijk gemaakt door de Stichting Klinische Genetica Zuid-Oost Nederland (SKGZON), in samenwerking met het instituut GROW, het Cardiovasculair Research Instituut Maastricht (CARIM) en het Interuniversitair Cardiologisch Instituut Nederland (ICIN). Hierdoor konden er op het gebied van het Long QT syndroom en de familiaire hypertrofe cardiomyopathie deze resultaten worden behaald.

Het moge duidelijk zijn dat een bijzonder woord van dank op zijn plaats is voor de bijdrage van de afdeling Cardiologie van het AZM en van de klinisch genetici die zijn verbonden aan de klinisch genetische centra in Nederland. Met name de klinisch genetici Irene van Langen (Amsterdam), Peter van Tintelen (Utrecht/Groningen), Carlo Marcelis (Maastricht/Nijmegen) en Paula Helderman (Leiden) hebben ervoor gezorgd dat menige familie het belang van genetisch onderzoek inzag en toestemming heeft gegeven voor het verrichten van DNA onderzoek. Tevens wil ik graag mijn dank uitspreken voor de bijdrage vanuit België met name aan Gert Mathijs en Tom Rossenbacker (Katholieke Universiteit van Leuven) en Christine Verellen (Université Catholique de Louvain, Brussel).

Mijn bijzondere dank gaat uit naar Chantal Conrath. Zij heeft de vele klinische data verwerkt van de gegenotypeerde families. Dankzij haar zijn publicaties tot stand gekomen die een belangrijke bijdrage hebben geleverd aan de genotype-phenotype correlatie bij het Long QT syndroom. Zij zal binnenkort ook haar proefschrift afronden en ik wens haar veel succes bij de verdediging ervan. 
Jan Geelen en Aimée Paulussen waren goede gesprekspartners in de 'ionkanaal discussies' en beiden hebben de karakterisering van een aantal interessante LQT mutaties voor hun rekening genomen.

Voor de prettige samenwerking en morele ondersteuning dank ik vooral mijn labcollega's van het eerste uur, Wil Loots en Diane Merckx, evenals de andere collega's van de DNA diagnostiek, en speciaal Judith Schmeitz-Mulkens, Demis Tserpelis, Crool Velter, Sabine Spiertz en Patricia van Daal, de voormalige HLO studenten Rob Janssen en Stephan Schrooten, de BGK studenten Jelske van der Veen en Kelly Kleinen en de gezellige collega's van de afdeling Populatiegenetica. Ook aan de stafleden van de afdeling DNA diagnostiek voor cardiovasculaire aandoeningen, Arthur van den Wijngaard en Jos Herbergs ben ik veel dank verschuldigd. Beste Francis van der Lubbe, bedankt voor je hulp en deskundigheid. Je was altijd bereid om me te helpen bij het maken van de figuren en posters. Tot slot dank ik mijn paranimfen Frank Kornips en Ger W.R. Fehrenbach voor hun steun op deze, voor mij, zo belangrijke dag. 


\section{Curriculum vitae}

Rosalie Jongbloed werd geboren op 15 maart 1949 te Heerlen.

\section{Gevolgde studies}

1965

1966

1967

1970

1979

1980

1994
M.U.L.O-A, Hoensbroek

Vormingsklas, Hoensbroek

M.U.L.O-B, Brunssum

HBO-A medisch, klinisch chemische studierichting, Laboratoriumschool, Sittard

$\mathrm{HBO}-\mathrm{B}$ biochemische studierichting, Hogere Laboratoriumschool, Oss Stralingshygiene niveau 5B, Universiteit Nijmegen

Stralingshygiene niveau 3, IRS, J.A. Cohen Instituut, Leiden

\section{Werk ervaringen}

1970-1975

1975-1976

1976

1979

1980

1980-1985

1985-2003
Klinisch Chemisch laboratorium, de Wever ziekenhuis, Heerlen Laboratoire Central de Chemie Clinique, Hôpital Cantonal, Lausanne, Zwitserland

Klinisch Chemisch laboratorium, St. Canisius ziekenhuis, Nijmegen Afdeling Biochemische Genetica, Landouw Hogeschool, Wageningen Laboratorium voor weefseltypering, St. Radboud ziekenhuis, Nijmegen Vakgroep Moleculaire Biologie, Universiteit van Nijmegen Capaciteitsgroep Genetica en Celbiologie, Universiteit Maastricht

\section{Additionele werkervaringen}

1994-2003

2000-2001
Lokaal stralingsdeskundige, Stichting Klinische Genetica Zuid-Oost Nederland (SKGZON), Maastricht

Part-time staflid DNA diagnostiek, SKGZON, Maastricht 



\section{Publications}

1. Wehrens X, Rossenbacker T, Jongbloed R, Gewillig M, Heidbüchel H, Doevendans P, Vos M, Wellens $\mathrm{H}$. Heterozygous SCN5A mutation in the domain I-II linker causes Long-OT syndrome with 1:2 atrioventricular block. Hum Mutat. 2003;21:552.

2. Van Langen IM, Birnie E, Alders $M$, Jongbloed RJ, Le Marec $H$, Wilde AAM. The use of genotype-phenotype correlations in mutation analysis for the Long-QT syndrome. J Med Genet. 2003;40:141-145.

3. Jongbloed RJE, Marcelis C, Doevendans P, Schmeitz-Mulkens J, van Dockum WG, Geraedts JPM, Smeets HJM. Variable clinical manifestation of a novel missense mutation in the alpha-Tropomyosin (TPM1) gene in Familial Hypertrophic Cardiomyopathy. J Am Coll Cardiol. 2003;41:981-986.

4. Jongbloed RJE, Doevendans P, Marcelis C, Velter C, Wilde A.A.M, Smeets H.J.M, Geraedts J.P.M. DHPLC Analysis of Potassium Ion Channels in congenital Long-QT syndrome. Hum Mutat. 2002;20:382-391.

5. Conrath CE, Wilde AA, Jongbloed RJ, Alders M, van Langen IM, Peter van Tintelen J, Doevendans PA, Opthof T. Gender differences in the long QT syndrome: effects of beta-adrenoceptor blockade. Cardiovasc Res. 2002;53:770-776.

6. Carrier L, Jongbloed RJE, Smeets HJM, Doevendans PA. Hypertrophic Cardiomyopathy. Cardiovascular Genetics for Clinicians. ed P. Doevendans, A.A.M. Wilde (Dordrecht) Kluwer Academic Publishers. 2001;239:139-154.

7. Jongbloed RJE, van den Bosch BJC, de Coo IFM, Smeets HJM. Mitochondrial Cardiomyopathy. Cardiovascular Genetics for Clinician. Editors; P.Doevendans, A.A.M. Wilde (Dordrecht) Kluwer Academic Publishers. 2001;239:127-138.

8. Jongbloed RJE, Wilde AAM, Geelen JLMC, Doevendans P, Schaap C, Van Langen I, van Tintelen JP, Cobben JM, Beaufort-Krol GCM, Geraedts JPM, Smeets HJM. Novel KCNO1 and HERG missense mutations in Dutch Long-QT families. Hum Mutat. 1999;13:301-310.

9. Wilde AA, Jongbloed RJ, Doevendans PA, Duren DR, Hauer RN, van Langen IM, van Tintelen JP, Smeets HJ, Meyer H, Geelen JH. Auditory stimuli as a trigger for arrhythmic events differentiate HERG-related (LQTS2) patients from KVLQT1-related patients (LOTS1). J Am Coll Cardiol. 1999;33:327-332. 
10. Conrath CE, Jongbloed RJE, van Langen IM, vanTintelen JP, Hauer RNW, Robles de Medina EO, Dürer DR, Hoorntje TM, Lubbers $\amalg$, Doevendans PAFM, Mannens MAMM, Geelen JLMC, Smeets HJM, Wilde AAM. Gene-specific distribution of cardiac events in LQTS1 and LQTS2. Cardiologie. 1999;5:254-259.

11. Geelen JH, Doevendans PA, Jongbloed RJ, Wellens HJ, Geraedts JP. Molecular genetics of inherited long QT syndromes. Eur Heart J. 1998;19:1427-1433.

12. Van den Berg MH, Wilde AA, Robles de Medina EO, Meyer H, Geelen JH, Jongbloed RJ, Wellens HJ, Geraedts JP. The long QT syndrome: a novel missense mutation in the S6 region of the KVLQT1 gene. Hum Genet. 1997;100:356-361.

13. Meijer H, de Graaff E, Merckx DM, Jongbloed RJ, de Die-Smulders CE, Engelen JJ, Fryns JP, Curfs PM, Oostra BA. A deletion of $1.6 \mathrm{~kb}$ proximal to the CGG repeat of the FMR1 gene causes the clinical phenotype of the fragile $X$ syndrome. Hum $\mathrm{Mol}$ Genet. 1994;3:615-620.

14. Meijer H, Jongbloed RJ, Hekking M, Spaapen $\amalg$, Geraedts JP. RFLP haplotyping and mutation analysis of the phenylalanine hydroxylase gene in Dutch phenylketonuria families. Hum Genet. 1993;92:588-592.

15. Meijer H, Hekking M, van den Enden AT, Jongbloed RJ, Schrander-Stumpel CT, Geraedts JP. Phenylketonuria as a model system for DNA diagnosis of hereditary disorders. Ned Tijdschr Geneeskd. 1990;134:1954-1958.

16. Pieters $M H$, Geraedts JP, Meyer H, Dumoulin JC, Evers JL, Jongbloed RJ, Nederlof PM, van der Flier S. Human gametes and zygotes studied by nonradioactive in situ hybridization.Cytogenet Cell Genet. 1990;53:15-19.

17. Hamers AJ, Vaes-Peeters GP, Jongbloed RJ, Millington-Ward AM, Meijer $H$, de DieSmulders CE, Geraedts JP. On the origin of recurrent trisomy 21: determination using chromosomal and DNA polymorphisms. Clin Genet. 1987;32:409-413.

18. Moormann RJ, den Dunnen JT, Heuyerjans J, Jongbloed RJ, van Leen RW, Lubsen $\mathrm{NH}$, Schoenmakers JG. Characterization of the rat gamma-crystallin gene family and its expression in the eye lens. J Mol Biol. 1985;182:419-430.

19. den Dunnen JT, Jongbloed RJ, Geurts van Kessel AH, Schoenmakers JG. Human lens gamma-crystallin sequences are located in the p12-qter region of chromosome 2. Hum Genet. 1985;70:217-221.

20. Moormann RJ, Jongbloed R, Schoenmakers JG. Isolation and characterization of beta- and gamma-crystallin genes from rat genomic cosmid libraries. Gene. 1984 29:1-9. 
21. Schoenmakers JG, den Dunnen JT, Moormann RJ, Jongbloed R, van Leen RW, Lubsen NH. The crystallin gene families. Ciba Found Symp. 1984;106:208-218.

\section{Manuscripts in preparation}

1. Alders M, Jongbloed R, Deelen W, van den Wijngaard A, Doevendans P, Ten Cate F, Regitz-Zagrosek V, Vosberg H, van Langen I, Wilde A, Dooijes D, Mannens M. The 2373insG mutation in the MYBPC3 gene is a founder mutation which accounts for nearly one-fourth of all HCM cases in the Netherlands. Eur Heart J. 2003 (accepted for publication)

2. Jacobs UAM, Jongbloed RJE, Wijburg F, de Klerk JBC, Geraedts JPM, Nijland J, de Coo IFM, Smeets HJM. A novel mtDNA deletion in a patient who died suddenly from Pearson's syndrome after a period of remission. Neuromuscular Disorders. 2003 (submitted)

3. Jongbloed RJE, Schmeitz-Mulkens J, Doevendans PAFM, Tserpelis D, van Langen IM, Marcelis C, van Tintelen PJ, Post JG, Tuerlings JHAM, Wilde AAM, Geraedts JPM, Smeets HJM. Efficient screening of the MYH7 gene in Familial Hypertrophic Cardiomyopathy associated with Sudden Cardiac Death. Am J of Clin Genet, 2003 (submitted).

4. Rossenbacker T, Mubagwa K, Jongbloed RJE, Devriendt K, Vereecke J, Gewillig M, Carmeliet E, Collen D, Heidbüchel H Carmeliet P. A novel mutation in the PAS domain of the $\mathrm{KCNH}_{2}$ gene cauases a malignant form of Long QT syndrome by affecting expression and gating of $\mathrm{KCNH}_{2}$ channels. Circulation 2003 (submitted)

5. Paulussen ADC, Jongbloed RJE, Raes A, Snyders DJ, Cohen N, Smeets HJM, Aerssens J. Characterization of novel mutations E698X and P872fs877 in the C-terminus of the potassium channel (HERG) that causes the long QT syndrome. (submitted).

6. Geelen JLMC, Raes A, Jongbloed RJE, Geraedts JPM, Snyders DJ. Circ Res, Temperature-sensitive rescue of a dominant-negative HERG mutant. (submitted). 
ISBN 90-9017134-7 